Ariane Di Tullio

\title{
A ABORDAGEM PARTICIPATIVA NA CONSTRUÇÃO DE UMA TRILHA INTERPRETATIVA COMO UMA ESTRATÉGIA DE EDUCAÇÃO AMBIENTAL EM SÃO JOSÉ DO RIO PARDO - SP.
}

\author{
Dissertação apresentada à Escola de \\ Engenharia de São Carlos da \\ Universidade de São Paulo, como parte \\ dos requisitos para a obtenção do Título \\ de Mestre em Ciências da Engenharia \\ Ambiental.
}

Orientadora: $\operatorname{Prof}^{\mathrm{a}} \operatorname{Dr}^{\mathrm{a}}$ Haydée Torres de Oliveira 
Ficha catalográfica preparada pela Seção de Tratamento da Informação do Serviço de Biblioteca - EESC/USP

A abordagem participativa na construção de uma trilha interpretativa como uma estratégia de educação ambiental em São José do Rio Pardo-SP / Ariane Di Tullio. -- São Carlos, 2005

Dissertação(Mestrado) -- Escola de Engenharia de São Carlos-Universidade de São Paulo, 2005.

Área: Ciências da Engenharia Ambiental.

Orientadora: Profa. Dra. Haydée Torres de Oliveira.

1. Educação ambiental. 2. Trilha interpretativa. 3. Biodiversidade. 4. São José do Rio Pardo. I. Título. 
Dedico este trabalho a todos os membros da comunidade de São José do Rio Pardo, que com a sua participação, representaram a alma desta pesquisa, em especial à Elisa, Alvinho, Eduardo, Alfredo, Rodrigo P., Rodrigo S., Ana Paula, Marísia, Alex, Danilo, Sandro e Bruno. 



\section{AGRADECIMENTOS}

À minha orientadora, $\operatorname{Prof}^{\mathrm{a}} \operatorname{Dr}^{\mathrm{a}}$ Haydée Torres de Oliveira, pela atenção e amizade a mim dedicadas;

Ao meu pai, Amélio; minha mãe, Leila; e minha irmã, Paula; pelo apoio incondicional em todas as etapas do trabalho, pela ajuda nas filmagens e gravações e, principalmente, pela companhia nas viagens a São José do Rio Pardo;

Às companheiras de trabalho: Maria Alice e Gracinha, pela oportunidade de trabalho conjunto.

Ao Sr. José e à D. Edna, pais da Maria Alice, que me acolheram muitas vezes em sua casa durante as visitas de campo;

A todos os participantes do trabalho, membros da comunidade riopardense;

Ao Sr. Eduardo, administrador da fazenda Tubaca por permitir que o trabalho fosse realizado em sua propriedade;

À diretora da escola municipal, Hellen Rose, e às coordenadoras pedagógicas, Rosemary, Ana Mara e Maria José, por abrirem as portas da escola para que eu pudesse realizar este trabalho;

Ao Luis Roberto e ao Sargento Flávio, pelas informações sobre o município de São José do Rio Pardo, gentilmente cedidas;

Aos colegas do GEPEA, em especial à Carmen, Alessandra, Heloísa, Rosa e Amadeu, pelas diversas oportunidades de trocar idéias e materiais sobre educação ambiental;

À Edna pela ajuda tão gentilmente oferecida na composição do mapa da trilha;

À Prof ${ }^{a} \operatorname{Dr}^{a}$ Ariadne Clöe pela atenção, pelo empréstimo de material e pelas dicas de como usar a técnica de grupos focais;

Às sempre amigas Karina, Gizele e Érica;

Aos Professores Doutores Nivaldo Nale e João Alberto da Silva Sé, integrantes da banca de qualificação, pelas contribuições feitas ao trabalho;

Aos Professores Doutores Nivaldo Nale e Evaldo Gaeta Spíndola, integrantes da banca de defesa, pelas contribuições feitas ao trabalho;

Aos professores, funcionários e colegas do PPG-SEA pela oportunidade e amizade nesses anos de convivência;

À amiga Márcia, com quem pude compartilhar tanto os momentos alegres como os difíceis; e

Ao CNPQ pelo apoio financeiro concedido através da bolsa de estudos. 

São José do Rio Pardo...

$$
\begin{gathered}
\text { Rio Pardo } \\
\text { Pardo } \\
\text { Par... }
\end{gathered}
$$

Par... de quê? De quem?

Do mistério das tuas águas...

Do serpentear do teu caminho?

Que afeto, que carinho

Guardas escondido na tua correnteza

Que enlaça e fere e passa...

$$
\begin{gathered}
\text { Ah! Pardo } \\
\text { Par... }
\end{gathered}
$$

De quê? De quem?

Por que o encanto do céu azul,

O remanso das montanhas que te beijam?

O doce murmúrio da tua água a bater e a desviar-se das pedras do caminho?...

Por que a tua tranqüilidade

Vai acalmando tantas dores,

Tantas vidas

Divididas?

Ah! Pardo

Par do infinito caminhar

Das muitas vidas

De tantas histórias...
A divina luz

Lançou seus raios

Sobre as tuas águas efervecentes...

$$
\text { E agora? }
$$

Todos se encantam contigo

Com tua serenidade macia

E bebendo a tua água...

Tornam-se reféns do teu segredo.

E voltam, e ficam, e amam

$$
\text { E criam filhos }
$$

Sob a tua margem hospitaleira.

Pardo... Pardo... Par...

Do que permanece

Do que não morre...

Do que afaga e não fere?

Ah! Rio Rio Rio Rio

Par do Par do Rio

Rio Par rio do

eterno

singular

meu

Par...

descendo...

impulsionando

renovando

lavando

curando

Rio abençoado

Do viver perene

E do estar transitório... 



\section{RESUMO}

DI TULLIO, A. (2005). A abordagem participativa na construção de uma trilha interpretativa como uma estratégia de educação ambiental em São José do Rio Pardo SP. Dissertação (Mestrado) - Escola de Engenharia de São Carlos, Universidade de São Paulo, São Carlos, 2005.

A indagação central que norteou esta investigação, conduzida no município de São José do Rio Pardo (SP), refere-se à incorporação de abordagens participativas na construção de estratégias educativas contextualizadas e significativas para a comunidade envolvida, criando oportunidades para reflexão, ação e disseminação de idéias e práticas conservacionistas. Assim, esta pesquisa objetivou planejar um processo participativo de desenvolvimento de uma trilha interpretativa como instrumento de educação ambiental, e analisar como a aplicação de metodologias participativas contribui para um maior envolvimento dos participantes nas diversas etapas deste processo. Representantes das Secretarias Municipais de Educação, de Cultura, de Turismo e de Agricultura, assim como Organizações Não Governamentais, empresas e estudantes participaram da pesquisa. Todos envolveram-se, em maior ou menor grau, nas várias etapas de construção da trilha interpretativa: no diagnóstico prévio e escolha do local e do público-alvo; na elaboração do roteiro interpretativo; na realização e avaliação das atividades de visita à trilha por estudantes de ensino fundamental; e na avaliação do processo como um todo. As técnicas utilizadas para coleta de dados no diagnóstico e na construção da trilha foram o diagnóstico rural participativo e os grupos focais, já que com ambas as técnicas é possível lidar com a dimensão interativa de um grupo. A trilha interpretativa tem sido considerada como uma estratégia educativa capaz de transcender os aspectos cognitivos da aprendizagem, proporcionando oportunidades de desenvolvimento dos aspectos afetivos e habilidades dos educandos, podendo, portanto, ser considerada um instrumento efetivo de educação ambiental. Contudo, ela deve ser planejada e considerada como parte de um processo mais amplo e, não, apenas como um evento educativo pontual.A construção da trilha constituiu-se em uma oportunidade de reflexão individual e coletiva a respeito de temas ambientais relevantes. A metodologia participativa possibilita lidar com diferentes níveis de convívio em grupo, como o respeito pelas diferenças, a capacidade de negociação e a tomada de decisões em conjunto. $\mathrm{O}$ interesse inicial pelo tema, as afinidades pessoais e a experiência prévia de trabalho em grupo por parte de alguns dos participantes facilitaram o envolvimento em todas as etapas do projeto. Algumas das dificuldades que podem ser encontradas na continuidade de projetos participativos vão desde a seqüência das atividades - quando a pesquisadora se afasta do grupo - até mudanças no cenário político nos quais estes projetos tenham sido iniciados, o que justifica a importância da participação de representantes também da iniciativa privada e de ONGs. A metodologia participativa, além de gerar uma autonomia dos integrantes do grupo, proporciona maiores possibilidades de continuidade do projeto e possibilita novas iniciativas de ações de conservação e educação ambiental por parte dos envolvidos.

Palavras-chave: educação ambiental, trilha interpretativa, biodiversidade, São José do Rio Pardo. 



\section{ABSTRACT}

DI TULLIO, A. (2005). Participatory approach to creating an interpretive trail as a strategy for environmental education in São José do Rio Pardo - SP. M. Sc. Dissertation - Escola de Engenharia de São Carlos, Universidade de São Paulo, São Carlos, 2005.

The central issue of this investigation, which was conducted in the city of São José do Rio Pardo (SP), is the incorporation of participatory approaches to developing contextualized and significant educational strategies for the community involved, thus creating opportunities for reflection, action and spread of conservationist ideas and practices. This research, therefore, aimed to plan a participatory process of developing an interpretive trail as a tool for environmental education and assess the application of such methodologies in the engagement of the local participants in the different steps of this process. Representatives from the Municipal Departments for Education, Culture, Tourism and Agriculture as well as representatives of Non-Governmental Organizations, companies and students participated in the research. All of them, to a greater or lesser extent, took part in the different steps in the process of creating the interpretive trail: the early diagnosis of the place; the choice of the place and target public; the creation of the interpretive itinerary; the accomplishment and assessment of the activities involved in the visit to the trail made by secondary school students; and the assessment of the process as a whole. Since techniques of participatory rural appraisal and focus groups can provide an interactive dimension of a group, they were used for collecting data from the diagnosis and the development of the trail. Interpretive trail has been shown to be an educational strategy capable of transcending the cognitive aspects of the learning and providing students with opportunities to develop their affective aspects and skills. Thus, it can be considered as an effective tool for environmental education. Nevertheless, it should be first considered as a part of a wider process rather than a prompt educational event. The process consisted of opportunities for individual and collective reflection on the relevant environmental themes. The group life, the respect for differences, and the ability to compromise and make collective decisions were evolved. The initial interest in the theme, the personal affinities, and the previous experience some of the participants had in working group facilitated the engagement, participation and articulation. Some of the difficulties in continuing participatory projects range from the sequence of activities - when the researcher leaves the group - to changes in the political context in which they were initiated. It can explain the importance of the participation of representatives from the private and service sectors. The participatory methodology generates the autonomy of the participants, thus promoting further possibilities for continuing the project and allowing new initiatives for conservationist actions and environmental education from the participants.

Keywords: environmental education, interpretive trail, biodiversity, São José do Rio Pardo. 



\section{LISTA DE FIGURAS}

FIGURA 1 - Localização do município de São José do Rio Pardo no Estado de São Paulo

FIGURA 2 - Distribuição da cobertura vegetal no município de São José do Rio

Pardo

FIGURA 3 - Exemplo do diagrama construído a partir da adaptação das técnicas de diagrama de Venn e diagrama de Fluxos

FIGURA 4 - Diagrama representativo dos principais problemas ambientais encontrados na área rural de São José do Rio Pardo e das relações entre eles

FIGURA 5 - Diagrama representativo dos principais problemas ambientais encontrados na área urbana de São José do Rio Pardo e das relações entre eles

FIGURA 6 - Representação esquemática da trilha da Tubaca e seus pontos interpretativos.

FIGURA 7 - Locais visitados com a finalidade de implantação da trilha interpretativa

FIGURA 8 - Fazenda Tubaca: local escolhido para a implantação da trilha interpretativa

FIGURA 9 - Primeira reunião realizada com os participantes de São José do Rio Pardo

FIGURA 10 - Diagramas construídos pelos participantes referentes aos problemas ambientais locais

FIGURA 11 - Discussões realizadas durante o curso de formação de monitores ambientais

FIGURA 12 - Dinâmicas de grupos realizadas durante o curso de formação de monitores ambientais

FIGURA 13 - Visita à trilha da Tubaca com os participantes do curso de formação de monitores ambientais.

FIGURA 14 - Grupos focais e palestra realizados com os estudantes de ensino fundamental antes da visita à trilha da Tubaca

FIGURA 15 - Cenas da visita à trilha da Tubaca pelos estudantes de ensino fundamental. 

FIGURA 16 - Estudantes de ensino fundamental em visita à trilha da Tubaca........

FIGURA 17 - Atividades realizadas durante a visita dos estudantes à trilha da Tubaca

FIGURA 18 - Grupos focais realizados com os estudantes após a visita à trilha da Tubaca

FIGURA 19 - Avaliação da visita à trilha e do processo da pesquisa, conduzida com os participantes. 



\section{LISTA DE QUADROS}

QUADRO 1 - Evolução da distribuição percentual das classes de uso do solo em São José do Rio Pardo

QUADRO 2 - Temática ambiental veiculada no jornal "A Gazeta do Rio Pardo" nas décadas de 1950 a 1990 ......................................................... 23

QUADRO 3 - Vantagens e desvantagens da técnica de Grupos Focais .................. 32

QUADRO 4 - Categoria de envolvimento no projeto e ocupações dos participantes de São José do Rio Pardo

QUADRO 5 - Potencialidades ambientais municipais em ordem decrescente de importância

QUADRO 6- Principais problemas ambientais em ordem decrescente de importância...................................................................................... 45

QUADRO 7 - Tópico, tema e sub-temas da trilha da Tubaca ............................... 88

QUADRO 8 - Resumo da opinião dos participantes do curso quanto ao seu conteúdo, metodologias e duração ............................................... 97

QUADRO 9 - Contribuições do curso em nível pessoal......................................... 98

QUADRO 10 - Contribuições do curso em nível profissional ................................ 98

QUADRO 11 - Novas oportunidades possibilitadas pelo curso de acordo com os

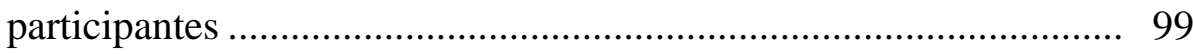





\section{SUMÁRIO}

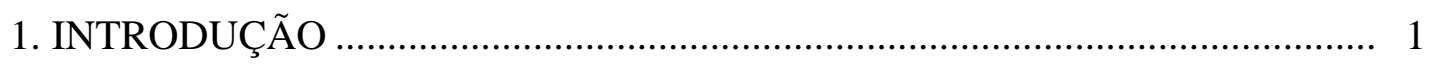

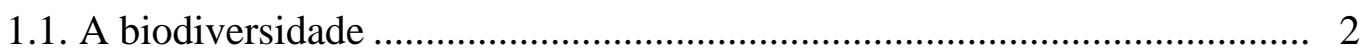

1.2. A conservação de fragmentos florestais................................................... 5

1.3. A pesquisa em educação ambiental......................................................... 7

1.4. A trilha interpretativa como estratégia de educação ambiental .................. 9

1.4.1. Percepção ambiental................................................................... 11

1.4.2. Interpretação ambiental .......................................................... 13

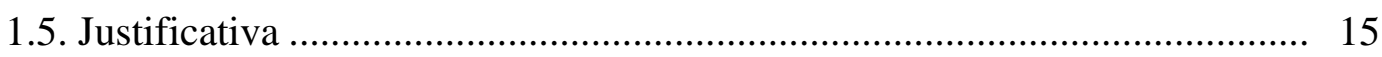

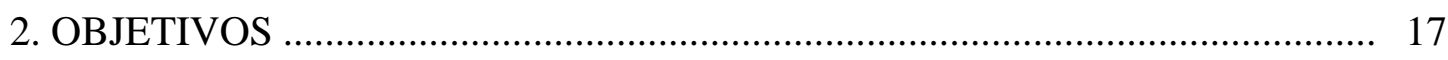

2.1. Objetivos Gerais .................................................................................... 17

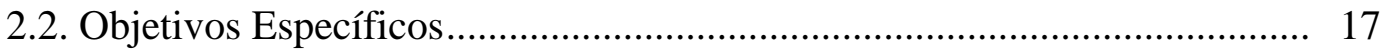

3. CARACTERIZAÇÃO DA ÁREA DE ESTUDO........................................... 19

3.1. Aspectos geográficos, físicos e biológicos............................................... 19

3.2. Histórico de ocupação do município ...................................................... 21

3.3. A temática ambiental na imprensa escrita de São José do Rio Pardo......... 22

3.4. Percepção dos moradores de São José a respeito do Rio Pardo................... 24

4. PROCEDIMENTOS METODOLÓGICOS _..................................................... 25

4.1. Diagnóstico da situação ambiental local ................................................ 27

4.1.1. Diagnóstico participativo das potencialidades e dos problemas ambientais locais $\mathrm{x}$ biodiversidade........................................................... 28

4.2. A construção coletiva da trilha interpretativa do meio ............................... 32

4.3. Avaliação da atividade de visita à trilha da Tubaca e do processo da

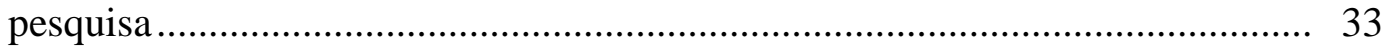

4.3.1. Avaliação conduzida com os estudantes ........................................... 34

4.3.2. Avaliação conduzida com os participantes locais ........................... 35

5. FORMAÇÃO E ATUAÇÃO DO GRUPO DE PARTICIPANTES NAS DIVERSAS ETAPAS DO PROJETO ............................................................. 37 

6. DIAGNÓSTICO DAS POTENCIALIDADES E DOS PROBLEMAS

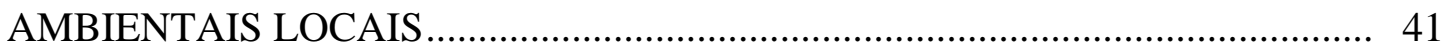

6.1. Biodiversidade: potencialidade e problema! ........................................... 56

7. A CONSTRUÇÃO COLETIVA DA TRILHA INTERPRETATIVA DO MEIO 73

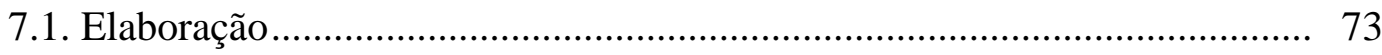

7.1.1. As expectativas dos participantes em relação ao projeto ................... 74

7.1.2. A escolha do local da trilha ............................................................ 77

7.1.2.1. Impactos da construção e do uso de trilhas em áreas naturais 82

7.1.3. Sugestões dos participantes ao roteiro interpretativo........................ 84

7.1.4. A elaboração do roteiro interpretativo .......................................... 87

7.1.5. Primeira revisão do roteiro interpretativo .......................................... 91

7.2. Curso de formação de monitores ambientais ............................................... 94

7.2.1. As expectativas dos participantes do curso ...................................... 95

7.2.2. Avaliaçãa do curso ........................................................................... 96

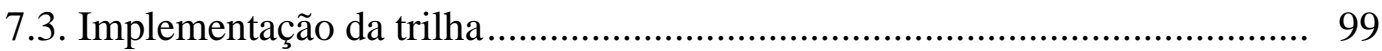

7.4. Avaliação da atividade de visita à trilha e do processo participativo ........... 101

7.4.1. Avaliação da atividade de visita à trilha da Tubaca pelos estudantes. 101

7.4.2. Avaliação da atividade de visita à trilha da Tubaca pelos

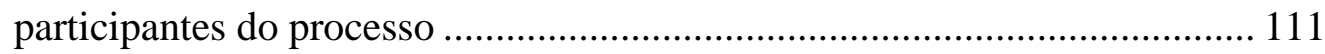

7.4.3. Avaliação do processo da pesquisa pelos participantes locais............ 116

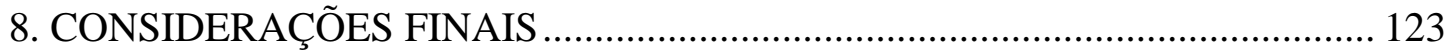

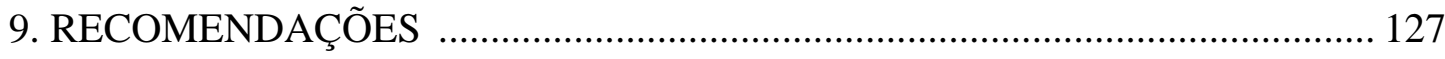

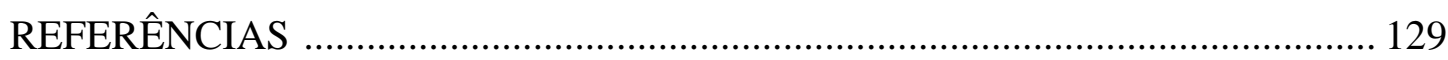

APENNDICE A - Proposta de trabalho apresentada à delegada regional da rede estadual de ensino de São João da Boa Vista - SP ................................................ 137

APÊNDICE B - Roteiro de discussão do grupo focal sobre o tema biodiversidade 138 APÊNDICE C - Carta e proposta de trabalho apresentada aos administradores da

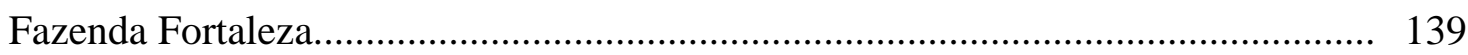



APÊNDICE D - Artigo sobre potencial turístico da fazenda Santa Teresa publicado no jornal Gazeta do Rio Pardo

APÊNDICE E - Roteiro de questões para a primeira revisão do percurso interpretativo da trilha da Tubaca com os participantes.

APÊNDICE F - Roteiro interpretativo para visita guiada à trilha da Tubaca.

APÊNDICE G - Questionário de avaliação do curso de formação de monitores ambientais

APÊNDICE H - Roteiro de questões para a avaliação pré-trilha com os estudantes de ensino fundamental.

APÊNDICE I - Roteiro de questões para a avaliação pós-trilha com os estudantes de ensino fundamental.

APÊNDICE J - Roteiro de questões para a avaliação da atividade de visita à trilha com os participantes

APÊNDICE K - Roteiro de questões para a avaliação do processo da pesquisa com os participantes

ANEXO A - Carta de autorização do projeto elaborada pela delegada regional de ensino e enviada às escolas da rede estadual 159

ANEXO B - Reportagens sobre o projeto publicadas em jornais locais 160

ANEXO C - Indicadores de participação 164 ANEXO D - Fotos 165 



\section{INTRODUÇÃO}

A presente pesquisa, desenvolvida no município de São José do Rio Pardo (SP), está inserida no contexto de um projeto mais amplo: o Biota-Educação Biodiversidade, Sustentabilidade e Educação Ambiental, elaborado em parceria com diversas instituições de ensino superior do Estado de São Paulo, tais como: UNICAMP, ESALQ, UNESP, UFSCar, EESC, entre outras, e cujo objetivo é divulgar às comunidades, os resultados das pesquisas com o tema biodiversidade, realizadas pelos pesquisadores do Programa BIOTA-FAPESP.

A integração entre os pesquisadores das diferentes instituições de ensino envolvidas no projeto só não foi maior devido ao fato deste ainda não ter sido aprovado, até o momento da conclusão dessa pesquisa, pela agência de fomento, o que limitou a divulgação dos resultados, tanto no meio acadêmico, quanto às comunidades.

Esta pesquisa consistiu, ainda, em uma experiência de integração com duas outras, também na área de Educação Ambiental, realizadas na mesma localidade - embora cada uma delas tenha objetivos, indagações e públicos-alvo específicos.

Um dos trabalhos tinha como foco a educação ambiental na gestão dos recursos hídricos em pequenas propriedades rurais. Outro buscava verificar a efetividade da aplicação de uma estratégia de educação ambiental desenvolvida por uma ONG fora de seu contexto de atuação.

A proposta de integração desta pesquisa com os dois trabalhos acima mencionados surgiu da necessidade de somar esforços na geração de conhecimentos e no fortalecimento de ações, visando a conservação da biodiversidade e a gestão dos recursos hídricos locais e regionais. Essa abordagem foi intencional, e buscou, principalmente, desenvolver um trabalho no qual as ações resultantes de sua integração pudessem ser mais efetivas se comparadas às iniciativas individuais e isoladas favorecendo, de maneira enriquecedora, os diversos públicos atingidos, e aumentando 
as chances de mobilização comunitária para ações de proteção ambiental desenvolvidas na região abrangida.

Para isso, o grupo de pesquisadoras utilizou-se de diversas reuniões para o planejamento de integração de suas pesquisas, diagnósticos de estudos sócio-ambientais realizados anteriormente na área, levantamento conjunto de áreas prioritárias para intervenções educativas, além do planejamento de ações educativas integradas, direcionadas a diferentes grupos, tais como: pequenos e médios proprietários rurais, comunidade estudantil, comunidade científica, Organizações Não Governamentais, bem como instituições públicas e privadas.

Assim, a indagação central que norteou a presente investigação refere-se à incorporação de abordagens participativas na construção de estratégias educativas contextualizadas e significativas para a comunidade envolvida num projeto de pesquisa/intervenção em educação ambiental.

Foi proposto, portanto, um processo participativo de construção de uma trilha interpretativa do meio, entendida como uma estratégia de educação ambiental e direcionada a um público específico: estudantes da $6^{a}$ série do Ensino Fundamental. Esta construção envolveu um diagnóstico prévio da situação ambiental local, bem como a elaboração do roteiro interpretativo e a sua implementação com os estudantes. Tanto a pesquisadora como os participantes realizaram uma avaliação do processo reflexivo e colaborativo do projeto.

\subsection{A biodiversidade}

O problema atual da redução do número de espécies e aumento daquelas ameaçadas de extinção no mundo todo é encarado, por muitos autores, como uma crise de biodiversidade. Entende-se por biodiversidade a variabilidade de organismos vivos de todas as origens, compreendendo a totalidade de genes, espécies, ecossistemas e complexos ecológicos. Dentro de um enfoque sistêmico, pode-se dizer que aí se incluem também as populações humanas e sua diversidade cultural (SMA, 1997).

Na história do Planeta Terra, muitas foram as extinções em massa, decorrentes de causas naturais. A mais conhecida delas, no final da era Mesozóica, foi causada por um choque com um grande meteorito, e exterminou grande parte das espécies animais. Atualmente, alega-se que esteja acontecendo uma drástica redução de espécies animais 
e vegetais como conseqüência da degradação ambiental e da destruição de habitats resultantes da expansão das atividades humanas (WILSON, 1997).

No entanto, esta questão da perda da biodiversidade não é um consenso na comunidade científica. Alguns pesquisadores acreditam que ela não pode ser comprovada, já que não se pode quantificar as espécies existente em todo o mundo. Eles ainda afirmam que mesmo que essa redução esteja ocorrendo, não se pode assegurar se suas causas são decorrentes de atividades humanas ou naturais (GAYFORD, 2000).

Apesar dessa discordância, parece existir, entre os autores, um consenso de que a biodiversidade remanescente deve ser, sim, conservada (WILSON, op. cit.; EHRLICH, 1997; MURPHY, 1997; ILTIS, 1997; PLOTKIN, 1997;). Porém, na maioria das vezes, essa convicção de que é importante conservar, está sustentada no uso que os seres humanos podem vir a fazer de espécies que ainda hoje são desconhecidas. Dessa forma, a pesquisa sistemática é considerada essencial para se saber quais espécies estão presentes (sua amplitude geográfica, suas propriedades biológicas, sua vulnerabilidade às mudanças ambientais, entre outros aspectos), já que pouquíssimas delas são conhecidas ou utilizadas. Porém, mais importante do que apenas conhecê-las, é motivar o uso desse conhecimento.

Nota-se que esses autores apresentam uma visão bastante utilitarista do meio ambiente, segundo a qual a biodiversidade deve ser conservada para servir como fonte de riqueza econômica, resolvendo, assim, os problemas ambientais enfrentados na atualidade. Plotkin (op.cit.) defende que há uma perspectiva para novos produtos agrícolas e industriais, tais como plantas medicinais, nos trópicos. $\mathrm{O}$ autor ainda propõe que a solução para a fome nos países pobres seja diversificar a cultura com produtos ainda desconhecidos, retirados das florestas tropicais. O paradoxo consiste em como preservar a biodiversidade nos trópicos se, ainda segundo o mesmo autor, a demanda pela cozinha tropical continua a crescer nos Estados Unidos?

A discordância da comunidade científica em relação à questão da biodiversidade também se manifesta nas questões econômicas, culturais e éticas que permeiam esse tema. Vale ressaltar que a biodiversidade não deve ser encarada apenas em seus aspectos naturais. Deve-se levar também em consideração a diversidade social e cultural das populações humanas que, com o processo atual de globalização, também tendem a ser homogeneizadas.

A proteção da biodiversidade remanescente precisa ser considerada como prioridade no planejamento local, regional, nacional e internacional, devendo ser 
codificada em lei e incorporada na ética e na religião para ser efetiva e duradoura, porque cada cidadão deve desempenhar um papel fundamental nesse processo e não apenas os especialistas (ILTIS, 1997).

Neste sentido, a Convenção sobre Diversidade Biológica (CDB), assinada por 175 países (entre eles, o Brasil) em 05 de junho de 1992, durante a Conferência das Nações Unidas sobre o Meio Ambiente e Desenvolvimento, realizada no Rio de Janeiro, aprovada em 03 de fevereiro de 1994 e promulgada em 16 de março de 1998, tem como objetivos a serem atingidos pelas partes, a conservação e a utilização sustentável da diversidade biológica, bem como a repartição justa e eqüitativa dos benefícios gerados a partir da utilização dos recursos genéticos, através da transferência de tecnologia e financiamento adequado. Cabe às partes contratantes determinar como implementar a CDB através de estratégias, planos ou programas que integrem a conservação e a utilização sustentável da diversidade biológica (MMA, 2000).

Um dos itens previstos na $\mathrm{CDB}$ com finalidade de conservar a biodiversidade remanescente, "in situ", é a criação de um sistema de áreas protegidas que, no Brasil, recebe a denominação de Unidades de Conservação (UCs). Porém, pelo fato dessas unidades estarem isoladas e muitas vezes localizadas em áreas remotas, são insuficientes para enfrentar a crise atual da biodiversidade. Além disso, são escassas e as mudanças climáticas podem dificultar sua manutenção (PETERS e DARLING, 1985 citado por EHRLICH, 1997). Assim, os esforços conservacionistas devem ser feitos também em áreas fora das UCs (CAVALLINI, 2001), em pequenos fragmentos remanescentes de vegetação nativa.

A importância da conservação da biodiversidade não deve ser considerada apenas em florestas tropicais, mas também, em áreas de urbanização. Estas, historicamente, foram as primeiras regiões com grande utilização de espécies selvagens para diversos fins (alimento, uso de peles, controle de predadores), de derrubadas de árvores e introdução de outras espécies, que alteram os ciclos ecológicos locais (caçam as populações nativas, competem com elas e agem como vetores de doenças e parasitas para as quais essas populações são susceptíveis). A destruição de brejos, a poluição do ar e da água também são fontes indiretas de perda de biodiversidade em áreas de urbanização (MURPHY, 1997). 


\subsection{A conservação de fragmentos florestais}

A cobertura florestal, que originalmente ocupava a maior parte do território brasileiro, vem historicamente cedendo espaço para atividades antrópicas, notavelmente a agricultura, a pecuária e a urbanização. Neste cenário, especialmente nas regiões sudeste e sul do país, grandes áreas cobertas no passado por florestas nativas vêm se transformando em paisagens caracterizadas pela fragmentação florestal (SILVA E MARTINS, 2001).

Esse processo não foi diferente com as matas ciliares. Estas envolvem todos os tipos de vegetação arbórea vinculada à beira de rios, independentemente de sua área, região de ocorrência ou composição florística, podendo abranger todo o território brasileiro. A estrutura e a funcionalidade ecossistêmica das matas ciliares apresentam similaridades entre as áreas, mas a composição florística pode apresentar variações inumeráveis e sutis, mesmo em locais de grande proximidade espacial (AB'SABER, 2000).

A primeira legislação que visa a proteger as formações ciliares data de 1965. Porém, segundo Rodrigues e Nave (2000), a inadequação e incoerência das políticas públicas brasileiras, associadas ao descaso do poder público com as questões ambientais, além da quase inexistência de fiscalização, têm resultado na eliminação e conseqüente fragmentação das florestas ciliares ao longo do tempo.

As matas ciliares podem assumir diferentes funções de acordo com os interesses dos diversos setores. Para o pecuarista, por exemplo, elas podem representar um obstáculo ao livre acesso do gado à água; para a produção florestal podem representar espaços bastante produtivos; em regiões de topografia acidentada, podem proporcionar as únicas alternativas para o traçado de estradas; para o abastecimento de água ou geração de energia, representam excelentes locais de armazenamento de água, objetivando garantia de suprimento continuado. Do ponto de vista ecológico, essas áreas têm sido consideradas corredores extremamente importantes para o movimento da fauna ao longo da paisagem, assim como para a dispersão vegetal (LIMA E ZAKIA, 2000).

Apesar da sua inquestionável importância ambiental, as matas ciliares não foram poupadas pelo processo de fragmentação florestal, cuja principal conseqüência é a perda da diversidade animal e vegetal (RODRIGUES E NAVE, op.cit.; VIANNA, TABANEZ e MARTINEZ, 1992). 
Ao longo dos últimos anos, os conservacionistas têm voltado a atenção prioritariamente para os grandes fragmentos, representados pelos parques e reservas protegidas por lei ou para espécies animais ameaçadas de extinção. Muito pouca atenção tem sido dada para a preservação e o manejo de pequenos fragmentos florestais, geralmente localizados em propriedades particulares e normalmente pouco amparados pelas políticas conservacionistas. Estes pequenos fragmentos, em muitos casos, representam a maior parte dos remanescentes de florestas naturais, e conseqüentemente os últimos depositários de biodiversidade (VIANNA, TABANEZ e MARTINEZ, 1992).

Embora essa intensa degradação, associada às questões legais e hídricas, tenha incentivado algumas iniciativas de restauração das florestas ciliares nas últimas décadas, estas geralmente têm como objetivo a proteção de reservatórios de abastecimento público, de geração de energia, e de áreas mineradas. Raramente essa restauração está fundamentada em questões ecológicas, como por exemplo, o restabelecimento de corredores ecológicos, a proteção de populações e ou comunidades, entre outros. Mesmo os projetos de restauração voltados para a melhoria da qualidade ambiental ou paisagística de ambientes antrópicos são poucos, pontuais e isolados (RODRIGUES E NAVE, 2000).

Neste contexto, torna-se inevitável a adoção de técnicas e medidas visando à conservação e recuperação dos fragmentos. Estas dependem do estado de degradação, do tipo e intensidade dos distúrbios e de uma série de características peculiares a cada fragmento, como tamanho, forma, grau de isolamento, natureza do entorno, entre outros. Com a finalidade de obtenção de subsídios para o desenvolvimento de estratégias de conservação e restauração ecológica, é necessário que se faça um diagnóstico do estado de degradação do fragmento, através de estudos florísticos, fitossociológicos e inventários de fauna, comparando-os com fragmentos regionais em melhor estado de conservação (SILVA E MARTINS, 2001).

Os mesmos autores ainda consideram que dentre algumas medidas gerais para conservação e recuperação de fragmentos florestais degradados sejam inclusos: a eliminação do fator de degradação; o enriquecimento destes com espécies tardias localmente extintas; a troca artificial de propágulos entre fragmentos; o aumento no tamanho destes com plantios de espécies nativas; o controle de lianas, gramíneas e outras espécies invasoras; além da implantação de corredores ecológicos, ligando os 
fragmentos e a conscientização da população do entorno para a importância da conservação.

Dessa forma os autores defendem que as intervenções antrópicas em pequenos fragmentos florestais são fundamentais para a conservação e restauração destes, sob pena do processo de empobrecimento da biodiversidade local tornar-se irreversível, levando à grande extinção de espécies vegetais e animais e, até mesmo, ao desaparecimento dos próprios fragmentos.

Sendo assim, a implantação de programas de conservação nessas áreas tem sido um dos maiores desafios de cientistas, gestores públicos, ambientalistas, entre outros; já que eles devem visar a uma maximização da diversidade biológica e não apenas a conservação daquela existente (MURPHY, 1997).

Em seu $13^{\circ}$ artigo, a CDB (MMA, 2000) incentiva o desenvolvimento de programas educacionais que visam a uma compreensão da importância da conservação da biodiversidade e das medidas necessárias a esse fim e da utilização sustentável dos recursos.

Athayde et. al. (2002) defendem que uma das estratégias mais interessantes para a conservação ambiental é promover a formação de pessoas de comunidades para atuarem de forma integrada em várias esferas, fornecendo subsídios para que a própria comunidade possa realizar e sistematizar pesquisas sobre conhecimentos científicos e tradicionais, atuando no resgate, valorização e divulgação destes.

A Educação Ambiental traduz-se, portanto, em um dos esforços de conservação da biodiversidade, já que pode propiciar que uma comunidade reflita sobre os problemas ambientais locais e busque soluções adaptadas ao seu contexto, multiplicando e disseminando idéias e práticas conservacionistas.

\subsection{A pesquisa em educação ambiental}

A pesquisa em educação ambiental baseia-se em diversos paradigmas derivados das correntes da educação. As diferentes abordagens na pesquisa educacional expressam e são expressas por diferentes ideologias (ROBOTTOM e HART, 1993).

A chamada Educação Ambiental (EA) "sobre o meio ambiente" segue uma linha positivista da teoria da educação. A premissa implícita nessa forma de educação é que os problemas ambientais são causados pela falta de conhecimento e que a solução está na difusão da informação. Essa premissa não pode ser considerada totalmente 
verdadeira, já que os países mais contaminados são aqueles nos quais a ciência, a tecnologia e também o sistema educativo estão mais desenvolvidos (MAYER, 1998). Nessa abordagem, é enfatizada a transmissão de informação sobre os elementos dos ecossistemas, suas inter-relações e relações destes com os sistemas sócio-econômicos e culturais. Essa forma de EA costuma se referir a disciplinas como ciências biológicas, geografia e manejo dos recursos naturais, em termos de conteúdo, conceitos ecológicos e de desenvolvimento sustentável (ROBOTTOM e HART, 1993). Essa forma de educação estabelece também uma relação hierárquica de poder, com o educador como centro, o detentor do conhecimento; e os alunos como periferia, receptores do conhecimento (SATO e SANTOS, 1998).

Mayer (op.cit.) cita duas razões pelas quais se acredita que só a informação não é o suficiente para se promover a educação ambiental. A primeira delas é o fato de muitos pesquisadores contestarem a existência de um conhecimento realmente objetivo que represente fielmente o mundo real, sem juízo de valores e interesses. Deve-se garantir, portanto, a pluralidade das informações, ou seja, conhecer diferentes pontos de vista para, então, tomar as decisões oportunas. A segunda razão é que informação não muda atitudes. Há necessidade, para isso, de se criar laços estreitos com o meio ambiente.

Dessas considerações nascem as propostas de "educação no meio ambiente". Essa abordagem educativa reconhece que as atitudes são guiadas muito mais por emoções e valores,que por conhecimentos. Portanto, acredita-se que seja necessário propor experiências que reconstruam a ligação entre o ser humano e o meio ambiente, através de vínculos emocionais (MAYER, op.cit.).

A proposta dessa forma de educação ambiental é tentar envolver o ser humano numa busca por significados e conhecimentos sobre o meio ambiente que o enriqueça tanto como indivíduo quanto como parte de um grupo, refinando continuamente seus valores ambientais. Nesse caso, o meio ambiente constitui um contexto para o aprendizado através de atividades interpretativas, que proporcionam uma experiência direta com o mesmo, desenvolvendo no indivíduo uma empatia com o meio ambiente (na forma de valor e não de habilidade) através da compreensão e dos sentimentos (ROBOTTOM e HART, op.cit.).

Baseada na teoria construtivista da educação, essa abordagem é desenhada através da interpretação, utilizando-se de comparações e contrastes, sendo a compreensão interpretativa fundamentada na interação (SATO e SANTOS, op.cit.). 
O desafio da EA atualmente é englobar o todo: dos valores aos comportamentos, das emoções ao conhecimento, aceitando relações circulares nas quais uns reforçam os outros (MAYER, 1998).

O presente estudo está bastante relacionado a essas duas visões de EA, já que procura levantar informações sobre o meio ambiente junto ao grupo e também proporcionar aos participantes um contato direto com o meio natural. Contudo, procura ir além, na medida em que se volta para uma terceira corrente: a "educação ambiental para o meio ambiente". Nesta, o meio ambiente não deve ser entendido apenas como o natural, distante e preservado, e sim, o ambiente próximo e quotidiano, aquele no qual pequenas iniciativas podem fazer muita diferença (MAYER, op.cit.).

Desenvolvida através da teoria crítica da educação, a principal meta dessa corrente é o desenvolvimento de um compromisso de trabalho (individual e cooperativo) para um meio ambiente melhor, aplicando os conhecimentos e habilidades adquiridas em programas de atuação local, e engajando indivíduos e grupos em processos colaborativos, críticos, de reflexão própria, em situações práticas (ROBOTTOM e HART, 1993).

O enfoque triplo ou complexo da educação ambiental (MAYER, op.cit.) utilizado neste trabalho buscou incorporar as três abordagens acima descritas na prática educativa, por compreender que outras dimensões além da cognitiva, também apresentam fundamental importância na formação do ser humano.

\subsection{A trilha interpretativa como estratégia de educação ambiental}

Com a vida moderna, nos grandes centros urbanos, o contato com o meio ambiente natural é cada vez mais indireto e limitado a ocasiões especiais (TUAN, 1980). A trilha interpretativa constitui-se em um roteiro previamente estabelecido em um sítio natural e/ou artificial, passando por pontos de interesse que podem estar devidamente sinalizados por placas explicativas ou que sejam acompanhados de explicação por parte de um intérprete (CEPA, 2001). Esta estratégia busca despertar nas pessoas uma relação de intimidade com o meio, proporcionando novas sensações e experiências através do contato direto com este. As trilhas interpretativas do meio ambiente têm sido muito difundidas como instrumento de educação ambiental, 
especialmente em áreas preservadas, tais como as unidades de conservação, que buscam aliar ao lazer de seus visitantes, uma prática educativa.

Poucos estudos analisam a validade educacional de uma trilha. Um desses estudos (BRINKER, 1997) considera a trilha ecológica não só como um trajeto a ser percorrido em determinada área do ambiente, mas também, um efetivo instrumento de ensino de ciências biológicas, na medida em que contribui para a compreensão dos fenômenos biológicos e das suas inter-relações. Ela também pode promover atitudes significativas para o desenvolvimento da visão sistêmica e integrada de ambiente. Considera-se ainda (CEPA, 2001) que as trilhas interpretativas constituam uma estratégia utilizada para a promoção de uma maior integração entre o ser humano e o meio natural, proporcionando um melhor conhecimento do ambiente local, dos seus aspectos históricos, geomorfológicos, culturais e naturais.

No entanto, percebe-se que, muitas vezes, o programa desenvolvido resume-se a uma simples difusão de informações técnicas a respeito dos ecossistemas locais. Cabe questionar, portanto, se a trilha interpretativa pode funcionar como um instrumento efetivo de educação ambiental, difundindo conceitos relativos ao meio ambiente natural e sócio-cultural local, criando oportunidade para reflexão e discussão de tópicos relevantes a esse respeito, sensibilizando os visitantes e desenvolvendo a consciência crítica destes. Questiona-se também como a trilha interpretativa do meio deve ser elaborada para que cumpra tal finalidade.

As trilhas como meios de interpretação ambiental não somente visam a transmissão de conhecimentos, como também propiciam atividades que revelam os significados e as características do ambiente por meio do uso de elementos originais, por experiência direta e por meios ilustrativos (TILDEN, 1967). Essa estratégia tem a finalidade de aumentar a percepção de integração do ser humano com a natureza, de modo que o visitante deixe de ser um elemento passivo, que apenas recebe informações, para se transformar num "descobridor" do meio natural (TABANEZ et. al., 1997). Assim, a pessoa tem a oportunidade de tirar suas próprias conclusões a respeito das questões ambientais e de buscar respostas às suas inquietações pessoais, tornando-se, protagonista do seu processo de aprendizagem. Deve-se atentar para o fato de que somente a presença do visitante na trilha não é suficiente para que haja essa sensibilização e reflexão. É necessário que sejam criadas condições para que o visitante perceba os diferentes aspectos do meio ambiente local e os relacione com os demais (BRINKER, op.cit.). Isso pode ser feito através da adequação da linguagem ao público- 
alvo específico e do uso de outros sentidos, além da visão, de forma a perceber o ambiente como um lugar carregado de significados.

Nesse âmbito, as trilhas ecológicas podem funcionar como excelentes instrumentos de EA, pois oferecem contato direto com o ambiente natural, direcionado ao aprendizado e sensibilização, além de propiciar oportunidades de reflexão sobre valores e comportamentos (TABANEZ et al., 1997).

A incorporação dos princípios da percepção e da interpretação ambiental na elaboração da trilha teve como finalidade transcender a simples difusão de informações a respeito dos ecossistemas, e para isso acrescentou-se uma dimensão perceptiva e afetiva ao processo de aprendizagem.

\subsubsection{Percepção ambiental}

Como já dito anteriormente, a questão ambiental atual é muito ampla e não pode ser resumida apenas aos aspectos físico-biológicos do meio ambiente. Muitos indicadores físicos, químicos e biológicos têm sido utilizados para avaliar a qualidade ambiental. No entanto, um dos melhores e menos utilizados, o próprio ser humano, pode perceber as diferentes características do ambiente através de sensações agradáveis ou desagradáveis (CASTELLO, 2001).

A questão básica da percepção do meio ambiente é a tentativa contínua de entender e explicar as complexas inter-relações entre o ser humano e a natureza. Buscase compreender como uma pessoa - seja individualmente, seja como parte de um grupo cultural - percebe o seu entorno e quais decisões e valores estão implícitos ao serem tomadas determinadas atitudes e proposições (OLIVEIRA, 2001).

O centro de interesse da percepção ambiental está na descoberta e na revelação do próprio ser humano, das motivações e dos valores que ditam seus interesses e atitudes. Sem essa auto-compreensão não se pode esperar por soluções duradouras para os problemas ambientais que, em sua essência, são problemas humanos (TUAN, 1980). Ou seja, os valores e interesses que o ser humano carrega desde a antiguidade e que norteiam suas ações são elementos preponderantes da situação global e devem ser inclusos nas pesquisas ambientais.

Os estudos de percepção ambiental são alguns dos resultados do processo de se repensar a relação sujeito-objeto. $O$ foco das pesquisas - que antigamente estava na explicação e na compreensão do objeto de estudo - dá lugar, atualmente, a uma 
abordagem humanista, que implica uma maior atenção aos fenômenos que ocorrem com os sujeitos (inseridos em uma determinada cultura) do que com o objeto externo (GONÇALVES, 1990).

Entende-se que a vivência dos seres humanos com seu ambiente é desenvolvida através da percepção. As sensações que lhes são transmitidas através dos estímulos sensoriais provenientes de seus sistemas de visão, tato, audição, paladar e olfato não ficam restritas a uma percepção unicamente sensorial. A mente humana não se limita a receber passivamente os dados sensoriais, mas os organiza e estrutura, dando-lhes sentidos e significados, através de contribuições ativas do sujeito, como a motivação (MOORE e GOOLEDGE, 1976, FISKE e TAYLOR, 1991 citado por MATAREZI, 2001), o humor, as necessidades, os conhecimentos prévios, os valores, os julgamentos e as expectativas. Nesse sentido, diversos estudos defendem que a mente exerce parte ativa na construção da realidade percebida e, conseqüentemente, na definição da conduta (DEL RIO, 1996 citado por MATAREZI, op.cit.).

As percepções são extremamente pessoais e, além de diferirem com relação às características individuais dos órgãos sensoriais - entre os sexos e entre idades distintas - são influenciadas por experiências e vivências anteriores, aspirações, necessidades, interesses, desejos e valores, normas, costumes e tradições, senso comum, conhecimentos adquiridos e até mesmo antecedentes sócio-econômicos de cada indivíduo (TUAN, 1980).

Dessa forma, os elementos ambientais podem assumir diferentes sentidos segundo o "modo de olhar", ou seja, o modo de atribuir significados de cada indivíduo. É impossível separar o sujeito e o objeto numa paisagem, não apenas porque o objeto espacial é constituído pelo sujeito, mas, também, porque o sujeito está envolvido pela paisagem (OLIVEIRA, 2001). A paisagem, então, pode ser considerada intermediária entre o mundo das coisas e o da subjetividade humana (BARBOSA, 1998; COLLOT, 1990, citado por CABRAL e BUSS, 2001).

Assim, a percepção da paisagem da pessoa que visita uma localidade, freqüentemente é muito diferente daquela do nativo. No nativo, a abordagem se desloca da paisagem como "campo de visibilidade" (caracterizada apenas pelas formas e estrutura visível), para paisagem enquanto "campo de significação" individual e sóciocultural (enfocando os significados e valores construídos pelos sujeitos e grupos que a vivenciam) (CABRAL e BUSS, op. cit.). Enquanto o visitante possui uma percepção 
essencialmente estética do local, o nativo está imerso naquela realidade, apresentando fortes laços afetivos com o lugar (TUAN, 1980).

Dessa forma, há possibilidade de se conhecer os valores mais profundos de uma comunidade, aqueles valores subjetivos que devem ser preservados e difundidos, por constituírem a essência da própria comunidade. Sensibilizar as pessoas no cenário dos seus próprios valores é uma forma de fazer com que eles se tornem muito mais que meros observadores passivos; eles se tornam participantes conscientes de seu papel na sociedade e capazes de ponderar sobre as melhores decisões a serem tomadas (CASTELLO, 2001).

Nesse sentido, o estudo da percepção ambiental como ferramenta na compreensão das intrincadas relações entre o ser humano e o meio ambiente pode trazer contribuições valiosíssimas para a educação ambiental crítica e transformadora, que visa à reflexão sobre atitudes e valores vigentes.

\subsubsection{Interpretação ambiental}

A interpretação ambiental é um enfoque da comunicação que envolve a tradução da linguagem técnica de uma ciência em idéias que possam ser facilmente compreendidas pelo público em geral e de forma interessante (HAM, 1992). O grande desafio do intérprete ambiental é adaptar seus métodos a um público previamente definido. Ainda segundo o mesmo autor, para alcançar o sucesso em atenção e interesse, uma interpretação deve ser amena, leve, além de pertinente, ou seja, deve fazer sentido, ser organizada e conter uma mensagem.

Os seis princípios descritos a seguir resumem a visão de TILDEN (1977) sobre a interpretação:

1- Para ser bem sucedida, a interpretação deve relacionar aquilo que está sendo mostrado ou descrito com aspectos da personalidade, das experiências ou até mesmo dos ideais das pessoas. Essa aproximação do tema a ser interpretado com a realidade pessoal do visitante tem a finalidade de tornar a visita mais interessante e agradável e, segundo Ham (op.cit.), deve ser feita através de exemplos, analogias e comparações.

2- Informação e interpretação não são sinônimos. Embora a informação seja a base da interpretação, esta vai muito além da mera difusão de informação. Através 
da interpretação ambiental, as pessoas devem ser estimuladas a pensar e tirar suas próprias conclusões sobre os assuntos tratados.

3- A interpretação é uma arte que trata os conhecimentos científicos, históricos, arquitetônicos, entre outros, com imaginação, apelo às emoções e ao bem estar físico. Isso se deve ao fato de que, na maioria das vezes, as pessoas estão buscando entretenimento e não instrução.

Assim, o trabalho e os métodos do intérprete são diferentes daqueles utilizados pelo professor em uma sala de aula. As definições extensas e o uso de termos técnicos retirados de livros didáticos poderão fazer com que as pessoas fiquem cansadas e desmotivadas, não se interessando, portanto, pelo tema exposto (HAM, 1992).

4- O objetivo principal da interpretação é a provocação, ou seja, despertar no ouvinte o desejo de ampliar seus horizontes de interesses e conhecimentos. Dessa forma, o visitante poderá construir as suas próprias verdades.

A motivação desse público é a satisfação própria; por isso as pessoas prestarão atenção ao tema abordado mais facilmente se estiverem interessadas e não precisarem de muito esforço para entender o que se expõe. Assim sendo, a interpretação deve possuir um tema bem definido, o que facilita a organização das idéias em uma seqüência lógica (HAM, op.cit.).

5- O objetivo da interpretação deve ser apresentar um todo ao invés da parte. É preferível que o visitante saia com uma ou mais idéias inteiras do que com partes de informação que o deixe com dúvidas a respeito do tema exposto. Através da interpretação, busca-se proporcionar às pessoas a vivência de experiências positivas e enriquecedoras com o local visitado.

6- A interpretação direcionada às crianças não deve ser uma adaptação da apresentação feita para adultos, mas deve seguir uma abordagem fundamentalmente diferente: a grande curiosidade que possuem deve ser levada em consideração na elaboração do roteiro interpretativo. O uso dos sentidos como tato, audição e olfato, além da visão, tem sido recomendado para a observação e exame do ambiente pelas crianças. 
Markwell (1996) questiona muitas práticas atuais de interpretação ambiental por ainda se basearem nos princípios de modelos pedagógicos tradicionais técnicocientíficos, ou seja, aqueles que tendem a enfatizar os aspectos cognitivos da aprendizagem em prejuízo dos afetivos. Essa posição é apoiada na idéia de que o domínio dos conhecimentos e técnicas fornece aos indivíduos fundamentos capazes de sustentar seu compromisso com a conservação. $\mathrm{O}$ autor afirma ainda que se a finalidade do programa interpretativo é o desenvolvimento de um senso ético e responsável de conservação ambiental por parte dos visitantes, devem ser enfatizados ambos os aspectos: cognitivo e afetivo da aprendizagem. Isso significa que, para que a interpretação seja efetiva, ela precisa provocar uma resposta emocional no visitante.

Outra crítica feita aos modelos de interpretação ambiental conhecidos sustenta-se no fato deles terem sido concebidos com base na realidade vivida por países desenvolvidos, devendo assim, ser adaptados aos diferentes contextos dos países em desenvolvimento (HAM, SUTHERLAND e MEGANCK, 1993). No Brasil, por exemplo, onde a maioria das pessoas não tem o costume, o interesse e/ou as condições financeiras para visitar Unidades de Conservação em seus momentos de lazer, os programas interpretativos devem ser desenvolvidos em locais mais próximos e de fácil acesso às comunidades interessadas. Além dos moradores locais, os programas interpretativos também podem ser direcionados a grupos de formadores de opinião e/ou pessoas com influência em âmbito local e/ou regional (pessoas inseridas no poder público, rede de ensino, entre outros). Os temas a serem desenvolvidos também devem possuir certa relevância no contexto local.

Ainda segundo o mesmo autor, esses programas interpretativos podem também assumir funções complementares a programas de ensino formal, de educação de adultos, de grupos civis organizados, entre outros.

\subsection{Justificativa}

A conservação da biodiversidade pode ser considerada um tema de grande relevância em âmbitos nacional, estadual e até mesmo municipal, já que tem sido encontrada como tema prioritário em documentos oficiais dessas três esferas.

Da mesma forma, a educação e a conscientização pública para a compreensão da importância da conservação da biodiversidade vêm sendo inclusas como um aspecto inerente a essa questão. 
Portanto, as pesquisas com o tema biodiversidade são importantes por oferecerem subsídios para a implantação de ações educativas centradas neste tema gerador, especialmente na área escolhida. O município de São José do Rio Pardo carece de iniciativas direcionadas para a conservação e educação ambiental, embora a população local tenha demonstrado interesse pelo assunto. Portanto, trata-se uma área propícia para estudos sobre a referida temática. 


\section{OBJETIVOS}

\subsection{Objetivos Gerais}

- Planejar um processo participativo de construção de uma trilha interpretativa como uma estratégia de educação ambiental;

- Avaliar a utilização de metodologias participativas no processo de engajamento de participantes locais na elaboração, implementação, avaliação de uso da trilha interpretativa e apresentação de propostas para seu uso futuro.

\subsection{Objetivos Específicos}

- Levantar os dados disponíveis de biodiversidade (sejam de diversidade genética, específica, de ecossistemas ou de paisagens e de diversidade sócio-cultural) através de pesquisa em fontes secundárias e do levantamento da percepção dos atores locais a respeito desse tema;

- Planejar a condução do processo participativo de construção e implementação de uma trilha em uma área definida no município de São José do Rio Pardo $\mathrm{SP}$

- Estabelecer um conjunto de indicadores para a avaliação permanente de todas as etapas da criação da trilha interpretativa;

- Construir um instrumento de avaliação de uso da trilha interpretativa por estudantes de ensino fundamental. 



\section{CARACTERIZAÇÃO DA ÁREA DE ESTUDO}

\subsection{Aspectos geográficos, físicos e biológicos}

A pesquisa foi realizada no município de São José do Rio Pardo, localizado na porção alta da bacia do rio Pardo, no estado de São Paulo (Figura 1), com uma superfície de $407 \mathrm{~km}^{2}$ e uma população de cerca de 50.000 habitantes.
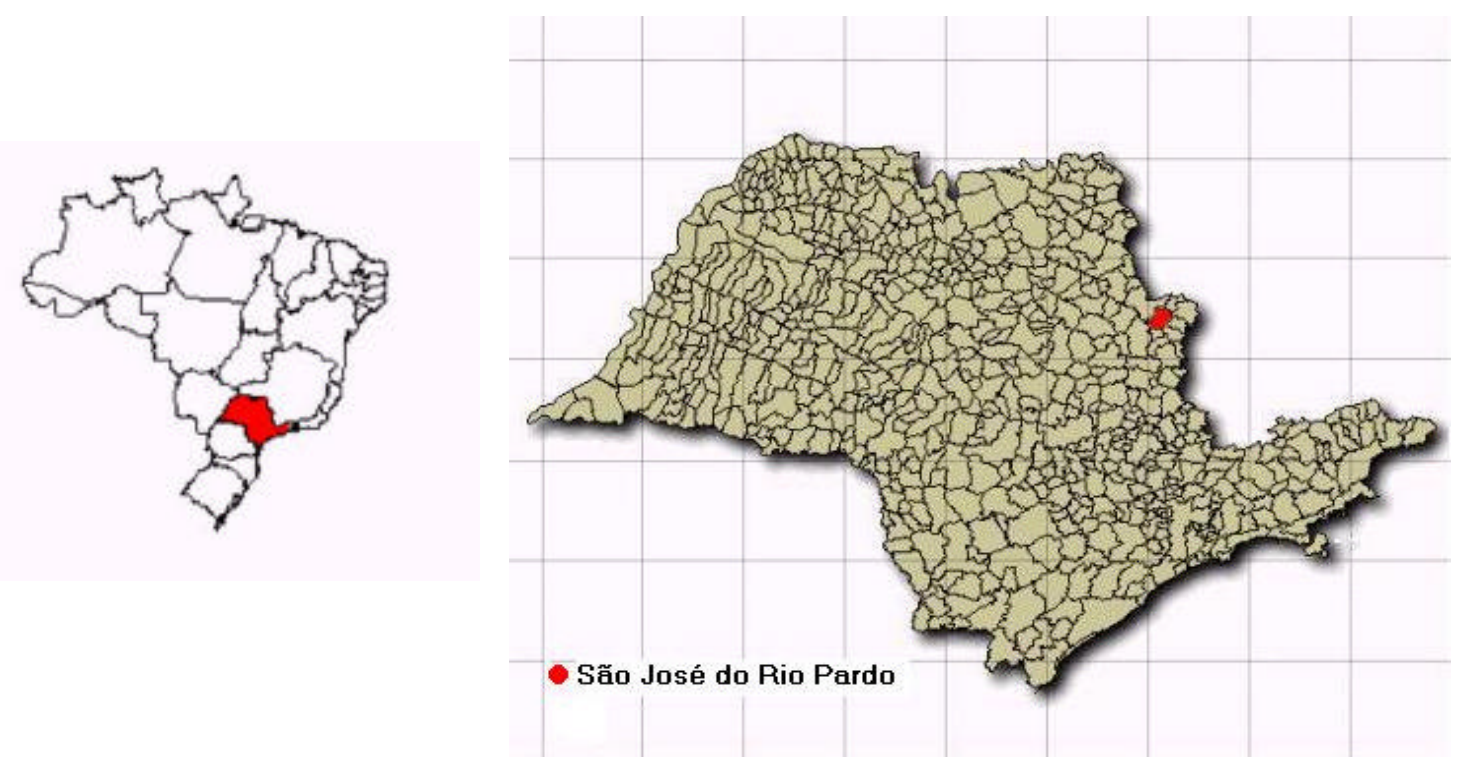

Figura 1 - Localização do município de São José do Rio Pardo, no Estado de São Paulo.

A bacia hidrográfica do rio Pardo situa-se na região sudeste brasileira, abrangendo uma pequena área no planalto sul de Minas (o rio Pardo nasce na Serra do Cervo, município de Itapiúna, MG) e da porção nordeste do estado de São Paulo. O rio Pardo é o maior afluente do rio Grande pela margem esquerda e, apesar de nascer em Minas Gerais, 84\% do seu curso desenvolve-se no estado de São Paulo (IPT, 2001). 
Dos 23 municípios pertencentes à bacia do Pardo, 12 estão contidos integramente na área da bacia e 11 possuem parte de suas áreas em unidades de gerenciamento de recursos hídricos (UGRHIs) adjacentes. Por outro lado, 7 municípios pertencentes a outras UGHRIs têm parte de suas águas na UGRHI 4 (bacia hidrográfica do rio Pardo).

Nesta região as águas drenam o Planalto Ocidental Paulista, onde predomina o sistema de relevo de morros com serras restritas, as serras alongadas e o sistema de relevo mar de morros, todos associados ao embasamento cristalino.

A vegetação nativa encontrada na região de São José do Rio Pardo é a floresta tropical subcaducifólia. Atualmente, porém, devido à ação antrópica, predominam as capoeiras (Figura 2), que representam um estágio arbustivo alto ou florestal baixo na sucessão secundária para floresta, depois do corte, do fogo ou de outros processos predatórios. Do ponto de vista fitofisionômico, caracterizam-se como vegetação secundária, que sucede à derrubada das florestas, constituídas principalmente por indivíduos lenhosos e por espécies espontâneas, que invadem as áreas devastadas, e que exibem porte variável, desde arbustivos até arbóreos, com árvores finas e compactamente dispostas (KRONKA et. al.,1998 citado por IPT, 2001).

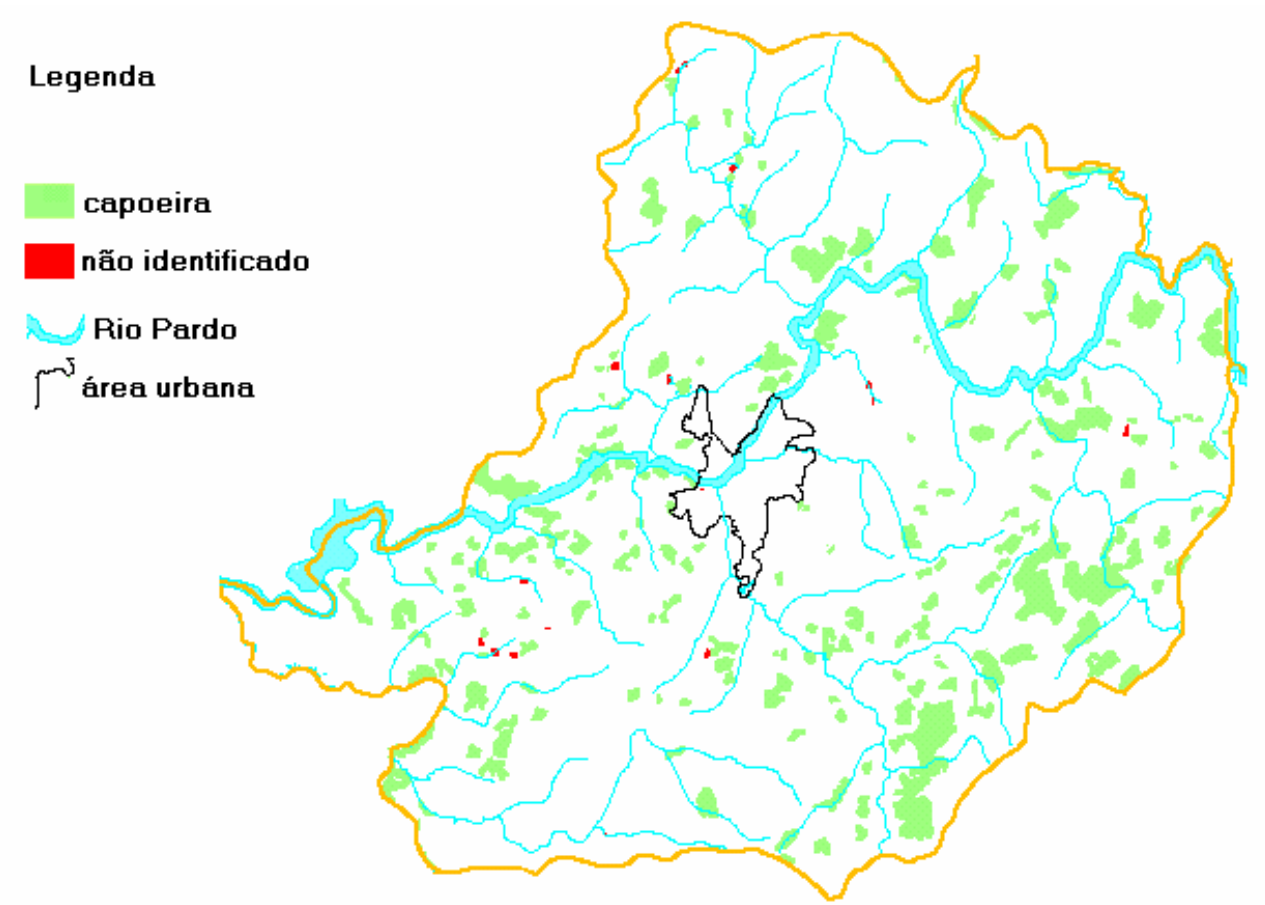

Figura 2 - Distribuição da cobertura vegetal no município de São José do Rio Pardo.

Fonte: IPT (2001) 
Em termos de categorias de uso do solo, na região de São José do Rio Pardo predominam as pastagens e atividades agrícolas, destacando-se os cultivos de braquiária, milho, café e cebola (PINO et. al.,1997 citado por IPT, 2001).

Quadro 1 - Evolução da distribuição percentual das classes de uso do solo, em São José do Rio Pardo.

\begin{tabular}{|c|c|c|c|c|c|c|c|c|c|c|c|c|}
\hline \multicolumn{3}{|c|}{ Vegetação natural } & \multicolumn{3}{|c|}{ Reflorestamento } & \multicolumn{3}{c|}{ Pastagens } & \multicolumn{3}{c|}{ Agrícola } & Urbana \\
\hline 1980 & 1985 & 1997 & 1980 & 1985 & 1997 & 1980 & 1985 & 1997 & 1980 & 1985 & 1997 & 1997 \\
\hline 9,0 & 8,4 & 2,67 & 1,0 & 1,0 & 0,0 & 54 & 51,6 & 61,88 & 36 & 38 & 33,16 & 2,30 \\
\hline
\end{tabular}

Fonte: SMA 1995 citado por IPT, 2001.

A partir do Quadro 1, verifica-se que, nas últimas décadas, a principal alteração ocorrida no município, com relação ao uso do solo, foi um aumento significativo nas áreas de pastagens em função da diminuição das áreas de vegetação natural e do declínio das áreas de atividades agrícolas.

\subsection{Histórico de ocupação do município ${ }^{1}$}

A ocupação da região se deu especialmente a partir da decadência da mineração no Estado de Minas Gerais. Pecuaristas vindos da região da Mantiqueira chegaram à região em busca de novas oportunidades nas terras férteis do planalto paulista. Serviu também de pouso aos tropeiros e bandeirantes que se deslocavam em direção às minas de ouro de Goiás. Um dos primeiros moradores de São José do Rio Pardo chegou em 1866, vindo de São João Del Rei, Minas Gerais.

O crescimento da vila tomou impulso com a chegada dos imigrantes (italianos, portugueses, japoneses, austríacos, etc.) que trabalharam tanto nos cafezais como na instalação do comércio, dos bancos e de pequenas fábricas, além de influenciarem na vida social e cultural.

O café, vindo do Rio de Janeiro no século XIX, chegou ao Estado de São Paulo através do Vale do Paraíba, expandindo-se pelo interior do Estado, onde se intensificou na segunda metade do século XIX. Seu cultivo chegou à região antes dos meios de transporte, cuja produção se destaca a partir de 1886, atingindo seu apogeu por volta de 1920, após a chegada dos imigrantes. Nesse processo de ocupação, a atividade cafeeira exerceu grande influência no crescimento demográfico e econômico nas regiões por

\footnotetext{
${ }^{1}$ Fonte: Del Guerra (1999).
} 
onde passou no território paulista. Além disso, provocou alterações ambientais - como a degradação do solo e os processos erosivos instalados após o abandono das áreas - e, conseqüentemente, impactos nos recursos hídricos.

Destaca-se, também, a instalação das ferrovias como fator de influência ao desenvolvimento da região, tanto do ponto de vista econômico quanto urbano. A estrada de ferro instalou-se a serviço dos fazendeiros, acompanhando o progresso das zonas cafeeiras.

Na Bacia do Pardo, a decadência do café não ocasionou o abandono das terras, mas sua divisão em pequenas e médias propriedades e a introdução de novas culturas, como a citricultura, o algodão, a cana de açúcar, a pecuária e, posteriormente, a instalação da indústria.

A história de São José do Rio Pardo está bastante ligada à história do Brasil, porque foi o primeiro lugar do país a romper os laços com a monarquia antes da proclamação da república. Os republicanos locais tomaram a Câmara Municipal, prenderam seu presidente e assim foi proclamada a República na Vila de São José do Rio Pardo!

Uma característica importante de São José do Rio Pardo é a produção cultural única, ao redor do escritor Euclides da Cunha, que viveu na cidade durante a reconstrução da ponte que leva seu nome e enquanto escrevia sua obra mais conhecida, “Os Sertões" (1902).

\subsection{A temática ambiental na imprensa escrita de São José do Rio Pardo}

O Quadro 2 resume os resultados da análise da temática ambiental veiculadas no principal jornal local de São José do Rio Pardo (Gazeta do Rio Pardo), realizada por Ferreira (2001).

Verifica-se que na década de 1950, a relação do ser humano com o meio ambiente era abordada de forma antropocêntrica e utilitarista. A preservação dos ecossistemas era vista como uma forma de garantir sua utilização como fonte de matéria-prima, ou de lazer e contemplação.

Nas décadas de 1960 e 1970, houve uma grande restrição ao tratamento da temática ambiental no jornal. Esta voltou a ser veiculada nos anos 1980, tendo seu ápice, na década de 1990. 
Foram encontrados artigos relacionados a mortes por afogamento ou suicídio no rio Pardo, nas décadas de 1960, 1970 e 1980. O rio muitas vezes foi responsabilizado por tais mortes.

Quadro 2: Temática ambiental veiculada no jornal “A Gazeta do Rio Pardo” nas décadas de 1950 a 1990.

\begin{tabular}{|c|c|c|}
\hline $\begin{array}{l}\text { Temas } \backslash \\
\text { Décadas }\end{array}$ & 1950 & 1960-1990 \\
\hline Solo & $\begin{array}{l}\text { Desgaste e erosão. Apelo ao respeito à } \\
\text { legislação para que não perdesse a } \\
\text { fertilidade. }\end{array}$ & \\
\hline Flora & $\begin{array}{l}\text { Presença de matas ciliares ao longo do rio } \\
\text { Pardo. } \\
\text { Destruição de áreas verdes. }\end{array}$ & $\begin{array}{l}\text { Importância da vegetação com ênfase na sua } \\
\text { utilidade pelos seres humanos. } \\
\text { Campanhas de arborização realizadas pela } \\
\text { prefeitura. }\end{array}$ \\
\hline Fauna & $\begin{array}{l}\text { Caça comum e abusiva, conservação para } \\
\text { perpetuação do esporte. }\end{array}$ & \\
\hline Água & $\begin{array}{l}\text { Reforma e ampliação do serviço de } \\
\text { abastecimento. }\end{array}$ & $\begin{array}{l}\text { Necessidade de atuação da população junto } \\
\text { com o poder público para enfrentar a } \\
\text { escassez. }\end{array}$ \\
\hline Clima & $\begin{array}{l}\text { Desequilíbrios climáticos com conseqüências } \\
\text { para as práticas agrícolas. }\end{array}$ & $\begin{array}{l}\text { Desequilíbrios climáticos com conseqüências } \\
\text { para as práticas agrícolas. Alguns discutiam } \\
\text { as causas das enchentes. }\end{array}$ \\
\hline Energia & $\begin{array}{l}\text { Necessidade de aproveitamento de diversas } \\
\text { fontes de energia, tais como hidrelétrica e } \\
\text { solar. }\end{array}$ & $\begin{array}{l}\text { Construção de hidrelétricas em São José do } \\
\text { Rio Pardo não solucionou os problemas } \\
\text { relacionados à crise energética. Anos } 1990 \text { - } \\
\text { possibilidade de construção de novas } \\
\text { hidrelétricas, dessa vez, com a discussão dos } \\
\text { seus impactos negativos. }\end{array}$ \\
\hline
\end{tabular}

Na década de 1980, começa a se perceber uma admiração do povo riopardense pelo rio Pardo, não só pela sua utilização, mas também pela sua importância, não mais vinculada apenas à necessidade de servir aos seres humanos. Também a partir dessa época, percebe-se um menor contato da população com o rio devido à poluição e à alteração da ictiofauna. 


\subsection{Percepção dos moradores de São José a respeito do rio Pardo}

Um diagnóstico da percepção de alunos de $8^{\mathrm{a}}$ série com relação ao rio Pardo, realizado anteriormente (FERREIRA e OLIVEIRA, 2001), mostra que há uma enorme deficiência de informação quanto aos aspectos ecológicos, físicos, geográficos, área de influência e importância histórica do rio Pardo. Observa-se que eles têm uma imagem negativa do rio Pardo, fato que está estreitamente relacionado aos problemas enfrentados pela população, que não acredita que serão resolvidos, e/ou não sabe como fazê-lo.

Aliada a essa falta de informações, Ferreira (2001) detectou ainda, através de entrevistas com antigos moradores do entorno do rio Pardo, uma percepção de perda da biodiversidade local ao longo das últimas cinco décadas.

Dessa forma, percebe-se a necessidade de se desenvolver uma estratégia educativa que conscientize e sensibilize a população, no sentido de refletir sobre a importância da bacia hidrográfica do rio Pardo na conservação da biodiversidade, na história, na economia e na cultura local. 


\section{PROCEDIMENTOS METODOLÓGICOS}

A abordagem qualitativa escolhida para este trabalho é a que envolve a obtenção de dados descritivos, através do contato direto do pesquisador com a situação estudada, enfatizando mais o processo do que o produto, e se preocupando em retratar a perspectiva dos participantes (BOGDAN E BIKLEN, 1982 citado por LUDKE E ANDRÉ, 1986). A finalidade real da pesquisa qualitativa não é quantificar opiniões, e sim explorar a variedade delas num grupo (GASKELL, 2003).

Ao longo da história da humanidade, os grupos que detinham o poder e o saber definiam o que deveria ser pesquisado, quando deveria ser pesquisado e para quem serviriam essas pesquisas, de forma que os grupos pesquisados comportavam-se como meros objetos da pesquisa feita "sobre" eles e não "com" eles (OLIVEIRA e OLIVEIRA, 1981). Dessa forma, os resultados dessas pesquisas, muitas vezes sem aplicação prática, eram inacessíveis às pessoas em geral.

Felizmente, nos últimos anos, os conceitos de neutralidade, objetividade e rigor científico começaram a ser questionados e entendidos como parte de uma tradição positivista, não mais tida como única possibilidade para se fazer ciência. Começam a ser realizados, então, estudos da realidade social com objetivos mais úteis às comunidades estudadas. O pesquisador passa a assumir uma dupla postura, tanto de observador crítico, como de participante ativo, desenvolvendo relações horizontais e antiautoritárias com os participantes da pesquisa (OLIVEIRA E OLIVEIRA, op.cit.).

Gajardo (1986) acredita que na América Latina a pesquisa participante não tenha uma identidade única, assumindo diferentes alcances e significados derivados das diversas tradições de pensamento e práticas atribuídas a esse tipo de atividade. A mesma autora identifica ainda três enfoques que consideram a pesquisa como um processo aberto à participação de setores populares na criação e no desenvolvimento de programas de ação social e educacional: a pesquisa ativa, a pesquisa na ação e a pesquisa participante. Embora em todas elas exista um componente educacional, elas 
diferem quanto aos grupos de implementação bem como ao tipo de participação que se espera desses grupos. A pesquisa participante é a única que propõe a participação dos sujeitos ao longo do processo, ou seja, o tema pode ser proposto tanto pelo grupo como pelos pesquisadores.

A Educação Ambiental participativa envolve o grupo na identificação de tópicos de relevância e interesse, reuniões colaborativas, análise dos dados de acordo com o contexto, e divulgação dos resultados. A geração de conhecimentos é sempre mediada pela reflexão crítica e a questão metodológica que se coloca é: como assegurar que o foco das questões de pesquisa seja do interesse dos participantes (ROBOTTOM e SAUVÉ, 2003).

Dessa forma, no presente trabalho, buscou-se envolver os participantes locais no maior número possível de fases do processo: no levantamento inicial da biodiversidade, na elaboração da trilha, na sua implementação, bem como na avaliação do processo e nas propostas para a sua continuidade.

Entendida por muitos autores como um tipo de pesquisa participativa orientada em função da resolução de problemas coletivos ou de objetivos de transformação, a pesquisa-ação supõe uma forma de ação planejada (que mereça investigação para ser elaborada e conduzida), de caráter social, educacional, técnico ou outro (THIOLLENT, 2000).

A questão metodológica da participação do grupo local, neste trabalho, está em pensar e construir "com eles" e "para eles" uma ação educativa, que, no caso, constituise na elaboração, implantação e avaliação de uma trilha interpretativa do meio que funcione como um instrumento de Educação Ambiental. A primeira etapa consiste na identificação das motivações dos participantes em se envolver no trabalho, das suas preocupações com relação ao meio ambiente local e das potencialidades do município em termos de biodiversidade.

Thiollent (op.cit.) acredita que a pesquisa-ação deva enfatizar um de três aspectos: a resolução de problemas, a tomada de consciência ou a produção de conhecimento. Note-se que a produção de conhecimento é o objetivo de toda pesquisa científica, e especificamente desta, caracteriza-se como objetivo teórico. Já o objetivo prático deste trabalho é tornar mais evidente aos olhos dos interessados a natureza e a complexidade das questões ambientais consideradas, especialmente no que se refere ao tema biodiversidade. 
Definida como um método (ou uma estratégia de pesquisa) a pesquisa-ação lança mão de diversos métodos ou técnicas em cada fase do processo de investigação (coleta e interpretação dos dados, organização de ações, registro dos dados, exposição dos resultados) para lidar com a dimensão coletiva e interativa do grupo (THIOLLENT, 2000).

Os métodos e as técnicas utilizados devem possibilitar a participação dos grupos envolvidos na descoberta e transformação da sua própria realidade. Assim, o levantamento de dados e a organização da informação contemplam o uso de técnicas e instrumentos próprios das ciências sociais, tais como questionários, observação participante, aplicação de pautas de entrevistas estruturadas ou semi-estruturadas, guias e diários de campo, e as técnicas mais difundidas são aquelas que permitem registrar as dimensões qualitativas dos processos sociais e educacionais (GAJARDO, 1986).

$\mathrm{O}$ presente trabalho divide-se em duas etapas. A primeira consiste em um levantamento da diversidade biológica e sócio-cultural local, feito em fontes secundárias, e em relação à percepção do grupo sobre o tema. A segunda consiste na intervenção educativa propriamente dita: a elaboração, implementação e avaliação participativa da trilha interpretativa.

\subsection{Diagnóstico da situação ambiental local}

O objetivo dessa primeira etapa foi identificar temas ambientais (problemas e potencialidades) que se mostraram mais relevantes no contexto local, buscando compreender as relações entre eles. Num segundo momento, buscou-se aprofundar a discussão em torno do tema "biodiversidade", considerado um tema relevante, tanto pela pesquisadora quanto pelos integrantes do grupo envolvido no trabalho. Esse diagnóstico teve como finalidade subsidiar a intervenção educativa e foi realizado por meio de análise documental e de um diagnóstico participativo.

\section{Análise Documental}

Essa etapa consistiu em um levantamento de dados secundários locais. Poucos relatórios e documentos resultantes de pesquisas realizadas no local foram encontrados. Algumas das fontes utilizadas neste trabalho foram: Relatório Zero do Comitê de Bacia Hidrográfica do Pardo, dados do Instituto Brasileiro de Geografia e Estatística (IBGE), Fundação Sistema Estadual de Análise de Dados (SEADE), bem como uma dissertação 
(FERREIRA, 2001) e uma monografia de conclusão de curso (BOZZINI, 1996) desenvolvidas no local. Alguns desses dados estão localizados no capítulo referente à caracterização da área de estudo, e outros embasam as discussões feitas nos capítulos referentes aos resultados da presente pesquisa.

\section{Diagnóstico Participativo}

O diagnóstico participativo teve como finalidade identificar os temas ambientais mais relevantes segundo a percepção dos participantes locais, bem como aprofundar a discussão em torno do tema biodiversidade. Para tanto, foram utilizadas duas técnicas: o diagnóstico rural participativo (DRP) e os grupos focais, respectivamente.

\subsubsection{Diagnóstico participativo das potencialidades e dos problemas ambientais locais $\mathbf{x}$ biodiversidade}

Através desse diagnóstico buscou-se compreender a percepção que a comunidade possui dos temas ambientais mais relevantes no contexto local, bem como das relações entre eles. A técnica utilizada para tanto foi o Diagnóstico Rural Participativo (DRP). Muitos dos problemas e das potencialidades levantadas pelos participantes do processo foram inclusos no roteiro das atividades da trilha, sendo, portanto, abordados em fases posteriores do trabalho.

Nota-se que muitos dos projetos de educação ambiental desenvolvidos atualmente, se não a maioria, lidam apenas com a dimensão de problemas do meio ambiente. No entanto, a educação ambiental é mais ampla e complexa do que uma simples ferramenta para a resolução de problemas ambientais e mudança de comportamento. Neste trabalho, também foram incorporadas ao processo as potencialidades ambientais como forma de acrescentar outras dimensões, tais como a estética, a apreciação, o respeito e o envolvimento com relação à questão ambiental (SAUVÉ, 2003).

\section{Diagnóstico Rural Participativo (DRP)}

Os métodos de diagnósticos rurais participativos começaram a se desenvolver na década de 1970, em torno de uma abordagem conhecida como Diagnóstico Rápido de Sistemas Rurais (DRSR), que teve suas origens nas Ciências Agrárias, estimulada por 
uma necessidade de melhorar a compreensão a respeito da realidade vivida pela população rural, a fim de planejar melhor suas intervenções na área e a formulação de projetos de desenvolvimento (CONWAY, 1993 citado por FARIA, 2000).

Dessa forma, o DRP recebeu influências de outros métodos utilizados em Ciências Agrárias, tais como o FSR/E (do inglês, Pesquisa e Extensão em Sistemas Agrícolas), que incorporou a idéia de incluir a visão do produtor na pesquisa agrícola; a $\mathrm{AAE}$ (Análise de Agroecossistemas), que contribuiu com os diagramas, técnicas e ferramentas (FARIA, op.cit.), tais como o mapa mental; o diagrama de Venn, o diagrama de fluxos, a matriz, o calendário sazonal, entre outros; o DRR (Diagnóstico Rápido Rural), que lança mão de uma gama de ferramentas para avaliar uma situação, um tópico ou um problema. Através do DRR, a população local participa da geração dos dados e das discussões acerca dos resultados, porém não é inclusa no processo de análise de informações (CORWALL et. al., 1993 citado por FARIA, op.cit.).

O DRP traz uma ênfase na participação da população na análise das informações e planejamento das ações, iniciando um processo de fortalecimento da capacidade de movimento e articulação da população, de forma que esta possa modificar suas condições de vida, permitindo-se desenvolver sua própria interpretação sobre a realidade, seguida de um planejamento e de uma ação coletiva (CHAMBERS, 1994).

O DRP também é considerado por muitos autores um método em construção (CHAMBERS, 1995; CORWALL et. al., 1993; MEYER, 1997 citado por FARIA, op.cit.) e, por esse motivo, ainda recebe influências de outras correntes, tais como da antropologia aplicada e da pesquisa-ação participativa.

Segundo Doyle e Krasny (2003), citando Chambers (1999) e Webbe e Ison (1994), o DRP pode ser considerado um tipo de pesquisa-ação participativa utilizado para engajar grupos economicamente ou socialmente marginalizados na identificação de problemas locais, com a finalidade de promover uma ação.

Muitos pesquisadores têm adaptado os métodos do DRP para uso em comunidades urbanas de países em desenvolvimento. Em 2000, a Universidade Cornell e a Cooperativa Cornell de Extensão de Educadores de Nova York iniciaram o programa "Garden Mosaics", no qual os educadores da comunidade adaptariam as ferramentas de pesquisa e as abordagens do DRP para uso em um programa de Educação Ambiental com comunidades urbanas. Os resultados desse estudo indicam o potencial de uso do DRP nesses programas, pois as atividades utilizadas envolveram e promoveram interações positivas entre os públicos pesquisados. 
No presente trabalho, foi feita uma adaptação das técnicas de diagrama de Venn e diagrama de Fluxos (FERREIRA NETO, 2004), de forma que pudéssemos, além de conhecer os principais problemas e potencialidades do município, identificar suas magnitudes e as relações entre eles (causas e consequiências), bem como a quem competiria a solução destes problemas

O diagrama de Venn consiste em identificar e listar os itens a serem analisados, que neste caso são os problemas e as potencialidades, por ordem de importância, representando-os por meio de círculos de tamanhos variados. Assim, o problema considerado mais grave e a potencialidade mais relevante foram representados pelos círculos de maior tamanho. Da mesma forma, o problema menos grave e a potencialidade menos relevante foram representados pelos círculos menores. Problemas e potencialidades de importância intermediária entre esses dois extremos foram representados por círculos também de tamanhos intermediários. O diagrama de Fluxos consiste no estabelecimento de relações de causa e conseqüência entre os itens analisados, por meio da colocação de setas entre eles.

A Figura 3 apresenta um exemplo da adaptação das duas técnicas descritas. As situações levantadas pelos participantes são representadas por círculos cujos tamanhos aparecem em ordem decrescente de relevância. As setas representam as relações de causa e efeito entre eles.

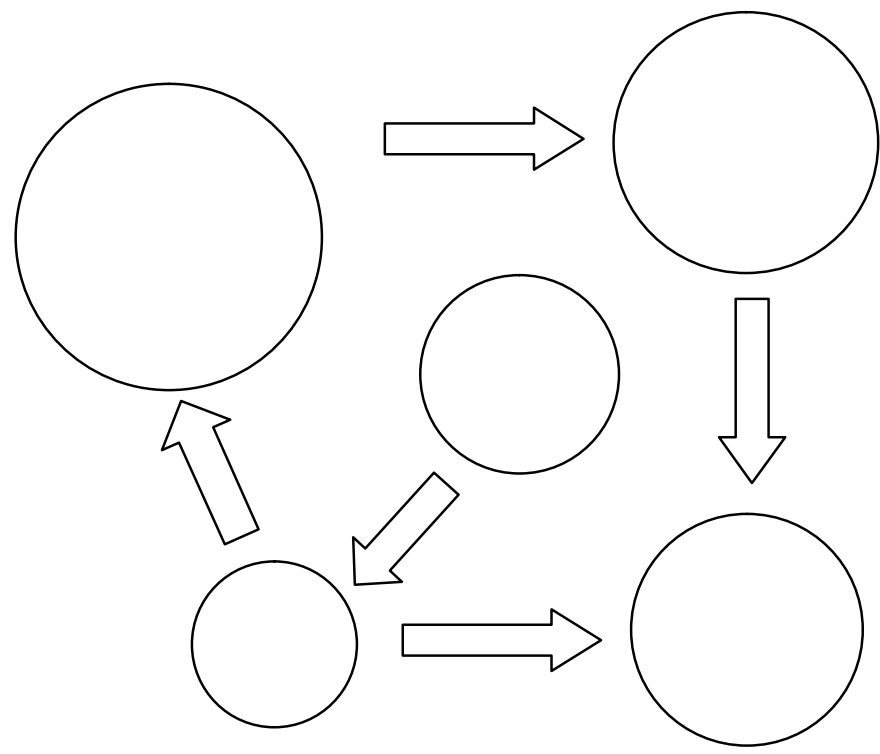

FIGURA 3 - Exemplo do diagrama construído a partir da adaptação das técnicas de diagrama de Venn e diagrama de Fluxos. 
Os materiais utilizados para a confecção dos diagramas consistiram em cartolinas recortadas em forma de círculos de diferentes tamanhos e setas, bem como canetas coloridas. Esse tipo de material facilita a aplicação da técnica, já que permite a mobilidade necessária para o grupo testar várias combinações, tanto de importância quanto de inter-relações entre os diversos elementos, antes de chegar a um consenso sobre o diagrama final.

Os dados geralmente são registrados por um ou dois relatores, que fazem anotações a respeito dos principais pontos discutidos durante a atividade para posterior análise. Neste trabalho, as discussões foram registradas em fita cassete e VHS, e posteriormente transcritas e analisadas.

Após o levantamento dos principais problemas e potencialidades ambientais locais, foi utilizada a técnica de grupos focais para aprofundar as discussões em um dos temas considerados relevantes: a biodiversidade.

\section{Grupos Focais}

A técnica de grupos focais, também entendida como uma entrevista coletiva, consiste em uma entrevista semi-estruturada com um grupo de respondentes, buscando a compreensão das visões de mundo dos entrevistados através da interação, da troca de idéias e de significados, em que várias percepções são exploradas e desenvolvidas (GASKELL, 2003). É uma técnica considerada ideal para se explorar experiências, opiniões, desejos, além de permitir que os participantes gerem suas próprias questões, conceitos e prioridades. Eles devem ser encorajados a explorar essas questões, identificar problemas comuns e sugerir potenciais soluções através de experiências comparadas e compartilhadas (KITINZER e BARBOUR, 1998). Interação é a palavrachave de tal técnica; parte-se do pressuposto que as pessoas influenciam umas às outras com seus comentários, e suas opiniões pessoais podem mudar ao longo do processo (KRUEGER, 1994).

Arranjados em torno de uma atividade coletiva como assistir a uma fita de vídeo ou outro recurso áudio-visual, examinar documentos escritos ou apenas discutir alguns tópicos previamente selecionados, os grupos focais são grupos de discussão tradicionalmente utilizados para pesquisas de marketing, bem como na antropologia social, cultural e estudos ligados à saúde. No entanto, esta técnica tem sido adotada e desenvolvida em várias outras ciências sociais (KITINZER e BARBOUR, op.cit.), de 
modo a permitir que se aperfeiçoe o planejamento de novos programas e se avalie aqueles já existentes (KRUEGER, 1994). As vantagens e limitações do uso dos grupos focais são descritas no Quadro 3.

Muitas sugestões de como planejar, conduzir e até mesmo analisar os dados provenientes desses grupos de discussão estão disponíveis na literatura, porém é importante que sejam feitas as adaptações necessárias para a implementação em diferentes áreas, já que o método se apresenta bastante flexível e os procedimentos, tais como seleção dos componentes e número de reuniões, dependem muito dos objetivos da pesquisa (KITINZER e BARBOUR, 1998). Um grupo deve ser pequeno o suficiente para que todos possam manifestar suas idéias, e grande o bastante para que haja uma certa diversidade delas, sendo 12 participantes o número máximo ideal para atender tais premissas (KRUEGER, op.cit.).

Quadro 3: Vantagens e desvantagens da técnica de grupos focais

\begin{tabular}{|l|l|}
\hline \multicolumn{1}{|c|}{ Vantagens } & \multicolumn{1}{|c|}{ Limitações } \\
\hline - captação das dinâmicas de interação das & • menor controle por parte do pesquisador \\
pessoas no grupo; & do que nas entrevistas individuais; \\
- flexibilidade; & - dificuldade de análise dos dados; \\
- grande validade; & - requer habilidades especiais dos \\
- custo relativamente baixo; & moderadores; \\
- resultados potencialmente rápidos; & - heterogeneidade dos grupos e dificuldade \\
- potencial de aumentar a qualidade de um & em reunir as pessoas. \\
estudo qualitativo. & \\
\hline
\end{tabular}

Fonte: KRUEGER (1994)

É importante que o entrevistador esteja bem preparado e para isso é fundamental a elaboração de um roteiro que funcione como um referencial flexível para a entrevista. A forma de registro desses dados é a gravação em fitas cassete para posterior transcrição e análise (GASKELL, 2003).

\subsection{A construção coletiva da trilha interpretativa do meio}

A etapa de construção da trilha constitui-se na intervenção educativa propriamente dita. Seus objetivos foram: 
- Implantar uma trilha interpretativa do meio ambiente, que propiciasse a reflexão e a discussão de conceitos e valores sobre o meio ambiente natural e sócio-cultural relativos à importância da bacia hidrográfica do rio Pardo na biodiversidade local e regional;

- Criar oportunidades de sensibilizar os visitantes e participantes a respeito da complexidade das questões ambientais locais;

- Construir coletivamente alternativas de continuidade do projeto, através do estabelecimento de parcerias com ONGs, escolas, prefeitura municipal, além de proporcionar a formação de monitores ambientais locais.

Durante o processo de construção da trilha interpretativa, foram utilizadas diferentes técnicas de interação de grupo e de coleta de dados. Uma delas é a de grupos focais, utilizada na coleta de dados referentes às expectativas dos participantes e suas sugestões para o roteiro da trilha. Também foram feitas visitas de campo com a finalidade de definir o local de implantação da trilha.

\subsection{Avaliação da atividade de visita à trilha da Tubaca e do processo da pesquisa}

A avaliação tem como uma de suas funções prestar um serviço aos participantes envolvidos no processo educativo, ajudando-os a explicitar as interpretações que cada um elabora sobre a situação a ser analisada (ANADÓN, 2003). A avaliação realizada neste trabalho é o que a autora chama de avaliação interna, que dá aos participantes uma consciência da capacidade de cada um e do grupo, podendo contribuir com a mudança das situações e melhoria das práticas, favorecendo uma reflexão crítica sobre a atuação de cada participante e colaborando com a formação e co-formação dessas pessoas. Nesse tipo de avaliação, os resultados são decorrentes da interação entre o observador e os participantes; estes últimos constituem a fonte principal de dados, com suas interpretações e significações.

Buscou-se flexibilidade na coleta e na análise dos dados, bem como na discussão dos resultados obtidos com os participantes, de forma a valorizar sua subjetividade, na 
tentativa de explicitar os valores, as motivações, as expectativas e as dificuldades, para contribuir com a compreensão da situação e transformá-la.

Neste trabalho houve dois tipos de avaliação: a do uso da trilha e a do processo da pesquisa como um todo. A primeira delas foi feita tanto com os usuários da trilha (estudantes de ensino fundamental), quanto com as pessoas que participaram da construção desta; já a segunda foi conduzida apenas com esses últimos.

\subsubsection{Avaliação conduzida com os estudantes}

A avaliação conduzida com os estudantes, com a finalidade de analisar a atividade de visita à trilha, foi feita através de duas técnicas: a da observação sistemática e a dos grupos focais, ambas com a finalidade de tentar ir além da avaliação da absorção de conteúdos por parte dos estudantes.

Fontes (2003) questiona se a mera difusão de informações a respeito do meio ambiente pode ser considerada uma verdadeira educação ambiental, ou se trata-se de um ensino de ecologia, já que os educandos assumem uma postura passiva diante do conhecimento. Segundo Andrade e Loureiro (2003) a avaliação do indivíduo precisa considerar a capacidade de absorção e articulação dos conhecimentos (cognitivo, racional), a sensibilidade para atuar de acordo com eles (valores, emocional) e a capacidade de aplicá-los nas situações cotidianas.

Os valores não podem ser atribuídos exclusivamente aos conteúdos. É necessário considerá-los num processo contínuo de integração dos conhecimentos na prática diária (DEPRESBÍTERIS, 2003).

No presente trabalho, a pesquisadora adota o papel tanto de observadora como de participante, revelando a sua identidade e os objetivos do estudo ao grupo pesquisado, desde o início do trabalho.

A técnica da observação direta, utilizada nessa fase do processo, consiste em observar uma situação determinada para posterior estudo. As observações que cada um faz são muito influenciadas por sua história pessoal e sua bagagem cultural. Portanto, para que a técnica se torne um instrumento válido e fidedigno de investigação científica, precisa ser controlada e sistemática, o que implica em planejamento e preparação rigorosos, além de registro cuidadoso (LUDKE E ANDRÉ, 1986). Utilizada como uma das formas de avaliação da presente intervenção educativa, possuiu objetivos prédefinidos avaliados através de alguns indicadores (DEPRESBÍTERIS, op.cit.). As 
visitas foram registradas em vídeo e posteriormente analisadas. Comportamentos indicadores de entusiasmo, interesse, integração, cansaço, motivação e iniciativas próprias foram registrados durante as atividades consideradas. Os meios utilizados para o registro de possíveis comentários e atitudes, tanto do monitor ambiental quanto dos alunos, durante a implementação da trilha foram: fitas de vídeo, fotografias e anotações de campo da própria pesquisadora.

Os resultados dessa observação sistemática estão descritos no item referente à implementação da trilha, já que representam a percepção que a pesquisadora teve sobre a atividade. Os resultados dos grupos focais conduzidos com os estudantes serão apresentados no item referente à avaliação da atividade de visita à trilha.

A aplicação de tal técnica objetivou verificar os ganhos que os alunos obtiveram após a visita à trilha, em termos cognitivos (de conteúdos), afetivos, de habilidades e de conscientização. Para tanto, a técnica foi aplicada antes e depois da visita à trilha, com a finalidade de comparar esses aspectos.

Antes da visita à trilha da Tubaca, a avaliação tinha uma finalidade diagnóstica, ou seja, verificar o conhecimento prévio dos estudantes a respeito dos temas a serem discutidos durante a atividade, bem como suas expectativas em relação à mesma. Após a realização da atividade, foi feita uma avaliação caracterizada na literatura como formativa, ou seja, com a finalidade de corrigir rumos, além de rever e aperfeiçoar a estratégia utilizada. Pelos moldes em que foi realizada, essa avaliação também consistiu em mais um momento de aprendizagem (ANDRADE e LOUREIRO, 2003).

\subsubsection{Avaliação conduzida com os participantes locais}

A avaliação conduzida com os participantes do processo teve duas finalidades: avaliar a atividade de visita à trilha pelos estudantes de ensino fundamental e compreender como essas pessoas perceberam o processo de participação em uma pesquisa científica. As técnicas utilizadas para tal avaliação foram: a observação sistemática e os grupos focais.

A primeira foi conduzida durante as reuniões e para isso foram utilizados alguns indicadores com a finalidade de avaliar a participação das pessoas em todas as fases da pesquisa.

Os resultados da avaliação da visita à trilha da Tubaca, conduzida com os estudantes, foram apresentados ao grupo de participantes do processo de construção da 
estratégia educativa. Andrade e Loureiro (2003) consideram a apresentação dos resultados aos participantes como um dos elementos mais importantes no monitoramento e avaliação de projetos, já que possibilita o aprimoramento do processo e a apropriação dele pelos interessados.

A sistemática da informação produzida foi feita através do uso de técnicas simples de comunicação, tais como: slides, vídeos, gráficos, quadros, esboços, cadernetas, entre outros. Essas técnicas de simples manipulação têm a finalidade de facilitar a fase pedagógica de tomada de contato do grupo com os temas levantados e os debates sobre eles (GAJARDO, 1986).

A análise da atividade de visita à trilha e do processo de pesquisa, de acordo com os participantes, foi feita através da técnica de grupos focais. 


\section{FORMAÇÃO E ATUAÇÃO DO GRUPO DE PARTICIPANTES NAS DIVERSAS ETAPAS DO PROJETO}

A principal finalidade das primeiras visitas a São José do Rio Pardo, além de identificar possíveis áreas para a implantação da trilha, era também identificar e contatar pessoas que tivessem interesse e disponibilidade para participar do projeto. A chegada ao local foi acompanhada por uma pesquisadora da comunidade, o que facilitou o processo de entrosamento com os moradores locais. Aos poucos foram sendo identificadas algumas pessoas com o perfil desejado, e elas mesmas traziam para o grupo outros que, em sua opinião, também se interessariam pela proposta. Normalmente aqueles que foram indicados possuíam grande afinidade e interesses comuns aos dos participantes.

Se por um lado essa maneira de organização do grupo facilitou o desenvolvimento do trabalho - já que a pesquisadora não estava inserida na realidade municipal - pode também ter excluído do processo pessoas que, embora tivessem menor proximidade e/ou afinidade com os demais participantes, também poderiam ter interesse na proposta.

Participaram do processo representantes de diversos setores da comunidade como secretarias municipais de Educação, Cultura e Turismo; representante da Secretaria Municipal de Agricultura no comitê da bacia hidrográfica do rio Pardo, representantes de Organizações Não Governamentais (ONGs), empresas e estudantes.

Também participaram o administrador da fazenda na qual seria implantada a trilha e a representante da escola municipal envolvida, ambos convidados pelos próprios participantes para integrarem o grupo.

A proposta de trabalho foi apresentada para a delegada regional de ensino (Apêndice A), que autorizou o desenvolvimento do trabalho nas escolas da rede estadual e permitiu que a decisão final de adesão ao projeto fosse de âmbito dos diretores de cada escola (Anexo A). Dessa forma, a apresentação da proposta e o 
convite para participação das atividades foram feitos à direção e à coordenação de uma escola da rede estadual de ensino, mas diante da demora em definir se participariam ou não do projeto, alguns componentes do grupo decidiram estender o convite aos representantes de uma escola municipal. Estes compareceram prontamente à primeira reunião, disponibilizando-se também a participar das atividades propostas, o que de fato aconteceu.

O processo de construção coletiva da trilha interpretativa apresentou diversos momentos, caracterizados por uma maior ou menor participação dos envolvidos. Percebeu-se que a proposta concebida pela equipe de pesquisa era compatível com os interesses, desejos e necessidades dos participantes, já que todos aqueles com os quais houve um contato inicial mostraram-se bastante interessados no projeto. Era grande o interesse dos participantes em construir trilhas no município como forma de fomentar o turismo de natureza em âmbito regional.

Em todos os encontros informais com os participantes, a proposta de elaborar uma trilha com finalidade de educação ambiental e que englobasse os temas "biodiversidade" e "conservação na bacia do Pardo", era apresentada de forma resumida. Procurou-se sempre deixar claro que a idéia era trabalhar de forma cooperativa e colaborativa na elaboração da trilha, de forma que ela pudesse cumprir com objetivos também propostos por eles.

A primeira etapa de construção coletiva de uma estratégia educativa consistiu em um diagnóstico da situação ambiental municipal feito em conjunto com os participantes. A partir de alguns temas levantados nesse diagnóstico foi elaborada a trilha interpretativa do meio.

O trabalho foi desenvolvido através de reuniões com os participantes locais. As coletas de dados nas etapas de diagnóstico e de elaboração e avaliação da trilha foram feitas por meio da aplicação das técnicas de diagnóstico rural participativo e grupos focais, respectivamente. No total foram realizadas 6 reuniões e 3 visitas à trilha da Tubaca com os estudantes, além de encontros informais na etapa de formação do grupo, e visitas de campo na etapa de escolha do local da trilha.

A primeira reunião objetivou apresentar formalmente o projeto - já que a pesquisadora havia conversado previamente de maneira informal com a maioria dos presentes - esclarecer possíveis dúvidas, obter sugestões, além de verificar as expectativas dos possíveis participantes em relação ao projeto, bem como seus 
interesses, e disponibilidade para atuarem como parceiros em todo o processo de elaboração da trilha.

Quadro 4: Categoria de envolvimento no projeto e ocupações dos participantes de São José do Rio Pardo.

\begin{tabular}{|c|c|}
\hline \multirow{9}{*}{ Participantes efetivos } & $\begin{array}{l}\text { Comerciante e guia de agência de esportes de } \\
\text { aventura }\end{array}$ \\
\hline & Diretor Municipal de Infra-estrutura \\
\hline & Secretário de Turismo \\
\hline & Estudante, estagiária da Secretaria de Turismo \\
\hline & Estudante \\
\hline & Diretora Municipal de Fomento ao Turismo \\
\hline & Empresário de agência de esportes de aventura \\
\hline & Biólogo e agricultor \\
\hline & $\begin{array}{l}\text { Comerciante, bacharel em direito e estudante de } \\
\text { história }\end{array}$ \\
\hline \multirow{7}{*}{ Participantes eventuais } & $\begin{array}{l}\text { Coordenadora da Escola Municipal Stella Maris } \\
\text { Barbosa Catalano }\end{array}$ \\
\hline & $\begin{array}{l}\text { Representante da ONG Sorria e Escola Estadual } \\
\text { Prof. Tarquínio Olintho }\end{array}$ \\
\hline & Produtor rural - administrador da fazenda Tubaca. \\
\hline & $\begin{array}{l}\text { Diretora da Escola Municipal Stella Maris Barbosa } \\
\text { Catalano }\end{array}$ \\
\hline & $\begin{array}{l}\text { Agrônomo - Secretaria Municipal de Agricultura e } \\
\text { Meio Ambiente }\end{array}$ \\
\hline & $\begin{array}{l}\text { Coordenadora da Escola Municipal Stella Maris } \\
\text { Barbosa Catalano }\end{array}$ \\
\hline & Ex-presidente da ONG Nativerde \\
\hline \multirow{2}{*}{$\begin{array}{c}\text { Participantes do curso de formação } \\
\text { de monitores }\end{array}$} & Empresário rural/ veterinário \\
\hline & Estudante \\
\hline \multirow{8}{*}{$\begin{array}{l}\text { Participantes da avaliação / propostas } \\
\text { de continuidade do projeto }\end{array}$} & Presidente da ONG Nativerde \\
\hline & Secretária de Turismo \\
\hline & Representante do Colégio Lúmen \\
\hline & $\begin{array}{l}\text { Agrônomo - Secretaria Municipal de Agricultura e } \\
\text { Meio Ambiente }\end{array}$ \\
\hline & \begin{tabular}{|l}
$\begin{array}{l}\text { Representante da Escola Estadual Euclides da } \\
\text { Cunha }\end{array}$ \\
\end{tabular} \\
\hline & \begin{tabular}{|l}
$\begin{array}{l}\text { Representante da Escola Estadual Dr. Cândido } \\
\text { Rodrigues }\end{array}$ \\
\end{tabular} \\
\hline & $\begin{array}{l}\text { Coordenadora da Escola Municipal Stella Maris } \\
\text { Barbosa Catalano }\end{array}$ \\
\hline & $\begin{array}{l}\text { Representante da Escola Estadual Laudelena O. } \\
\text { Pourrat }\end{array}$ \\
\hline
\end{tabular}

O grupo nomeou o projeto de "Arrasta-pé na trilha". Notas ou reportagens a respeito do desenvolvimento deste eram freqüentemente publicadas por alguns dos participantes nos jornais locais, como forma de divulgação das ações na cidade (Anexo B).

Por fim, um total de 26 pessoas envolveram-se de alguma forma com o projeto, das quais 9 podem ser consideradas participantes efetivos do processo como um todo, 7 
foram participantes eventuais (de apenas algumas etapas), 2 pessoas participaram apenas do curso de formação de monitores oferecido, e 8 pessoas participaram apenas da avaliação e das propostas para a continuidade do projeto (Quadro 4). 


\section{DIAGNÓSTICO DAS POTENCIALIDADES E DOS PROBLEMAS AMBIENTAIS LOCAIS}

O diagnóstico participativo das potencialidades e dos problemas ambientais de São José do Rio Pardo, embora tendo sido programado para ser realizado em apenas uma reunião (29/06/04), estendeu-se por mais um encontro (13/07/04), ambos realizados na Câmara Municipal de São José do Rio Pardo.

A primeira potencialidade citada pelos participantes foi o rio Pardo, considerado por todos como um elemento natural muito importante para o município.

"O rio é fundamental na história da cidade".

Diretora Municipal de fomento ao turismo.

" [o rio Pardo] tá no nome da cidade".

Empresário de uma agência de esportes de aventura.

No entanto, após algum debate, o potencial considerado mais relevante foi definido como sendo a história sócio-ambiental local, pois esta seria mais abrangente que o item "rio Pardo", não deixando, no entanto, de envolvê-lo. Ao contrário, ressaltou-se que o rio Pardo está estreitamente ligado à história sócio-ambiental municipal, sendo um elemento natural preponderante desta.

“...em função do rio...os fazendeiros vieram pela beleza e a fertilidade do rio...”. Diretora Municipal de fomento ao turismo..

"Essa biodiversidade que tem aqui é também por causa do rio que tem aqui". Representante da ONG Sorria.

Outros aspectos da história sócio-ambiental local ligados ao rio Pardo citados foram: a Revolução de 32, que teve alguns de seus episódios ocorridos às margens do rio, e o uso do solo, que reflete o destaque do município na agropecuária regional. 
Também foram citadas como potenciais ambientais a biodiversidade local, como resultado da preservação das áreas naturais na região.

Houve um certo mal-entendido nessa primeira reunião: os participantes pensaram que estávamos levantando os potenciais e problemas da Fazenda Tubaca e mais especificamente da área onde seria implantada a trilha; então, muitos dos itens levantados referiam-se especificamente a essa área e não ao município como um todo.

$\mathrm{Na}$ segunda reunião esse aspecto foi esclarecido e foi pedido para que os participantes refizessem a lista dos problemas e potenciais, desta vez, pensando no município e não apenas na fazenda ou na trilha. Dessa forma poderia-se ampliar o foco da discussão e inserir no roteiro da trilha temas ambientais, tanto positivos quanto negativos, do município de São José do Rio Pardo como um todo.

Mesmo após esse esclarecimento, as potencialidades já citadas e sua ordem de importância foram mantidas, justificadas ainda pela forte presença dos aspectos histórico-culturais da cidade, e que, de qualquer forma, apresentam o rio Pardo como o elemento principal.

Uma outra dúvida que surgiu nessa etapa foi em relação ao enfoque que deveria ser dado a essas potencialidades, ou seja, se seriam potenciais relacionados ao turismo, à economia, à sociedade, entre outros. Esse questionamento surgiu a partir da dúvida em acrescentar os itens agricultura e pecuária como potenciais locais. Os participantes alegaram que se esses dois itens fossem adicionados, deveria-se acrescentar também como potenciais o comércio, a educação e a saúde - setores nos quais o município possui um destaque regional.

$\mathrm{Na}$ verdade essa dúvida em definir quais desses aspectos poderiam ser considerados como potencialidades ambientais, demonstra pouca clareza do conceito de meio ambiente por parte dos envolvidos.

\footnotetext{
“Eu acho o seguinte: aí se você pode... por a agricultura, o comércio, saúde, educação, é tudo potencial... na região é uma potência, é tudo centralizado aqui..." Diretor Municipal de infra-estrutura.
}

Voltando a pensar nos potenciais com finalidade educativa e turística, já que esta última era a principal expectativa dos participantes em relação à trilha, estes optaram por acrescentar como um potencial todos os produtos (com valor agregado) originários da área rural, tais como: a aguardente, a cebola, os produtos defumados derivados de carne bovina, entre outros. 
Por fim, o grupo chegou à conclusão de que todas as potencialidades citadas estão interligadas. Vários aspectos sócio-culturais do município (a ocupação local, o euclidianismo, os produtos cultivados, a pesca, entre outros) têm algum tipo de relação com o rio Pardo. A biodiversidade presente na região também tem, na opinião do grupo, como fator preponderante, relação com a presença do rio.

\footnotetext{
“... a gente tem trabalhado, os pontos principais no turismo seria o histórico-cultural que estaria contemplado aqui pela historia sócio-ambiental, a ponte, o Euclides... tal, daí o rio Pardo que tá ligado à natureza e a questão da topografia, da geografia, tá entrando nisso aqui, a variedade de espécies, a biodiversidade... têm a ver com essa localização, né? E questão da preservação como questão de qualidade de vida ligando tudo isso...”.

Diretora Municipal de fomento ao turismo.
}

O quadro 5 resume as potencialidades municipais levantadas pelo grupo, em ordem de importância. Percebe-se que dentre os itens citados estão elementos naturais do meio (rio Pardo, áreas naturais conservadas), aspectos históricos, sócio-culturais e econômicos.

Quadro 5: Potencialidades ambientais municipais em ordem decrescente de importância.

\begin{tabular}{|l|}
\hline \multicolumn{1}{|c|}{ Potencialidades } \\
\hline 1 - História Sócio-ambiental \\
\hline 2 - Rio Pardo \\
\hline 3 - Biodiversidade \\
\hline 4 - Conservação das áreas naturais \\
\hline 5 - Produtos originários da área rural \\
\hline
\end{tabular}

Em relação aos problemas ambientais locais, o fogo foi considerado, em princípio, como o mais grave, por dois participantes. No entanto, houve discordância e debate. Outras duas pessoas consideraram como principais problemas, a poluição dos rios e córregos através do esgoto.

"O fogo é o pior".

Secretário Municipal de Turismo.

"O problema do fogo é o seguinte: ele pode ser mais grave, mas ... se for analisar, a participação do indivíduo na poluição do meio ambiente, talvez ... lixo, poluição... [sejam piores]”.

Representante da Secretaria Municipal de Agricultura e Meio Ambiente. 
"O que eu acho importante seria a poluição por esgoto, principalmente. O lixo vai pro lixão, o esgoto vai, praticamente pro...[rio]”.

Ex-presidente da ONG Nativerde.

"Pior é o esgoto. Esgoto é um problema sério e muito caro de resolver!".

Diretor Municipal de infra-estrutura.

O segundo problema citado foi o do lixo, porém, assim como aconteceu com as potencialidades, esta questão esteve voltada para o local da trilha. Foi discutido que as pessoas jogam muito lixo na mata, lembrando, inclusive, que o próprio grupo encontrou bastante lixo nas visitas de reconhecimento de locais para implantação da trilha. Apenas uma participante referiu-se ao problema do lixo de forma um pouco mais ampla, ou seja, refletindo a respeito de outros problemas que poderiam derivar dessa questão.

“... uma coisa que eu acho que é importante: o fogo queima e destrói. O lixo você vai lá e recolhe ...".

Diretora Municipal de fomento ao turismo.

"O lixo, principalmente para os córregos, [causa] poluição ambiental. Essa poluição leva a quê? A um prejuízo, a uma ameaça à saúde da população, né? Porque a água de pior qualidade...”.

Ex-presidente da ONG Nativerde.

Várias outras questões, tais como a retirada de materiais da natureza (principalmente orquídeas e terra para jardinagem) e a questão dos agrotóxicos, ainda foram abordadas do ponto de vista da mata e não do município como um todo.

"A questão da retirada de muda na mata, eu acho que isso é uma coisa que acontece muito em trilha é a retirada de coisas da mata (...) a pessoa vai lá 'ai que bonitinho', $e$ cada um quer levar...”.

Diretora Municipal de fomento ao turismo.

"Eu não vejo muito problema na visita, você pegar alguma semente, uma semente do chão. $O$ perigo são os caçadores de orquídeas, né? Agora o pessoal que importa produção pra levar terra do mato para os vasos... quer dizer, ainda se tirar um pouquinho tudo bem, mas se tirar um montão...”.

Administrador da Fazenda Tubaca.

“Ah, mas também se cada um for retirar um pouquinho...”.

Diretora Municipal de fomento ao turismo.

Depois de muito debate e após esclarecermos as dúvidas a respeito do enfoque que seria dado aos problemas, enfatizando que eles deveriam abranger todo o município e não apenas a mata ou a trilha, o grupo chegou a um acordo de que, em termos gerais do município, o pior problema é a poluição dos rios e córregos por esgoto. 
“... da mata ou é mais geral? Ah, geral então é... Se for geral é saneamento básico... Nós não estamos falando do mato mais, né? Saneamento básico, sim. Eu acho até que mais que o fogo. Eu tava pensando na mata. Eu poria o saneamento básico".

Secretário Municipal de Turismo.

"É, se for geral é saneamento, se for na mata é fogo".

Diretor Municipal de infra-estrutura.

O fogo acabou sendo considerado o segundo mais relevante. O lixo foi colocado logo abaixo do fogo pelo fato de poder ser "tratado". A erosão também foi considerada um problema muito importante. O desmatamento ficou em quarto lugar porque, segundo eles, atualmente são poucas as áreas de mata existentes, e estas estão protegidas por uma legislação severa.

O Quadro 6 resume os principais problemas e a suas magnitudes no município de São José do Rio Pardo, de acordo com os participantes. Todos os problemas citados causam impacto direto em elementos naturais do meio.

Quadro 6: Principais problemas ambientais em ordem decrescente de importância.

\begin{tabular}{|l|}
\hline \multicolumn{1}{|c|}{ Problemas } \\
\hline 1- Poluição dos córregos por esgoto \\
\hline 2- Fogo \\
\hline 3- Lixo / Erosão \\
\hline 4- Desmatamento (mata ciliar) e retirada de materiais da natureza \\
\hline 5 - Uso de agrotóxicos \\
\hline 6- Caça e Pesca \\
\hline
\end{tabular}

Em conseqüência do fato das discussões a respeito da trilha, das sugestões e dúvidas terem se estendido muito, não houve tempo suficiente para finalizar as técnicas de diagrama de Venn e diagrama de Fluxos. Assim, no segundo encontro, a proposta era retomar os problemas e potencialidades levantadas anteriormente, estabelecer prováveis relações de causa e conseqüência entre elas, bem como discutir a quem competiria solucionar esses problemas e propor possíveis formas de minimizá-los. Estiveram presentes, nesse encontro, sete pessoas, que sugeriram que separássemos os problemas em duas categorias: os mais relevantes na área rural e os mais relevantes na área urbana do município. Eles justificaram essa decisão pelo fato de que muitos dos problemas citados na reunião anterior possuem diferentes dimensões quando analisados nesses dois contextos. 
"A discussão é do município inteiro? Então é complicado, né? Porque a região urbana é diferente da rural. Teria que discutir as duas separadas... Na urbana as prioridades são essas, na rural as prioridades são essas... Não bate! Que nem fogo, fogo não tem nada a ver com urbano, mas na rural ... tratamento de esgoto é totalmente urbano, não tem nada a ver com o rural... são focos diferentes... uma coisa que é prioritária no urbano não é no rural....".

Diretor Municipal de infra-estrutura.

Dessa forma, o diagrama construído pelos participantes para os problemas ambientais da área rural do município pode ser visto na Figura 4.

$\mathrm{O}$ fogo foi considerado o problema mais grave na área rural, seguido pelo desmatamento. A principal justificativa dada é que, em tese, depois de iniciada, a queimada dificilmente pode ser controlada; ao contrário do desmatamento, que pode ser interrompido.

“Eu acho que é o fogo porque o fogo você não controla, né?”.

Diretor Municipal de infra-estrutura.

"O fogo não controla e depois que queimou, acabou... Não tem mais árvore, não tem mais nada”.

Empresário de uma agência de esportes de aventura.

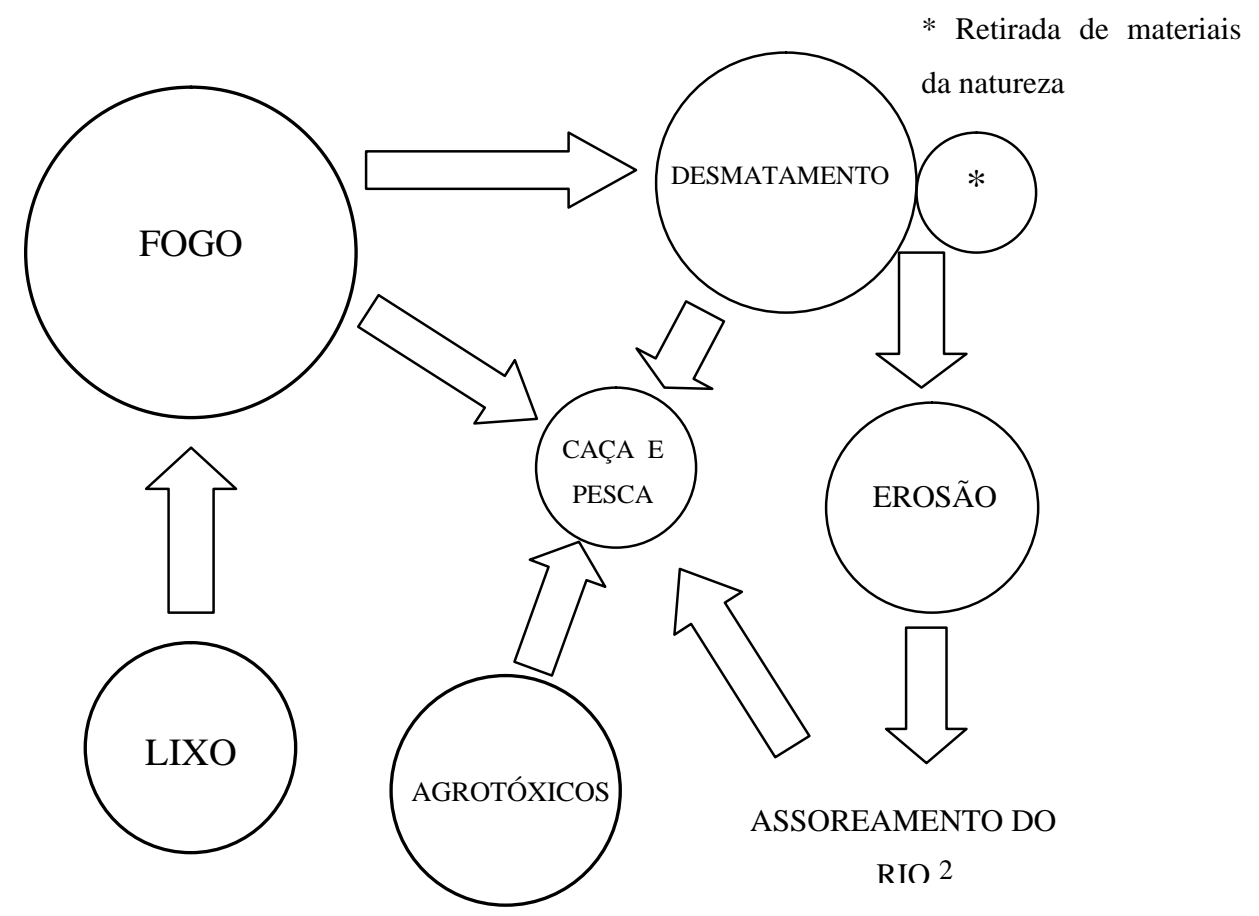

FIGURA 4 - Diagrama representativo dos principais problemas ambientais encontrados na área rural de São José do Rio Pardo e das relações entre eles.

\footnotetext{
${ }^{2}$ Embora identificado como conseqüência da erosão, este item não foi representado em um círculo por não ter sido considerado um problema relevante no contexto local.
} 
De acordo com o que tinha sido dito anteriormente, percebeu-se que os participantes estavam se referindo às queimadas acidentais. Porém, sabe-se que muitas vezes essa prática é utilizada para aumentar as áreas cultiváveis, seja destruindo a vegetação natural, ou mesmo eliminando a cultura anterior. Em ambos os casos, as queimadas trazem prejuízos ao solo.

Nos anos de 2001 e 2002, o número de autuações por queimadas foi muito grande, mas, segundo os participantes, esse número tem diminuído nos últimos dois anos (informação verbal) $)^{3}$. Acredita-se que essas queimadas aconteçam acidentalmente ou por descuido, já que atualmente elas não têm sido utilizadas (ou são utilizadas raramente) como prática de manejo agrícola no município, embora esta seja uma prática comum para limpeza de terrenos baldios na área urbana. Esse último comentário invalida a fala anterior de um dos participantes, de que o fogo seja um problema existente somente na área urbana municipal.

Em relação à prática do desmatamento para ampliação da área cultivável, tem ocorrido o processo inverso no município: em locais onde a agricultura era praticada de forma manual, em razão das dificuldades financeiras enfrentadas pelos pequenos produtores, muitos deles têm abandonado essas áreas para trabalhar onde o cultivo seja mecanizado, permitindo que essas áreas comecem a se regenerar naturalmente (informação verbal) ${ }^{4}$.

No que se refere às queimadas e ao desmatamento, foram citadas como forma de minimização, a conscientização tanto do produtor, quando de outras pessoas, bem como a fiscalização e a punição por parte da polícia ambiental.

\footnotetext{
"O desmatamento também é [conscientização]... Porque tem aquele fogo que a pessoa jogou um cigarro e aquele fogo que é proposital para aumentar o desmatamento, para aumentar a área cultivável... Um você tem que conscientizar, o outro já é problema de política...”.

Diretor Municipal de infra-estrutura.

"É o caso da cana-de-açúcar...”.

Estudante.

"Quem pôs fogo? Ninguém sabe, até provar que foi você. Agora o desmatamento você pega a pessoa lá com a mão na massa, né?.... apesar de que agora se você puser fogo em algum lugar, você tem que fazer o replantio proporcional, se for você ou não, o fazendeiro é culpado hoje"

Diretor Municipal de infra-estrutura.
}

\footnotetext{
${ }^{3}$ Informação fornecida pelo Sargento da Polícia Ambiental de São José do Rio Pardo, em março de 2005.

4 Informação fornecida pelo engenheiro agrônomo da Secretaria Municipal de Agricultura e Meio Ambiente de São José do Rio Pardo, em março de 2005.
} 
A Secretaria Municipal de Agricultura e Meio Ambiente, em convênio com outras instituições tais como a UNESP de Jaboticabal, o sindicato rural, entre outras, está implantando em São José do Rio Pardo, uma Fundação Municipal de Pesquisa Agrícola, com o intuito de pesquisar e divulgar aos produtores rurais locais, técnicas mais sustentáveis de manejo de solo, de irrigação, de plantio (tais como o plantio fora de época e o plantio na palha), já que a maioria dos pequenos produtores locais não têm acesso a essas tecnologias (informação verbal/ Secretaria Municipal de Agricultura e Meio Ambiente).

Houve uma pequena discordância a respeito de qual problema seria considerado o terceiro mais relevante na área rural: se o uso de agrotóxicos, se o desmatamento ou o lixo e a erosão. O grupo acabou optando pelo agrotóxico.

\footnotetext{
“O lixo e o agrotóxico acho que pode ficar mais ou menos junto, viu...”. Empresário de uma agência de esportes de aventura.

“Não acho, acho o agrotóxico bem pior que o lixo". Diretor Municipal de infra-estrutura.

“... a poluição dos córregos por agrotóxicos na área rural é um problema grave”. Diretora Municipal de fomento ao turismo.

"Porque córrego poluído é na zona urbana, na zona rural não tem córrego poluído, tem uso de agrotóxico, que eu não sei quanto que afeta... se quando chove leva isso aí pros córregos, se existe matança de peixe..."

Diretor Municipal de infra-estrutura.

"Eu já ouvi que [matança de peixe acontece]... Mas porque o cara... pulverizou [a plantação de laranja], choveu durante a noite, desceu, matou todos os peixes...”. Empresário de uma agência de esportes de aventura.
}

De acordo a Secretaria Municipal de Agricultura e Meio Ambiente, existe sim uso intensivo de agrotóxicos nas culturas temporárias, tais como cebola e demais hortaliças. Embora não haja dados precisos de quantidade de agrotóxicos e outros suplementos agrícolas utilizados, estima-se que esse número seja, em média, de 10 a $15 \mathrm{~kg}$ por hectare (cerca de 2200 hectares do município são destinados ao plantio de cebola). A média de produção de cebola, principal cultura do município, é de 37 toneladas por hectare, e a média nacional desse produto é de 24 toneladas por hectare. Em 2004, chegou-se a produzir, em São José do Rio Pardo, 94 toneladas de cebola por hectare, utilizando uma nova técnica de plantio: o plantio na palha ${ }^{5}$.

\footnotetext{
${ }^{5}$ Segundo informações verbais (Secretaria Municipal de Agricultura e Meio Ambiente), essa técnica consiste no plantio em uma camada vegetal morta, o que dispensaria o revolvimento do solo e o uso de implementos agrícolas.
} 
A Fundação de Pesquisa Agrícola Municipal também vai passar a receber as embalagens vazias de agrotóxicos que até então os produtores eram obrigados a entregar num posto de recebimento em Casa Branca. Isso possibilitará estimar a quantidade de agrotóxico utilizada nas culturas locais.

Também não existem dados sobre a contaminação de solos, de produtos comestíveis, bem como de corpos d'água por agrotóxicos. Eventualmente ocorre mortandade de peixes em açudes em razão do carreamento de produtos tóxicos das culturas às águas, por meio da chuva (informação verbal/ Secretaria Municipal de Agricultura e Meio Ambiente).

Além da questão dos agrotóxicos, a caça e a pesca ilegais também foram identificadas como problemas graves no município.

\footnotetext{
"A caça aqui também é grande, especialmente em termos de ave. Aqui é rota de tráfico de aves".

Representante da ONG Sorria.

“E a caça com redes, né? É uma coisa bem... que tem bastante, bastante, bastante...” Empresário de uma agência de esportes de aventura.

“...a gente tá na rede lá fora [ilha das cabritas] e a gente começou 'o que é isso, que tá vindo esse monte de canoa?' ... aí a gente fala 'tá pescando' e quer dizer, não é a pesca, era a caça ... eles estavam procurando capivara, paca....”.

Empresário de uma agência de esportes de aventura.
}

De fato, embora haja indícios de tráfico de animais silvestres em cidades vizinhas a São José do Rio Pardo, tais como Caconde, Divinolândia e Tapiratiba, a Policia Ambiental Municipal acredita que essa prática não ocorra em São José do Rio Pardo. Ocorre, sim, um grande número de apreensões de animais silvestres em cativeiros domésticos, através de denúncias. Também há casos de comércio de animais silvestres na cidade. Depois de apreendidos, esses animais são soltos em áreas autorizadas pelo IBAMA (Instituto Brasileiro do Meio Ambiente e dos Recursos Naturais Renováveis). A pesca também é uma prática comum, mas, na maioria das vezes, os pescadores possuem autorização deste órgão para realização dessa atividade, e respeitam as normas de uso de equipamentos permitidos e de tamanho mínimo para captura de peixes (informação verbal/ Polícia Ambiental Municipal).

Apesar de inicialmente o grupo ter pensado que esse problema não tinha nenhuma ligação com os demais, a caça e a pesca foram relacionadas ao fogo, ao desmatamento, ao agrotóxico e, indiretamente, também à erosão. 
"É, caça e pesca eu acho que ele é ...independente de qualquer outro... É um problema que acho não tem uma ligação tão direta com o lixo ou o fogo. Independente se tiver lixo e fogo o pessoal tá caçando e tá pescando...".

Empresário de uma agência de esportes de aventura.

"Não, o fogo tem, né? Quando pega fogo nessas matas aí, o que mata de bicho... Muitos morrem, né?".

Diretor Municipal de infra-estrutura.

"Eles vão ter que procurar outro habitat... mas aí prejudica a caça. O fogo prejudica a caça”.

Coordenadora pedagógica.

Além da importância da fauna para o equilíbrio do ecossistema, também foi ressaltada a sua beleza.

"Porque a manutenção de uma mata ela precisa especialmente dos animais que vivem nela, se você tem a caça, você tem o desequilíbrio, você provoca o desequilíbrio da mata, entendeu, é o ecossistema".

Representante da ONG Sorria.

"É, a fauna é importante, eu acho... lógico, é importante para a mata, com a fauna é mais bonito ainda do que só mata só de árvores, e um rio só água e não ter peixes, né? É o que acontece aqui no nosso [rio]...”.

Diretor Municipal de infra-estrutura.

Como forma de minimizar a caça e a pesca, foram citadas a fiscalização e a punição por parte dos órgãos competentes, no caso, a Polícia Ambiental, bem como a conscientização da população em geral.

A Polícia Ambiental de São José do Rio Pardo costuma desenvolver, nas escolas do município, palestras educativas de prevenção ao tráfico de animais silvestres, juntamente com outras instituições parceiras, tais como a ONG Sorria.

No que se refere à retirada de plantas nativas, especialmente orquídeas, também considerada um problema relevante na zona rural, foram citadas como forma de minimização a punição, a fiscalização e a conscientização da comunidade.

A figura 5 representa os principais problemas ambientais encontrados na área urbana de São José do Rio Pardo e as relações entre eles, na visão dos participantes locais.

$\mathrm{Na}$ área urbana, a questão da poluição dos córregos por esgoto foi considerada a questão mais grave. Vale destacar que o município ainda não possui um sistema de tratamento de esgoto; assim, todo o esgoto gerado em São José do Rio Pardo é despejado no rio Pardo. 
“Esgoto é assim, disparado, o primeiro...esse não tem nem... 'hors concours'., Diretor Municipal de infra-estrutura.

"Tanto é que o rio fica poluído e a gente percebe navegando no rio, da ponte ali do Euclides pra baixo... Até a usina. Só a cidade, a parte da zona rural é totalmente limpa”. Empresário de uma agência de esportes de aventura.

“Tem, tem, tem... a gente percebe, vamos supor, sem analisar nada, navegando mesmo no rio, a gente sente o cheiro ... da água. E depois que passa da ponte do Euclides ali, aí a coisa fica mais feiosa. Antes, até chegar na ilha de S.Pedro ali é uma maravilha”. Empresário de uma agência de esportes de aventura.

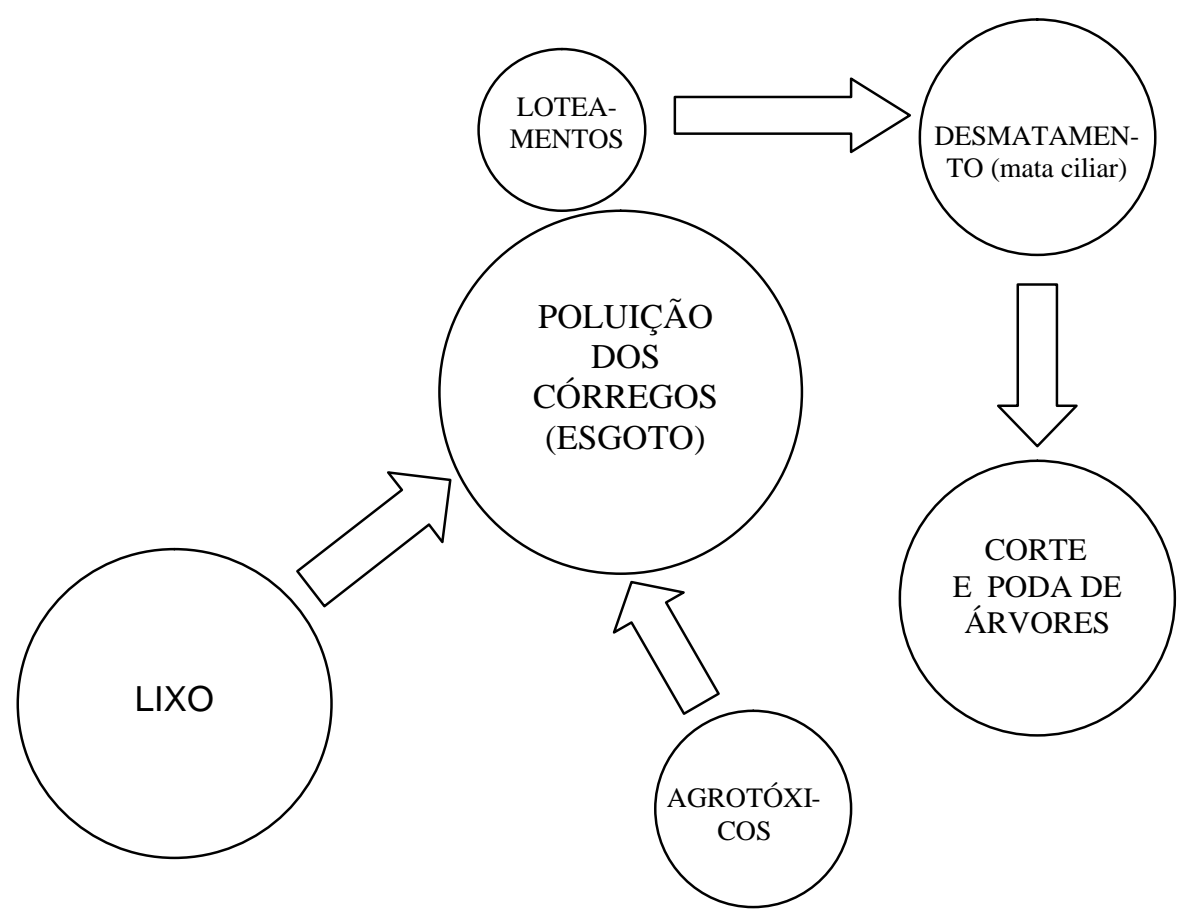

FIGURA 5 - Diagrama representativo dos principais problemas ambientais encontrados na área urbana de São José do Rio Pardo e das relações entre eles.

Segundo os participantes, a única maneira de minimizar este tipo de poluição seria a adoção de um sistema de tratamento do esgoto municipal, que exige uma infraestrutura cara, e demanda tempo para ser construída e entrar em funcionamento.

A questão do lixo também foi considerada grave no município.

"Tem que ver também, acho que além da coleta, a gente sempre pensa na parte dela, esse lixo vai pra algum lugar, né ?”.

Diretor Municipal de infra-estrutura.

"Da rua vai para um aterro e agora tem a coleta seletiva que é o projeto Recicla São José”.

Representante da ONG Sorria.

"Mas tá pequeno ainda...".

Empresário de uma agência de esportes de aventura. 
"Será que o nosso aterro preenche os quesitos ?".

Diretor Municipal de infra-estrutura.

“Aí eu não sei...”.

Diretora Municipal de fomento ao turismo.

“Tecnicamente falando não, mas é o que está autorizado para ser usado... porque não tem outra solução... porque ele está em topo de morro, que é uma coisa que não pode... nos últimos vinte anos nunca teve autorização...”.

Representante da ONG Sorria.

O local utilizado para a disposição final de resíduos sólidos do município de São José do Rio Pardo consiste em um aterro em valas que, segundo a Secretaria Municipal de Agricultura e Meio Ambiente, possui uma licença prévia da CETESB - Companhia de Tecnologia de Saneamento Ambiental. (informação obtida em caráter informal, através da Secretaria Municipal de Agricultura e Meio Ambiente).

O crescimento da cidade também foi citado como uma das causas do aumento da produção de lixo no município.

A reciclagem foi citada como uma maneira de minimizar a quantidade de resíduos que vai para o aterro municipal. Comentou-se a respeito de um projeto da Promotoria Social, o "Projeto Recicla São José", que tem envolvido catadores de lixo, associados em forma de cooperativa, na coleta e separação dos materiais recicláveis para venda. Até o mês de maio de 2005, poucos bairros tinham sido abrangidos pelo projeto e, além disso, muitos catadores ainda continuavam na coleta informal. Os participantes disseram também que a questão da coleta e disposição final dos resíduos é de competência do poder público, não devendo visar a lucro, já que envolve processos com pouco retorno financeiro.

\footnotetext{
"Ah pouquíssimo, aqui de todo o lixo que é produzido por dia, 5 mil $\mathrm{kg}$ pode ser reciclado... São 27 mil kg por dia de lixo ... é porque o pessoal ainda não tem o hábito de separar... Acredito que $40 \%$ no máximo está sendo reciclado... porque eles estão pegando 10 bairros, mais ou menos... é que o problema deles lá ainda é a estrutura, entendeu, não é a satisfação populacional, o problema deles é a estrutura, é a organização”.

Representante da ONG Sorria.

"Tem gente que tá dentro do projeto e tem gente que tá fora do projeto... Tem muitas famílias que vivem disso mas estão fora do projeto...".

Diretora Municipal de fomento ao turismo.

“...quem ficou fora do projeto, muitos deles optaram por estar fora, porque ganham mais trabalhando por fora ...”.

Diretora Municipal de fomento ao turismo.
} 
Também foram citadas a redução e a reutilização dos resíduos como forma de minimização do lixo produzido, bem como a conscientização da comunidade com relação a essa questão, por meio de projetos educativos. Acredita-se que um projeto de gerenciamento dos resíduos não possa ser desvinculado da sua divulgação para a comunidade, bem como da sua sensibilização, para que haja mobilização desta.

\footnotetext{
"Aí é uma questão que talvez fosse interessante da gente trabalhar bastante que é a questão da educação...de educar para não ter o lixo, pra não se jogar o lixo...”. Diretora Municipal de fomento ao turismo.
}

Com relação ao desmatamento na área urbana, os participantes comentaram que este foi muito grande durante a ocupação do local pelos primeiros habitantes de São José do Rio Pardo, e que o maior prejuízo foi o da mata ciliar, já que a área urbana do município se desenvolveu às margens do rio. Hoje, existem, no município, apenas alguns remanescentes da vegetação nativa.

\footnotetext{
"Ah, no urbano não tem mais desmatamento de árvore nativa, isso aqui não existe... existe é desmatamento de árvores de rua, de praça, que é árvore que você planta... Mas nativa não tem mais nada aqui”.

Diretor Municipal de infra-estrutura.

"Seria assim, que nem, você foi na Mata do Carneirinho. Você vê lá, é um bairro nobre... aquela mata antes era enorme então, assim, foram acabando com a mata pra fazer loteamento... O desmatamento é o avanço da cidade, da zona urbana na zona rural também né?".

Estudante.
}

Atualmente, na área urbana, o que se verifica é uma arborização inadequada, que gera um número grande de pedidos de corte e poda de árvores em espaços públicos municipais, algo que é uma situação bastante comum nas cidades brasileiras.

“... é um plantio inadequado que aí ele acaba gerando o corte também de árvore, mas não um desmatamento, parece que é um desmatamento mas é outra coisa... Então no momento, a gente precisa fazer uma adequação ... Existe um sistema de arborização em São José do Rio Pardo equivocado. Então, tem árvores grandes num lugar inadequado”. Diretora Municipal de fomento ao turismo.

"Por exemplo, ontem mesmo eles acabaram de cortar 3 palmeiras imperiais, 4 não sei bem, em frente a museu Rio-pardense. Eles foram plantados, assim, o próximo prefeito vai pôr os fios por baixo da terra e não mais aéreo, aonde foram plantados... O próximo prefeito não pôs os fios de forma subterrânea. Então os fios continuaram aéreos e as palmeiras imperiais crescendo. Ontem elas foram liquidadas, porque elas iam sendo cortadas, cortadas, parecendo um alfinete, ficava só o tronco. Então é uma arborização equivocada e assim a cidade tem muitos lugares... Com relação à questão da segurança também muitas praças tiveram retirada de árvores e limpezas maiores em função da 
argumentação da segurança... é uma arborização equivocada mesmo, acho que teria que ter um planejamento".

Diretora Municipal de fomento ao turismo.

Essa questão do corte e da poda de árvores foi relacionada às alterações climáticas, à poluição do ar e à poluição sonora.

\footnotetext{
“É corte e poda... se tem ligação com alguma outra coisa? Tem, com o clima, lógico! Eu acho que o corte e a poda errado vai influenciar no clima, poluição sonora, poluição de pó, de ar, a parte térmica também porque a cidade fica uma cidade mais quente, sem árvore...".

Diretor Municipal de infra-estrutura.
}

Como forma de minimizar a questão do corte e da poda de árvores na área urbana, os participantes propuseram um projeto de arborização urbana, no qual fosse feito um planejamento dos locais de plantio das espécies a serem utilizadas para tal finalidade, de forma a diminuir os danos em calçadas e na rede elétrica.

\footnotetext{
“...que nesse projeto, cada rua tenha a árvore certa para plantar... se você, lá na frente da tua casa, quiser plantar uma árvore. Você tem que vir no setor de agricultura e perguntar 'que árvore que é que ta indicada na frente da minha casa? Ah, a sua casa é na Rua tal, na quadra tal, você tem que plantar lá um'... sei lá... chapéu de praia...”.

Diretor Municipal de infra-estrutura.
}

No ano de 1968, a cidade foi toda arborizada com sibipiruna (Caesalpinia peltophoroides) de forma que nos anos 80 e 90 havia um maior número de árvores na cidade. Atualmente são muitos os pedidos de corte e poda de árvores recebidos pela Secretaria Municipal de Agricultura e Meio Ambiente. As principais justificativas dos moradores são, de fato, a "sujeira" provocada pela queda de folhas e o rompimento das calçadas. As ruas centrais são bastante estreitas e as árvores também não são bemvindas na área comercial, pois impedem a visão das placas de publicidade e dos outdoors. Esses pedidos de corte de árvores são avaliados, e nos casos em que o corte é permitido, de acordo com uma lei municipal, a árvore é substituída por uma espécie mais adequada ao local (informação verbal/ Secretaria Municipal de Agricultura e Meio Ambiente).

Referente à mata ciliar, o maior problema enfrentado pela Secretaria Municipal de Agricultura e Meio Ambiente é o fato da maioria das propriedades localizadas às margens do rio Pardo ser privada. As poucas áreas verdes públicas constituem-se, em sua maioria, em áreas de lazer, como a Ilha de São Pedro e a Erma. 
A Secretaria Municipal de Agricultura e Meio Ambiente também tem enfrentado dificuldades em algumas das suas iniciativas de arborização urbana, tais como depredação e queimadas em um determinado loteamento, no qual foram plantadas 6 mil mudas de espécies nativas, em março de 2004. Outro caso aconteceu em uma área de recuperação da Mata do Carneirinho, onde também foram plantadas algumas mudas, o que gerou reclamações por parte de alguns moradores do local, preocupados com questões de segurança.

A questão dos agrotóxicos foi considerada a quinta mais relevante na área urbana. Alegou-se que esses produtos são utilizados, embora em pequena escala, para eliminar plantas rasteiras e ou arbustivas nas calçadas, quintais e terrenos baldios da cidade. Comentou-se também que o agrotóxico pode poluir o ar durante sua aplicação.

\footnotetext{
"Pelo que eu entendi o agrotóxico fica no ar também. O pesado vai pro chão. Tanto que em lugar, quando eles pulverizam vem aquele cheio... você sente o cheiro de agrotóxico no ar...".

Diretor Municipal de infra-estrutura.
}

Como forma de minimizar todos os problemas ambientais mencionados, os participantes citaram, principalmente, a conscientização da comunidade. Isso evidencia a necessidade e a importância em se desenvolver trabalhos de educação ambiental no local.

O grupo comentou também que, além da minimização dos problemas, é importante que sejam desenvolvidos projetos de recuperação de áreas que já foram degradadas.

\footnotetext{
"Agora eu acho que de todas essas coisas tem de ter uma atitude positiva de recuperação. Acho que a gente que trabalha, a gente tem que trabalhar com a possibilidade das formas de recuperação, tem lugar que já teve erosão, tem lugar que já teve...”.

Diretora Municipal de fomento ao turismo.

“Tem que recuperar, o rio, repovoar...".

Diretor Municipal de infra-estrutura.
}

Os participantes tiveram maior facilidade em visualizar a questão ambiental como um problema do que como uma potencialidade, mostrando maior conhecimento e pontos de vista mais diversos no primeiro caso. Talvez essa maior facilidade em tratar de problemas ambientais possa ser explicada pela proximidade dessas pessoas com o tema. Muitos deles, em função dos cargos públicos que exercem, costumam lidar com esses problemas em suas rotinas de trabalho. Além disso, os problemas listados 
referiam-se àqueles com impactos diretos no meio natural, enquanto que as potencialidades incluíram aspectos históricos e culturais, bem como elementos naturais já transformados ou úteis para os seres humanos.

São José do Rio Pardo possui, de fato, aspectos histórico-culturais bastante particulares (sendo o euclidianismo o mais acentuado deles) que constituem, indubitavelmente, potencialidades ambientais locais. De qualquer forma, possíveis problemas de ordem sócio-econômica existentes no município não foram citados.

\subsection{Biodiversidade: potencialidade e problema!}

O tema biodiversidade surgiu na etapa anterior apenas como uma potencialidade, $\mathrm{e}$ não como um problema, no município de São José do Rio Pardo. A partir dessa constatação, buscou-se aprofundar um pouco as discussões em torno desse assunto, com o objetivo de verificar quais concepções os participantes possuem do termo biodiversidade, qual a relevância desse tema em processos de educação ambiental, além de fazer um levantamento sobre quais aspectos da biodiversidade local são conhecidos como forma de subsídio para a elaboração da trilha. Para isso, foi utilizada a técnica de grupos focais.

De fato, houve uma certa dificuldade, especialmente nas primeiras reuniões, em conduzir um grupo focal, principalmente quando essa condução está aliada ao gerenciamento do equipamento de gravação. É imprescindível que haja uma pessoa responsável exclusivamente pelo equipamento, para que a pesquisadora, ou facilitadora do grupo focal, possa concentrar-se unicamente na atividade de condução da discussão em grupo.

Uma outra dificuldade verificada com o uso de tal técnica foi em relação à transcrição das discussões em grupo. Esta se apresenta muito mais trabalhosa do que a transcrição de entrevistas individuais, devido, principalmente, à distância das pessoas do gravador. Por essa razão, pesquisadores que se utilizam da técnica recomendam o uso de equipamentos específicos ${ }^{6}$ e até mesmo salas com isolamento acústico para a realização das reuniões.

Pelo fato de não haver equipamentos específicos disponíveis, optou-se pelo uso de 2 gravadores (um gravador digital e um gravador em fita cassete), que foram

\footnotetext{
${ }^{6} \mathrm{Um}$ dos equipamentos recomendados é o microfone omnidirecional, capaz de captar sons provenientes de todas as direções.
} 
posicionados em pontos opostos ao grupo de discussões, além da filmadora - o que apesar de assegurar uma maior clareza na transcrição dos dados, tornou essa etapa ainda mais trabalhosa, já que era necessário complementar as transcrições das falas dos participantes, utilizando-se os três registros. Ainda assim, a compreensão das falas dos entrevistados apresenta-se praticamente impossível em momentos nos quais várias pessoas se pronunciam ao mesmo tempo. Estima-se que houve uma perda de 10 a $15 \%$ de informações em conseqüência dessa dinâmica de discussão em grupo.

Embora tenha sido programado discutir em apenas uma reunião as questões previstas no roteiro (Apêndice B), isso não ocorreu, sendo necessário, portanto, dois encontros para tal discussão. Assim, o debate a respeito da questão da biodiversidade aconteceu efetivamente em dois momentos: na reunião realizada em 13 de julho de 2004 (na qual estavam presentes sete pessoas) em que finalizamos o levantamento de problemas e potenciais ambientais locais, e iniciamos a discussão sobre a biodiversidade; e durante o curso de formação de monitores ambientais (no qual estiveram presentes onze pessoas). Optou-se por finalizar essa discussão no momento do curso, em razão de algumas questões: primeiro pela dificuldade em reunir todos os participantes para finalizar essa discussão antes da data prevista para o curso, segundo porque a maioria dos integrantes do curso seria formada pelas próprias pessoas que já atuavam em todo o processo de elaboração da trilha; além disso, buscou-se, também, criar oportunidade para que os futuros monitores da trilha discutissem a respeito do tema central desta.

Quando questionados a respeito do que compreendiam por "biodiversidade”, após alguns segundos de silêncio, os participantes presentes na primeira reunião fizeram referência à diversidade natural, representada por diferentes espécies de seres vivos.

\footnotetext{
“Ah, são, são os diferentes conteúdos... da natureza, né? Eu acho que é assim, tipos, né? Animais, plantas, vegetais... Eu não sei muita nomenclatura das coisas porque eu sou artista, né?".

Diretora Municipal de fomento ao turismo.
}

\footnotetext{
"Bio é vida, né? Diversidade é vida. Tem vários tipos de... tanto animal, quanto vegetal, é tudo que...”.

Diretor Municipal de infra-estrutura.
}

Percebe-se que a concepção de biodiversidade dos participantes aproxima-se da definição de diversidade biológica, representada por diferentes espécies de seres vivos. Buscando confirmar essa concepção, já que não havia sido citado nenhum exemplo de 
diversidade sócio-cultural ou de inter-relação entre a diversidade estritamente biológica e ações humanas, eles foram questionados a respeito de quais locais a biodiversidade poderia ser encontrada. Mais uma vez, as respostas apontaram para biodiversidade como sinônimo de diversidade biológica, já que foram citadas, principalmente, as matas ou seja, as áreas naturais, como locais passíveis de se encontrar biodiversidade e sendo esta representada principalmente pela vegetação e fauna.

\footnotetext{
“Onde a gente pode encontrar biodiversidade? Nas matas... é, mas ... na zona rural, né? Na zona rural...”.

Empresário de uma agência de esportes de aventura.

"Aves, né?".

Coordenadora pedagógica.

“Muita coisa. Na zona rural vai ter plantas, tucano, ave... é o que mais tem”.

Empresário de uma agência de esportes de aventura.

“Vegetação, né?".

Diretor Municipal de infra-estrutura.
}

Apenas uma pessoa fez referência à área urbana (construída) como local possível de se encontrar biodiversidade, mas, mesmo neste caso, foram citados exclusivamente os aspectos naturais (diversidade biológica) presentes nessa área. Em nenhum momento foram citados aspectos de diversidade sócio-cultural.

\footnotetext{
“...mas...você encontra... maior diversidade, acho que na zona rural. Próximo da cidade você encontra alguns tipos de árvore, plantações, tem alguns animais assim mesmo que são domésticos, agora na zona rural você encontra muita coisa...”.

Estudante.
}

A partir dessa visão naturalista de biodiversidade, pode-se supor que a concepção que os participantes têm sobre meio ambiente também se aproxime da naturalista, ou seja, daquela que compreende como componentes do meio ambiente apenas os seres vivos e o meio físico-químico natural (REIGOTA, 1995).

Percebendo que o tema diversidade cultural não surgiu espontaneamente, foi perguntado o que eles entendiam por esse termo. Uma pessoa disse nunca ter ouvido falar em diversidade cultural, não sabendo, portanto, o que esse termo significava. Outra pessoa citou como exemplo a diversidade de culturas agrícolas, municipal e regional.

\footnotetext{
“Então tem essa, tem a cultura agrícola ... você pega aqui a nossa região, você pega Divinolândia é a batata, aqui é a cebola ... Aguaí é laranja, e tem cidade, assim, que justamente pelo tamanho tem vários tipos de cultura, quer dizer, se eu tô falando besteira...”.

Estudante.
} 
A diversidade cultural acabou sendo definida através de exemplos da própria cidade de São José do Rio Pardo, considerada pelos presentes uma cidade que sofreu influências culturais muito diversas, o que refletiu nas múltiplas expressões culturais hoje presentes: a Folia de Reis, o Caiapó, o Sanfoneiro, as festas juninas e até mesmo o euclidianismo.

“... a fundação da cidade... foi, assim, prioritariamente, os italianos com os mineiros, com os escravos... Depois... houve também uma influência da cultura japonesa,... sírio-libanês. Então assim, é um lugar que pela própria origem histórica já tem várias contribuições. São José, por exemplo, preserva a questão do folclore, bastante diversificado também. Então, quer dizer, eu entendo que a diversidade cultural é tudo isso, né? Caiapó, Folia de Reis, sanfoneiro, violeiro, festa junina todo mês, junina, julhina, agostina”.

Diretora Municipal de fomento ao turismo.

“O próprio Euclides da Cunha que é uma coisa cultural, estritamente cultural, quer dizer, é um cara veio pra cá e que reconstruiu uma ponte, que ficou amigo dos intelectuais, e que eles foram cultuando isso ao longo do tempo, transformaram isso numa semana de estudos que mobiliza em torno de 600 pessoas de fora, fora a própria comunidade..." Diretora Municipal de fomento ao turismo.

No segundo encontro, realizado durante o curso de formação de monitores ambientais, percebeu-se claramente que havia uma pequena modificação na concepção de meio ambiente por parte dos participantes. Se antes o meio ambiente era compreendido fundamentalmente em seus aspectos naturais, nesse momento ele já incorporava a dimensão do ambiente construído, chegando a ser definido por uma das pessoas como tudo aquilo que cerca o ser humano! Esta última aproxima-se de uma concepção antropocêntrica de meio ambiente, pois considera o ser humano como o elemento central do meio, e todos os outros elementos possuem a função principal de satisfazer os seus desejos e necessidades (REIGOTA, 1995).

Um aspecto bastante interessante a ser destacado é o fato dos participantes do curso terem citado também, as relações entre os diversos elementos, como sendo também componentes do meio ambiente.

“... eu acho que meio ambiente é tudo que está a nossa volta, onde que existe vida... no nosso planeta...eu acho que assim... no começo do curso a gente tava muito ligado à zona rural, a mata a floresta.... acho que agora mais no final a gente já... acho que ampliou um pouco mais...”.

Estudante.

“... tem o meio ambiente natural e acho que tem o meio ambiente urbano, né? Meio ambiente artificial também criado pelo homem, né?. As interações entre os elementos aí é diferente, né?".

Empresário rural. 
“Tudo é meio ambiente, né?”.

Diretor Municipal de infra-estrutura.

“É, não deixa de ser... meio ambiente não é só tudo o que está a nossa volta, mas a interação entre os elementos que compõem esse meio ambiente. Uma coisa interligada na outra”.

Empresário rural.

Embora na segunda reunião a concepção de meio ambiente já tivesse sido um pouco modificada quando comparada à reunião anterior, a concepção de biodiversidade ainda permanecia ligada aos aspectos naturais, mesmo quando identificada em ambientes construídos / urbanos.

“...[biodiversidade] é todo tipo de vida que faz parte do meio ambiente.... eu acho que ...tem vários tipos de biodiversidade, né? Cada ambiente tem o seu ... nessa praça tem a biodiversidade dela, na mata tem, lá no rio tem...".

Diretor Municipal de infra-estrutura.

"A biodiversidade, como o Alfredo falou, eu acho que é todo tipo de vida. Aqui tem biodiversidade".

Estudante.

“Uma coisa precisa da outra, né?...”.

Comerciante.

“A variedade das espécies, né?”.

Diretora Municipal de fomento ao turismo.

Um dos participantes declarou que, em sua opinião, não existia biodiversidade no ambiente urbano. Houve discordância por parte de outras pessoas e conseqüente debate. Por fim, todos concordaram que embora esteja presente em áreas urbanas/construídas, a biodiversidade é maior em áreas naturais, ou seja, nas áreas naturais existe maior riqueza de espécies. Esse consenso, mais uma vez evidencia uma concepção naturalista da biodiversidade, na qual esta é percebida como sendo composta apenas pelos elementos naturais do meio ambiente. Se a idéia de biodiversidade dos participantes incluísse também os aspectos sócio-culturais inerentes às populações humanas, os centros urbanos também seriam lembrados como locais passíveis de se encontrar biodiversidade.

\footnotetext{
"Eu já acho que nesse meio [construído] não existe biodiversidade. Eu acho que não". Estudante.

"Você acha que não existe aonde ? no urbano ?". Empresário de uma agência de esportes de aventura.
} 
“Não, existe. Não tô falando que não existe... a cidade foi um local construído. Existe ! Existe plantas... mas... a construção em si... não... O que eu entendo de biodiversidade é algum tipo de vida mesmo, vida, assim, qualquer tipo...".

Estudante.

“Existe mais biodiversidade na mata, na natureza, do que ... [na cidade], mas existe...”. Empresário de uma agência de esportes de aventura.

Quando indagados a respeito da relevância do tema biodiversidade em processos de educação ambiental, os participantes comentaram sobre a importância da educação para a conservação, e também da conservação de áreas naturais para serem utilizadas com finalidade educativa. Essa abordagem da educação ambiental é definida por Sorrentino (1998) como conservacionista. Ao mesmo tempo, percebe-se uma visão de educação como sinônimo de transmissão de informação, a qual Mayer (1998) chama de “educação ambiental sobre meio ambiente".

\begin{abstract}
"Mas acho que é importante você saber que espécie tem aqui, qual é a nossa, qual os tipos, qual que é essa diversidade, tanto de espécie animal, vegetal, meio cultural, a história, tudo isso faz parte da educação, o aluno tem que saber. É importante que ele tenha essa base. Tem que saber o que que tem aqui para ele poder, ele vai preservar, preservar o quê? Tem que saber quais são as espécies que nós temos para ele poder saber o que ele tem que preservar, o que que é importante, o que que não é”.

Coordenadora pedagógica.
\end{abstract}

"Só cuida quem conhece. Quem não conhece não cuida de absolutamente nada".

Diretora Municipal de fomento ao turismo.

Uma das participantes comentou a respeito da importância do contato com o meio natural como forma de dar significado ao aprendizado. Essa abordagem da educação ambiental é chamada de "educação ambiental no meio ambiente" por Mayer (op.cit.), e de "educação ao ar livre" por Sorrentino (op.cit.).

\footnotetext{
"Ah, é relação do cotidiano, no caso, relação da nossa história, né? Quando você relaciona com algo que está mais perto do aluno, mas fácil a aprendizagem. Constitui-se aprendizagem com facilidade, né? Porque quando você fala alguma coisa é muito distante. Se eles vão lá, eles vão ver, vão sentir, vão... Tem que significar. Quando a aprendizagem tem significado, acontece realmente, não é só uma memorização. Se você der a evolução só em livro didático, é como uma memorização que daqui a pouco você não lembra mais... tem significado pra eles quando tem a prática junto".

Coordenadora pedagógica.
}

Segundo Oliveira (2004), a concepção de educação ambiental tem como conceito subjacente o de meio ambiente. Se este é entendido como uma categoria estritamente biológica/natural, a educação ambiental tende a ser compreendida como ecológica ou conservacionista (este caso). Se o meio ambiente fosse entendido como uma categoria 
sociológica mais ampla, a educação ambiental tenderia a incorporar outras dimensões, tais como social, cultural, econômica, entre outras, além da dimensão ecológica. Além disso, os conceitos de meio ambiente, educação ambiental e biodiversidade podem se apresentar pouco claros e controversos, já que são socialmente construídos e influenciados por ideologias, tendências e interesses diversos.

\footnotetext{
"Eu acho que a educação ambiental... é todo tipo de informação, assim, que é passado pra gente a respeito da biodiversidade... da forma de conscientização, de educação, de preservação, de interação também como você falou, com o homem, como que nós nos adaptamos ao meio ambiente... educação é tudo isso assim que fala do meio que a gente vive”.

Estudante.

“... a gente colocou também que é tudo que vai nos ensinar a manter e preservar a questão da qualidade de vida...”.

Diretora Municipal de fomento ao turismo.
}

Embora sendo compreendida como informativa, os integrantes consideraram que a educação ambiental constitui-se num processo longo e complexo, no qual as mudanças somente são observadas em gerações futuras. Eles também apontaram o fato das gerações atuais estarem mais conscientes em relação à conservação, já que em gerações passadas, algumas práticas danosas ao meio ambiente, tais como a caça e a pesca indiscriminada, eram mais comuns.

\footnotetext{
“Médio a longo prazo... [educação ambiental] não se faz da noite para o dia não...eu acho que se faz no ritmo de gerações”.

Diretor Municipal de infra-estrutura.

"A geraçãode nossos pais, principalmente do meu pai, assim, era predadora, né? Nossa geração já deu uma melhorada, a de vocês já... cada vez mais... Cada geração vai melhorar muito mais...".

Diretor Municipal de infra-estrutura.
}

"Antigamente quem falava isso [conservação] era taxado de louco, 'aquele cara lá não bate bem, só fala abobrinha'...”.

Diretor Municipal de infra-estrutura.

Um dos participantes exemplificou essa situação através de espécies de aves que são facilmente encontradas atualmente, mas que há pouco tempo atrás não eram vistas.

\footnotetext{
"É muito comum você ver vários tipos de passarinho que tinha uma época que você não via mais... Tucano, aquelas pombas do mato, aquela pomba grande que eu não via muito também. Gralha, você vê muito, maritaca, periquito...".

Diretor Municipal de infra-estrutura.
} 
Com exceção da fala acima descrita, na qual foram exemplificados alguns representantes da diversidade biológica local, percebeu-se que houve uma certa dificuldade por parte dos integrantes do grupo, em citar esses exemplos. Talvez isso possa ser justificado pelo fato de nenhum dos presentes ter alguma formação mínima na área; ou ainda, pela pouca ocorrência de estudos sistemáticos de levantamento de diversidade biológica local. Mesmo esses poucos estudos costumam ser de difícil acesso aos leigos, principalmente pelo fato de sua linguagem ser muito específica

Além disso, devido à perda de contato das pessoas com o meio natural ao longo dos anos, cada vez mais estas perdem a capacidade e a sensibilidade de perceber os ciclos naturais, e, conseqüentemente, de identificar possíveis modificações no seu entorno.

Embora na segunda reunião a educação ambiental ainda tenha sido concebida como informativa, o grupo considerou o tema "conservação da biodiversidade" bastante importante para ser debatido nesses processos. Alguns até explicitaram que sentiram dificuldade em falar sobre esse tema devido à falta de informação e conhecimento sobre o assunto.

\footnotetext{
"Se a gente continuar nesse desequilíbrio, nessa falta de discussão sobre o assunto a gente vai continuar ignorando. Eu acho que a gente precisa estar discutindo, quer dizer, aqui, todo mundo que tá aqui tem estudo e nós temos dificuldade de estar tratando... Se a gente não discutir sobre isso aí, como é que a gente vai alterar essa realidade? Se a gente mesmo que entende não entende... a gente tem uma dificuldade de precisar com exatidão. A gente identifica que é importante, intui que deve preservar, mas a gente não sabe o caminho. Então a gente fica todo mundo se enroscando, assim, né?”.

Diretora Municipal de fomento ao turismo.
}

A relação estabelecida pelo grupo entre ser humano e biodiversidade é uma relação de pertencimento. Em sua concepção, o ser humano faz parte do meio ambiente e também é parte da biodiversidade, não sendo capaz de sobreviver sem os elementos naturais do meio.

Apesar de estabelecida essa relação, a diversidade cultural não foi citada espontaneamente. Percebe-se, então, que a biodiversidade é compreendida, pelos integrantes do grupo, em um sentido estrito, ou seja, apenas como uma diversidade inter-específica. Outras dimensões da biodiversidade, como, por exemplo, a diversidade intra-específica, genética, de ecossistemas, paisagens e populações não foram consideradas. Também não foi citada a criação de biodiversidade a partir de ações humanas, tais como a transgenia e outras técnicas de manipulação biológica e genética. 
"É que a gente acostumou muito ver a biodiversidade a questão de mata... O marketing que foi feito em cima disso foi muito pra esse sentido... Então talvez a gente tenha mais dificuldade pra visualizar isso... [biodiversidade] é todo tipo de vida, é a variedade de vida, variedade de espécies e nós também somos espécies, tem uma série de outras espécies talvez até não visíveis... Mas que estão aí compondo o todo da cadeia... Que é uma cadeia... Aliás, fomos os primeiros a estragar tudo”.

Diretora Municipal de fomento ao turismo.

Analisando o comentário acima, observa-se a idéia de que o ser humano tenha causado, ao longo dos anos, diversas interferências no meio ambiente, podendo ser considerado o principal causador dos problemas ambientais atuais (entre eles, a perda de biodiversidade). Assim, outra relação estabelecida pelo grupo entre o ser humano e a biodiversidade seria de responsabilidade do primeiro para com as perdas e/ou perturbações ocorridas no segundo.

Essa responsabilidade pelo desequilíbrio ecológico e pela perda de biodiversidade ao longo dos anos é atribuída ao ser humano dito civilizado. O grupo acredita que as comunidades tradicionais e indígenas tenham maior integração e respeito com o meio onde vivem.

\footnotetext{
"Isso aí a gente às vezes fala que os caras desmatavam e tal... eles tinham um conceito de preservação que eles tiram todo o homem daquela comunidade e aí deixa só um representante que nem os pais do cara lá, deixa só o Zé Colméia lá... Mas quem destruiu não foi o índio que vivia naquele parque porque a comunidade original de muitos desses lugares, ela trabalha dentro do próprio ciclo da natureza e de forma equilibrada... Mas a destruição foi tão grande e a nossa falta de informação é tão grande que de repente os caras tiraram a pessoa que era de lá que trabalhava de uma forma mais preservada e desequilibraram também o meio ambiente... Além de desintegrar aquela figura humana que vivia lá, perdeu a sua função. Só sabia plantar ali, colher, sabe aquele negócio? E eles perderam todo um processo cultural”.

Diretora Municipal de fomento ao turismo.
}

Embora os participantes tivessem dito que o ser humano pode ser responsabilizado pelos problemas ambientais enfrentados na atualidade, inclusive a perda de biodiversidade, um dos presentes comentou que esta também pode ter causas naturais: secas, enchentes, queimadas, vendavais, entre outros.

Ainda segundo o grupo, já que a falta de consciência dos seres humanos justifica os danos ambientais por eles causados, inclusive a perda de biodiversidade, o papel da educação ambiental consiste em promover essa conscientização. 
"Pelo que eu entendi aqui na nossa explicação de biodiversidade com educação ambiental... Nós fazemos parte da biodiversidade e também foi discutido aqui quem que é o grande causador desse desequilíbrio, desse desmatamento: somos nós, entendeu. Então, assim, por isso que é importante a educação ambiental: ela só começa a partir, assim, da gente... A relação do tema biodiversidade com educação ambiental. Essa educação ambiental ela só vai começar a partir do momento que a gente tiver consciência que a gente é o grande causador desse desequilíbrio, desse desmatamento. Então, assim, é a relação que eu to fazendo, entende, de biodiversidade e educação ambiental...”.

Estudante.

Os integrantes também comentaram que nem todas as pessoas possuem as mesmas responsabilidades em relação aos problemas atuais, entre eles a perda de biodiversidade.

Mas foi dito que todos ali, em função das atividades que exercem ou dos cargos que ocupam, possuem a responsabilidade de difundir ideais e práticas conservacionistas.

\begin{abstract}
“... eu acho que ... nós estamos aqui para nos sensibilizar com relação a isso. O único jeito da gente ficar sensibilizado é ficar discutindo. Porque na verdade não fui eu... [você ou ele] que foi lá e pôs fogo na mata, fomos lá, passamos a serra elétrica... a gente tem que tomar uma ação, assumir a responsabilidade de espécie, você entendeu? Não fomos nós, concretamente, que fomos lá e prejudicamos a natureza. Até pelo contrário: muitos de nós fala assim 'olha que absurdo, tá derrubando esgoto no rio, não estamos preservando, não sei o que' e, ao mesmo tempo, a gente se põe impotente com relação historicamente a esses fatos... A gente tem que sensibilizar porque é um assunto que não está ainda completamente discutido, temos que discutir isso dentro da nossa realidade que é São José do Rio Pardo e é por isso que eu acho importante estar fazendo esse projeto ... A importância da gente estar discutindo aqui é que esse grupo vai ampliar essa discussão para outros grupos”.
\end{abstract}

Diretora Municipal de fomento ao turismo.

Um participante discordou da colocação anterior, argumentando que, de certa forma, todos nós somos responsáveis pelos danos ambientais, já que fazemos parte de um sistema econômico essencialmente nocivo ao meio ambiente.

\footnotetext{
"Acho também que o próprio sistema de produção hoje ele enfrenta muito o interesse econômico, né? Então, por isso que é tão difícil você... às vezes você tem até consciência, mas pra você transformar... Na verdade vai ter que transformar pra ser ecologicamente correto de verdade, né? Tem que transformar todo um processo... o sistema de produção, o processo de produção... e vai influenciar economicamente também. Porque o sistema implantado que é muito mais destruidor, digamos assim, é muito mais barato, né?... Do que o ecologicamente correto".

Empresário rural.
}

O grupo também acredita que os valores atuais de felicidade e bem estar estejam muito ligados aos valores de posse.

\footnotetext{
“Acho que uma das preocupações é com posse, né?... pra sobreviver, né? Eu vou ter uma casa mais que a dele, a minha é maior que a dele...".

Diretor Municipal de infra-estrutura.
} 


\begin{abstract}
"Isso que você tá falando... em relação ao nosso país aqui a gente é influenciado pelos Estados Unidos. Ali é o consumismo... é o descartável. Essa é a filosofia que nós temos. A Europa já é totalmente diferente porque lá eles já passaram por 2 guerras mundiais. Eles foram palco da guerra. Eles têm problemas de água... de energia. E é por isso que lá existe essa... sabe, eles já sentiram na pele o que é faltar... aqui o que a gente absorveu foi a cultura do consumismo americano, do desperdício, do descartável”.
\end{abstract}

Estudante.

“... a gente é influenciado, mas é o que eu falei: nós somos um grupo de formadores de opinião. Então, de repente os supermercados podem voltar a ter aquelas sacolinhas de, não sei do que, papelão, papel reciclado porque existe essa outra possibilidade, né? Mas vai depender também da...".

Diretora Municipal de fomento ao turismo.

"Posso dar um exemplo? Meu pai tem uma distribuidora de água. Todo garrafão de água vem com lacre e uma tampa. Eu não jogo nada... eu não consigo, eu tenho vergonha de mim mesmo de pegar o papel, assim, jogar na rua... E eu andava às vezes na cidade e via... o rótulo e a tampa. Eu ficava com vergonha porque eu sabia que tava saindo da minha empresa ... hoje eles [os funcionários] juntam e guardam. No final de três ou quatro meses a gente vende as tampinhas e eu dou o dinheiro pra eles... Aí eles tão recebendo dinheiro da tampinha, agora eles não jogam nem no lixo eles não jogam, eles guardam... Quer dizer, foi um trabalho que não foi fácil. Eles tiveram que ganhar o dinheiro da tampinha pra não fazer mais isso".

Empresário de uma agência de esportes de aventura.

Apesar de terem dito que o ser humano pode ser responsabilizado pelos problemas ambientais atuais, nenhum dos participantes soube afirmar se a biodiversidade está realmente se perdendo. Eles acreditam que a preocupação com a conservação tenha aumentado muito nas últimas décadas, e que atualmente não é difícil encontrar iniciativas relativas à conservação nas escolas, em órgãos públicos e até mesmo na mídia.

\footnotetext{
"Eu acho que o exército de hoje tá bem maior que antigamente pra defender essa terra, mas ainda não sei se a gente tá conseguindo... se já chegou próximo do equilíbrio. Mas se você pegar, uns tempos atrás ninguém discutia isso, ta preocupado com isso, hoje e agora com essa educação dessa meninada que ta surgindo, dessa geração mais nova, vai aumentar muito mais porque desde pequenininho tá pondo na cabeça a importância... de primeiro não existia isso. A gente era da geração de matar passarinho, essas coisas, detonar... nossos pais eram predadores em potencial, tanto histórico...qualquer tipo de coisa eles... E agora nós já estamos melhorando muito, nossos filhos vão melhorar mais. Vai chegar uma hora que vai, vai virar o jogo... não sei se já ta empatando né? Mas ta chegando perto".
}

Diretor Municipal de infra-estrutura.

"A gente acha, assim, que a ... ela consegue ser mais lenta, a destruição é mais rápida do que a possibilidade de conservação. Então eu não sei bem dizer como é que é, tá esse jogo".

Diretora Municipal de fomento ao turismo.

“... eu tenho dúvida, assim, como é que tá essa nossa disputa, entendeu? Se as monoculturas, a destruição e tudo mais, não está sendo mais rápida do que a preservação da biodiversidade. Mas, eu acho que é o caminho que a gente tem que caminhar, quer dizer, cada um de nós fazer a sua parte como cidadão e quanto mais consciente, buscar 
para interagir em projetos como esse. Acho que isso é o que a gente pode fazer, né?”. Diretora Municipal de fomento ao turismo.

"Um exemplo essa quadra aqui era um jardim artístico, com umas árvores centenárias, que era uma beleza. Na época que destruiu isso aqui, só tinha uma pessoa que defendeu que era um jornalista e todo mundo achava que era louco, ele era não sei que. Hoje ninguém destruiria mais isso aqui. Não ia mais conseguir respaldo por aî”.

Diretor Municipal de infra-estrutura.

Mesmo sem saber ao certo se a biodiversidade está se perdendo, os participantes presentes acreditam que ela deva ser conservada por diversas razões, que vão além do potencial educativo citado anteriormente. O primeiro argumento utilizado foi $\mathrm{o}$ egoístico/utilitário (HAGVAR, 1994), também chamado de antropocêntrico por Oksanen (1996), por meio do qual a conservação da biodiversidade é baseada na sua utilidade potencial de acordo com interesses e desejos humanos. Oksanen (op.cit.) definiu essas categorias de argumentos com base na maneira como a preservação da biodiversidade é justificada moralmente em textos de ética ambiental. Embora suas conclusões não sejam favoráveis a considerar a biodiversidade como um valor intrínseco, este deve ser atribuído aos seus vários elementos, que devem ser preservados em benefício de todo o sistema natural.

\footnotetext{
"Turisticamente e econômico".

Diretor Municipal de infra-estrutura.

“... a sobrevivência, por exemplo, do próprio negócio do... se ele não tiver preocupação com a qualidade de vida, com a manutenção das matas, da qualidade de vida, tudo mais... daqui um tempo ele não tem... então é uma opção de trabalho, uma opção de vida, é uma filosofia”.

Diretora Municipal de fomento ao turismo.
}

Outro argumento citado foi o ecológico (HAGVAR, op.cit.), também chamado de ecocêntrico por Oksanen (op.cit.). Neste, a conservação da biodiversidade é sustentada na sua função ecológica de manutenção do equilíbrio do sistema.

\footnotetext{
“Ambiental também... Ué porque quando está preservando tudo que nós falamos aqui, o desmatamento, se você num... vai acabar perdendo o equilíbrio ecológico, ué. É um trabalho ambiental num outro sentido, eu acho".

Coordenadora pedagógica.

"Eu acho que é uma coisa assim, a educação no sentido da formação do ser, sabe como é que é? Não só educação formal, educação de escola, é a educação do cidadão, como um ser que interage com o global, entendeu?... Porque não é só essa coisa imediata, não é só o cara com o Rio Pardo, com aquela arvrinha, com aquela matinha, né? É o ser com o global. Aquela mata que tem a ver com o Estado, tem a ver com o país, que tem a ver com o planeta, né? E que aí vai, a gente espera, né? Que vai tornar isso uma consciência maior, né?".

Diretora Municipal de fomento ao turismo.
} 
Um terceiro argumento utilizado pelos participantes foi no campo da ética, podendo ser considerado como uma aproximação da categoria "ético", definida por Hagvar (1994), segundo o qual a biodiversidade deve ser conservada pelo seu valor intrínseco e pela responsabilidade do ser humano com as futuras gerações.

“... a natureza ensina muito pra gente a questão do respeito também com o outro, né? Que é uma coisa muito interessante e importante... Quando você aprende a respeitar a natureza, você aprende a respeitar uma outra coisa, uma outra pessoa, né? Você tem que fazer aquilo não só por você, né? Você pode até não utilizar aquilo... vai respeitar aquilo em função de outras pessoas que vão vir e que vão precisar daquilo, que vão se utilizar daquilo, né?".

Diretora Municipal de fomento ao turismo.

"Eu acho que a gente vai preservar pela nossa própria responsabilidade, que a gente pode também não estar sabendo falar completamente, sobre o que que é biodiversidade, sobre tudo isso que você está nos perguntando, mas eu acho que a gente como espécie tem responsabilidade de preservar...”.

Diretora Municipal de fomento ao turismo.

Por fim, o grupo concluiu que a biodiversidade deve ser conservada por todas essas razões: econômicas, ecológicas e éticas.

\begin{abstract}
"Então, acho que a gente tem essa responsabilidade. Responsabilidade mesmo, de espécie, sabe. É como eu falei, acho que a gente recebe as coisas... mesmo com a questão da educação. Você recebe conhecimento você passa a ter a responsabilidade sobre esse conhecimento que você recebe. Você passa a ter responsabilidade de passar para os outros. Porque você recebeu.... não é uma coisa pra você guardar dentro de você, é uma coisa pra você passar pra frente. Então, o conhecimento, a preservação, tudo isso eu acho que são responsabilidade mesmo”.

Diretora Municipal de fomento ao turismo.

“... a gente também não conhece São José do Rio Pardo, e essa questão da sua peculiaridade, né, precisamos saber, para que a gente também exerça essa nossa responsabilidade de preservação. Pra que é? É pra tudo: é pra nós, pras outras gerações, é pra preservação da qualidade de vida, é pra preservação do negócio... é pra preservação, sei lá, dos tataranetos, é de tudo, a nossa própria... Nós não vamos ter água se a gente continuar desmatando, imaginem! Imagina a gente morrendo de sede...". Diretora Municipal de fomento ao turismo.
\end{abstract}

Com relação ao problema da água, já anteriormente mencionado, foi discutido se essa preocupação seria mesmo para o futuro. Algumas pessoas comentaram que a falta d'água em algumas regiões já é um problema atual.

\footnotetext{
“Essa preocupação é pro futuro, né? Pra nós não vai acontecer isso de falta d'água, mas se a gente não começar a pensar agora, a próxima geração vai ter. Então, acho que já faz parte dessa... se a gente pegou uma coisa bem feita, mas temos a obrigação de entregar bem feito. Se pegou errado, temos a obrigação de consertar pra entregar pra próxima geração...”.

Diretor Municipal de infra-estrutura.
} 
“Na verdade já tem cidade que estão pegando água... não aqui, mas...".

Diretora Municipal de fomento ao turismo.

“Mas em 10 anos dá pra ficar sem água, se não cuidar”.

Empresário rural.

"São Paulo tem essa preocupação, eu tô falando que São José não tem. São Paulo que se vire, São José tem água... Pode piorar, mas não vai acabar...”.

Diretor Municipal de infra-estrutura.

"Mas é o tal negócio: lá acabou, eles vão vir aqui buscar, ué, eles vão vir aqui buscar. Esse é o problema: a gente tem, né? A gente não precisa, vamos dizer, São José do Rio Pardo ta tranqüilo sobre esse assunto. Mas se lá acabar, eles vão ter que ir buscar, né? Aonde? No lugar mais perto...".

Produtor rural.

"É o negócio do futuro, vender água”.

Diretora Municipal de fomento ao turismo.

Os integrantes concordaram que um planejamento adequado das atividades humanas seja essencial para a conservação do meio ambiente e da biodiversidade.

"Você falou a palavra-chave agora: planejar. Isso é uma coisa que eu acho que também faz parte da evolução. O homem aprender a planejar. Porque não é que ele não possa conviver com a natureza que obrigatoriamente ele vai destruir. Não é que a gente aqui na cidade vai obrigatoriamente ter que destruir. A questão do planejamento, seja na área que for, tendo planejamento não...”.

Diretora Municipal de fomento ao turismo.

"Você planejando, você cria as regras".

Diretor Municipal de infra-estrutura.

“Por exemplo, nós vamos lá na Fazenda da Tubaca, nós vamos fazer essa trilha. É um produto turístico... Pode ser outra coisa, mas é um produto turístico. Você vai levar um grupo na mata da Tubaca que está cercada. Por que ela está cercada? Porque já foi catalogada... Então, há um planejamento. Alguém fez aquele levantamento ... as árvores são marcadas. A gente tava morrendo de medo que o Eduardo não fosse autorizar. Ele falou assim: 'não, era tudo o que eu queria era um projeto desse tipo, pra que? pra dar continuidade ao que foi feito', quer dizer, então tá sendo feito um planejamento. Ele ouviu o que as meninas expuseram e aceitou que seja feito lá. Quer dizer, ele vai estar abrindo a fazenda dele, um lugar fechado, pra estar oferecendo pra comunidade o produto. Ninguém mais vai ter que pular a cerca pra entrar na mata da Tubaca. Vamos poder passar pela porteira”.

Diretora Municipal de fomento ao turismo.

O grupo também discutiu um pouco a respeito da questão da coerência entre o discurso ambiental e a prática. Este acredita que as pessoas ainda queiram tirar vantagens das diversas situações e buscam atitudes mais cômodas no seu dia-a-dia, como forma de não assumir sua parcela de responsabilidade para com as questões relativas ao meio ambiente. 
“Eu acho que a gente olha sempre pro lado... sei lá se é negativo ou lado errado...você fala pra pessoa 'não joga o lixo no chão, não joga o lixo no chão' aí você vê lá na Tubaca... que nem pescar... ah, eи não vou soltar porque o outro não solta... A gente sempre quer burlar, né? ... 'ah isso aqui não tá certo... mas todo mundo faz'... É uma coisa natural, geral, né? A pessoa sempre copia o errado nunca copia o certo”.

Diretor Municipal de infra-estrutura.

“Isso ainda é, infelizmente, aquela .... de tirar vantagem, de levar vantagem”.

Diretora Municipal de fomento ao turismo.

“É uma coisa de disciplina ... é uma postura. É a sua filosofia de vida, quer dizer, você aceita que você vai... passar a fazer aquilo. Você passa a fazer, independente de está se preocupando se o outro tá fazendo ou não. Porque a gente tem que ser modelo, achar que é modelo, né? Então você é modelo, alguém tá vendo, alguém vai aproveitar isso que você ta fazendo: a sua maneira de falar... a sua maneira de fazer. Porque como é que você vai ensinar se você não faz, né? ... Agora a coerência do nosso discurso aí é uma coisa pessoal, é uma coisa que eu acho que cada um de nós tem que buscar... A gente acho que busca o mais fácil, o mais cômodo".

Diretora Municipal de fomento ao turismo.

"Eu acho que o pessoal foge da responsabilidade... porque se eu jogar o papel aqui na rua... Alguém vai ter que ir lá limpar. Esse papel vai causar alguma coisa. Então, eu acho que é fugir da responsabilidade. Joga porque tem o cara que vem varrer. Se eu não jogar, não precisa ninguém varrer. Já vai estar limpo, então eu acho que fugir um pouco dessa responsabilidade. Uma pessoa vai acampar: ela tem que ser responsável pelo lixo que ela leva...”.

Empresário de uma agência de esportes de aventura.

“Eu vou dar um outro exemplo... Vou voltar pra questão do turismo. O turista vai à cidade então, e ele acha que ele não tem responsabilidade sobre aquela cidade. Por quê?? 'Cara, eu passo ali um fim de semana, não sou eu que estou destruindo a cidade, não é o lixo que eu vou deixar... que vai depredar a cidade porque a minha estadia ali é muito pouca'... ela está acostumada de se isentar dessa responsabilidade porque ela acha que aquela fração de tempo da vida dela é muito pouca pra ela ter que assumir a responsabilidade... A gente passa por esses momentos achando que aquilo é muito insignificante dentro do problema total. Então, a gente se libera dessa responsabilidade...".

Diretora Municipal de fomento ao turismo.

O grupo também fez algumas relações entre os aspectos de diversidade biológica e cultural presentes na região, mais uma vez ressaltando a importância do rio Pardo, como elemento natural preponderante da ocupação humana, do uso do solo, da história e dos costumes locais.

\footnotetext{
"Desde a origem da cidade, da história da origem da cidade. Os Caiapós... era uma tribo que existia aqui. A proximidade com Minas, a nossa influência mineira. Produção de café e não cana-de-açúcar, por exemplo... Tem a estação ferroviária porque tinha a plantação, fez a ponte porque tinha que vir o café para ir para a estação ferroviária para ir pra Santos. Depois vieram os italianos porque houve a abolição da escravatura aí, então os italianos vieram pra produzir. Eles trouxeram toda a cultura italiana”.

Diretora Municipal de fomento ao turismo.
}

“O próprio jeito de construção aprendeu com os italianos, né? O barro e o cimento”. Comerciante. 
“... a nossa origem, a questão cultural é total a diferença. O fato de ter uma ponte importante, o fato de ter o rio que corta mesmo a cidade é fundamental. A pesca é conseqüência de haver o rio no centro da cidade".

Diretora Municipal de fomento ao turismo.

"Normalmente a localização de uma cidade é em função de rio, e tal...". Empresário rural.

"Que corta o centro todo não são todas as cidades. Tem proximidade mas como São José que você olha do Cristo, a cidade ... se esparrama ao longo do rio, né? Ela vai sendo meio comprida, né? Porque ela vai indo no sentido. Os bairros populares estão indo pra Mococa, estão avançando as áreas rurais, né? A questão da cidade, do urbano estar avançando na questão rural”.

Diretora de fomento ao turismo.

Apesar de inicialmente a biodiversidade ter sido considerada um potencial ambiental local, percebe-se uma contradição por parte dos participantes: se a biodiversidade é entendida por eles como sinônimo de diversidade biológica, como ela pode ser potencial, uma vez que foram citados vários problemas ambientais que influenciariam diretamente sobre ela? Por outro lado, embora citados como potencialidades ambientais, os aspectos sócio-culturais não foram inclusos na definição espontânea de biodiversidade.

De fato, o município possui uma diversidade cultural bastante relevante e particular, e este aspecto não pode ser ignorado em processos de educação ambiental, já que os problemas ambientais, na maioria das vezes, têm causas comuns aos problemas humanos. 



\section{A CONSTRUÇÃO COLETIVA DA TRILHA INTERPRETATIVA DO MEIO}

O presente capítulo descreve a intervenção educativa em si, ou seja, o processo de construção coletiva da trilha interpretativa do meio, que compreendeu as seguintes fases:

- a escolha do local;

- a elaboração prévia do roteiro;

- as revisões do roteiro realizadas com o grupo de participantes de São José do Rio Pardo, antes e depois das visitas das crianças à trilha;

- a avaliação da atividade, feita pelas crianças e pelos integrantes do grupo;

- a avaliação que o grupo fez do processo como um todo.

\subsection{Elaboração}

A trilha interpretativa do meio foi elaborada juntamente com os participantes, a partir dos temas considerados relevantes no contexto local.

Alguns dos objetivos da trilha interpretativa do meio foram: possibilitar a reflexão e a discussão das questões ambientais locais e regionais mais relevantes; valorizar o conhecimento local, bem como incentivar ações coletivas e individuais de recuperação, melhoria e/ou conservação das condições ambientais locais.

Percebeu-se logo de início que havia um grande interesse e desejo das pessoas em participar desse projeto. Assim, as expectativas delas em relação à trilha foram incorporadas como objetivos desta, além daqueles propostos pela pesquisadora. Os participantes também tomaram parte da escolha do local da trilha, sugerindo diversas áreas para a implantação desta.

Eles também fizeram várias sugestões, tanto em relação aos temas e assuntos a serem abordados na trilha, quanto em relação a assuntos de ordem mais prática, tais 
como: quais turmas deveriam ser envolvidas no trabalho, duração da atividade, meios de transporte, entre outros.

Como dito anteriormente, os diversos momentos da construção coletiva da trilha foram caracterizados por diferentes graus de participação dos envolvidos. A fase de elaboração do roteiro preliminar da trilha foi a menos participativa do processo todo. Nela, a pesquisadora, utilizando-se dos temas levantados nos diagnósticos, bem como das sugestões dadas pelos participantes, elaborou um roteiro que fosse pautado pelos princípios e diretrizes da percepção e da interpretação ambiental.

A etapa seguinte, que compreendeu o curso de formação de monitores, a implantação da trilha e a avaliação desta pelos participantes, também foi bastante participativa, já que todos puderam expor suas idéias e debatê-las entre si, aprimorando, dessa forma, o roteiro prévio da trilha.

Embora na concepção do projeto, a etapa de elaboração da trilha se iniciasse após o diagnóstico local, na prática, ambos ocorreram de forma concomitante. Os participantes deram sugestões ao roteiro da trilha, comparando os problemas municipais com aqueles passíveis de ocorrer na trilha a partir do uso público, sendo que também foram elaboradas revisões e adaptações do roteiro pré-estabelecido.

\subsubsection{As expectativas dos participantes em relação ao projeto}

Durante os primeiros contatos com os participantes locais, e antes mesmo de termos definido o lugar para a implantação da trilha, percebeu-se que as expectativas de alguns em relação ao projeto era de construirmos uma trilha que tivesse, além da finalidade educativa proposta pela pesquisadora, uma finalidade turística. Outra expectativa, detectada logo nos primeiros encontros, era referente a darmos subsídios a eles para que pudessem construir outras trilhas no futuro. Essas expectativas foram confirmadas durante a nossa primeira reunião.

\footnotetext{
"A minha expectativa é que com isso a gente possa conseguir ter um produto turístico, também, legal pra São José e uma possibilidade de trabalhar a questão da preservação”. Diretora Municipal de fomento ao turismo.
}

Uma perspectiva bastante importante em um trabalho que tenha a intenção de ser participativo e que foi identificada logo na primeira reunião, é a perspectiva de troca, de possibilidade de benefícios oriundos do trabalho, a todos os envolvidos. 
“...trabalho com Esporte e Aventura e a minha expectativa é a melhor possível para ajudar vocês e também nos ajudar a fazer esse projeto”.

Empresário de uma agência de esportes de aventura.

“... a minha expectativa é poder ajudar vocês a construir esse trabalho e, ao mesmo tempo, transformar essa trilha num projeto, num produto turístico ... nossa tentativa, nesse sentido, tem sido constante ... a grande preocupação de todo mundo é falar que o euclidianismo não é o turismo de São José do Rio Pardo, e na realidade, a nossa preocupação deve estar voltada para o turismo de aventura, é relacionado com natureza... mas, tem sido, na minha opinião muito difícil. ... na verdade ninguém tem esse interesse, a não ser nós e a... [agência de esportes de aventura]".

Secretário Municipal de Turismo.

Surpreendentemente durante a primeira reunião, um dos participantes com quem a pesquisadora já havia conversado previamente sobre o projeto, e que na ocasião mostrou-se bastante interessado, disponibilizando material de consulta para a pesquisa e sala para as reuniões, revelou-se um tanto reticente ao trabalho de educação ambiental. Segundo ele, em experiências anteriores, ele pôde observar o caráter pontual e descontínuo de tais intervenções.

"Em termos de expectativa eu não vejo assim como uma possibilidade de integrar os diferentes seguimentos uma questão de projeto ambiental onde o turismo rural seria um dos caminhos porque, na realidade, o que eu sinto aqui é, quando eu estive no Caíque, dando umas palestras lá, o que eu vejo são atividades pontuais, sem continuidade. Eu vejo que a questão da educação infantil não tem um programa dinâmico para todas as faixas etárias... é uma campanha de garrafa pet, ou disso ou daquilo e sem continuidade..." Engenheiro Agrônomo da Secretaria de Agricultura.

Outro participante também se queixou do caráter pontual e descontínuo das ações educativas relacionadas ao tema ambiental.

\footnotetext{
“Esse assunto é tratado pontualmente, não tem uma seqüência.... então as pessoas têm um conhecimento vago dessas coisas, vem um grupo de dá uma informação, vem outro grupo e dá outra informação...então a escola precisaria se preocupar em fazer isso de uma maneira perene".

Secretário Municipal de Turismo.
}

A própria concepção do projeto de forma participativa reflete certa preocupação com essa descontinuidade das ações educativas de cunho ambiental, e já se constitui em uma tentativa de garantir a sua sequiência quando não houver a presença da pesquisadora.

Um fato bastante positivo foi o de que todas as dez pessoas convidadas previamente para a primeira reunião compareceram - além do administrador da Fazenda 
Tubaca (local onde desejávamos implantar a trilha) e da coordenadora da escola municipal Stella Maris Barbosa Catalano, cujo convite foi feito pelos próprios integrantes do grupo. Isso mostra a relevância do tema e o interesse dos cidadãos em conhecer e participar do projeto.

A coordenadora da escola municipal mostrou-se bastante feliz e interessada na proposta da trilha e, juntamente com a diretora da escola - ambas já tinham participado de projetos semelhantes - demonstrou interesse em criar oportunidades para os alunos participarem de atividades educativas relativas à questão ambiental.

“... sou professora da rede municipal... porque eu nem sei do que se trata, né? Daí ele me adiantou alguma coisa e eu achei que veio de encontro com o que a gente trabalhou com os alunos na escola né? ... e eu fiquei feliz, né? Eu vim sem saber direito do que se tratava mas eu acho que eu tô no ambiente certo, que a gente possa fazer um projeto lá porque a gente tá tentando fazer um projeto desse desde o ano passado, a gente trabalha muito na busca da preservação...”

Coordenadora pedagógica.

Por fim, o comentário a seguir resume as expectativas dos participantes em relação ao projeto. A elaboração de uma trilha com finalidades educativa e turística daria continuidade a um trabalho de conservação já iniciado na Fazenda Tubaca.

\footnotetext{
"Eu acho que, na verdade, isso o que vocês estão querendo fazer é o coroamento de um trabalho porque, por exemplo assim, a família ... vem há muito tempo preservando essa área. Então a gente fala muito de desmatamento ... então a pessoa preservou, conseguiu um trabalho onde foram catalogadas as espécies, e a mata tá fechada esperando exatamente o coroamento desse trabalho que é ... isso que vocês estão propondo, é finalizar tudo isso que já foi feito, a preservação, esse levantamento das espécies e retornando isso pra comunidade... em forma de conhecimento, de dinâmica que possa trazer esse conteúdo, essa valorização da mata, de como é que ela foi formada, da história, de tudo isso que vai estar envolvido com a história das pessoas como cidadãos riopardenses, né, que vão estar no contexto de um planeta... Enfim, então é todo um coroamento de um trabalho que vai fazer com que aquilo tenha um sentido verdadeiro $e$ aumente a referência das pessoas ... quer dizer, as pessoas vão ter um referencial pra se basear, saber por que preservar, que isso significa, vão contaminar também outras pessoas porque vão os alunos e as famílias também vão sendo conscientizadas disso, né? Então, isso é o que a gente precisa porque são poucas as áreas que foram preservadas, então se não houver um trabalho desse, elas ficam lá e não tem...”.

Diretora Municipal de fomento ao turismo.
} 


\subsubsection{A escolha do local da trilha}

Desde a primeira visita a São José do Rio Pardo já se buscava conhecer locais passíveis de implantação da trilha. Num primeiro momento, essas visitas eram feitas apenas pelo grupo de pesquisadoras, mas a partir o momento em que foi-se conhecendo interessados em participar do trabalho, estes foram inclusos no processo de escolha, sugerindo locais que consideravam apropriados, acompanhando as visitas de reconhecimento e avaliando as possibilidades de cada um desses locais.

$\mathrm{Na}$ área urbana, várias foram as possibilidades sugeridas e avaliadas. Uma delas seria uma trilha através da qual os usuários tivessem a oportunidade de percorrer os principais casarões e monumentos ligados à vida e obra de Euclides da Cunha (muitos dos quais já se configuram como atrativos turísticos da cidade), tais como a ponte sobre o rio Pardo, construída por ele; a casa onde viveu, quando esteve em São José do Rio Pardo e que hoje abriga um museu dedicado a ele; e o monumento construído no local de seu escritório, localizado às margens do rio Pardo.

Essa trilha abordaria principalmente as potencialidades e os problemas definidos anteriormente pelos participantes para a área urbana, tais como o rio Pardo, enquanto elemento preponderante da ocupação e dos costumes locais; a biodiversidade urbana, entendida num sentido mais amplo, incluindo aspectos sócio-culturais; e até mesmo a poluição do rio e a pouca arborização poderiam ser inclusos, já que poderiam ser facilmente percebidos pelos visitantes.

Um outro local, ainda na área urbana, que possibilitaria a implantação de uma trilha interpretativa do meio seria a Mata do Carneirinho (também conhecida como "Mata da Paixão") que consiste em um remanescente de vegetação nativa, pertencente ao município e localizado em uma área de bairros nobres da cidade.

A área desse remanescente é de aproximadamente $20.460 \mathrm{~m}^{2}$ e é cortada por uma nascente que desemboca no córrego Macaúbas (afluente do rio Pardo). Ali também eram despejadas águas pluviais trazidas por duas manilhas, provenientes de bairros circunvizinhos à mata (BOZZINI, 1996). Nos últimos anos essa canalização foi desviada para o sistema municipal de coleta de esgoto.

De acordo com o levantamento fitossociológico feito por Bozzini (op.cit.), a Mata do Carneirinho apresenta um pequeno índice de diversidade quando comparada a outras áreas, tais como a Mata da Capetinga, no Parque Estadual de Vassununga, em 
Santa Rita do Passa Quatro; a Mata da Figueira (mata galeria) em Mogi Guaçu; o Bosque dos Jequitibás, em Campinas; e a Mata São José, em Rio Claro.

O porte das árvores da mata foi definido pelo pesquisador como médio-alto, porém, ele observou efeitos resultantes da ação antrópica no interior desta. Embora em muitos locais haja um dossel denso, possibilitando maior retenção de umidade no solo e, conseqüentemente, grande quantidade de fungos e nutrientes, também foram detectadas áreas de clareiras, com grande quantidade de plantas pioneiras e de trepadeiras - o que evidencia que a área já sofria com o efeito de borda, ou seja, uma grande quantidade de lianas e cipós cresce sobre as árvores próximas à beirada da mata.

A Secretaria Municipal de Agricultura e Meio Ambiente, com a finalidade de aumentar a diversidade de espécies na Mata do Carneirinho, pretende replantar nessa área algumas espécies nativas da região já não são mais encontradas no local.

Esta área foi descartada para a implantação da trilha em virtude de seu pequeno grau de conservação e à sua grande ação antrópica. A Mata do Carneirinho necessitaria, ainda, de algumas melhorias de infra-estrutura, que possibilitariam as visitas de grupos, já que não existia uma picada aberta, e havia uma grande voçoroca beirando a nascente ali localizada. Além disso, pelo fato de uma das componentes do grupo de pesquisa já estar desenvolvendo, há alguns anos, seus trabalhos diretamente ligados ao rio Pardo, uma das participantes sugeriu que, como forma de manter a integração da presente pesquisa com as demais, desenvolvêssemos a trilha em um local no qual pudéssemos ter um contato visual com o rio, condição não atendida pela Mata do Carneirinho.

Embora a possibilidade de desenvolver uma trilha com o tema "biodiversidade urbana" fosse bastante interessante devido ao seu caráter inovador, também optamos por desenvolvê-la em uma área natural, em função de se manter a proposta inicial de integração das três pesquisas, pelo fato das outras participantes terem propostas de atividades em áreas naturais.

O primeiro local que conhecemos na área rural, a Fazenda Fortaleza, já despertou bastante atenção por ser um fragmento considerável de mata nativa, com árvores de grande porte e espécies representativas locais. Pareceu-nos o local ideal para o desenvolvimento do trabalho. Um dos participantes declarou que a Fazenda Fortaleza seria mesmo o local ideal para a construção da trilha, já que é uma das áreas mais bem preservadas do município.

Para que o pedido de autorização junto à Usina Itaiquara fosse formalizado, foinos pedido um ofício da Universidade, juntamente com uma breve explicação das 
finalidades da pesquisa e dos grupos envolvidos nas visitas (Apêndice C). No entanto, mesmo depois de encaminhar essa proposta, não obtivemos autorização dos administradores da fazenda para desenvolver o trabalho no local. Outras áreas foram então sugeridas pelos participantes de São José do Rio Pardo, e, embora não reunissem atrativos como fragmentos de matas nativas e outras formações vegetais, também poderiam ser utilizadas para a implantação da trilha.

Assim, um outro local visitado pelo grupo foi a Fazenda Santa Teresa. Esta é cortada pelo Rio do Peixe (afluente do Pardo) e, além deste, outros atrativos poderiam ser incorporados a uma possível trilha interpretativa: a Usina Rio do Peixe (uma hidrelétrica construída em 1920, localizada na propriedade), áreas de matas nativas, áreas de pastagens, ruínas de uma antiga fazenda de café, bem como a extração de areia no leito do rio. $\mathrm{O}$ interesse dos proprietários da fazenda em promover a visitação no local era grande, de forma que já estavam construindo uma infra-estrutura de apoio ao visitante: um restaurante, um barracão para reuniões e sanitários. Já existem, no local, trilhas que podem ser percorridas a pé, a cavalo ou de moto. Também já se pratica o rapel no local.

De fato, a Fazenda Santa Teresa possui um potencial enorme para o desenvolvimento de um turismo ambiental ou ainda de um turismo de aventura (Apêndice D). Porém, os locais com maiores possibilidades para uma trilha com finalidade educativa, passando por áreas de matas conservadas, estão localizados em morros e/ou áreas de difícil acesso, principalmente para se desenvolver atividades com grupos de crianças. As trilhas com finalidades educativas não devem exigir grandes esforços físicos dos visitantes, pois o cansaço é um dos fatores que pode comprometer a aprendizagem (BRINKER, 1994).

Outras três áreas passíveis de se implantar uma trilha interpretativa do meio, visitadas pelo grupo foram: a trilha dos carrapatos, a fazenda Tubaca e a área da cachoeira Santa Helena. Na primeira delas, apesar de já haver interesse prévio por parte de alguns integrantes do grupo em se implantar uma trilha no local, por ser este o trajeto do antigo trem que transportava o café produzido na região e pela paisagem privilegiada do rio Pardo, foi logo descartada pelo pouco potencial educativo, já que é praticamente constituída por áreas de pastagens e reflorestamento em morros, não apresentando nenhum trecho de mata preservada e nem mesmo uma trilha definida, além da possibilidade de infestação dos visitantes por carrapatos. 
“...[na trilha dos carrapatos] para chegar em alguns pontos a gente foi obrigado a dar algumas voltas e passa por lugares de difícil acesso, que pra criança não é aconselhável”.

Diretora Municipal de fomento ao turismo.

A área da cachoeira Santa Helena também foi descartada pelo pequeno grau de conservação da sua mata, representado por indivíduos de pequeno porte, presença de muitas clareiras e também pela grande quantidade de lixo encontrada às margens da cachoeira.

A Fazenda Tubaca possui uma área de 2.057 hectares, sendo 25\% desse total coberto por vegetação nativa, caracterizada como Floresta Estacional Semidecidual. A fazenda também possui áreas de pastagens, criação de gado confinado e áreas de cultivo de café. A área de mata utilizada para a atividade constitui-se num trecho remanescente de mata ciliar do rio Pardo, que se apresenta bastante conservado e tem uma grande diversidade de espécies. Esta área nos pareceu ideal por ser próxima à área urbana - o que facilitaria o transporte das crianças - com trechos planos, relativamente curtos, diminuindo as dificuldades da caminhada; ser de fácil acesso para ônibus escolares e, principalmente, por possuir uma grande quantidade de espécies botânicas já identificadas por meio de placas.

Por fim, logo na primeira reunião com os participantes, definimos, em conjunto, que a Fazenda Tubaca seria a área ideal para a implantação da trilha interpretativa do meio. Vários dos integrantes do grupo, inclusive alguns que estiveram conosco nas visitas de reconhecimento, apontaram a Fazenda Tubaca como sendo o local ideal para a implantação da trilha, em prejuízo dos outros locais visitados.

\footnotetext{
"Sem dúvida nenhuma foi falado ontem que o trecho da sua fazenda seria ..., se o [administrador da fazenda] tiver de acordo, seria o ideal porque ali já existe uma identificação de mata, já existe um trabalho, na verdade seria um novo trabalho que iria dar uma continuidade pra isso..."

Diretora de fomento ao turismo.
}

"Sem dúvida nenhuma a mata da Tubaca seria melhor mesmo, né.... ela tem acesso dos dois lados, já tem uma coisa identificada... Da ponte a entrada da mata tem 900m...”. Empresário de uma agência de esportes de aventura.

Até mesmo o administrador da Fazenda Tubaca acredita que o local seja o melhor para a implantação da trilha devido à presença de trechos de mata conservada.

"Eu acho que saindo da ponte ali da Nestlé [trilha dos carrapatos] tem coisa bonita, tirando isso, não vejo muito... não tem mata ali, né? Não tem mata nenhuma até chegar na Tubaca...”

Administrador da Fazenda Tubaca. 
Ele ainda deixou claro que possui uma grande preocupação com a questão da conservação das matas nativas em sua fazenda, quando mencionou que está tentando transformar uma dessas áreas em uma Reserva Particular do Patrimônio Nacional (RPPN).

\footnotetext{
“..Sou agricultor aqui de São José do Rio Pardo, resido na fazenda Tubaca ... e eu tô tentando, pleiteando uma RPPN que é uma reserva do patrimônio natural, dada a burocracia aqui no Brasil, está se arrastando já por ... 2 anos. Ainda não consegui, mas já está em Brasília, já foi aprovado por Ribeirão Preto e essa RPPN vai fazer uma área ali de mata, provavelmente vocês passaram próximo ou dentro, não sei qual foi o caminho da trilha ... passa a ser um patrimônio interessante pra cidade, para o turismo, seja lá o que for".

Administrador da Fazenda Tubaca.

"Essa área [a área da trilha] é a área da possível RPPN. Existe uma dificuldade tão grande, tão grande que faz com que o proprietário da área quase que não tem interesse nenhum em RPPN, interesse zero ... Então, independente da RPPN essa mata, eu gostaria que fosse incluída uma trilha para alguém aproveitar se não, não tem razão nenhuma. Já botei plaquinhas, quero botar mais ainda...”.

Administrador da Fazenda Tubaca.
}

Embora autorizando o uso da fazenda para a implantação da trilha e demonstrando preocupação com a conservação dos remanescentes de mata nativa da Tubaca, o administrador da fazenda mencionou algumas das suas inquietações em relação à implantação da trilha. Uma delas dizia respeito a quem seriam os usuários desta.

\footnotetext{
"Uma coisa importante é saber quem serão os usuários da trilha, com que veículos que eles vão na trilha porque a trilha de motocicleta, por exemplo, eu tenho pavor ... e quem vai a pé, a 200 por hora espantando tudo... Se for uma trilha a pé realmente é uma trilha interessante ... para observar a natureza, para conhecer a área... Ciclista até é admissível...”.

Administrador da Fazenda Tubaca.

“... essa seria uma trilha para andar a pé, no máximo de bicicleta ...”.

Administrador da Fazenda Tubaca.
}

Outra preocupação do administrador da fazenda Tubaca era em relação à infraestrutura que teríamos de construir para possibilitar a visitação no local.

\footnotetext{
"Eu estou querendo saber o que é preparar uma trilha, depois de pronta... o que que é? ... é botar banco para sentar, botar lixo pra jogar, o que é ?’.

Administrador da Fazenda Tubaca.
}

$\mathrm{Na}$ verdade, essa era uma dúvida de várias pessoas, já que desde os primeiros contatos com os participantes, utilizávamos a expressão “construir' ou "implantar uma 
trilha". Esse equívoco foi percebido após ter sido explicado que estávamos propondo elaborar um roteiro de interpretação do meio ambiente referente a um trajeto já existente por entre a mata e que nenhuma infra-estrutura seria construída no local.

A trilha da Tubaca constitui-se em um percurso linear, correspondente a um trecho de uma estrada previamente existente e que corta a fazenda - o que se constituiu em mais uma facilidade do local escolhido, já que não precisaríamos abrir uma picada no local. Nos casos em que para implantar de uma trilha educativa em Áreas de Preservação Permanente (APP) é necessário supressão da vegetação, deve-se obter uma autorização junto ao Departamento Estadual de Proteção aos Recursos Naturais (DEPRN).

Segundo o DEPRN, qualquer atividade que envolva a supressão de vegetação nativa depende de autorização, seja qual for o tipo da vegetação, em qualquer estágio de desenvolvimento. Além disso, qualquer intervenção em área de preservação permanente, sem autorização deste órgão, constitui crime ambiental, já que esta é protegida nos termos dos artigos $2^{\circ}$ e $3^{\circ}$ da Lei Federal $n^{\circ} 4.771 / 65$ (alterados pela Lei Federal $\left.n^{0} 7.803 / 89\right)^{7}$. Dessa forma, para a construção de trilhas em áreas de APPs, além da autorização do órgão competente, é necessário fazer um planejamento prévio e um monitoramento das atividades, buscando minimizar os impactos negativos decorrentes dessa atividade.

\subsubsection{Impactos da construção e do uso de trilhas em áreas naturais}

Os impactos negativos da recreação em áreas naturais podem parecer insignificantes se comparados àqueles causados por atividades agrícolas e industriais, testes nucleares, entre outros; porém eles não podem ser menosprezados (MAGRO, 1999). As trilhas provocam vários impactos ambientais, tanto físicos como visuais, sonoros e de cheiro. Embora constituam-se em um meio de canalizar esses impactos e de restringi-los a um determinado itinerário, seus efeitos podem se espalhar por até um metro a partir de cada lado da superfície da trilha propriamente dita (CATALDI, 1994).

A principal ação causadora de impacto em uma trilha é o pisoteamento do solo. O impacto mecânico do pisoteamento do solo resulta na diminuição dos seus poros e, conseqüentemente, na diminuição da sua capacidade de retenção de ar e absorção de

\footnotetext{
${ }^{7}$ Informações disponíveis no site: http://www.ambiente.sp.gov.br/deprn/deprn.htm
} 
água, alterando, assim, sua capacidade de sustentar a vida vegetal e animal (microfauna) associada. Embora a erosão dependa do tipo de solo, do padrão de drenagem da área e da declividade do terreno, a alteração e morte da vegetação (que impedem que as raízes auxiliem na manutenção da estrutura do solo) podem ser citadas como facilitadores desse processo (CATALDI, 1994).

Ainda segundo a mesma autora, a compactação do solo altera o padrão de circulação da água na região (diminuição da absorção e conseqüente aumento do escoamento superficial), aumentando, assim, a erosão.

O pisoteamento constante da superfície da trilha acaba destruindo a vegetação por choque mecânico direto. Dessa forma, ocorre a substituição de espécies mais sensíveis por outras mais resistentes ao pisoteio. A erosão expõe as raízes das plantas, dificultando sua sustentação e facilitando a contaminação destas por pragas. Quando uma trilha é aberta, também há alteração da luminosidade disponível, o que facilita o crescimento de plantas tolerantes à luz (MAGRO, 1999).

Embora o impacto das trilhas na fauna ainda não tenha sido sistematicamente estudado, acredita-se que deva haver um aumento no número de indivíduos de espécies tolerantes à presença humana e uma diminuição das mais sensíveis. Quando é detectado um grave distúrbio na fauna em decorrência do uso de trilhas, pode-se recorrer à alteração no traçado ou ao seu fechamento total, ou ambos apenas em períodos críticos, como épocas de reprodução. A multiplicação de trilhas pode ainda fragmentar a área necessária a algumas espécies animais, provocando interferência em suas rotas de deslocamento, destruição dos seus habitats e abrigos (CATALDI, op.cit.).

Além dos impactos acima citados, a autora ressalta que existem ainda aqueles decorrentes da contaminação de solos e rios - devido à disposição de lixo - além do desmatamento e agressões ao solo e a fauna, causados pelas queimadas.

Deve-se, portanto, fazer um manejo adequado dessas áreas visando a um mínimo impacto. Existem, na literatura, vários métodos, tais como: capacidade de carga, limites de mudanças aceitáveis (LAC), manejo do impacto de visitantes (do inglês VIM), objetivando auxiliar o manejo de áreas com finalidade recreativa (MAGRO, op.cit.).

As técnicas de mínimo impacto devem ser consideradas tanto na construção como no uso das trilhas. O planejamento de trilhas deve levar em consideração alguns fatores como: a variação das condições da região em decorrência das estações do ano, as informações técnicas (mapas, fotografias, etc.) já existentes sobre a região, a 
probabilidade de volume de uso futuro e as características de drenagem, solo, vegetação, habitat, topografia, uso e execução do projeto.

Durante a utilização da trilha deve-se avaliar ao longo do tempo, as alterações ocorridas nesta, tanto por impactos negativos decorrentes do uso, como por alterações naturais (estações do ano, etc.).

Alguns dos indicadores de impactos em trilhas propostos por Magro (1999) incluem o número de árvores danificadas, com inscrições e amarras; a presença ou ausência de serapilheira; a largura da trilha; a profundidade máxima da trilha; o número de trilhas não oficias; a presença de lixo, a presença de raízes expostas; a presença de infra-estrutura; e a invasão de gramíneas, espécies exóticas e cipós.

Dessa forma, alguns procedimentos adotados nas visitas às trilhas que visam ao mínimo impacto são: caminhar somente no leito da trilha; manter grupos pequenos; não arrancar galhos, nem escrever nas árvores; não molestar animais encontrados pelo caminho; não coletar espécimes da flora e da fauna, bem como atributos minerais; não fazer muito barulho, bem como não jogar lixo no local (CATALDI, 1994).

\subsubsection{Sugestões dos participantes ao roteiro interpretativo}

Após definido o local da trilha como sendo a área da fazenda Tubaca, os participantes locais fizeram diversas sugestões ao roteiro interpretativo. Dentre elas, destacam-se a extensão do trajeto a ser percorrido, levando-se em consideração o acesso de veículos dos visitantes no início e final do percurso.

\footnotetext{
"Nessa trilha dos Carrapatos a gente passa em frente ... o antigo leito do trem... mas ela é a maior, a menor seria essa da Tubaca. Porque ali eu acho que dá pra chegar o ônibus até a porteira, desce o pessoal, passa na mata e o ônibus vai pegar lá no Dezoito [clube], então, quer dizer, o pessoal só vai caminhar mesmo dentro da Tubaca. Saindo da ponte até a porteira da estrada do Dezoito, 2 km e 800 [metros]...".

Empresário de uma agência de esportes de aventura.
}

"Se for muito longa, pode ser reduzida e o ônibus chegar até a entrada da mata. O ônibus chega na saída da mata. Então, reduziria 900 m... é que ... a vista do rio nesse trecho é melhor porque dentro da mata a gente só vê o rio um pedacinho... ”.

Administrador da Fazenda Tubaca.

A idéia de se construir um roteiro interpretativo direcionado aos estudantes da $6^{\mathrm{a}}$ série do ensino fundamental partiu da própria escola e das pesquisadoras (pela experiência prévia com essa faixa etária), pelo fato do tema ambiental (apesar de ser um tema transversal) estar mais diretamente ligado ao currículo dessa série, o que facilitaria 
o trabalho dos professores, já que na maioria das vezes, estes não possuem formação mínima para trabalhar temas transversais em suas disciplinas.

Levando-se em consideração que, a princípio, os visitantes seriam estudantes de ensino fundamental, o grupo também discutiu a respeito da duração que a visita à trilha deveria ter e a quais séries ou turmas as atividades seriam direcionadas.

\begin{abstract}
"Eu tenho dúvida...quando a gente trabalha em escola, a primeira coisa que a duração não pode ultrapassar um período... A criança tem aula de manhã ou a tarde, então ... não pode ultrapassar um período...”.

Representante da Secretaria Municipal de Agricultura e Meio Ambiente.

“Eu acho que de pequeno... que tem que começar a aprender a preservação ... E eu acho que a gente tem que começar, realmente, como vocês falaram, desde o início, desde... eu diria até do infantil mesmo. Tá indo, vendo porque eu acho muito bacana trabalhar com os pequenininhos, sabe... e eles são interessados, eles aprendem mesmo, né?....”. Coordenadora pedagógica.

"A única coisa que tem é essa história de quinta a oitava (série). A gente fala de quinta a oitava, de primeira a quarta ... Quando você faz de quinta a oitava, você tem o inconveniente operacional da continuidade... no primeiro ano é uma beleza, dá certo. No segundo ano, o que vai acontecer: muitos já passaram por aquilo, então, é melhor você fixar uma série, ver o conteúdo e aí ele se torna perene naquela série, porque senão....causa desinteresse, ao passo que se você fixar uma serie, a qual verificar mais apropriada... vai ter sempre continuidade”.

Representante da Secretaria Municipal de Agricultura e Meio Ambiente.
\end{abstract}

Os participantes também fizeram referência à transversalidade do tema "meio ambiente" e à importância de se desenvolver um trabalho prévio em conjunto com as professoras dos alunos que visitariam o local, de forma que os temas desenvolvidos em sala de aula pudessem ser incorporados durante a visita à trilha, e também as discussões feitas durante a atividade na trilha pudessem ser ampliadas à sala de aula.

"Eu acho que dentro do possível... seria de encaixar o conteúdo da disciplina da escola
dentro da trilha, você pegar a disciplina de geografia, o que é que tem, como se fosse uma
aula prática, se você pegar o currículo da escola e dar uma olhada no livro da professora e
aí o que você pode encaixar daquilo como se fosse mesmo uma aula prática, dentro da
trilha ... esse conteúdo: Ciências, Geografia, história, um pouquinho de história...”.
Representante da Secretaria Municipal de Agricultura e Meio Ambiente.

"Fazer um link entre o que está sendo trabalhado na escola e a mata... Acho que esse é o caminho mesmo".

Diretora Municipal de fomento ao turismo.

Alguns temas também foram sugeridos pelos participantes para serem incorporados ao roteiro interpretativo da trilha da Tubaca. Um tema bastante 
interessante sugerido pelo administrador da fazenda foi a Revolução Constitucionalista de 1932, com vários episódios ocorridos ali mesmo na fazenda.

\footnotetext{
"Tem uma história curiosa, também... antes de chegar na ponte da Tubaca tem umas trincheiras da revolução de 32. E aquela ponte é a terceira ponte que ta lá porque a primeira ponte foi posto fogo na Revolução de 32 para os mineiros não atravessarem, então, contar um pouco da revolução de 32...".

Administrador da Fazenda Tubaca.
}

O grupo ressaltou a importância do resgate histórico como forma de compreensão e valorização da cultura local.

"O que a gente fazia com o turista... uma unanimidade é o seguinte: tem que contar história, se não tiver historia, a gente inventa, mas tem que ter... o turista gosta de história. Isso é fundamental... [Em São José do Rio Pardo] Não precisa nem inventar...”. Secretário Municipal de Turismo.

A questão da alteração climática, facilmente percebida entre um trecho de vegetação rasteira e uma área de mata, também foi lembrada como um aspecto interessante a ser abordado na visita à trilha da Tubaca.

\footnotetext{
"Variação de clima, talvez, alguma coisa de clima variação de temperatura, assim, dentro da mata, fora da mata...”.

Representante da Secretaria Municipal de Agricultura e Meio Ambiente.
}

A questão da fauna também foi considerada importante. Embora dificilmente possam ser vistas espécies de maior porte em uma mata, sua existência pode ser notada através de sons (especialmente aves) e vestígios, tais como pegadas e fezes. Também é possível observar uma grande variedade de insetos em uma mata.

\footnotetext{
"Você acha um objeto daqueles [dejetos de animais como capivara] como nós achamos, você vai ter certeza [de que existe fauna ali]..".

Diretora Municipal de fomento ao turismo.
}

Uma outra questão comentada foi em relação ao caráter educativo voltado principalmente à conservação, que deveria permear a atividade.

\footnotetext{
"Eu acho que essas visitas aí não sei como vai ser direcionadas com conhecimento, o pessoal tem que ir lá... não vai lá por curiosidade, tem que ser lá mais um soldado de proteção da natureza. Isso é importante”.

Diretor Municipal de infra-estrutura.
} 


\subsubsection{A elaboração do roteiro interpretativo}

A fase de elaboração do roteiro preliminar da trilha foi a menos participativa do processo. Após o local de implantação da trilha ter sido escolhido, com base nos elementos levantados durante o diagnóstico e nas sugestões feitas pelos participantes buscando sempre o enfoque da interpretação temática e da percepção ambiental -, foi elaborado um roteiro interpretativo prévio da trilha da Tubaca.

O roteiro elaborado corresponde a uma trilha interpretativa guiada, isto é, pressupõe a presença um monitor intérprete que, segundo Moraes (2000) é aquele que, além de conduzir o grupo pelo percurso estabelecido, estimula a sua participação nas atividades através das sensações, experiências e questionamentos a respeito do tema proposto. Esse tipo de trilha possui como vantagens a não necessidade de placas ou folhetos explicativos, a diminuição do risco de destruição ambiental, o esclarecimento de possíveis dúvidas e uma maior segurança para os visitantes, além de poder também ser adaptada a diferentes públicos. Alguns aspectos que são considerados como desvantagens em parques e outras áreas públicas (MORAES, op.cit.), neste caso (propriedade particular e estudantes de ensino fundamental), constituíam-se em vantagens, como por exemplo o fato das pessoas terem de seguir o ritmo do grupo e realizar as visitas em horários pré-determinados através de agendamento.

O roteiro elaborado compreende um percurso de $2900 \mathrm{~m}$, divididos em três trechos: os primeiros $1000 \mathrm{~m}$ correspondem a vegetação rasteira, os $1000 \mathrm{~m}$ seguintes correspondem a um trecho da mata ciliar do rio Pardo e os $900 \mathrm{~m}$ finais correspondem a mais um trecho de vegetação rasteira.

A interpretação temática caracteriza-se por se desenvolver de forma organizada ao redor de um tema principal e no máximo cinco sub-temas. Esse tipo de interpretação deve ter qualidade de um relato, ou seja, possuir um início, um meio, um fim e uma moral (HAM, 1992).

Assim, foram identificados um tema principal e quatro sub-temas (Quadro 7) a serem explorados na trilha da Tubaca. Depois de definidos esses temas, foram selecionados onze pontos interpretativos referentes apenas aos dois primeiros trechos do percurso da trilha (vegetação rasteira e fragmento de mata ciliar). A caminhada pelo último trecho (vegetação rasteira) se faz necessária, já que não há acesso a veículos como ônibus, imediatamente ao final do fragmento de mata ciliar. 
Quadro 7 - Tópico, tema e sub-temas da trilha da Tubaca.

\begin{tabular}{|l|}
\hline TÓPICO: Biodiversidade e Educação Ambiental em São José do Rio Pardo \\
\hline TEMA: A importância do rio Pardo na conservação da biodiversidade local e regional \\
\hline SUB-TEMA 1: A importância do rio Pardo na história e cultura local. \\
\hline SUB-TEMA 2: A importância da vegetação na conservação do rio e a importância do rio na \\
conservação da vegetação. \\
SUB-TEMA 3: A importância do solo na conservação da vegetação e a importância da vegetação \\
na conservação do solo. \\
\hline SUB-TEMA 4: A importância da fauna na conservação da vegetação e a importância da vegetação \\
na conservação da fauna.
\end{tabular}

Após definidos o tema e sub-temas a serem abordados no roteiro, foram selecionados os pontos interpretativos do trajeto por meio de mais uma visita ao fragmento de mata ciliar. Do ponto de vista da interpretação temática, é possível desenvolver várias excursões diferentes em uma mesma área, pois cada tema sugere diferentes paradas e narrações (HAM, 1992). Assim foi elaborado um roteiro prévio da trilha da Tubaca, que nesta primeira etapa, foi composto por 11 pontos interpretativos.

Segundo Ham (op.cit.), na elaboração de um roteiro de excursão, primeiro selecionam-se os pontos interpretativos, em função de um tema pré-definido; em seguida define-se a conclusão e, por último, a introdução. Ainda segundo o mesmo autor, geralmente uma excursão deve contemplar quatro partes.

A preparação, que acontece antes do início da caminhada, é a etapa na qual os guias se apresentam, dão as boas vindas e disponibilizam aos alunos algumas informações sobre a atividade, tais como: tempo de duração, esforço físico necessário, dificuldades, além de algumas recomendações de segurança e de mínimo impacto. Esta etapa foi planejada para acontecer ainda na escola.

A introdução da excursão, planejada para ser feita em um ponto interpretativo localizado na entrada da fazenda, tem como objetivo principal o de criar interesse pelo tema, fazendo com que as pessoas queiram participar da excursão. Essa estratégia era obtida ao mencionar o rio Pardo. Embora nesse ponto o contato com o rio ainda não fosse visual, essa citação tinha a finalidade de despertar a curiosidade (através do uso do mistério) sobre o tema. Nesse mesmo ponto ainda era feita uma breve explanação da atividade a ser desenvolvida e de como ela está organizada, informando também aos alunos a respeito das atividades da fazenda e curiosidades sobre o nome da mesma. As 
informações a respeito da segurança, equipamentos, materiais e condutas necessárias eram reforçadas.

O corpo da excursão consiste na narração feita em cada uma das paradas, que juntas desenvolvem o tema principal da atividade. Como já dito anteriormente, as paradas devem ser selecionadas em função do tema. Em cada parada a narração deve ter quatro passos:

Orientação: focar a atenção do grupo no objeto, cena ou idéia a ser enfatizada na parada.

Descrição: são explicados os detalhes da cena que deve ser observada. Para isso, é importante selecionar a informação de acordo com o tema.

Enlace temático: une a descrição ao tema. Revela a razão de fazer aquela parada.

Transição: finaliza a discussão daquele tópico e dá uma idéia do que será visto mais adiante - uso do mistério.

As trincheiras da Revolução Constitucionalista de 1932 constituíam o segundo ponto interpretativo. Nele a ênfase dada era a histórica, buscando mostrar aos alunos o local onde fatos históricos importantes, tanto no contexto local quanto nacional, aconteceram.

Por estarem relativamente distantes dos outros pontos selecionados, esses dois primeiros eram percorridos de ônibus. Somente a partir do terceiro ponto os visitantes iniciariam a caminhada.

No terceiro ponto interpretativo, localizado numa ponte que atravessa o rio Pardo, o enfoque, através de exemplos, era dado à importância do rio para todos os seres vivos, inclusive para a espécie humana. Também se fazia uma retrospectiva histórica do rio (da qualidade das suas águas, da quantidade de peixes, da pesca e da natação). Também conversamos a respeito de algumas maneiras de conservar o rio, já que outros itens relacionados seriam comentados mais adiante.

Ainda nesse mesmo ponto, passávamos por um bosque de ipês, localizado às margens do rio. Este bosque foi feito em homenagem ao pai do administrador da fazenda Tubaca, que faleceu enquanto fiscalizava as obras de reconstrução da ponte sobre o rio Pardo.

$\mathrm{O}$ quarto ponto interpretativo estava localizado à margem do rio Pardo, numa área desprovida de mata ciliar. Nele buscávamos, além de comentar os efeitos do crescimento das cidades, da agricultura e da pecuária na mata nativa, mostrar aos alunos 
a importância deste tipo de mata para a conservação do rio, através das evidências da falta dela.

Um pouco mais adiante (ponto 5) verificamos um trecho de regeneração de mata ciliar, podendo compará-lo com o trecho anterior (desprovido de mata) quanto a vários aspectos, tais como: presença de aves, microclima um pouco mais agradável, entre outros. Neste trajeto entre os pontos 5 e 6 era muito comum encontrarmos vestígios (pegadas e fezes) de grandes mamíferos, tais como capivara (Hydrochoeris hydrochoeris) e anta (Tapirus terrestris), possibilitando assim, que aproveitássemos esses elementos inesperados durante a atividade.

Na entrada da mata ciliar (ponto 6) pudemos discutir mais uma vez com os alunos a sua importância para a conservação do rio. Também pudemos chamar a atenção dos alunos para a diferença em relação ao microclima, os sons dos pássaros e o som do rio.

Um jequitibá-rosa (Cariniana legalis) centenário constituía o próximo ponto interpretativo (ponto7). Após a dinâmica, através da qual os visitantes formam um círculo em torno da árvore de forma a abraçá-la (adaptada de CORNELL, 1996) com o intuito de perceber seu diâmetro, a textura do seu tronco, a presença ou ausência de líquens e musgos, pudemos observar que esta árvore abriga diversas espécies, tais como: pássaros, insetos e epífitas. Assim, pudemos estabelecer relações de interdependência entre os vegetais e os animais.

O oitavo ponto interpretativo localizava-se próximo a uma figueira (Ficus guaranitica). Foi feita a dinâmica da trilha cega (adaptada de CORNELL, op.cit.) através da qual, de olhos vendados, os visitantes percorrem um trajeto demarcado com um barbante, por entre um trecho de mata. Este trajeto une árvores de espessuras e texturas diferentes, com presença ou ausência de líquens, musgos e raízes. A finalidade dessa dinâmica é explorar, através do tato, essa variedade de indivíduos presente na mata e até mesmo a presença da serapilheira através do som das folhas sendo pisadas. Ao final, todos tiram as vendas e tentam identificar o trajeto que percorreram.

Nesse ponto, era abordada a questão da importância da mata para a conservação do solo, ou seja, não só a parte aérea das árvores, como também as suas raízes protegem o solo da erosão e do assoreamento.

No ponto seguinte (ponto 9) pudemos estabelecer relações de interdependência entre a mata e o solo, visualizando uma árvore morta em processo de decomposição. Assim, comentamos a respeito da ciclagem de nutrientes na natureza. 
O penúltimo ponto interpretativo estava localizado em frente a um araticum cagão (Annona cacans). Além de chamar a atenção para a árvore e explicar o porquê do seu nome popular, atentávamos para a diversidade de espécies da mata, verificada pelos alunos através das placas de identificação, mostrando a importância da conservação não apenas daquelas identificadas, e sim de todas as árvores.

A conclusão, feita na última parada, busca reforçar o tema, de forma clara e precisa, mostrando pela última vez, a relação entre as paradas realizadas e a mensagem principal da excursão. Na trilha da Tubaca, esse ponto está localizado no final do trecho de mata, local onde realizávamos a dinâmica da teia de vida (adaptada de CORNELL, 1996), através da qual os visitantes formam um círculo e o primeiro diz algo que viu e gostou na trilha. Feito isso ele joga o barbante (segurando sua extremidade) para outra pessoa, que faz o mesmo, e assim sucessivamente, até que seja formada uma grande teia de barbante. Para demonstrar como cada elemento é importante, representa-se o dano em um deles através de um puxão no barbante. Outras pessoas também irão sentir o impacto desse puxão. Assim, conclui-se que na natureza todos os elementos estão interligados, ou seja, se um deles sofrer uma ação negativa, outros também serão prejudicados.

\subsubsection{Primeira revisão do roteiro interpretativo}

Durante o curso de formação de monitores ambientais, com o roteiro preliminar pronto, fizemos mais uma visita ao local da trilha para discutir como seria conduzida a atividade. Para orientar essa revisão no roteiro interpretativo foi utilizado como guia um roteiro de questões previamente elaborado (Apêndice E). Todos os participantes presentes atuaram ativamente nas dinâmicas propostas e sugeriram várias alterações no roteiro da trilha.

A primeira sugestão feita pelo grupo foi a de excluir os dois primeiros pontos interpretativos: aquele localizado na entrada da fazenda e o outro localizado nas trincheiras da Revolução Constitucionalista de 1932. De fato, esses eram pontos relativamente distantes do trecho principal (localizado entre o rio Pardo e a mata ciliar) e teriam de ser percorridos de ônibus. Os participantes sugeriram que a introdução ao tema da trilha fosse feita num local mais próximo ao rio Pardo, e as trincheiras poderiam compor um roteiro histórico mais específico. No caso dos estudantes de 
ensino fundamental, os aspectos históricos, que seriam abordados no ponto das trincheiras, poderiam estar contemplados em palestras anteriores às visitas.

O grupo também ponderou que a duração do percurso era um pouco extensa (cerca de $4 \mathrm{~h}$ ) e esse foi considerado mais um motivo para se eliminar os dois primeiros pontos.

Os participantes ainda declararam que havia muitas paradas próximas à entrada da mata ciliar e que uma delas também poderia ser eliminada. Optou-se por eliminar o ponto da mata ciliar em regeneração, já que os locais com e sem a presença de mata ciliar são bastante importantes por permitirem um contraste (visual, climático e auditivo) entre essas duas áreas.

Foi considerado que a trilha cumpre com os objetivos propostos e que nenhum outro objetivo deveria ser acrescentado para não comprometer o enfoque anteriormente definido.

Segundo os integrantes do grupo, o tema abordado na trilha está bastante claro para os visitantes, e esta desperta o interesse, já que é muito rica, havendo um contraste entre áreas com e sem mata. Além da mata ciliar, é possível observar diversas borboletas, vestígios de animais de maior porte, entre outros.

Também foi comentado que o trajeto poderia ser percorrido voltando pelo mesmo caminho. Isso estenderia o percurso em cerca de $1 \mathrm{~km}$, porém, poderia ser mais agradável em função do conforto térmico do trecho sombreado no interior mata.

O grupo também sugeriu que em várias etapas da trilha fosse feita uma dinâmica na qual os visitantes permanecessem em silêncio por alguns instantes para perceber os diferentes sons presentes na natureza, possibilitando, assim, uma comparação entre as diferentes áreas percorridas no trajeto.

As modificações feitas no roteiro prévio da trilha pelos participantes foram bastante pertinentes do ponto de vista prático, já que visavam a uma redução do tempo utilizado para o percurso, de forma que a atividade não se tornasse desestimulante e cansativa. Porém, em relação aos conteúdos e temas abordados, não houve grandes acréscimos durante esta etapa.

Assim, o roteiro elaborado buscou incorporar aspectos cognitivos (apresentação de informações) e oportunidades de aprendizado afetivo, na busca por um maior envolvimento individual e coletivo dos educandos no processo, através da interação perceptiva com o meio natural. 
Considerando que as sensações derivadas da interação dos órgãos dos sentidos com o meio (odores, sons, imagens, texturas e sabores) são uma via de integração entre este e o organismo, Seniciato e Cavassan (2003) defendem que metodologias educativas que exploram esses aspectos favorecem a aprendizagem, pois esta depende tanto do poder de raciocínio lógico quanto dos elementos subjetivos, como prazer, satisfação, crenças e motivações dos educandos.
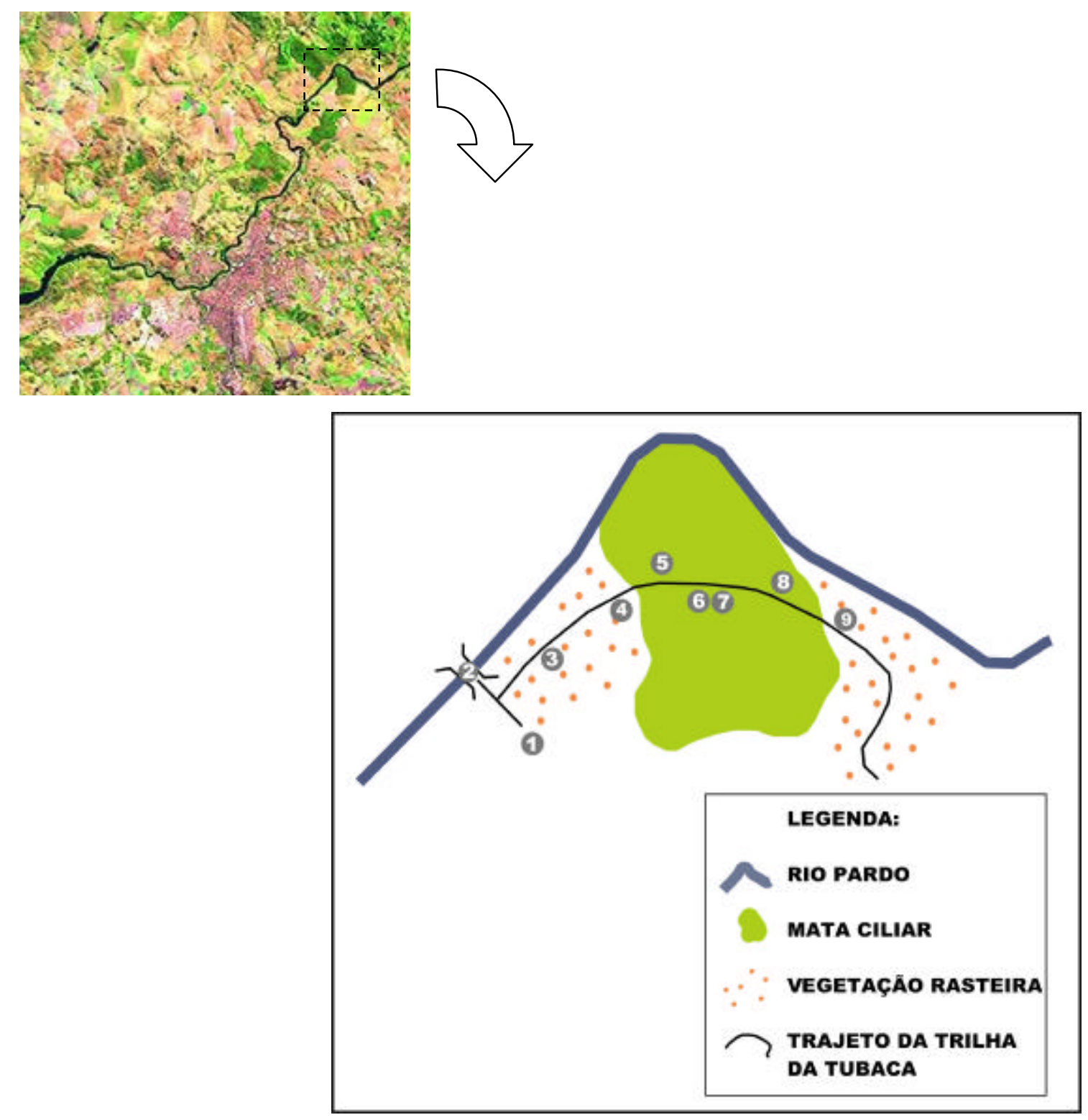

FIGURA 6 - Representação esquemática da trilha da Tubaca e seus pontos interpretativos.

Antes de serem aplicadas com os estudantes, as atividades de interação perceptiva com o meio e as dinâmicas de grupo também foram vivenciadas pelos participantes do processo, o que facilitou a sua aplicação posterior e permitiu verificar 
que o próprio grupo foi favorecido pela maior integração proporcionada por estas atividades.

O roteiro final da trilha interpretativa da Tubaca encontra-se no Apêndice F. A representação esquemática da trilha e sua localização em relação à área urbana municipal, podem ser vistas na Figura 6.

\subsection{Curso de formação de monitores ambientais}

O curso de formação de monitores ambientais surgiu do interesse e da necessidade - verificados logo nos primeiros contatos com os interessados em participar do projeto - de criar oportunidades para debater diversos temas ambientais e de conhecer algumas técnicas de percepção e interpretação ambiental, bem como aquelas de condução de grupos em trilhas interpretativas. Tal curso também consistiu em mais uma alternativa de fornecer subsídios para a continuidade do projeto, formando pessoas que pudessem atuar como monitores das visitas à trilha da Tubaca, elaborar novos roteiros interpretativos e conduzir grupos em atividades de educação ambiental por outras trilhas. Também foram apresentadas e discutidas com os participantes algumas dinâmicas de grupos e jogos interativos.

Esse curso não teve a intenção de fornecer um modelo pronto de elaboração de trilhas, mas sim, apresentar e debater alguns princípios de percepção e interpretação ambiental, que devem ser sempre adaptados aos diferentes contextos (locais, visitantes e finalidades). O curso apresentou uma maior ênfase às questões interpretativas da elaboração de uma trilha em detrimento das questões de manejo na construção desta, já que o roteiro interpretativo da Tubaca foi implantado numa trilha já existente. As questões referentes à condução de grupos também foram adaptadas ao presente contexto (finalidade educativa), concluindo-se que para trilhas com finalidade de aventura (com maiores percursos e graus de dificuldade), itens como equipamentos e segurança devem melhor analisados.

A duração do curso foi de 16 horas, distribuídas em dois dias de atividades (uma sexta-feira e um sábado), definidos pelos próprios participantes, em função da sua adequação aos compromissos pessoais e profissionais. Em princípio os participantes pensaram em incluir o curso como parte da programação do maior evento cultural local, 
a Semana Euclidiana ${ }^{8}$, tendo como público-alvo adolescentes que compõem a guardamirim municipal. Porém, optaram por fazer eles mesmos o curso, de forma que pudessem atuar posteriormente como multiplicadores do que foi discutido com outros grupos de possíveis monitores ambientais.

De fato, nesse primeiro momento seria mesmo mais interessante que as pessoas que já estavam envolvidas no processo da pesquisa participassem também do curso de formação de monitores ambientais. Isto porque, devido às suas formações, vivências e até mesmo aos cargos que ocupavam, elas possuíam maiores condições de compreender seus papéis como multiplicadores de idéias e práticas conservacionistas, e de difundir metodologias participativas e cooperativas, tanto na proposição de atividades educativas, quanto em projetos de gestão e gerenciamento ambiental em âmbito local.

O curso também consistiu em um momento de elaboração do roteiro da trilha da Tubaca, já que abrigou a primeira revisão deste pelos participantes.

\subsubsection{As expectativas dos participantes do curso}

Como forma de verificar quais as expectativas dos participantes do curso com relação a este, foi aplicada, logo no início das atividades, uma dinâmica através da qual cada pessoa exibiu um objeto que, de alguma forma, representasse as suas expectativas com relação ao curso.

A proposta do curso de formação de monitores ambientais estava bastante coerente com as expectativas dos participantes. Dentre as expectativas, destaca-se a aquisição de novos conhecimentos sobre meio ambiente, educação ambiental e condução de grupos em trilhas, além da troca de informações e experiências entre todos os participantes. Dessa forma e também através de um maior contato e integração com o meio natural, as expectativas passam pela sensibilização e conscientização pessoal como pré-requisito para a sensibilização e conscientização também de outros grupos.

A perspectiva de melhora da renda econômica, através da possibilidade de ampliação da atividade profissional também apareceu como uma expectativa por parte de alguns participantes. Seguem algumas citações que expressam essas expectativas:

\footnotetext{
${ }^{8}$ A Semana Euclidiana consiste em uma maratona de estudos a respeito da vida e obra de Euclides da Cunha que acontece na cidade todos os anos no mês de agosto.
} 
“..bom, eu espero do curso, assim, aprender várias coisas, tipo assim, educação ambiental, assim, espero que depois do curso eu possa mudar, assim, a visão, entendeu, em relação à natureza, cuidar mais. É isso".

Estudante.

“... meu objeto é aquele ventilador. Eu acho o ventilador ali tá representando primeiro, assim, a brisa, né, na natureza, aquele ar fresco, mas também pode significar o vento trazendo novos conhecimentos, clareando nossas idéias".

Empresário rural.

“... o meu é o galhinho aqui.. pensei numa integração com a natureza e aprender o que a natureza pode trazer de bom pra gente passar pro pessoal na trilha”.

Empresário de uma agência de esportes de aventura.

“... eu não consegui achar nenhum objeto, mas veio na minha mente agora essa luz aqui é meu objeto, vai clarear mais a cabeça da gente pra vir mais novas idéias”.

Estudante.

“... meu objeto é o caderninho aqui de anotações, que acho que é representar mais, assim, a troca de informações, né, e assim o conhecimento também que eu espero através da troca de informações entre o pessoal da equipe de aventura, pessoal de biologia, turismo, todos ligados à natureza, assim, através desse aprendizado, me conscientizar mais a respeito da natureza, ecologia”.

Estudante.

“... meu objeto é a página em branco e o lápis. Eu acho que é uma nova etapa que a gente tá abrindo com a página em branco totalmente disponível para ser escrita. Nós vamos começar uma nova história a partir de agora. Responsabilidade, hein?".

Diretora de fomento ao turismo.

\subsubsection{Avaliação do Curso}

A avaliação do curso de formação de monitores ambientais foi feita através da aplicação de questionários aos integrantes do grupo. Constituindo-se em questões apresentadas por escrito (GIL, 1990), a técnica teve por objetivo o conhecimento das opiniões, interesses e situações vivenciadas pelos participantes do curso. A maioria das questões presentes no questionário aplicado consistia em questões semi-abertas, ou seja, aquelas nas quais, embora seja apresentado um conjunto de alternativas para que as respostas sejam escolhidas, pede-se que elas sejam justificadas e ou explicadas. O modelo do questionário aplicado encontra-se no Apêndice G. Nenhum dos respondentes apresentou dúvidas em relação às perguntas.

Todos os nove participantes que responderam ao questionário declararam ter suas expectativas atingidas pelo curso. Comentou-se que o curso disponibilizou informações úteis e interessantes a respeito de meio ambiente, de educação ambiental, da condução de grupos de visitantes em áreas naturais, e da interação dos monitores com estes grupos. Com relação à trilha da Tubaca propriamente dita, o curso criou 
oportunidades para a discussão de seus objetivos, tópicos e dinâmicas, proporcionando novas experiências e possibilitando continuidade e aprofundamento nos temas tratados.

O quadro 8 resume a opinião dos participantes do curso quanto ao seu conteúdo, metodologias e duração.

Os cinco participantes que consideraram o conteúdo do curso como ótimo comentaram que este foi bastante abrangente, de grande interesse por parte do grupo, motivador e passível de ser aplicado no dia-a-dia e em outras trilhas.

Aqueles que responderam que o conteúdo abordado foi bom comentaram que o curso não possibilitou o aprofundamento em alguns temas, por ser muito rápido, e que com o desenvolvimento do trabalho e as vivências diárias surgirá necessidade de abordagem de outros temas não mencionados. Um dos participantes disse que o curso fortaleceu suas idéias prévias sobre biodiversidade, e outro pôde constatar o quanto o tema ambiental se faz presente no cotidiano das pessoas.

Quadro 8: Resumo da opinião dos participantes do curso quanto ao seu conteúdo, metodologias e duração.

\begin{tabular}{|c|c|c|c|l|}
\hline & Ótimo & Bom & Regular & Comentários \\
\hline Conteúdo & 5 & 4 & $\begin{array}{l}\text { Conteúdos importantes não abordados: aspectos } \\
\text { geográficos informações específicas sobre } \\
\text { espécies de árvores da trilha e aspectos legais da } \\
\text { utilização de reservas para abertura de trilhas. }\end{array}$ \\
\hline Metodologias & 7 & 2 & $\begin{array}{l}\text { Dinâmicas agradáveis, linguagem acessível e } \\
\text { abertura para que fossem expressas opiniões } \\
\text { diversas. }\end{array}$ \\
\hline Duração & 2 & 5 & 2 & $\begin{array}{l}\text { Quatro pessoas consideraram a duração do curso } \\
\text { suficiente, outras quatro alegaram que este } \\
\text { poderia ter sido mais longo para abranger outros } \\
\text { conteúdos. }\end{array}$ \\
\hline
\end{tabular}

Três dos participantes responderam que alguns assuntos considerados importantes não foram abordados durante o curso. Entre esses assuntos foram citados: aspectos geográficos (referentes ao local da trilha), informações específicas e curiosidades a respeito das espécies de árvores presentes no trajeto da trilha, além de alguns aspectos legais da utilização de reservas para abertura de trilhas. Cinco pessoas responderam que nenhum conteúdo importante deixou de ser abordado e uma pessoa deixou de responder a essa questão.

Em relação às metodologias utilizadas durante o curso, comentou-se que estas foram bastante dinâmicas e agradáveis, o conteúdo prático e teórico foi bem balanceado, a linguagem foi acessível e houve abertura para que fossem expressas opiniões diversas. 
No quesito "duração do curso", enquanto quatro participantes responderam que foi suficiente, bem distribuído, não sendo cansativo e nem monótono, outros quatro alegaram que este poderia ter sido mais longo para abranger outros assuntos.

Quadro 9: Contribuições do curso em nível pessoal

\begin{tabular}{|l|c|}
\hline Conhecimento de conceitos e técnicas & 4 \\
\hline Conscientização pessoal & 3 \\
\hline Maior entrosamento com o grupo & 2 \\
\hline Reflexão sobre temas ambientais & 1 \\
\hline Relaxamento/ satisfação & 1 \\
\hline
\end{tabular}

O quadro 9 resume as contribuições do curso em nível pessoal citadas pelos participantes. Dentre essas contribuições, foi mencionado: o conhecimento de conceitos relacionados ao meio ambiente, de técnicas para lidar com grupos; uma maior conscientização pessoal a respeito das questões ambientais e um maior entrosamento com os participantes do processo todo.

O quadro 10 resume as contribuições que o curso proporcionou aos participantes em nível profissional. Foram citadas: a apresentação de informações técnicas mais específicas e a aquisição de novas vivências e experiências, bem como a possibilidade de uma nova atuação profissional, por meio do desenvolvimento de um novo produto turístico numa agência local. Foi dito, ainda, que o curso constituiu-se em um estímulo para que seja difundido o que foi aprendido e um incentivo para que se possa aprofundar os estudos em temas que antes não despertariam interesse, tais como o tema "biodiversidade".

Quadro 10: Contribuições do curso em nível profissional.

\begin{tabular}{|l|c|}
\hline Conhecimento técnico específico & 5 \\
\hline Aquisição de vivência / experiência & 2 \\
\hline Possibilidade de nova atuação profissional & 2 \\
\hline Incentivo para passar adiante o que aprendeu & 1 \\
\hline Estímulo para aprofundar os estudos & 1 \\
\hline
\end{tabular}

Todos os nove participantes do curso responderam que este possibilitaria novas oportunidades. Estas estão resumidas no quadro 11. Seis deles citaram o aprimoramento 
da atividade profissional; outros seis mencionaram a possibilidade de multiplicar o que foi aprendido. A possibilidade de exercer uma nova atividade profissional foi citada por cinco participantes. Outras opções apontadas foram: aplicação das técnicas e dinâmicas na própria vivência e a possibilidade de abertura de trilhas educativas em uma outra propriedade particular.

Quadro 11: Novas oportunidades possibilitadas pelo curso de acordo com os participantes.

\begin{tabular}{|l|c|}
\hline Aprimoramento da atividade profissional & 6 \\
\hline Multiplicação do que foi aprendido & 6 \\
\hline Nova atividade profissional & 5 \\
\hline Outras & 2 \\
\hline
\end{tabular}

Ao serem questionados sobre o que mais gostaram no curso, quatro integrantes afirmaram que foi a possibilidade de conhecer e poder aplicar no seu dia-a-dia as dinâmicas de grupo vivenciadas. Dois deles responderam que foi da visita à trilha da Tubaca, outros dois alegaram que gostaram de tudo, e uma pessoa destacou, principalmente, a oportunidade proporcionada pelo curso.

Em relação aos que não gostaram, um dos integrantes citou o medo que sentiu ao atravessar a ponte sobre o rio Pardo. Outro indicou o fato de ter que acordar cedo em um sábado. Quatro dos participantes disseram que não houve nada de que não tivessem gostado, e três não responderam à questão.

Quanto às sugestões feitas pelos participantes do curso, dois deles recomendaram que o curso fosse realizado durante a semana; outros dois, que o curso fosse mais longo, para que houvesse mais tempo para mais atividades. Um dos integrantes sugeriu uma maior objetividade durante as discussões teóricas e dinâmicas; outro apontou não misturar aula teórica com a prática no mesmo dia, reservando, assim, um dia todo para percorrer a trilha. Uma pessoa disse não ter nenhuma sugestão a fazer e outra não respondeu à questão.

\subsection{Implementação da trilha}

Nesta etapa a trilha recebeu alguns grupos de visitantes: quatro turmas de alunos de $6^{\text {a }}$ série da escola municipal Stella Maris Barbosa Catalano, as quais foram divididas em três grupos. Apenas um deles foi avaliado sistematicamente. Os participantes 
envolveram-se ativamente dessa etapa, não só monitorando as visitas das crianças à trilha, como também fazendo diversas alterações no roteiro interpretativo a partir da experiência que estavam vivenciando.

$\mathrm{Na}$ visita do primeiro grupo, composto por 24 estudantes, optamos por percorrer a trilha até o final da área de mata e voltarmos pelo mesmo trajeto - o que acrescenta cerca de $1 \mathrm{~km}$ ao percurso original, de 2,8 km. Apesar de estarem bastante entusiasmadas, percebemos que as crianças ficaram um pouco cansadas ao final da atividade. Em razão desse cansaço e de um atraso de cerca de 30 minutos do ônibus que levou o grupo à fazenda, não foi possível fazer todas as paradas planejadas, em função do horário de retorno à escola.

Assim, na visita do segundo grupo, optamos por retomar o trajeto inicial (só de ida) da trilha. Nessa mesma visita, dividimos a turma em duas cada qual com 11 alunos. Cada uma delas foi acompanhada por uma professora e por dois monitores. De fato, essa divisão facilitou o trabalho nas paradas, proporcionou uma maior integração entre os alunos, além de interesse, motivação, atenção e participação direta na atividade. Porém, essa dinâmica exige a preparação de mais de um guia, o que ainda não era possível nessa etapa do trabalho.

Assim, essas duas visitas, embora não tendo sido avaliadas de forma sistemática, representaram uma etapa bastante importante na construção do roteiro da trilha, já que diversas alterações puderam ser feitas a partir da experiência direta com os visitantes. Os monitores (estudantes universitários e guias de atividades de esportes de aventura) também alegaram que essa etapa proporcionou uma melhor preparação pessoal para a condução da atividade.

A maioria dos componentes da turma que foi avaliada, efetivamente, ou seja, a que foi entrevistada antes e depois da atividade, demonstrou um interesse maior no trabalho, talvez pelo fato de ter participado de uma avaliação prévia em forma de discussão de grupo (grupo focal) e de ter tido uma palestra antes da visita à trilha. Porém, por ser a última semana de aula, algumas crianças pareciam encarar a atividade como um passeio e não como algo educativo. Inclusive, um pequeno grupo não quis participar das dinâmicas finais.

Em todas as visitas à trilha da Tubaca, as professoras que acompanhavam os grupos de estudantes não fizeram nenhuma intervenção referente aos conteúdos trabalhados, tampouco se manifestaram em relação ao comportamento deles. 
Tanto os participantes quanto as professoras que acompanharam o grupo apontaram como necessário o desenvolvimento de um trabalho com os professores, para que estes possam preparar os alunos para a visita, de forma que após a atividade, as discussões possam ser expandidas à sala de aula, nas diferentes disciplinas.

De fato, esse trabalho de formação dos professores para a atividade fazia parte da integração deste projeto com os demais projetos do grupo de pesquisa. Porém, essa integração efetivamente aconteceu até a etapa de elaboração do roteiro da trilha. Nas etapas seguintes (implantação e avaliação da atividade) as pesquisadoras acabaram desenvolvendo os trabalhos em escolas diferentes. Ainda assim, uma professora da escola municipal Stella Maris Barbora Catalano participou das atividades referentes à formação de professores. Porém, devido à época do ano em que este foi realizado, não houve tempo hábil para que ela pudesse desenvolver um trabalho com os outros professores da escola, nem com seus alunos.

Dessa forma, na prática, o único diferencial entre os estudantes que foram sistematicamente avaliados e os demais, é que os primeiros participaram de um grupo focal antes da atividade de visita à trilha e também assistiram a uma palestra preparada por pesquisadores envolvidos com a formação dos professores. Pelos moldes em que foi feita essa avaliação (grupo focal), ela também pode ser considerada uma preparação para a visita, na medida em que acaba despertando o interesse pelos temas a serem tratados.

\subsection{Avaliação da atividade de visita à trilha e do processo participativo}

\subsubsection{Avaliação da atividade de visita à trilha da Tubaca pelos estudantes}

Os grupos focais foram realizados com uma classe de 29 alunos da $6^{\mathrm{a}}$ série do período da manhã da escola municipal Stella Maris Barbosa Catalano. Essa turma foi dividida em três grupos (dois grupos de 10 e um grupo de 9 crianças) para a aplicação da técnica. Esta constituiu-se, além de um método de coleta de dados, em mais um momento de aprendizado, além da atividade da trilha propriamente dita, já que os alunos puderam debater suas idéias e opiniões, além de esclarecer possíveis dúvidas. Enfim, constituiu-se em um momento de reflexão a respeito da atividade.

A avaliação pós-trilha foi um pouco prejudicada pelo fato da atividade ter sido adiada, devido às chuvas, e devido ao curso de formação de professores que seria dado 
para implementar seus conhecimentos sobre a trilha Além disso, a visitação e a avaliação foram realizadas na última semana do ano letivo, em um dia no qual muitos alunos fariam provas de recuperação; por isso, nem todos os 29 alunos participaram da avaliação final da trilha.

As dificuldades de compreensão dos diálogos durante as transcrições, de análise dos dados de uma discussão de grupo, já comentadas no item referente ao diagnóstico participativo, também estiveram presentes nesse momento do trabalho. Os roteiros de perguntas dos grupos focais realizados antes e depois da visita à trilha da Tubaca encontram-se respectivamente nos Apêndices H e I.

Embora em princípio tenham surgido algumas dúvidas e discordâncias que geraram um certo debate a respeito do tema, os alunos demonstraram ter um conhecimento prévio do conceito de bacia hidrográfica. Nos três grupos de discussão surgiu a idéia de que existem possíveis interligações entre os rios, e em um dos grupos, um aluno definiu a bacia hidrográfica como sendo composta pelo rio principal e seus afluentes.

\footnotetext{
"Olha [indicando com o dedo sobre a carteira, o trajeto dos rios], tem o rio principal, aí tem seus afluentes e ele [o rio principal] deságua no mar”.

Lucas
}

Uma das turmas afirmou que se um rio for contaminado por agrotóxicos, os rios da região, de outros estados e até de outros países podem ser prejudicados, desde que façam parte da mesma bacia. Nos outros dois grupos essa questão também foi bastante discutida e, embora eles não tenham chegado a um consenso em relação aos outros estados, afirmaram que os rios de outros países não seriam prejudicados. Após a visita à trilha, todos concordaram que se o rio Pardo estiver poluído, podem ocorrer prejuízos para outros rios da bacia. A dúvida a respeito dos prejuízos aos rios de outros estados e países persistia; porém, para que a dúvida se dirimisse, retomamos o conceito de bacia hidrográfica e o trajeto do rio Pardo. Finalmente, os alunos concluíram que se o rio Pardo estiver poluído, poderá, sim, trazer prejuízos para os rios nos quais ele deságua.

Os alunos dos três grupos focais afirmaram que existe uma bacia hidrográfica na região de São José do Rio Pardo, porém apenas dois grupos a identificaram como a bacia do rio Pardo. No entanto, na avaliação pós-trilha, todos os alunos identificaram a bacia hidrográfica local como sendo a bacia do rio Pardo. Tanto antes como depois da visita à trilha, os alunos foram capazes de identificar diversos sistemas aquáticos da 
cidade, tais como: o rio Pardo, o rio do Peixe, o rio Fartura, a represa Euclides da Cunha, a represa Limoeiro e a represa Santa Alice.

Todos os alunos também disseram que peixes, algas, sapos, aves, vegetação ao lado do rio, ser humano, bois, hortas e solo poderiam ser prejudicados a partir da contaminação de um rio. Embora alguns desses itens tivessem gerado maiores dúvidas e discussões, tais como as algas (em um dos grupos foi dito que só existem em águas marinhas) e os sapos (que poderiam deslocar-se para locais menos poluídos), todos concordaram, enfim, que a água é essencial a todos os seres vivos.

A respeito do rio Pardo, embora alguns alunos afirmassem que este está bastante poluído, a maioria assegurou que a qualidade das suas águas é razoável, com alguns pontos mais ou menos poluídos.

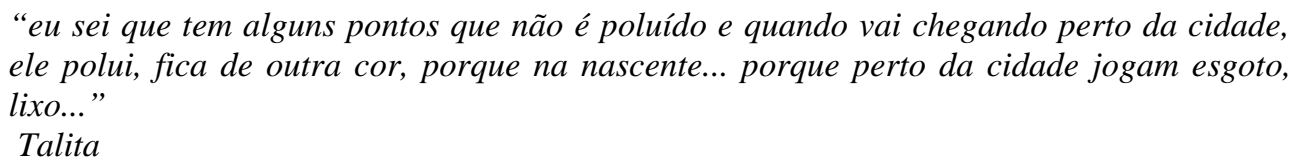
ele polui, fica de outra cor, porque na nascente... porque perto da cidade jogam esgoto, lixo..."

Talita

“Alguns pontos ele ta preservado, isso é bom, mas quando chega na cidade... ele tá mais ou menos. Porque quando chega perto da cidade, na beira do rio tem garrafa, plástico...". Angélica

“Tá misturando esgoto com o rio Pardo, então...”. Jéssica

Após a visita à trilha, permaneceu a idéia de que a qualidade das águas do rio Pardo é razoável, porém nota-se certa preocupação com essa qualidade no futuro.

\footnotetext{
"Teve um cara aí que me falou... veio dar uma palestra para a gente... ele falou assim... que não vai ter mais água no rio Pardo... daqui dez anos, né ?”.

Jailson
}

Em relação ao significado do rio para a cidade, embora todos esses itens tenham sido apontados, tanto antes quanto depois da visita à trilha, no primeiro momento foram ressaltados os aspectos utilitaristas do rio, tais como: fonte de água para consumo humano, higiene pessoal e até mesmo como fonte de lazer e atração turística local para a prática de esportes de aventura.

"É um ponto turístico porque muita gente vem de longe pra ver, para..." Rodrigo 
No segundo momento, foi enfatizada a proximidade do rio Pardo com a cidade e a sua importância refletida até no nome desta.

Todos os alunos afirmaram que houve uma diminuição do número de peixes no rio Pardo ao longo dos últimos anos devido, principalmente, à poluição. No entanto, ainda existem algumas espécies, como a piranha, que segundo eles, havia resistido à poluição, e tinha sido encontrada no rio pouco tempo antes da nossa reunião - notícia que foi veiculada nos principais meios de comunicação da cidade.

“... sabe onde é a ponte Euclides da Cunha? Ficava cheinho de gente lá pescando... agora passa lá não fica mais ninguém, não tem mais peixe, de vez em quanto tem alguém...”. Lucas

Em relação à conservação do rio Pardo, alguns alunos opinaram que nada poderia ser feito. A maioria, no entanto, contestou, acreditando que "não se pode perder a esperança", sugerindo medidas de conservação, tais como: tratar o esgoto, não jogar lixo em suas margens, e até mesmo a revitalização do rio.

"Eles deviam fazer uma lei que proibisse de jogar lixo no rio... se alguém visse as pessoas jogarem, denunciava e levava para a prisão”.

Lucas

Uma aluna considerou importante a oportunidade de participar da atividade da trilha interpretativa para poder transmitir aos outros alunos da escola, as informações e os conhecimentos adquiridos.

“Também é bom estar na escola, porque por nós sabermos disso as outras classes também ficariam sabendo”.

Talita

No que diz respeito à mata ciliar, conforme as citações a seguir, os alunos já tinham idéia de que se tratava da mata que acompanha o percurso do rio. Sabiam também uma das suas principais funções: a de evitar erosões das margens do rio e o conseqüentemente assoreamento deste. Apenas um dos grupos não soube informar a sua importância para o meio ambiente.

"É aquela mata que tem que passa do lado do rio".

Lucas 
“A mata ciliar é como se fosse nossos cílios... ele purifica o rio.... não deixa cair poeira dentro dos nossos olhos... ela é, assim como a mata ciliar do rio, ela segura... para não cair no rio"

Talita

Do total de alunos, quatro já tinham tido contato prévio com uma uma mata ciliar antes. Eles disseram que o clima dentro da mata é diferente do da cidade: mais úmido, fresco e agradável. Todos eles disseram ter gostado de conhecer a mata ciliar e gostariam de voltar ao local, se tivessem oportunidade. Aqueles que afirmaram nunca ter visitado uma mata ciliar também gostariam de conhecer.

Após a visita à trilha, todos os alunos responderam que se houvesse um desmatamento em uma área de mata ciliar, os seres vivos ali presentes morreriam, inclusive os animais, principalmente, por falta de abrigo e comida.

\footnotetext{
“Alguns... às vezes não iam encontrar o que comer e iam acabar morrendo...”. Guilherme

"Eles iam ficar sem abrigo... cada um queria alguma coisa... se você desmatar..." Talita
}

Quanto ao rio Pardo, este ficaria mais poluído e sofreria a ação do assoreamento, se a mata ciliar fosse retirada.

\footnotetext{
“Acho que... tipo, aqui tem a mata aqui assim.... aqui tá o rio, assim, ó.... [indicando com o dedo] Aí vamos supor que aqui é um barranco, se cai as árvores, cai a chuva o barranco faz assim ó.... [som de algo que está caindo]... as vezes tem sujeira lá, tudo... lixo lá...”. Lucas
}

Em relação à comparação entre uma mata ciliar e uma plantação de cana, todos os alunos alegaram que a primeira possui maior diversidade animal e vegetal do que a segunda. Afirmaram, no entanto, que diferentemente de uma monocultura, a mata ciliar possui diferentes espécies de vegetais. A partir daí, infere-se que a variedade de animais também será maior, já que eles se alimentam e buscam abrigo nas diferentes espécies vegetais. Um aluno comparou o clima de uma mata ciliar com o de uma plantação de cana e suas conseqüências para os animais.

"É um lugar que não vai ter o clima deles. Porque na cana-de-açúcar o clima... se tiver sol vai entrar lá dentro da cana de açúcar, então os animais podem ate morrer...”. Alessandro 
Após a visita a trilha, os alunos responderam que quando se substitui áreas de matas nativas por plantação de cana, a diversidade de plantas e animais diminui.

\footnotetext{
“Vão ter que achar outro lugar para morar [os animais]...”.

Lucas

"Algumas espécies de árvore, por exemplo, é muito difícil ter, se a gente cortar... os animais também porque se a gente não preservar... eles vão ficar sem... habitat”.

Talita
}

Tanto antes como depois da visita à trilha, os alunos foram enfáticos ao responder que não é adequado o cultivo da cana no lugar das matas nativas, mesmo considerando os usos que o ser humano faz da cana. Apesar disso, não souberam justificar suas respostas. Alguns disseram que deveriam ser mantidas algumas áreas nas quais as matas seriam preservadas.

\section{“Devia fazer uma área de preservação onde não pode cortar...”. Rodrigo.}

O lixo foi outro tema abordado na discussão. Quando questionados sobre quais as características de um local ideal para dispor o lixo municipal, os alunos responderam que deveria ser longe de rios, matas e da cidade.

\footnotetext{
"Eu colocaria num lugar assim meio deserto onde ninguém assim pudesse tocar, ninguém pudesse ir lá ou chegar assim perto do mato, porque pode chover e pode vir pro lado da gente ou pro lado da mata, então ...”.

Alessandro.
}

Para alguns estudantes, se o único local disponível para a disposição final do lixo fosse um terreno afastado da área urbana, porém próximo a uma nascente, seria melhor procurar um local em outra cidade. Outros citaram a reciclagem como solução para reduzir a quantidade de resíduo que vai para o aterro, porém nem todos os materiais podem ser reciclados. Um aluno disse que não faria um aterro, pois este prejudicaria o lençol freático. A partir daí, foi discutido um pouco a respeito de algumas diferenças entre aterro sanitário e lixão. Por fim, este aluno concluiu que o aterro sanitário seria a melhor solução para dispor os resíduos domiciliares de uma cidade.

"Poderia fazer um aterro sanitário, então, para não poluir os lençóis freáticos”. Jailson 
Todos os alunos já tinham ouvido falar da fazenda Tubaca, mas apenas quatro deles já tinham estado no local. Com exceção de um aluno, que afirmou não ter gostado da visita pelo fato de haver muitos mosquitos, todos os outros gostaram da experiência, e uma aluna resume o porquê:

\footnotetext{
“Eu já fui e eu gostei de lá, porque lá assim, na entrada, assim, tem ... árvore dos dois lados...fica um ar tão fresquinho, tão gostoso, ah, é muito bom...”.

Angélica
}

Ribeiro (2003) ressalta a importância das sensações experimentadas por estudantes em atividades que possibilitem o contato direto com o meio natural. Através das sensações expressas por alunos do ensino fundamental, em desenhos feitos 8 meses após a realização desse tipo de atividade, a autora chega à conclusão que estes observaram e aprenderam com os órgãos dos sentidos, como no caso das sensações oferecidas pela audição (som do rio, pássaros), olfato (cheiro da mata) e tato (temperatura fora e dentro da mata, diferentes troncos de árvores).

Quando questionados sobre como imaginavam aquele ambiente no passado, em um dos grupos houve uma discussão se havia mais ou menos árvores no local. Por fim, todos concordaram que tinha mais árvores. E a justificativa dada para o fato de haver menos árvores hoje foi a ação do fogo e do desmatamento, em função do crescimento urbano e das áreas de pastagens.

\footnotetext{
"Bem melhor... devia ter muito mais árvores, devia ser um lugar bem mais preservado... porque hoje muita gente desmata... quase ninguém dá valor...” Talita
}

Em relação ao futuro, os alunos responderam que a manutenção dessas áreas depende de iniciativas de conservação.

\footnotetext{
“Se a gente quiser... Vai lá e planta outra no lugar... porque se cai uma árvore, cai outra, cai outra e se ninguém se manifesta em plantar uma lá, vai caindo todas e ficar sem...” Lucas

“Se não cuidar aí já era”. Jailson
}

No que concerne às suas expectativas, os alunos disseram que encontrariam, na Tubaca, animais como pássaros, cobras, borboletas, tatu, tucano; muitas árvores diferentes, como figueira e ipê; além do rio Pardo. Eles disseram que gostariam de ver 
rios, flores, animais, macaco e cachoeira, e não gostariam de ver poluição, árvores cortadas, lixo jogado no chão, cobra, cigarro, bicho barbeiro, pernilongo, mosca, escorpião, poluição, sujeira, desmatamento, seca, fogo, dengue, sujeira, animais mortos, mau cheiro e animais maltratados. Apesar de não terem visto muitos dos itens mencionados durante a avaliação anterior à visita, os estudantes não manifestaram sentimentos de frustração ou tristeza após a visita.

Segundo os mesmos, o que os alunos mais gostaram na visita à trilha foi a possibilidade de conhecer diferentes árvores e seus nomes, especialmente o jequitibá e a figueira (que são os exemplares que mais chamam a atenção por causa de seu porte); saber que muitos animais vivem naquela área por meio das suas pegadas; e das brincadeiras, especialmente aquelas nas quais os alunos têm seus olhos vendados. Duas crianças disseram ter gostado de todas as atividades.

“O que a gente mais gostou? Uma coisa só? Uma só? Uma?... Gostei de tudo!”. Jailson

O que os alunos menos gostaram foi do cheiro de silo (local onde é armazenado o capim para alimentar o gado no período de estiagem), num trecho no início da trilha. Duas meninas alegaram não ter gostado de atravessarem uma área com lama,e a ponte sobre o rio Pardo, em razão do medo. Essa ponte consiste em uma estrutura de ferro com o piso de madeira, e apresenta certo movimento quando há passagem de pessoas e veículos.

As sugestões dadas pelos alunos para melhorar a atividade foram: fazer cavalgada para não tornar a atividade muito cansativa e reforçar a ponte que atravessa o rio Pardo.

Ribeiro (2003) também nos lembra que mesmo as sensações desagradáveis como o cheiro do silo e o medo de atravessar a ponte também podem marcar a experiência de uma forma negativa, podendo fazer com que o aluno não mais queira voltar à trilha. Porém, todos os alunos responderam que fariam a trilha novamente e levariam consigo os amigos, familiares, colegas do bairro, enfim, as pessoas de quem eles gostam. A maioria dos alunos atribuiu nota dez à trilha da Tubaca. Dois alunos atribuíram nota nove e meio em razão do trecho com lama, e um aluno atribuiu nota nove por causa do cheiro desagradável de silo no início do percurso.

No que tange ao percurso da trilha propriamente dito, os alunos disseram que sua extensão estava adequada. Apenas um aluno sentiu-se cansado após a atividade e dois deles disseram que a trilha poderia ser mais estreita. Um outro afirmou que o trecho de 
mata também poderia ser mais extenso. O número de paradas também foi considerado adequado pela maioria (apenas um aluno sugeriu que fossem feitas menos paradas).

Todos elogiaram a atuação dos monitores, enfatizando que foram muito simpáticos, divertidos e que responderam a todas as suas dúvidas. Os adjetivos utilizados pelos alunos para descrever o que acharam da trilha foram: excelente, ótima, boa, legal, cem por cento, e preservada.

Os alunos disseram que aprenderam diversas curiosidades sobre as árvores, especialmente as que mais chamam a atenção, como a figueira, o jequitibá; e sobre os animais, identificados pelos seus vestígios. Eles também puderam aprender alguns conceitos ecológicos através de brincadeiras e tiveram a oportunidade de contar essa experiência para seus pais, que, segundo eles, aprovaram a iniciativa.

Quando questionados sobre como resumiriam o que aprenderam na trilha, estes citaram diversos aspectos de conservação da mata e do rio Pardo. Porém, o que fícou mais nítido foram os aspectos da convivência em grupo e da interação com outras pessoas.

“...eu aprendi que é bom andar em grupo no meio da mata.... que a gente pode aprender um com o outro, não é verdade?... a gente aprende não poluir, o que a gente pode fazer para melhorar o meio ambiente, não é verdade?... a gente aprendeu também a não destruir a mata ciliar, a não poluir os rios... porque se a gente poluir... e se não tiver mais rio ?’”. Lucas

"Eu aprendi que andar no meio da mata cansa... eu aprendi a conservar a mata... eu aprendi que para andar em grupo tem que respeitar quem ta comandando se não pode se perder....eu aprendi a conservar a mata ciliar, eu aprendi mais sobre as árvores...". Guilherme

“... eu aprendi a usar a mata com inteligência, eu aprendi algumas coisas sobre meio ambiente, sobre espécies de árvores. Eu aprendi sobre não jogar lixo, ... eu aprendi tudo sobre a mata, quase tudo... quase tudo sobre a natureza”. Jailson

"Eu aprendi a conservar o meio ambiente, a cuidar do rio, ao mesmo tempo que agente estava brincando, a gente aprendeu bastante coisa...”

Alessandro

Por fim, os alunos disseram que recebem informações a respeito do meio ambiente de São José do Rio Pardo através de jornal, rádio, televisão, revistas, internet, na escola, na rua, e com outras pessoas: pais, amigos e parentes.

Ainda que os estudantes avaliados já tivessem um conhecimento prévio considerável a respeito da maioria dos assuntos tratados na visita à trilha da Tubaca, nota-se acréscimos nesse aspecto, especialmente quanto à conservação dos elementos naturais do meio, que anteriormente eram encarados apenas como recursos à disposição 
dos seres humanos. Percebe-se também uma maior preocupação com a dimensão temporal dessa conservação, ou seja, a preocupação com o futuro e a necessidade iminente de conservação. Os estudantes ressaltaram a importância da experiência vivida em contato direto com o meio natural, proporcionada pela atividade e principalmente pela interação com os colegas e os monitores. Esse é um resultado muito importante, já que as relações das pessoas em grupos, o diálogo e o respeito ao diverso são alguns valores muito importantes a serem resgatados em processos de educação ambiental.

Embora a avaliação de pesquisas relacionadas a valores consista em uma tarefa complicada, já que o tempo necessário para que modificações perceptíveis ou refletidas em atitudes se estabeleçam, podendo ser observadas e avaliadas, muitas vezes não é compatível com os prazos estabelecidos por instituições de pesquisa e agências financiadoras, para as investigações científicas, Wilson (1997) considera a afetividade como grande motivadora de mudanças de valores e atitudes, já que as lembranças prazerosas aumentam a probabilidade de retenção de informações, tornando-as parte da memória de médio ou longo prazo, e propiciando uma ampliação no quadro pessoal de referências sobre determinado tema ou situação.

A mesma autora avalia ainda que o trabalho com atividades que proporcionem uma interação perceptiva com o meio e com outras pessoas, além de facilitar a compreensão e incorporação de informações, através da memorização das experiências (cognitivas e afetivas) e associações, também proporciona um maior envolvimento dos educandos com o processo. $\mathrm{O}$ fato de aliar o processo cognitivo ao afetivo torna o processo mais prazeroso, tanto para educandos como para educador. Acredita-se, portanto, que a influência na formação dos valores dos educandos seja a maior contribuição desse tipo de atividade.

Sabe-se, porém, que essas atividades de curta duração e/ou eventuais no processo educacional têm poucas possibilidades de propiciar a construção de objetivos de natureza tão variada e complexa como aqueles que caracterizam, segundo a literatura, o processo de educação ambiental. Assim, atividades de visitas às trilhas deveriam ser consideradas como parte de um processo mais amplo de educação ambiental, na medida em que suas contribuições deveriam ser exploradas ao máximo. No caso deste trabalho seria fundamental proporcionar uma formação aos professores desses estudantes, para que eles pudessem desenvolver outras atividades em momentos anteriores e posteriores à visita à trilha, dentro e fora da sala de aula, de forma a permitir que essa atividade não se caracterize como um evento isolado no processo educacional dos alunos. 


\subsubsection{Avaliação da atividade de visita à trilha da Tubaca pelos participantes} do processo

O roteiro de questões utilizado para o grupo focal realizado com a finalidade de avaliar as visitas dos estudantes à trilha da Tubaca, segundo os participantes do processo de construção desta, encontra-se no Apêndice J.

Devido às mudanças no cenário político municipal, dois participantes que ocupavam cargos públicos (o Secretário Municipal de Turismo e a Diretora Municipal de Fomento ao Turismo) não compareceram a esta reunião, o que representou uma grande perda na avaliação do processo conduzido. A atual Secretária Municipal de Turismo compareceu e explicitou claramente a sua intenção em apoiar a continuidade da atividade.

Todos os participantes presentes gostaram muito do projeto. Eles ressaltaram que o local escolhido é ideal para esse tipo de atividade, entre outras coisas, devido à sua proximidade com a área urbana municipal, o que facilita o acesso de visitantes.

"Foi ótimo... O levantamento da trilha, o lugar foi o melhor que a gente achou, perto da cidade com uma mata privilegiada... já é uma trilha que já tem algumas árvores identificadas, então quer dizer, já fica mais fácil da gente dizer qual é a árvore 'essa é a figueira'. Então eu acho que casou: acho que foi um lugar perfeito, não tem o que falar..." Empresário de uma agência de esportes de aventura.

O fato de ter sido feito um levantamento prévio da vegetação local, e por esse motivo algumas das árvores já estarem identificadas através de placas com seus nomes populares e científicos, constituiu-se em uma grande facilidade para os participantes que atuaram como monitores na visita à trilha. Outras facilidades citadas por eles no desempenho da atividade foram: a extensão da trilha e o sombreamento na maior parte do percurso.

"É uma trilha onde vai ter um aprendizado ecológico, de preservação. Até o tamanho dela é excelente. É uma trilha que não cansa. Você não vai andar ali pra fazer caminhada, você vai lá pra conhecer..."

Diretor Municipal de infra-estrutura.

No que se refere às dificuldades encontradas durante a atividade, dois participantes mencionaram o transporte dos alunos da escola para a fazenda. O veículo que fazia esse transporte era cedido pela prefeitura municipal, e sua reserva era normalmente feita pela coordenadora ou diretora da escola participante. De qualquer 
forma, a diretora da escola afirmou que não teve nenhuma dificuldade em relação a esse aspecto.

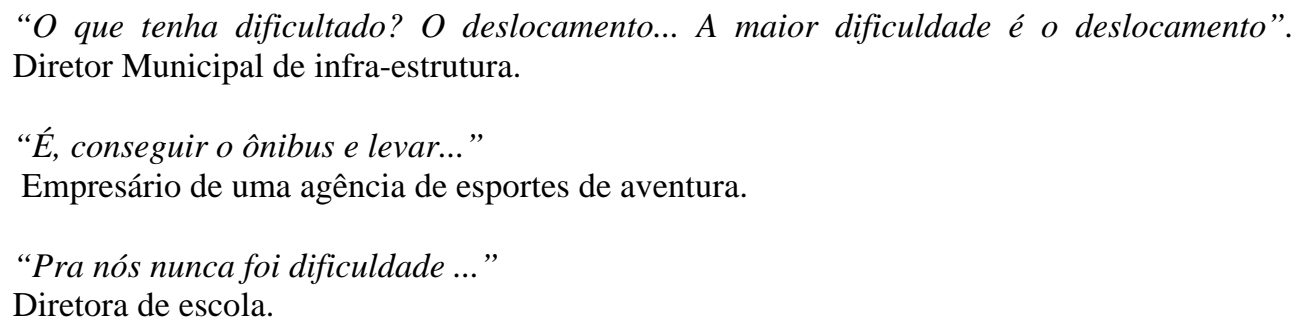

Justamente para evitar essa suposta dificuldade, a atual Secretária Municipal de Turismo propôs que nas próximas etapas do projeto, a reserva do veículo para o transporte dos estudantes fosse feita através da própria Secretaria Municipal de Turismo. Essa postura da Secretária Municipal de Turismo pode ser um indicativo do seu engajamento pessoal na continuidade do projeto, já que, embora não tenha participado das etapas anteriores do processo, mostrou-se bastante receptiva ao projeto, se propondo a auxiliar na resolução de pequenas dificuldades encontradas pelo grupo.

\footnotetext{
"Pra gente seria interessante, pra gente enquanto Prefeitura Municipal, Secretaria de Turismo, ta fazendo o agendamento e depois tá passando pro pessoal da [agência de esportes e aventura], justamente por causa do transporte. Com as escolas estaduais, mesmo particulares é a prefeitura que cede o transporte... Seria interessante que as escolas interessadas em estar desenvolvendo projeto, selecionasse a turma... entraria em contato com a Secretaria, estaria agendando, aí a gente faz o requerimento para o setor de transporte, conseguindo autorização entraria em contato com o pessoal da [agência de esportes e aventura]... passando pra eles... confirmando a participação deles... e aí vocês teriam um tempo para tá organizando, tá sensibilizando”.

Secretária Municipal de Turismo.
}

Outra dificuldade encontrada, principalmente pelos participantes que atuaram como monitores da trilha, foi a conduta eufórica e dispersiva dos alunos durante a atividade. Embora durante as visitas à trilha, as professoras acompanhantes tenham alegado que essa é uma situação comum em sala de aula, ela se constituiu em uma dificuldade para os monitores pelo fato da maioria deles não possuir experiência prévia em desenvolver atividades com crianças.

\footnotetext{
“...Eu achei que eles estavam um pouco dispersos. A hora que eles entram na mata, eles ficam olhando e um mexe com o outro, joga semente no outro... A gente tem que chamar $e$ tentar... mas eles prestam atenção. Na hora que eles têm alguma dúvida, a gente esclarece, $e$ aí todo mundo junto quer saber... Eu achei que o maior problema e só um pouco a dispersão. Do resto correu tudo bem..."

Empresário de uma agência de esportes de aventura.
} 
Um dos participantes aplicou uma das dinâmicas feitas durante a visita à trilha da Tubaca com alguns estudantes em sala de aula e percebeu uma dificuldade ainda maior.

\begin{abstract}
“(...) fiz a brincadeira da anta dentro da classe. $70 \%$ aderiram, adoraram, brincaram, acharam o máximo... quinta série, você fazer dentro duma classe é totalmente diferente... do ambiente lá, né ? Por mais que eles fiquem dispersos, dentro da classe então, você propor um negocio novo pra eles, tem gente que não tá nem aí, fica fazendo bagunça o dia inteiro dentro da classe e ... tinha gente tentando empurrar um ao outro, bom, mas dentro da classe é mais difícil ainda de você trabalhar do que no campo... Eu presenciei”. Biólogo e agricultor.
\end{abstract}

Todos os participantes do processo de elaboração da trilha concordam que a presença de monitores que conduzam os alunos pelo trajeto é fundamental neste tipo de atividade. Uma professora (que ainda não havia participado das atividades) ponderou a respeito dessa importância através de uma experiência de saída com os estudantes sem o auxílio de monitores.

\begin{abstract}
"Eu senti dificuldade quando eu saí sozinha com os meus alunos. Dá um peso, por isso que quando eu vejo um grupo maior que a gente pode tá junto, ele com rádio, ele com isso, com aquilo... nossa, dá pra fazer mais vezes... porque quando a gente vai só 1, 2 professores, 30 crianças agitadas... Eu sinto assim o meu coração pulsar o tempo todo... lógico que a gente vai confiando... mas mesmo assim... os alunos estão muito assim cheios de energia e às vezes eles querem fazer as próprias regras, então é legal ter um grupo mais inteiro acompanhando a gente, isoladamente eu não quero mais me arriscar não...”.

Professora.
\end{abstract}

Os participantes também acreditam que a atividade realizada com o grupo de alunos que foi sistematicamente avaliado tenha sido mais proveitosa, e atribuem dois motivos a esse fato: a preparação prévia desses alunos para a atividade através de uma palestra e uma discussão de grupo (grupo focal), e porque após a realização da atividade com dois grupos de alunos, os monitores já se sentiam mais familiarizados com o roteiro da trilha e com a conduta das crianças.

"Eu acredito que a última turma, que teve a palestra, tudo, eles estavam bem mais enfocados, bem mais preparados no assunto. As primeiras turmas foram mais bagunça, mais dispersão..."

Agricultor.

"Na primeira nem a gente tava... foi uma experiência nova até pra gente. Acho que a primeira, a gente não pode ter muita base. Foi mais pra gente aprender a trabalhar com... no nosso caso aqui, a gente não estava acostumado a trabalhar com criança A gente trabalha com esporte e aventura é um pessoal já mais velho. Então é diferente”. Empresário de uma agência de esportes de aventura. 
Dessa forma, a partir das falas dos participantes, fica clara a importância dos estudantes serem previamente preparados para a visita à trilha, seja por meio de palestras, dinâmicas, entre outros.

\begin{abstract}
"Eu acho importante essa palestra com as crianças não precisa nem ser uma palestra, o próprio professor ou alguém da [agência de esportes de aventura]... alguém que vá lá conversar com eles sobre o passeio, sobre a trilha pra estar sensibilizando ... a gente faz uma sensibilização com as crianças porque aí eles já vão com um objetivo para a trilha.". Secretária Municipal de Turismo.

"Mas é importante estar sensibilizando os alunos antes, justamente para que eles aproveitem bem esse passeio... Tem que ter um objetivo educacional implícito pra que realmente a avaliação seja bastante positiva. A experiência é muito importante, mas é uma oportunidade de enriquecer o conteúdo enfocado".

Secretária Municipal de Turismo.
\end{abstract}

Uma das sugestões feitas pelos participantes para a continuidade da atividade foi a adaptação do roteiro da trilha para visitas com grupos de crianças de faixas etárias menores. De fato, essa é uma possibilidade bastante interessante e que já havia sido pensada em nossa primeira reunião. Porém, acreditamos que tal adequação seja uma proposta para etapas futuras, já que demanda, ente outros fatores, um maior número de monitores para acompanhá-las.

\footnotetext{
"Os menores até poderiam estar participando mas aí uma turma menor..."

Diretora de escola.

"Eu acredito que a trilha nem é cansativa. O problema é só realmente tomar conta desse pessoal menor”.

Empresário de uma agência de esportes de aventura.

"A trilha poderia ser um pouquinho mais curta e a quantidade de alunos também. Aí acho que seria legal”.

Diretora de escola.
}

Outra sugestão feita pelos participantes foi a de se desenvolver um trabalho com os professores antes da atividade com os alunos, para que estes pudessem abordar em sala de aula, antes e depois da atividade, os temas tratados na visita à trilha.

\footnotetext{
"Mas um passeio deste tem que ser planejado, envolvendo as várias disciplinas; tem o pessoal de geografia, tem o pessoal de história, de ciências, que pode estar envolvendo, levantando algumas questões para eles estarem observando. É muito rico e além de tudo lá é muito bonito. Então, professor de artes, quem quiser fotografar pra depois estar fazendo um trabalho, uma exposição, fazer alguma pintura da foto, uma escultura, modelagem, quer dizer: são muitas as atividades que as crianças podem estar fazendo a partir de um passeio desses; um levantamento dos tipos de árvores, quais são as espécies, os animais, as folhagens, quer dizer é muito rico; um passeio deste marca pra vida toda. A escola pode a
} 
partir de uma trilha desta, trabalhar quase com tudo, inclusive tem conteúdo para todas as disciplinas, né?".

Secretária Municipal de Turismo.

“Às vezes o que afasta os professores de estar fazendo esse tipo de atividade é que eles não estão motivados ainda. Sabe aquela coisa que fica preso naquela coisa antiga, fica meio restrito a manter o que é... então essa motivação falta, essa coisa deles irem pra experimentar...".

Professora.

“...para sensibilizar o professor e por que não desenvolver uma trilha só de professores? Fazer um trabalho com os professores primeiro. Porque eu acho que eu não consigo sensibilizar meu aluno se eu não estiver sensibilizado. A gente vê a resistência dos professores, quanto à mudança, a sair, porque é trabalhoso... o professor tem responsabilidade... não é todo professor que assume isso, muitos resistem à mudança, então eu acho que seria interessante... programar um dia, uma escola, vai um grupo de professor, acho que seria um trabalho interessante pra tá sensibilizando depois o aluno". Coordenadora pedagógica.

Nessa última fala, pudemos detectar uma falta de comunicação entre os professores e a coordenação da escola participante do projeto, já que foi realizado um trabalho de formação dos professores por um outro membro do grupo de pesquisa, com a participação de uma professora da rede municipal de ensino.

Uma outra professora também sugeriu que fossem desenvolvidos outros trabalhos em conjunto a partir da trilha.

\footnotetext{
"Ou quando repetir a trilha, levar uma coisa nova para fazer, ou ver um filme, ver uma música, ou fazer um texto, ou plantar, fazer algum plantio...'nós vamos cuidar dessa árvore?', 'nós vamos vim ver aqui se ela ta indo direitinho?', 'nós vamos por a plaquinha aqui?'. Então que é um compromisso com alguma coisa aquela área”.

Professora.
}

Por fim, todos os participantes do processo e ainda as pessoas que desejam participar das próximas etapas do projeto, o consideram bastante importante no sentido de se criar oportunidades de aprendizado, sensibilização e conscientização de alunos e professores a respeito de temas ambientais.

\footnotetext{
"O que eu percebo nesses tipos de projetos e programas fora da sala de aula é nunca mais esquece essa oportunidade de ter saído, essa vivência, essa coisa que concretizou, que sentiu, que fez acontecer, não esquece nunca mais, qualquer coisa que se constrói, seja na massinha modelar, seja em fotografar, no anotar, em pesquisar... é um registro pra sempre. Então é importante fazer essas coisas. Cansa ? Cansa. É uma responsabilidade? É uma responsabilidade e a gente tem que assinar termo de responsabilidade pro pai estar ciente ? Tem, porque tudo pode acontecer... mas é necessário... porque a coisa só na teoria e no papel... cansa...Hoje tem filme, informática, TV... a escola vai ficar nessa mesmice de lousa e giz?”.

Professora.
} 
"Este passeio na mata da Tubaca tem há muito tempo, a gente já viu quando era criança, só que a gente chegava lá jogava a gente lá, agente ficava olhando e vinha embora”. Comerciante.

"Eu acho assim: a oportunidade é ímpar, pra fazer uma coisa assim com conhecimento, com a orientação correta,as crianças vão aprender muito, os professores vão ter oportunidade de estar fazendo uma atividade extra-curricular muito valiosa, eu acho que a gente tem que aproveitar mesmo... A questão é a gente dar continuidade a esse projeto de uma forma bastante planejada, organizada...".

Secretária Municipal de Turismo.

“Eles vão ser parceiros na preservação... Nosso exército tá aumentando porque cada criança que vai lá tenho certeza que é um soldado a mais pra começar a jogar desse outro lado".

Diretor Municipal de infra-estrutura.

\subsubsection{A valiação do processo da pesquisa pelos participantes locais}

Costa-Pinto (2003) apontou duas dimensões atribuídas à participação: uma interior/subjetiva/individual, e outra coletiva/política, que se permeiam e alternam de uma forma complexa ao longo do processo. Embora a realização da atividade nos moldes em que foi planejada e executada já seja um indicador da participação dos envolvidos, outros indicadores foram propostos (Anexo C) com base naqueles utilizados por Storey (2003).

Em relação aos indicadores de participação individual, considera-se que todas as nove pessoas envolvidas mais diretamente com o processo participaram efetivamente das atividades, fazendo perguntas sobre estas e opinando em diversos momentos.

No que se refere ao grau de interação do grupo, pode-se afirmar que foi satisfatório, já que a maioria dos participantes interagiu entre si, sendo até mesmo solidários em alguns momentos. Apenas um integrante, embora presente em todos os encontros, dificilmente se manifestava nas reuniões, talvez por timidez. Ainda assim, em conversas informais com a pesquisadora, especialmente na etapa de visita dos estudantes à trilha, ele expôs sua opinião a respeito do processo, sugerindo formas de lidar com as dificuldades encontradas e manifestando grande interesse na continuidade do trabalho e no desenvolvimento de novas trilhas no local, principalmente relacionadas a temas históricos.

O grupo focal nesta etapa, teve como objetivo compreender como os participantes perceberam o processo de participação de uma pesquisa científica. O roteiro de questões utilizado durante a discussão se encontra no Apêndice K. 
As avaliações participativas podem oferecer excelentes oportunidades para a autoaprendizagem de todas as pessoas envolvidas no processo (TILBURY, 2003). Porém, os participantes encontraram dificuldade em responder às questões relativas ao processo do trabalho em grupo. De fato, essas questões exigem uma reflexão mais profunda a respeito do papel de cada indivíduo dentro de um grupo, das dificuldades nas relações interpessoais, entre outras. É comum tentar ignorar os conflitos e problemas existentes nessas relações.

A avaliação também pode ter sido prejudicada pela ausência de dois integrantes cuja contribuição foi fundamental para o desenvolvimento do trabalho, em virtude de seus papéis de "aglutinadores" dos componentes do grupo. No momento da avaliação estavam afastados das suas funções iniciais em conseqüência de mudanças no cenário político municipal.

Todos os participantes presentes afirmaram estar bastante satisfeitos com o projeto. Suas expectativas citadas anteriormente, que incluíam a elaboração de uma trilha interpretativa do meio com finalidades educativa e turística visando à conservação ambiental foram atingidas.

\footnotetext{
"Esse é o objetivo do que a gente quer formatar aqui. A prefeitura vai dar um apoio para que as coisas pudessem acontecer, como é o roteiro da pinga... No primeiro roteiro, no segundo, terceiro nós vamos organizar alguns passeios, mas vai chegar uma hora que a gente passa isso para uma agência de viagens, e o turista que chegar aqui vai lá e... 'tenho esse roteiro, tenho esse passeio, custa tanto e é só agendar'. É assim que ...o turismo vai começar a ser desenvolvido na cidade. Esse investimento que a gente está fazendo com os alunos é porque o aluno de hoje vai ser o político de amanhã e ele vai conscientizando, ele vai sensibilizando o pai, o vizinho, o amigo, para que essas coisas existam aqui em São José de repente não precisa pensar que tem que ir num acampamento não sei aonde, na Serra da Mantiqueira para fazer uma trilha... Aqui tem!".

Secretária Municipal de Turismo.
}

“Eles vão ser parceiros na preservação... Nosso exército tá aumentando porque cada criança que vai lá tenho certeza que é um soldado a mais pra começar a jogar desse outro lado...".

Diretor Municipal de infra-estrutura.

Os participantes também se consideram aptos a conduzir visitantes pela trilha da Tubaca, bem como a elaborar roteiros para outras trilhas já existentes no município.

\footnotetext{
"Foi muito bom tanto é que essa é a única trilha formatada que a gente tem, e nós da [agência de esportes de aventura] estamos totalmente aptos para qualquer outra classe, qualquer outra escola que quiser fazer essa experiência gente tá pronto pra desenvolver a trilha... eu achei maravilhoso, eu curti, como eu falei...”. Empresário de uma agência de esportes de aventura.
} 
“Essa aqui é o primeiro passo, a primeira [trilha] formatada, eu acredito que vão ter mais, claro, existe inúmeras trilhas aqui em São José, a gente conhece bastante, mas é que é aquela coisa: depende de autorização do proprietário, depende de formatar, depende... então precisa trabalhar uma e então 'é isso?'... 'deu certo?', vamos começar dessa aqui a tirar idéias e fazer...porque outras trilhas a gente já conhece, só falta, lógico, colocar tudo...".

Empresário de uma agência de esportes de aventura.

Os integrantes do grupo avaliam como boa sua participação no processo do trabalho como um todo. Eles alegam que participaram ativamente da elaboração do roteiro da trilha, inclusive tendo a oportunidade de avaliar suas sugestões na prática.

“...teve uma trilha que a gente pegou e não continuou, nós achamos melhor voltar... lembra

? Teve uma que nós fomos ate o final da mata em vez da gente andar os 900 metros que faltava, nós voltamos, depois nós chegamos à conclusão que não compensava... a gente acaba voltando $1 \mathrm{~km}$ de mata, mais $1 \mathrm{~km}$ pra chegar no ônibus, na verdade a gente andou 1 $\mathrm{km}$ a mais sem ter necessidade e ainda passando por um caminho que a gente já tinha passado... O legal da trilha é você fazer uma alça, você ir num lugar e chegar por outro, você ir e voltar pelo mesmo caminho ela já fica mais monótona... Acho que participamos bastante..."

Empresário de uma agência de esportes de aventura.

No que tange às facilidades encontradas pelos participantes durante o processo, podemos citar a experiência prévia da maioria em trabalhos em grupo.

\begin{abstract}
"A gente sempre depende um do outro. O nosso lema já é uma equipe, e a gente prega isso também. A gente faz um trabalho com empresas, e às vezes o grupo de vendas da empresa está desunido, então o nosso trabalho é unir. A gente coloca eles dentro de um bote e fala: "vocês são uma equipe, se um remar fora, a equipe inteira ... Então, quer dizer, a gente ensina eles a trabalhar em (...) a cooperação entre o grupo é muito importante”. Empresário de uma agência de esportes de aventura.
\end{abstract}

Um dos integrantes também acredita que o sucesso do trabalho pode ser vinculado, em parte, ao fato de todos eles, ou pelo menos a maioria deles, possuírem os mesmos objetivos e interesses - o que facilitou a união e articulação do grupo.

\footnotetext{
"Acho que não porque acho que a meta de todo mundo era a mesma, mesmo objetivo, então percebe-se esse ano que toda vez que nós formamos um grupo... esse é o caminho: um depender do outro".

Diretor Municipal de infra-estrutura.
}

De fato, a própria formação do grupo facilitou seu engajamento no trabalho, já que os envolvidos identificaram-se imediatamente com o tema e com a proposta, não apresentaram opiniões muito conflitantes e já tinham afinidades pessoais entre si, de maneira que não encontraram grandes dificuldades em participar do projeto. 
"E convidar quem gosta de fazer isso porque às vezes a gente faz o convite pra pessoa errada, na hora errada e aí não anda o projeto, não vai funcionar o projeto se não escolher as pessoas que gostam desse tipo de trabalho...”.

Professora.

“... tem que ter um engajamento de quem quer fazer... tem que conscientizar que tem que montar uma equipe e batalhar mesmo porque não é só 'ah, vamos fazer'... vão ter empecilhos e é o tal negócio: tem que querer fazer por querer fazer...”.

Biólogo e agricultor.

Em relação aos obstáculos encontrados durante o processo de desenvolvimento das atividades, a coordenadora da escola participante do trabalho alegou que os professores tiveram dificuldade em se envolver com o projeto em função da época do ano em que este foi realizado (final do ano letivo). De qualquer forma, ela acredita que esta atividade deva ter uma continuidade.

\footnotetext{
"Acho que o que atrapalhou um pouco foi a época, principalmente as últimas turmas... mas acho que foi bem válido... alguns alunos já conheciam, a gente já havia feito um trabalho de coleta de sementes... então, alguns alunos, que acho que tiveram maior facilidade já tinham consciência do local, alguns era a primeira vez, então acho que por isso que surgiu essa euforia, mas eles vieram comentando 'quando que nós vamos voltar?'... Então a gente percebeu que tem que ter uma continuidade sim... Acredito que acontece a pequenos passos porque a conscientização acho que ela é lenta, mas a gente não deve desistir a gente tem que acreditar, principalmente o professor tem que acreditar no trabalho...".

Coordenadora pedagógica.
}

Segundo os participantes do projeto, a maior importância deste está na interação entre os diversos segmentos em uma única atividade, possibilitando um estreitamento das relações e do diálogo entre eles.

\footnotetext{
“...porque trabalhar fragmentado não funciona. A [agência] faz um trabalho lindo, maravilhoso. A escola faz, outro faz, todo mundo faz, todo mundo faz, mas tudo picadinho, tudo fracionado...Se a gente não se juntar... que nem, pra mim hoje foi uma surpresa estar aqui nessa roda... porque a gente as vezes fala sozinho, né ? Vocês falam sozinhos. A gente se sente órfão".

Professora.
}

Apesar de terem sido constatados, logo no início do processo, um desejo e uma necessidade grande dos participantes em fomentar o turismo de natureza através da implantação de trilhas no município, a presente proposta foi identificada como o motivo da mobilização do grupo. 


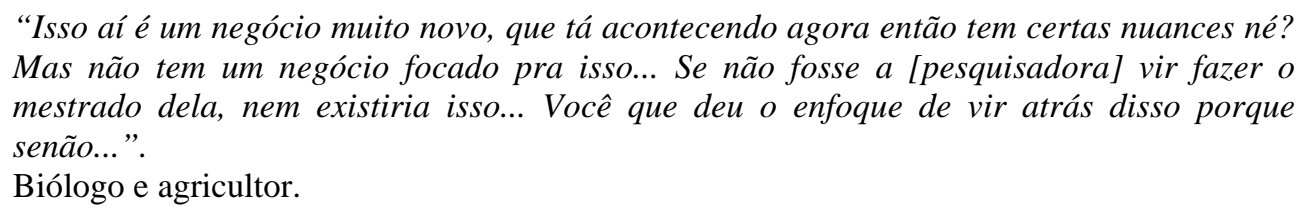

A participação dos integrantes nas diversas etapas do processo e, principalmente suas explanações durante a avaliação deste, sugerem que eles tenham, de fato, se envolvido com a proposta inicial da pesquisadora.

Dentre os presentes na última reunião, o empresário da agência de esportes e aventura se destacou, em virtude de uma postura bastante positiva no que tange à pesquisa. Além de explicar pessoalmente o projeto àqueles que ainda não o conheciam, esclarecer as dúvidas que surgiam e expor as dificuldades, buscando soluções conjuntas, ele apresentou uma proposta de continuidade das atividades que vinham sendo desenvolvidas, e se comprometeu diante de todos os presentes com esta.

\footnotetext{
"A gente da [agência de esportes de aventura] está à disposição para qualquer escola que quiser fazer esse trabalho aí de levar... Esse projeto ... a Rastro vai dar continuidade, que é uma trilha ... durante a semana, durante a aula seria uma aula, né, aí a gente leva...”. Empresário de uma agência de esportes de aventura.
}

Como já dito anteriormente, a então Secretária Municipal de Turismo também se propôs a auxiliar no planejamento e na organização das atividades nas etapas seguintes do projeto.

\footnotetext{
"Eu acho assim: A oportunidade é ímpar, pra fazer uma coisa assim com conhecimento, com a orientação correta, as crianças vão aprender muito, os professores vão ter oportunidade de estar fazendo uma atividade extra-curricular muito valiosa, eu acho que a gente tem que aproveitar mesmo... A questão é a gente dar continuidade a esse projeto de uma forma bastante planejada, organizada...”.

Secretária Municipal de Turismo.
}

A intenção em dar continuidade às atividades com os estudantes, apresentada pelo grupo diante do interesse manifestado pelos representantes das escolas presentes, aponta na direção de uma autonomia do grupo em relação à presença da pesquisadora.

Apesar dessa constatação, durante o processo e no prazo de dois meses após a última reunião realizada com a presença da pesquisadora, não foi feita nova reunião entre os participantes para dar prosseguimento ao trabalho, bem como novas visitas à trilha com grupos de estudantes. 
Além da continuidade das visitas dos alunos à trilha da Tubaca, os participantes intentam elaborar roteiros para novas trilhas. Outra proposta é a construção e transformação de áreas verdes urbanas em locais com finalidade de lazer e recreação para a comunidade.

\footnotetext{
"A prefeitura gostaria que o município tivesse várias trilhas. Essa da Tubaca é uma trilha já conhecida porque o lugar é muito, muito bonito e há alguns anos já vem sido freqüentado...”.

Secretária Municipal de Turismo.
}

Os representantes da agência de esportes e aventura presentes afirmaram que planejam continuar trabalhando com atividades educativas no meio natural, e que uma das propostas consiste em dar aulas percorrendo um trecho do rio Pardo em botes de rafting.

\footnotetext{
“A gente também tá tentando fazer um projeto aí na Rastro, de dar aula em cima do bote de rafting. Em São Luis do Paraitinga eles já fazem isso. O cara falou que dá muito certo, vai de dez botes, junta tudo, a professora vai num bote...".

Comerciante e guia de agência de esportes e aventura.
}

O representante da Secretaria Municipal de Agricultura e Meio Ambiente no Comitê da Bacia do Pardo sugeriu ao grupo que fosse feita uma proposta ao Comitê para financiamento do projeto nas próximas etapas.

"Vocês podiam pensar em transformar esse trabalho num projeto... fazemos parte do comitê de bacia do Pardo, então tem 70\% saneamento, 30\% para as entidades civis, pra principalmente pra projeto ambiental. Seria muito bem visto isso... transformar isso num projeto bem elaborado com planejamento de custo, tudo certinho...”.

Agrônomo. 



\section{CONSIDERAÇÕES FINAIS}

Geralmente não é possível fazer um planejamento prévio de todas as etapas de um processo participativo de forma que a reflexão acabe permeando todas as suas fases como forma de conduzi-lo. É necessário que o pesquisador utilize métodos e técnicas bastante flexíveis, a fim de permitir uma adaptação às situações inesperadas que porventura venham a ocorrer no processo.

A formação e atuação do grupo de participantes de São José do Rio Pardo durante o processo desta pesquisa foram facilitados por vários fatores, dentre eles o fato de uma das pesquisadoras do grupo ser membro da comunidade local, promovendo um primeiro contato com alguns interessados no trabalho.

O modo pelo qual o grupo foi formado, ou seja, por meio de convites feitos pelos próprios participantes àqueles que julgavam ter perfil para esse trabalho, fez com que a maioria deles tivesse certa proximidade e afinidade entre si, além de interesses comuns no desenvolvimento do projeto. Porém, embora tenha facilitado sobremaneira o desenvolvimento da pesquisa, especialmente pelo fato da pesquisadora não estar inserida na realidade local, essa forma de organização do grupo pode ter excluído outros interessados no projeto, mas que talvez tivessem pequena proximidade ou afinidade com tais participantes.

O nível de participação dos integrantes não é constante em todas as etapas do trabalho, já que está sujeito a várias influências, tais como: objetivos e características do processo, interesses e motivações dos envolvidos e relações pessoais entre eles.

$\mathrm{O}$ interesse inicial do grupo pelo tema foi fundamental para proporcionar seu engajamento. Sua articulação durante todas as etapas do trabalho, o apoio - tanto intelectual como logístico - e também a experiência prévia de trabalho em grupo nos ambientes profissionais de alguns integrantes, foram de extrema importância para o desenvolvimento da pesquisa. 
A questão ambiental foi mais facilmente associada aos problemas do que às potencialidades do meio. A maioria dos problemas identificados referia-se àqueles com impactos diretos no meio natural. Já as potencialidades incluíram aspectos históricos e culturais, bem como elementos naturais já transformados ou úteis para os seres humanos.

A biodiversidade, em princípio encarada como uma potencialidade municipal, revela-se, nesse contexto, também como um problema, pois muitos dos problemas municipais citados incidem diretamente sobre ela. Além disso, embora envolvidos em maior ou menor grau com a questão ambiental em função de seus cargos ou profissões, os participantes praticamente não conhecem exemplos de biodiversidade local.

A visita a uma trilha interpretativa trouxe aos estudantes de ensino fundamental, a possibilidade de ampliarem conhecimentos relativos aos conteúdos abordados na atividade, especialmente no que se refere à conservação da biodiversidade. Porém, o que ficou mais evidente na avaliação da atividade com estes estudantes foi a percepção destes em relação à experiência vivida em contato direto com o meio natural e, principalmente, a interação com os colegas e com os monitores. Esse é um resultado muito importante, já que as relações das pessoas em grupos, o diálogo e o respeito ao diverso são alguns valores muito importantes a serem resgatados em processos de educação ambiental.

Dessa forma, a estratégia "trilha" consiste em uma estratégia educativa que transcende os aspectos cognitivos da aprendizagem, proporcionando oportunidades de desenvolvimento de aspectos afetivos e habilidades, podendo assim, ser considerada um instrumento efetivo de educação ambiental.

Porém, essas atividades de visitas às trilhas por alunos de ensino fundamental (e eventualmente médio) devem ser planejadas e consideradas como parte de um processo mais amplo de educação ambiental, e suas contribuições devem ser aproveitadas ao máximo. No entanto, para que isso ocorra, é fundamental que os professores desses alunos sejam formados para atuar com tal estratégia educativa. Pelo fato da relação professor-aluno ser contínua ao longo do ano letivo e, em muitas vezes, ao longo de várias séries escolares, o educador possui maiores possibilidades de desenvolver outras atividades relacionadas às visitas à trilha em momentos anteriores e posteriores a estas, dentro e fora da sala de aula, permitindo que essa atividade não se caracterize como um evento pontual no processo educacional dos estudantes. 
Embora os participantes tenham demonstrado grande interesse na continuidade das atividades, manifestada durante todas as etapas do processo e, principalmente, em sua avaliação, quando não há a presença da pesquisadora, supõe-se que exista certa dificuldade na concretização desta intenção.

Outra dificuldade encontrada na continuidade de projetos participativos, quando envolvem-se esferas públicas, está relacionada às mudanças no cenário político sob o qual o projeto tenha sido elaborado.

Especialmente neste caso, alguns dos participantes do curso de formação de monitores ambientais que tinham intenção de multiplicar idéias e práticas conservacionistas foram afastados de seus cargos junto ao Poder Público, o que pode ter comprometido sobremaneira a continuidade do projeto e o seu desdobramento em outras ações. Percebe-se, assim, a importância da participação de representantes também da esfera privada e do terceiro setor no processo, a fim de promover a continuidade do trabalho em cenários políticos desfavoráveis.

Em relação ao grupo de participantes do processo de construção da trilha, notamse resultados positivos no trabalho. Dentre eles podem ser citados a criação de uma trilha interpretativa com finalidades educativa e turística, e a possibilidade de formação de monitores ambientais para atuarem nas visitas. Porém, talvez o maior benefício proporcionado pelo projeto tenha sido a possibilidade de integrar representantes de diferentes instituições em um trabalho conjunto com enfoque ambiental, como forma de incrementar sua capacidade de movimento e articulação, apoiando o fortalecimento de suas organizações.

Por fim, um processo participativo de construção de uma estratégia educativa pode ser considerado um processo de educação ambiental, na medida em que permite uma reflexão, tanto individual quanto coletiva, a respeito de temas ambientais relevantes; trabalha a convivência em grupo entre pessoas com visões de mundo e opiniões distintas, de forma a exercitar o respeito pelas diferenças, a capacidade de negociação e a tomada de decisões em conjunto; além de aumentar as possibilidades de sua continuidade, gerando autonomia dos participantes e criando oportunidades de novas iniciativas de ações de conservação e educação ambiental por parte dos envolvidos. 



\section{RECOMENDAÇÕES}

Durante o desenvolvimento deste trabalho notou-se que são raros os relatos de pesquisas relativas à área ambiental, conduzidas no município. Assim, há necessidade de se desenvolver estudos diagnósticos do grau de degradação dos fragmentos florestais locais, com finalidade de subsidiar estratégias de conservação e recuperação ecológica destes.

Quanto ao fragmento de mata ciliar utilizado na construção da presente trilha e localizado na fazenda Tubaca, recomenda-se um manejo florestal com a finalidade de minimizar as perturbações existentes, tais como a presença de clareiras e o efeito de borda. A iniciativa de transformar esse fragmento em uma categoria de Unidade de Conservação de uso sustentável (RPPN) é louvável, já que possibilitaria a captação de recursos financeiros junto ao governo e à iniciativa privada para sua conservação.

Em relação à continuidade da ação educativa iniciada neste trabalho, recomendase envolver os estudantes de outras escolas do município nas atividades de visita à trilha da Tubaca, bem como formar seus professores de maneira que eles possam aproveitar ao máximo as contribuições desse tipo de atividade para o desenvolvimento de outras, dentro e fora da sala de aula. Preparados para tratar de questões relativas ao tema ambiental, os educadores terão condições, não só de aplicar esses conhecimentos ao cotidiano escolar, como também de desenvolver novos projetos que ampliem as discussões a respeito dessa temática com a comunidade do entorno da escola.

Durante a etapa de diagnóstico, muitos temas levantados foram considerados relevantes no contexto local pelo grupo de participantes e, embora alguns desses temas tenham sido utilizados na presente intervenção educativa, vários outros merecem ser tratados em futuros projetos, tanto de pesquisa, quanto educativos e de conservação e/ou manejo.

Um dos temas que mais chama a atenção no contexto local é a questão dos resíduos sólidos. Embora já exista um trabalho de coleta seletiva no município, a adesão 
da comunidade ainda é muito pequena e acredita-se que o principal motivo seja a falta de uma intervenção educativa associada ao projeto de gerenciamento dos resíduos implantado. A população precisa ser sensibilizada e conscientizada, não só a respeito de como proceder na separação dos materiais recicláveis, mas também da importância em diminuir a geração de resíduos, e/ou reaproveitá-los para outros fins.

O tema biodiversidade, tratado na presente pesquisa/intervenção, merece ser aprofundado em discussões, ações e pesquisas posteriores devido à sua importância e complexidade. Também é importante que esses dados sejam divulgados para a comunidade em geral através de programas educativos centrados neste tema, como forma de contribuição para o conhecimento e a valorização da conservação desses aspectos em âmbito local.

Outras trilhas também podem ser criadas, especialmente na área urbana, como forma de reconhecer, apreciar e conservar a biodiversidade, presente também neste ambiente. 


\section{REFERÊNCIAS}

AB'SABER, A.N. (2000). O suporte geoecológico das florestas beiradeiras (ciliares). In: RODRIGUES, R.R.; LEITÃO FILHO, H.F. Matas ciliares: conservação e recuperação. São Paulo: EDUSP/FAPESP. p.15-25.

ANADÓN, M. (2003). Quando avaliar é formar. In: SANTOS, J.E.; SATO, M. A contribuição da educação ambiental à esperança de Pandora. 2.ed. São Carlos: RiMa. p.559-568.

ANDRADE, A.L.C.; LOUREIRO, C.F.B. (2003). Monitoramento e avaliação de projetos em educação ambiental: uma contribuição para o desenvolvimento de estratégias. In: SANTOS, J.E.; SATO, M. A contribuição da educação ambiental à esperança de Pandora. 2.ed. São Carlos: RiMa. p.511-530.

ATAIDE, S.F. et al. (2002). Educação ambiental e conservação da biodiversidade: a experiência dos povos do parque indígena do Xingu. In: BENSUSAN, N. (Org.). Seria melhor mandar ladrilhar? Biodiversidade como, para que, por quê? Brasília: Ed.Universidade de Brasília; Instituto Socioambiental.

BOZZINI, A.C. (1996). Subsídios para o planejamento do parque municipal da mata da “paixão" São José do Rio Pardo, SP. 105 p. Monografia (Conclusão de curso) - Instituto de Biociências, Uiversidade Estadual Paulista, Rio Claro, 1996.

BRINKER, J.M.O.P. (1997). Possibilidades de ensino e aprendizagem de ciências biológicas a partir de situações existentes numa trilha ecológica. 158p. Dissertação (Mestrado) - Universidade Federal de São Carlos, São Carlos, 1997.

CABRAL, L.O.; BUSS, M.D. (2001). A paisagem como campo de visibilidade e de significação, estudo de caso. Percepção Ambiental: a interdisciplinariedade no estudo da paisagem, OLAM - Ciência \& Tecnologia, Rio Claro, v.1, n.2, p.166-186, nov. 
CAStello, L. (2001). Percepção do ambiente educando educadores. Percepção Ambiental: a interdisciplinariedade no estudo da paisagem, OLAM - Ciência \& Tecnologia, Rio Claro, v.1, n.2, p.153-165, nov.

CATALDI, N.L. (1994). Treinamento em unidades de conservação. Não publicado.

CAVALLINI, M.M. (2001). Agricultura tradicional, composição paisagística e conservação da biodiversidade na região sul mineira: subsídios ao desenvolvimento rural sustentável. 174p. Tese (Doutorado) - Universidade Federal de São Carlos, São Carlos, 2001.

CENTRO DE ESTUDOS E PESQUISAS AMBIENTAIS (2001). Trilhas de interpretação da natureza. Poços de Caldas: ALCOA.

CHAMBERS, R. (1994). The origins and practice of participatory rural appraisal. World Development, Oxford, v.22, n.7, p.953-969, July.

CORNELL, J. (1996). Brincar e aprender com a natureza: guia de atividades infantis para pais e monitores. 2.ed. São Paulo: Companhia Melhoramentos; Ed.SENAC.

COSTA- PINTO, A.B. (2003). Em busca da potência de ação: educação ambiental e participação na agricultura caiçara no interior da área de proteção ambiental de Ilha Comprida, SP. 209p. Dissertação (Mestrado) - Programa de Pós Graduação em Ciência Ambiental, Universidade de São Paulo, São Paulo, 2003.

DEL GUERRA, R.J. (1999). A São José, una nuova storia. São Sebastião da Grama: Grass.

DEPRESBÍTERIS, L. (2003). Avaliação da aprendizagem na educação ambiental: uma relação muito delicada. In: SANTOS, J.E.; SATO, M. A contribuição da educação ambiental à esperança de Pandora. 2.ed. São Carlos: RiMa. p.531-557. 
DOYLE, R.; KRASNY, M. (2003). Participatory rural appraisal as an approach to environmental education in urban community gardens. Environmental Education Research, Reading, v.9, n.1, p.91-115.

EHRLICH, P.R. (1997). A perda da diversidade: causas e conseqüências. In: WILSON, E.O.; PETER, F.M. (Ed.). Biodiversidade. Tradução de Marcos Santos; Ricardo Silveira. Rio de Janeiro: Nova Fronteira.

FARIA, A.A.C. (2000). O uso do diagnóstico rural participativo em processos de desenvolvimento local: um estudo de caso. Dissertação (Mestrado) - Universidade Federal de Viçosa, Viçosa, 2000.

FERREIRA, M.A.V. (2002). Uma análise dos olhares dos moradores e da imprensa escrita sobre a degradação do rio Pardo no município de São José do Rio Pardo, SP. Dissertação (Mestrado) - Escola de Engenharia de São Carlos, Universidade de São Paulo, São Carlos, 2002.

FERREIRA, M.A.V.; OLIVEIRA, H.T. (2001). Análise dos conceitos e percepções de alunos da $8^{\mathrm{a}}$ série do ensino fundamental sobre o rio Pardo, no município de São José do Rio Pardo, SP. In: REUNIÃO ANUAL DA ANPED, 24., 2001, Caxambu. Anais eletrônicos... Disponível em:〈www.anped.org.br>. Disponível em: 10 out. 2003.

FERREIRA NETO, P.S. (2004). Curso diagnóstico participativo de comunidades rurais e tradicionais. Nazaré Paulista: Instituto de Pesquisas Ecológicas. Apostila.

GAJARDO, M. (1986). Pesquisa participante na América Latina. São Paulo: Brasiliense.

GASKELL, G. (2003). Entrevistas individuais e grupais. In: BAUER, M.W.;

GASKELL, G. Pesquisa qualitativa com texto, imagem e som: um manual prático. 2.ed. Local: Vozes. p.64-89.

GAYFORD, C. (2000). Biodiversity education: a teacher's perspective.

Environmental Education Research, Reading, v.6, n.4, p.347-361. 
GONÇALVES, C.W.P. (1990). Os (des) caminhos do meio ambiente. 2.ed. São Paulo: Contexto.

HAGVAR, S. (1994). Preserving the natural heritage: the process of developing attitudes. Ambio, Stockholm, v.23, n.8, p.515-518.

HAM, S.H. (1992). Interpretación ambiental: uma guia práctica para gente com grandes ideas e pressupuestos pequeños. Colorado: North American Press Golden.

HAM, S.H.; SUTHERLAND, D.S.; MEGANCK, R.A. (1993). Applying environmental interpretation in protected areas of developing countries: problems in exporting a US model. Environmental Conservation, Lausanne, v.20, n.3, p.232-242.

ILTIS, H.H. (1997). Descobertas fortuitas na exploração da biodiversidade: quão bons são os tomates mirrados? In: WILSON, E.O.; PETER, F.M. (Ed.). Biodiversidade. Tradução de Marcos Santos; Ricardo Silveira. Rio de Janeiro: Nova Fronteira.

INSTITUTO DE PESQUISAS TECNOLÓGICAS (2001). Relatório zero. Comitê de Bacia Hidrográfica do Pardo. Disponível em:<http://www.sigrh.sp.gov.br/cgibin/sigrh_cgi.exe/Documentos?Comite=CRH/CBHPARDO\&Grupo=Relatório\%20Zero>. Acesso em: 28 fev. 2004.

KITZINGER, J.; BARBOUR, R.S. (1998). Introduction: the challenge and promise of focus groups. In: BARBOUR, R.S.; KITZINGER, J. Developing focus groups research: politics, theory and practice. London: Sage. p.1-20.

KRUEGER, R.A. (1994). Focus groups: a practical guide for applied research. 2.ed. Thousand Oaks: Sage.

LIMA, W.P.; ZAKIA, M.J.B. (2000). Hidrologia de matas ciliares. In: RODRIGUES, R.R.; LEITÃO FILHO, H.F. Matas ciliares: conservação e recuperação. São Paulo: EDUSP/FAPESP. p.33-44. 
LUDKE, M.; ANDRÉ, M.E.D.A. (1986). Pesquisa em educação: abordagens qualitativas. São Paulo: EPU.

MAGRO, T.C. (1999). Impactos do uso público em uma trilha no planalto do Parque Nacional do Itatiaia. 135p. Tese (Doutorado) - Escola de Engenharia de São Carlos, Universidade de São Paulo, São Carlos, 1999.

MARKWELL, K. (1996). Challenging the pedagogical basis of contemporary environmental interpretation. Australian Journal of Environmental Education, Australia, v.12, p.9-14.

MATAREZI, J. (2001). Trilha da vida: re-descobrindo a natureza com os sentidos. In: CONGRESSO DE EDUCAÇÃO AMBIENTAL NA ÁREA DO PRÓ-MAR-DEDENTRO, 2001, Rio Grande. Anais revista eletrônica do MEA... Rio Grande: FURG. Disponível em:<http://www.sf.dfis.furg.br/mea/remea/congress/artigos/minicurso01.pdf $>$. Acesso em: 26 maio 03.

MAYER, M. (1998). Educación ambiental: de la acción a la investigación. Enseñanza de las Ciencias, Barcelona, v.2, n.16, p.217-231.

MINISTÉRIO DO MEIO AMBIENTE (2000). Convenção sobre diversidade biológica. Brasília-DF.

MORAES, W.V. (2000). Ecoturismo: capacitação de profissionais. Viçosa: Aprenda Fácil.

MURPHY, D.D. (1997). Desafios à diversidade biológica em áreas urbanas. In: WILSON, E.O.; PETER, F.M. (Ed.). Biodiversidade. Tradução de Marcos Santos; Ricardo Silveira. Rio de Janeiro: Nova Fronteira.

OLIVEIRA, H.T. (2004). (Bio)diversidade, sustentabilidade e solidariedade: conceitos centrais para a formação de educadores ambientais. In: SEMINÁRIO 
PLURICULTURALISMO Y GLOBALIZACIÓN: producción del conocimiento para la construcción de la ciudadanía en Latinoamérica, 9., 2004, Barcelona. Anais... p.57-62.

OLIVEIRA, L. (2001). Percepção do meio ambiente e geografia. Percepção Ambiental: a interdisciplinariedade no estudo da paisagem, OLAM - Ciência \& Tecnologia, Rio Claro, v.1, n.2, p.14-18, nov.

OLIVEIRA, R.D.; OLIVEIRA, M.D. (1981). Pesquisa social e ação educativa: conhecer a realidade para poder transformá-la. In: BRANDÃO, C.R. (Org.). Pesquisa participante. São Paulo: Brasiliense.

OKSANEN, M. (1997). The moral value of biodiversity. Ambio, Stockholm, v.26, n.8, p.541-545.

PLOTKIN, M.J. (1997). A perspectiva para novos produtos agrícolas e industriais dos trópicos. In: In: WILSON, E.O.; PETER, F.M. (Ed.). Biodiversidade. Tradução de Marcos Santos; Ricardo Silveira. Rio de Janeiro: Nova Fronteira.

REIGOTA, M. (1995). Meio ambiente e representação social. São Paulo: Cortez.

RIBEIRO, I.C. (2003). Educação para a vida: uma experiência metodológica. 298p. Tese (Doutorado) - Universidade Federal de São Carlos, São Carlos, 2003.

ROBOTTOM, I.; HART, P. (1993). Research in environmental education: engaging the debate. Univerity and Griffith University. Deakin University Press: Victoria.

ROBOTTOM, I.; SAUVÉ, L. (2003). Reflecting on participatory research in environmental education: some issues for methodology. Canadian Journal of Environmental Education, Whitehorse, v.8, p.1-19.

RODRIGUES, R.R.; NAVE, A.G. (2000). Heterogeneidade florística das matas ciliares. In: RODRIGUES, R.R.; LEITÃO FILHO, H.F. Matas ciliares: conservação e recuperação. São Paulo: EDUSP/FAPESP. p.45-71. 
SATO, M.; SANTOS, J.E. (1998). Cual educación ambiental? Revista de Educación en Biología, v.2, n.1, p.12- 21.

SAUVÉ, L. (2003). Perspectivas curriculares para la formación de formadores en educación ambiental. In: FORO NACIONAL SOBRE LA INCORPORACIÓN DE LA PERSPECTIVA AMBIENTAL EN LA FORMACIÓN TÉCNICA Y PROFESIONAL, 2003, México. Anais... México: Universidad Autónoma de San Luis Potosí. 1Cd-Rom.

SECRETARIA DE ESTADO DO MEIO AMBIENTE (1997). Cerrado: bases para conservação e uso sustentável das áreas de cerrado do Estado de São Paulo. São Paulo: SMA. (Documentos Ambientais).

SENICIATO, T.; CAVASSAN, O. (2003). Para além da razão. In: TALAMONI, J.L.B.; SAMPAIO, A.C. (Org.). Educação ambiental: da prática pedagógica à cidadania. São Paulo: Escrituras. p.41-57.

SILVA, N.R.S.; MARTINS, S.V. (2001). Considerações sobre conservação e restauração de fragmentos florestais. Folha Florestal, n.99, p.7-8.

SORRENTINO, M. (1998). De Tbilisi a Thessaloniki: a educação ambiental no Brasil. In: CASCINO, F.; JACOBI, P.; OLIVEIRA, J.F. (Org.). Educação, meio ambiente e cidadania - reflexões e experiências. São Paulo: SMA/CEAM. p.27-32.

STOREY, C. (2003). Representações sociais e meio ambiente: participação de um grupo de mulheres no planejamento de uma intervenção de educação ambiental popular urbana em Manaus, Amazonas. 189p. Tese (Doutorado) - Universidade Federal de São Carlos, São Carlos, 2003

TABANEZ, M.F. et al. (1997). Avaliação de trilhas interpretativas para educação ambiental. In: PÁDUA, S.M.; TABANEZ, M.F. (Org.). Educação ambiental: caminhos trilhados no Brasil. Brasília: IPE. p.89-102.

THIOLLENT, M. (2000). Metodologia da pesquisa-ação. 10.ed. São Paulo: Cortez. 
TILBURY, D. (1998). Investigación sobre evaluación en educación ambiental. In: JORNADAS DE EDUCACIÓN AMBIENTAL, 3., 1998, Pamplona. Anais eletrônicos... Disponível em:<http://www.mma.es/educ/ceneam/10documentos/jornadas/evaluacion1.htm>. Acesso em: 25 jul. 04.

TILDEN, F. (1967). Interpreting our heritage. Chapel Hill: The University of Carolina Press.

TUAN, Y.F. (1980). Topofilia: um estudo da percepção, atitudes e valores do meio ambiente. São Paulo: DIFEL.

VIANNA, V.M.; TABANEZ, A.J.A.; MARTINEZ, J.L.A. (1992). Restauração e manejo de fragmentos florestais. Revista do Instituto Florestal, São Paulo, v.4, n.2, p.400-406, mar. Apresentado ao 2.Congresso Nacional sobre Essências nativas, São Paulo, 1992.

WILSON, E.O. (1997). A situação atual da diversidade biológica. In: In: WILSON, E.O.; PETER, F.M. (Ed.). Biodiversidade. Tradução de Marcos Santos; Ricardo Silveira. Rio de Janeiro: Nova Fronteira. 
APÊNDICE A - Proposta de trabalho apresentada à delegada regional da rede estadual de ensino de São João da Boa Vista - SP.

\section{Definição do estudo:}

É um estudo a ser realizado para a conclusão do curso de Pós Graduação - Mestrado, na área da Educação Ambiental, da Universidade de São Paulo, campus de São Carlos e caracterizada por uma pesquisa participativa, a qual envolve a comunidade estudantil.

\section{Objetivos do trabalho:}

$>\quad$ Identificar as contribuições que uma ONG (Organização Não Governamental) oferece para o planejamento de programas de educação ambiental direcionado à conservação da biodiversidade e ao desenvolvimento da temática ambiental em salas de aulas numa perspectiva socioambiental.

$>\quad$ Mensurar a eficácia educacional de uma estratégia educativa adotada pela ONG em estudo, através da aplicação da mesma metodologia em um contexto fora da área de atuação da Ong avaliada neste estudo.

$>\quad$ Implantar e avaliar de uma trilha interpretativa de forma participativa junto à comunidade estudantil.

Metodologia de Trabalho: Identificar um grupo de 30 professores e 100 alunos para a realização de uma atividade educativa constituída por: a) planejamento participativo do tema ambiental abordado, b) preparação de uma palestra participativa, c) realização de um estudo do meio, d) aplicação de pré e pós-questionários aos participantes.

Período de realização do trabalho: Estima-se que este trabalho irá ocupar não mais que 03 meses de duração para aplicação das atividades.

Área de desenvolvimento do trabalho: São José do Rio Pardo (SP).

Orientadora: Profa. Dra. Haydée Torres de Oliveira - Universidade Federal de São Carlos

Alunas responsáveis pelo estudo: Ariane Di Tullio e Maria das Graças de Souza.

Maiores Informações: EESC - fone: (16) 3373-8253 UFSCAR - fone: (16) 3351-8757 


\section{APÊNDICE B - Roteiro de discussão do grupo focal sobre o tema biodiversidade.}

1. O que vocês entendem por biodiversidade?

2. O que vocês entendem por meio ambiente?

3. O que vocês entendem por educação ambiental?

4. Qual a relevância do tema biodiversidade em processos de Educação Ambiental?

5. A biodiversidade deve ser conservada? Por quê?

6. Pensando no município de São José do Rio Pardo, onde podemos encontrar biodiversidade? Que tipo de diversidade é essa?

7. Existe alguma relação entre diversidade biológica e cultural? (exemplos: alimentação, expressões culturais, religiões, esportes)?

8. Quais aspectos da biodiversidade local são conhecidos? 


\section{APÊNDICE C - Carta e proposta de trabalho apresentada aos administradores da Fazenda Fortaleza}

São Carlos, 08 de junho de 2004.

Ilmo. Sr.

Diretor da Fazenda Fortaleza

São José do Rio Pardo - SP

Ass: Roteiro para Atividade de Educação Ambiental na área da Fazenda Fortaleza

Prezado Senhor;

Encaminhamos o roteiro de atividade para a Caminhada Interpretativa na área de mata da Fazenda Fortaleza, conforme solicitado por Vossa Senhoria na semana passada.

Gostaríamos de informar que o trabalho proposto não inclui em nenhuma etapa a coleta de material biológico da área (sementes, folhas, insetos, madeira, animais, etc.) e caso seja necessário, estamos à disposição para apresentar o trabalho proposto à Diretoria da Fazenda Fortaleza para informar e esclarecer dúvidas que possam surgir em relação à realização do trabalho.

Por último, gostaríamos ainda de informar que caso haja interesse e/ou necessidade por parte da Fazenda Fortaleza, um funcionário da mesma pode estar nos acompanhando durante todas as etapas de realização do trabalho.

Sem mais para o momento, mais uma vez agradecemos a atenção e o apoio, e nos colocamos ao seu inteiro dispor para quaisquer outras informações que julgar necessárias.

Atenciosamente,

Ariane Di Tullio e Maria das Graças de Souza

Alunas do Programa de Pós Graduação - Coordenadoras da atividade educativa

Profa. Dra. Haydée Torres de Oliveira

Orientadora Científica 


\section{Caminhada Interpretativa na mata da Fazenda Fortaleza Roteiro de Atividade}

A caminhada interpretativa a ser realizada na área de mata da Fazenda Fortaleza tem como principal finalidade compartilhar experiências e conhecimentos relacionados ao meio ambiente com um grupo de estudantes, professores e membros da comunidade local.

A área da Fazenda Fortaleza que estamos solicitando para a realização da atividade educativa em planejamento foi escolhida após um trabalho de campo que incluiu várias visitas de diagnóstico. Tal área se encontra em estado considerável de conservação e proteção, contendo uma grande diversidade de espécies vegetais e animais, e constitui para a região um dos fragmentos florestais de grande importância biológica, cultural e ecológica.

Os procedimentos que estão sendo planejados para a caminhada interpretativa na trilha (estamos chamando de trilha o percurso realizado na estrada já existente dentro da área da Fazenda, próxima ao reservatório de água), constarão das seguintes atividades:

1) Definição de alguns pontos estratégicos - dentro da área identificada a ser utilizada para a caminhada - para observação dos ambientes diversificados, como espécies vegetais, pontos atrativos (paisagem, por exemplo), facilidade para caminhada em grupo (usar a estrada antiga já existente), som de pássaros e outros vestígios de animais.

2) Levantamento de informações para subsidiar a caminhada na trilha, tais como: materiais sobre o tipo da vegetação característica da região, fauna local, história da área (Fazenda Fortaleza) e biodiversidade.

3) Visitas de campo com educadores, ambientalistas e professores, através de caminhadas para a definição do local da trilha (total de área a ser percorrida, tipo de informação a ser trabalhada durante a atividade, definição dos pontos interpretativos ou de paradas para a execução das atividades, etc.).

4) Identificação de espécies vegetais do percurso da trilha, utilizando-se do livro "Árvores Brasileiras - Manual de Identificação e Cultivos de Plantas Arbóreas no Brasil” (Lorenzi, 1990).

5) Definição final do roteiro e das informações a serem trabalhadas de forma que ajudasse na realização de atividades interativas junto aos estudantes e professores na observação e na experimentação com o ambiente natural.

6) Realização da caminhada interpretativa junto aos alunos e professores.

Essa atividade será monitorada e levará cerca de três a quatro horas de duração entre a chegada com o grupo na área, caminhada com explicação sobre o ambiente visitado (interpretação ambiental), pausa para lanche e retorno.

7) Entrega de uma cópia do material de informação produzido para a atividade educativa (roteiro interpretativo final) à diretoria da fazenda. 


\section{APÊNDICE D - Artigo sobre potencial turístico da fazenda Santa Teresa publicado no jornal Gazeta do Rio Pardo}

\section{DMEIO AMBIENTE \\ Pesquisadores da UFSCar e USP visitam São José e se surpreendem}

\section{Resumo dos Fatos: \\ - Visitas fazem parte dos trabalhos de dou- torado e mestrado}

- Fazenda Santa Tereza foi considerada de potencial turístico

- Usina do rio do Peixe e antigas colōnias também impressionam

Com a finalidade de realizar um diagnóstico da situaçầo ambiental local para a concretização de atividades de Educaçăo Ambiental em São José do Rio Pardo, pesquisadoras da Universidade de São Paulo Universidade Federal de São Carlos estiveram visitando, nos ültimos meses. diversas áreas de zona rural do municipio. Essa in- vestigação e parte integrante dos trabalhos de doutorado e mestrado das pesquisadoras Maria Alice Vaz Ferreira, da UFSCar, e Maria das Graças de Souza e Ariane Di Tulio, da USP.

A realidade ambiental encontrada nas áreas visitadas foi surpreendente: as porçôes de mata nativa, os trechos preservados do Rio Pardo, seus afluentes e a biodiversidade ali existente, tais como: insetos, aves. plantas e primatas, observados durante as visitas sio aspectos muito importantes a serem considerados em ações de educaçằo, conservaçĩo e turismo.

Um exemplo bastante ilustrativo do grande potencial regional é a Fazenda Santa Tereza, local ideal para a prática do turismo de natureza e ate mesmo do turismo historico, já que alia uma área natural, a um patrimonio histórico e cultural bastante preservados

A fazenda possui morros com trechos de mata nativa preservada, cenário idea para os visitantes que buscam, no contato com a natureza, uma possibilidade de lazer, descanso e relaxamento através de caminhadas em trilhas, banhos de io e cachocira. Outros vi sitantes buscam, nesse contato $\operatorname{com} 0$ meio natural uma oportunidade de am. pliar seus conhecimentos ate de se exercitar, praticando os famosos esportes de aventura, tais como trilhas de moto, passeios a cavalo bicicleta, entre outros. Enfim, muitas são as possibilidades da Fazenda Santa Tereza para aqueles que buscam uma maior integra- çāo com a natureza.

Os aspectos históricos do local também são bastante interessantes: a usina do Rio do Peixe, que entrou $\mathrm{em}$ funcionamento no inicio do século $\mathrm{XX}$, e as ruinas de antigas colonias de trabalhadores da regiào constituem alternativas para possiveis visitas.

A fazenda vem sendo equipada com a infra-estrutura necessária para a recepclo de visitantes, tais como sanitários, restaurante, lanchonete, galpão para eventos, etc. A íniciativa dos proprietários da fazenda, Carlos e Tània, de incentivar a visitação ao local vem sendo apoiada pela Secretaria Municipal de Turismo que tambem acredita no enorme potencial da área cotno atrativo turistico local e ate mesmo regional. 


\section{APÊNDICE E - Roteiro de questões para a primeira revisão do percurso interpretativo da trilha da Tubaca com os participantes.}

1 - Como vocês avaliam o roteiro da trilha proposto? Ele está de acordo com as suas expectativas?

2 - O roteiro da trilha cumpre com os objetivos propostos?

3 - Que outros objetivos podemos propor? Como adaptá-la para que eles sejam cumpridos?

4 - O tema abordado na trilha está claro para os visitantes?

5 - A trilha desperta interesse?

6 - As atividades são envolventes?

7 - A duração da trilha está apropriada?

8 - A extensão da trilha está apropriada?

9 - Quais sugestões vocês gostariam de fazer? 


\section{APÊNDICE F - Roteiro interpretativo para visita guiada à trilha da Tubaca.}

* As visitas à trilha da Tubaca devem ser agendadas com o Sr. Eduardo Dias Roxo Nobre pelo telefone (19)3608-5490.

\section{OBJETIVOS:}

- Criar oportunidade de sensibilizar os visitantes a respeito da complexidade das questões ambientais locais;

- Possibilitar a reflexão e a discussão das questões ambientais locais e regionais mais relevantes,

- Valorizar o conhecimento local,

- Incentivar ações coletivas e individuais de recuperação/ melhoria/ conservação das condições ambientais locais.

TÓPICO: Biodiversidade e Educação Ambiental em São José do Rio Pardo TEMA: A importância do rio Pardo na conservação da biodiversidade local e regional SUB-TEMA 1: A importância do rio Pardo na história e cultura local.

SUB-TEMA 2: A importância da vegetação na conservação do rio e a importância do rio na conservação da vegetação.

SUB-TEMA 3: A importância do solo na conservação da vegetação e a importância da vegetação na conservação do solo.

SUB-TEMA 4: A importância da fauna na conservação da vegetação e a importância da vegetação na conservação da fauna.

\section{PREPARAÇÃO - ESCOLA}

- Apresentar os guias e dar boas vindas;

- Verificar algumas das expectativas dos visitantes (perguntar se eles já entraram em uma mata, o que viram, se gostaram, etc.);

- Enfatizar a experiência de conviver com o ambiente natural e a cultura local (estímulo ao caráter coletivo, colaborativo e não competitivo da atividade);

- Informar como será o passeio (local - Fazenda Tubaca, distância do percurso 2900m, duração da atividade - aproximadamente 2,5h.);

- Informar a respeito do esforço físico necessário, dificuldades e obstáculos;

- Informar a respeito da segurança, equipamentos e materiais necessários (verificar se os visitantes estão devidamente trajados e calçados);

- Recomendações:

- Não sair da trilha e não se afastar do grupo; 
- Lembrar que a mata é a casa de muitos animais e que nós somos os convidados. E como convidados educados, não devemos jogar lixo, arrancar galhos e flores, fazer muito barulho, etc.;

- Não comer durante a trilha; ao final, haverá um tempo para o lanche;

- Aproveitar, observar bem e respeitar o meio ambiente natural.

- Permitir que os visitantes tirem suas dúvidas.

“Na natureza, nada se tira senão fotos, nada se deixa senão pegadas e nada se mata senão o tempo".

\section{INTRODUÇÃO - PONTO 1 - ENTRADA DA FAZENDA TUBACA}

Dizer que estamos na área da Fazenda Tubaca. Perguntar se os visitantes sabem o significado do nome da fazenda. Dizer que Tubaca é um pássaro, também chamado de Tovaca. Falar um pouco sobre a fazenda: ela possui uma área de 2.057 hectares, sendo $25 \%$ desse total coberto por vegetação nativa. A fazenda também possui áreas de pastagens, criação de gado confinado e áreas de cultivo de café. A área de mata utilizada para a atividade constitui-se num trecho remanescente de mata ciliar do rio Pardo que se apresenta bastante conservado e tem uma grande diversidade de espécies, devendo ser conservada.

Recomendações - reforçar as informações sobre segurança, equipamentos, materiais e condutas necessárias.

\section{PONTO 2 - RIO PARDO}

Perguntar aos alunos que rio é esse. Dizer que é o rio Pardo, aquele mesmo que passa lá na cidade, na Ilha de São Pedro, embaixo da ponte Euclidiana.

Fazer a dinâmica do rio "limpo x rio sujo" adaptada. De olhos fechados, perguntar quais são as sensações que mais chamam a atenção (sentir o vento, ouvir o barulho dos pássaros e do rio...). Repetir a mesma pergunta com os visitantes de olhos 
abertos. Pedir para que eles fechem os olhos novamente e imaginem que estão no meio da cidade de São Paulo, às margens do rio Tietê... Só existem prédios, avenidas, carros correndo... Tudo é cinza, não há nenhum verde... Perguntar o que os estudantes sabem sobre o rio que corta essa cidade. Quais sons ouviriam? Quais cheiros sentiriam? Pedir para que comentem as sensações que tiveram.

Informar sobre o rio Pardo: ele nasce na Serra do Cervo, município de Itapiúna (MG) e deságua no rio Grande, que por sua vez deságua no rio Paraná, este deságua no rio Paraguai, que deságua no oceano Atlântico). O rio Pardo faz parte da bacia do Pardo, que banha 23 municípios, dentre eles São José do Rio Pardo. Dizer que com a vida agitada, as pessoas quase sempre passam pelo rio, mas não prestam atenção nele (os visitantes percebem que o rio muda de cor durante o ano? Ele fica mais escuro na época de chuva e mais claro na época de seca).

Perguntar por que eles acham que as pessoas não prestam atenção no rio. Perguntar a respeito da importância dele. Falar da sua importância para os seres humanos (história, cultura e economia local). A água também é importante para a agricultura, pecuária, indústria, uso doméstico (lavar roupa, louça, banho, etc.). Perguntar se eles acham que as pessoas têm consciência dessa importância da água. Por que há tanto desperdício?

Perguntar se os visitantes sabem como era o rio há 40 anos e quem deles já perguntou isso para os avós. Fazer uma breve retrospectiva histórica a respeito do rio Pardo, em relação à quantidade e cor da sua água, quantidade de espécies de peixes e costumes da comunidade ribeirinha (a natação). Comparar a situação passada com a presente e comentar a respeito das atuais ameaças à qualidade das águas do rio Pardo (poluição por esgoto, agrotóxico, construção de barragens, entre outras).

Dizer que o rio Pardo também é importante para os outros seres vivos. Ele é essencial para a vida de muitas outras espécies, tanto de animais quanto de plantas e até mesmo de microorganismos. Todos os seres vivos precisam de água (75\% do nosso corpo é formado por água). Perguntar o que precisa ser feito para conservar o rio Pardo.

Finalizar esse item dizendo que o rio Pardo é muito importante, na história, na economia e na cultura na região, e também é muito importante para a manutenção do equilíbrio ecológico e é papel de todos os cidadãos conservá-lo. Pedir para que os visitantes citem algumas maneiras de conservação do rio e dizer que mais adiante, outras formas de conservação do rio serão abordadas. 


\section{PONTO 3 - AUSÊNCIA DE MATA CILIAR}

Chamar a atenção dos visitantes para os diferentes usos do solo na fazenda que podem ser vistos desse local (áreas de pastagens, criação de gado, construções, mata ciliar).

Explicar que antigamente a mata que se vê ao fundo cobria todo o espaço em que nos encontramos. Porém, o crescimento das cidades, agricultura, pecuária, agrotóxico, fogo, lixo, entre outros, fez com que as áreas de matas naturais diminuíssem ao longo dos anos. Esses pequenos trechos que sobraram devem ser conservados, pois representam uma grande riqueza biológica, cultural e ecológica da nossa região e abrigam grande biodiversidade.

Perguntar o que é uma mata ciliar e se alguém já esteve em uma. Perguntar quais as diferenças dela em relação à área em que estamos, e qual a importância dela para o rio (incluir o aspecto do clima). Dizer que além da poluição do rio pelo esgoto, já comentada, outra ameaça à conservação do rio é a falta de mata ciliar, pois quando chove, a água cai com tanta força no solo que o arrasta para o rio. Esse fenômeno é chamado de assoreamento, e se houver lixo ou agrotóxico no solo, ele também vai ser arrastado para o rio.

Finalizar ressaltando a importância da mata ciliar para a conservação do rio e dizer que mais adiante o grupo vai entrar num trecho de mata ciliar para entender melhor como tudo o que foi dito funciona.

\section{TRAJETO ATÉ A PORTEIRA}

É comum encontrar fezes e pegadas de animais, principalmente capivara e anta nesse trecho.- tirar proveito do inesperado.

Copaíba - (pau d'óleo) - Madeira utilizada na indústria. Do tronco, extrai-se o óleo de copaíba, utilizado para problemas de bronquite, tosse, doenças da pele (urticária). É um ótimo cicatrizante. 


\section{PONTO 4 - ENTRADA DA MATA CILIAR}

Fazer uma pequena retrospectiva sobre a importância de um rio limpo para que os peixes e os outros seres que dependem do rio possam viver. Dizer que, além disso, existe algo muito importante para conservar o rio: a mata ciliar. Falar que a partir desse momento o grupo percorrerá um trajeto dentro da mata. Ouvir os sons (o som dos pássaros é mais perceptível, enquanto o som do rio é menos perceptível). Perguntar por que isso acontece. Sentir a temperatura (mais amena do que fora da mata) Perguntar o porquê.

Informações sobre a mata ciliar: a mata ciliar possui esse nome porque protege o rio assim como nossos cílios protegem os nossos olhos da poeira. Quando chove, a copa das árvores é o primeiro obstáculo que as gotas de chuva têm de enfrentar até chegarem ao solo. Passando pela copa das árvores mais altas, elas também têm de passar pelas mais baixas, depois pelos arbustos, e por último pelas folhas mortas que estão no chão. Fazê-los imaginar o que aconteceria se a mata não estivesse ali para proteger o solo...

Finalizar destacando a importância da mata ciliar na conservação do rio (da erosão e do assoreamento), pedir para que os visitantes prestem atenção às diferentes espécies de árvores e para procurarem caminhar em silêncio de forma que vejam algum animal, especialmente as aves que são mais facilmente vistas.

\section{PONTO 5 - JEQUITIBÁ}

Nesse ponto, faz-se a dinâmica do abraço na árvore. Os visitantes formam um círculo em torno do Jequitibá abraçando-o. Essa dinâmica tem por finalidade incentivar a percepção da textura do tronco da árvore, a presença ou ausência de líquens e musgos, e principalmente chamar a atenção para o diâmetro da árvore.

Informações sobre o Jequitibá: o Jequitibá é uma árvore típica dessa mata. Ela tem porte alto e crescimento lento. Perguntar qual idade as pessoas acham que ela tem. Dizer que tem mais de 300 anos. Contar que pelo seu porte, é uma árvore que não dá pra plantar na calçada em frente de casa. Pedir para que os visitantes observem a copa da árvore. Perguntar o que eles vêem. Dizer que essa árvore é uma grande “casa”, ela abriga pássaros, insetos e até algumas plantas que se apóiam nela (epífitas, orquídeas e bromélias). Outras plantas servem de alimento para os animais, como o jatobá, que será visto mais adiante. Dizer que as árvores são muito importantes para os animais, afinal 
eles fazem ninhos nelas, comem seus frutos, se abrigam... E os animais também são importantes para as árvores, pois eles dispersam as sementes e fazem a polinização das flores... Alguns animais que podem ser encontrados nessa mata são: anta, capivara, cotia, cachorro e gato do mato, tatu, tucano, periquitos entre outros.

Concluir dizendo que muitos animais dependem da mata para abrigo, reprodução, alimentação e as plantas, por sua vez, dependem dos animais (inclusive insetos) para dispersarem suas sementes e fazer a polinização!

\section{PONTO 6 - FIGUEIRA}

Neste trecho faz-se a dinâmica da trilha cega: de olhos vendados, os visitantes percorrem um trajeto demarcado com um barbante, dentro de um trecho de mata. $\mathrm{O}$ barbante cria um trajeto que une árvores de espessuras e texturas diferentes, com presença ou ausência de liquens, musgos e ainda raízes. A finalidade dessa dinâmica é explorar através do tato essa variedade de indivíduos presentes na mata, e até mesmo a presença da serapilheira, através do som das folhas sendo pisadas. Ao final, todos tiram as vendas e tentam identificar o trajeto que percorreram.

Informações sobre a figueira: a figueira também é uma árvore de grande porte e pode chegar a 20 metros de altura. Seus frutos são bastante apreciados por morcegos e outros animais (retomar as relações entre vegetais e animais). Lembrar os visitantes sobre a importância da mata para conservar o rio e dizer que além da parte aérea das árvores, suas raízes também o protegem do assoreamento... Pedir para que eles imaginem um labirinto de raízes (de diferentes comprimentos e espessuras) debaixo de seus pés. Além das raízes ajudarem a proteger o solo da erosão e do assoreamento, as folhas que caem no solo formam a serapilheira e o banco de sementes - muito importantes na formação do solo (nutrientes). Mostrar que o solo embaixo das folhas é úmido.

Concluir dizendo que a presença da vegetação é muito importante para conservar o solo e perguntar se eles acham que o solo é importante para a vegetação.

JATOBÁ - Madeira utilizada na indústria, fruto é comestível (seres humanos e animais). Resina usada para fabricar vernizes. A casca e a resina são boas para a tosse. 


\section{PONTO 7 - PAU D’ALHO}

Mostrar o Pau d'alho e explicar a razão de ser este o seu nome popular (forte cheiro de alho).

Chamar a atenção dos visitantes para o fato dessa árvore estar morta e em processo de decomposição. Explicar que esse processo é muito importante para a formação do solo. As folhas que caem das árvores formam a camada chamada de serapilheira, que serve de alimento para insetos, animais de porte maior e microorganismos, dentre eles os fungos. Estes atuam na decomposição dessa camada, levando nutrientes para o solo. "A floresta se alimenta dela mesma".

Finalizar esse comentário enfatizando, mais uma vez, que o solo é muito importante para a vegetação.

\section{PONTO 8 - ARATICUM CAGÃO}

Chamar a atenção para o araticum cagão. Explicar o porquê do seu nome: devido ao fato de seus frutos caírem na medida em que amadurecem. O fruto é parecido com a fruta do conde. Dizem também que ele é muito gorduroso e costuma dar dor de barriga.

Perguntar se os visitantes perceberam, durante o percurso, que muitas árvores estão identificadas através de plaquinhas. Comentou-se durante o percurso a finalidade de muitas espécies. Umas dão madeira boa, outras são medicinais, outras servem de alimento para nós e/ou para outros animais. E sobre aquelas que não tem plaquetas, das quais não sabemos a finalidade questioná-los se eles as consideram importantes. Finalizar comentando a respeito da importância da conservação da biodiversidade para manter o equilíbrio dos ecossistemas.

\section{PONTO 9 - FINAL DO TRECHO DE MATA CILIAR}

FINAL DA TRILHA - Neste ponto, faz-se a dinâmica da teia da vida, através da qual os visitantes formam um círculo, e o primeiro diz algo que viu e gostou na trilha. Feito isso, ele joga o barbante (segurando sua ponta) para outra pessoa, que faz o mesmo, e assim sucessivamente, até que se forme uma grande teia de barbante. Para demonstrar como cada elemento é importante, o dano a um desses itens é representado através de 
um puxão no barbante. Outras pessoas também sentirão o impacto desse puxão, mostrando que na natureza todos os elementos estão interligados.

CONCLUSÃO - Na natureza, todos os elementos estão interligados. Se um deles sofrer um prejuízo, outros certamente também sofrerão. Assim, a conservação da biodiversidade é muito importante para a manutenção do equilíbrio dos ecossistemas. 


\section{APÊNDICE G - Questionário de avaliação do curso de formação de monitores ambientais \\ 20 e 21 de agosto de 2004 - São José do Rio Pardo}

1- O curso atingiu suas expectativas?
( ) $\operatorname{sim}$
( ) não
( ) mais ou menos
Comente

2- Quanto ao conteúdo, você avalia o curso como:
( ) insuficiente
( ) regular
( ) bom
( ) ótimo

Comente

3- Existem conteúdos que você considera importantes e que não foram abordados no curso?

4- Quanto às metodologias utilizadas, você avalia o curso como:
( ) insuficiente
( ) regular
( ) bom
( ) ótimo

Comente

5- Quanto à duração, você avalia o curso como:
( ) insuficiente
( ) regular
( ) bom
( ) ótimo

Comente

4 - Quais foram as contribuições que o curso proporcionou a você, em nível:

Pessoal

Profissional (conhecimentos técnicos) 
5- Este curso traz alguma nova possibilidade para você?
( ) $\operatorname{sim}$
( ) não
( ) depende

Comente

Qual ? ( ) possibilidade de nova atividade profissional

( ) possibilidade de aprimoramento na minha atividade profissional

( ) possibilidade de multiplicar o que aprendi aqui

( ) outras. Quais?

6 - O que você mais gostou no curso?

7 - O que você menos gostou no curso?

8- Sugestões para melhorar o curso: 


\section{APÊNDICE H - Roteiro de questões para a avaliação pré -trilha com os estudantes de ensino fundamental.}

1- Bacia Hidrográfica é um conjunto de sistemas aquáticos interligados, tanto de águas subterrâneas como de águas superficiais (córregos, rios, lagos, represas). Existe uma bacia hidrográfica na região de São José do Rio Pardo? Vocês se lembram o nome de alguns rios, córregos, lagoas ou represas da cidade? Quais?

2- Vamos supor que um desses rios tenha sido contaminado com produtos agrotóxicos. Sabendo que esse rio pertence a uma bacia hidrográfica, vocês diriam que os outros rios da região podem ser prejudicados? E de outros estados do Brasil? E de outros países? Expliquem.

3- Digam quais alternativas abaixo podem sofrer prejuízos com a contaminação do rio e expliquem. Peixes? Algas? Sapos? Aves? Vegetação ao lado do rio? Ser humano? Bois que pastam próximo ao rio? Hortas próximas ao rio? Solo?

4- O que vocês sabem sobre o rio Pardo? O que ele significa para a cidade? Por quê? Como está a qualidade das suas águas? Tem peixe (muito ou pouco)? As pessoas nadam nele? O que nós podemos ou devemos fazer em relação a ele?

5- Mata ciliar ou mata galeria é um tipo de formação vegetal que acompanha os rios. Possui árvores de grande porte e também plantas epífitas (que vivem sobre outros vegetais ou pedras), além de musgos, porque há uma elevada umidade do ar e do solo. Vocês poderiam dizer qual é a importância da mata ciliar para o ambiente?

6- Vocês já estiveram em uma área de mata ciliar antes? Onde? Vocês acham que estava bem conservada? Tinha animais? Grandes ou pequenos? Como era o clima dentro dela? Era igual ou diferente de outros ambientes (naturais, urbanos)? Como foi? O que sentiram? Gostariam de voltar?

7- Vocês já ouviram falar na fazenda Tubaca? O que ouviram falar? Já estiveram lá? Se sim, como foi? Se não, gostariam de conhecer esse local? Por quê?

8- O que vocês acham que vão ver lá? O que gostariam de ver? O que não gostariam de ver lá?

9- Tentem imaginar uma plantação de cana e uma mata ciliar e comparem essas duas áreas quanto à diversidade de animais e vegetais. Em qual delas há maior variedade (tipos diferentes) de animais e vegetais?

10- A cana é utilizada pelas usinas para a obtenção de açúcar e álcool. Se a população cresce e o consumo dos produtos derivados da cana também, como vocês imaginam que poderia haver um crescimento da área plantada com cana e ao mesmo tempo conservação das matas nativas?

11- O lixo produzido diariamente nas escolas, casas, hospitais, escritórios, etc. é de responsabilidade da Prefeitura Municipal. Assim, é dever do prefeito colocar o 
lixo em um local onde cause os mínimos prejuízos para a população e para o meio ambiente. Imaginem que vocês fossem o prefeito. Que cuidados teriam para escolher esse local? 


\section{APÊNDICE I - Roteiro de questões para a avaliação pós-trilha com os estudantes de ensino fundamental.}

1 - Como vocês resumiriam o que aprendeu na visita à trilha da Tubaca?

2 - O que vocês aprenderam de novo? Vocês tiveram a oportunidade de ensinar algo que já sabiam antes?

3 - Vocês sabem o nome de alguns rios, córregos, lagos ou represas que estão próximos a sua cidade? Quais são? Alguns deles fazem parte da bacia hidrográfica do rio Pardo? Quais?

4 - Durante a visita a trilha da Tubaca, vocês conheceram um trecho da mata ciliar do rio Pardo. O que aconteceria com os seres vivos dessa área se houvesse um desmatamento dessa região? E o que aconteceria com o rio Pardo?

5 - Como vocês acham que devia ser esse ambiente no tempo dos nossos pais, avós, bisavós? O que vocês acham que vai acontecer com esses pequenos trechos de mata? O que nós podemos ou devemos fazer em relação a eles?

6 - Considerando a utilização que o ser humano faz da cana, seria bom plantar mais cana no lugar das áreas de matas nativas? Expliquem.

7 - A cana de açúcar é uma planta exótica, ou seja, não é natural do Brasil. O que acontece com a diversidade de plantas e animais quando se substituem áreas de matas nativas por plantação de cana?

8 - O que vocês sabem sobre o rio Pardo? O que ele significa para a cidade? Por quê? Como está a qualidade das suas águas? Tem peixe (muito ou pouco)? As pessoas nadam nele? O que nós podemos ou devemos fazer em relação a ele?

9 - Aqui em São José ainda não existe tratamento de esgoto, ou seja, todo o esgoto que sai das nossas casas, hospitais, escolas, etc. (água com fezes, bactérias, resíduos de detergentes e outros materiais) é despejado no rio Pardo. Sabendo disso, respondam se isso pode causar prejuízos para os rios da bacia do rio Pardo. E para outros rios do estado de São Paulo? E de outros estados?

10 - Suponham que cada um de vocês é o prefeito de São José do Rio Pardo e precisam arrumar um local para colocar todo o lixo que é produzido na cidade. $\mathrm{O}$ único local disponível é um terreno afastado da cidade e próximo a nascente de um rio. O que vocês fariam?

11 - O que vocês acharam da extensão da trilha? Como vocês se sentiram após o percurso?

12 - O que vocês acharam do número de paradas?

13 - Que palavra (adjetivo) vocês usariam para expressar o que acharam da trilha? 
14 - O que vocês acharam do guia? Houve oportunidade para que vocês expressassem suas dúvidas e curiosidades? Elas foram resolvidas? Vocês ainda se lembram delas? Quais foram?

15 - O que vocês mais gostaram nesta atividade?

16 - O que vocês menos gostaram nesta atividade?

17 - O que vocês sugerem para melhorar esta atividade?

18 - Vocês fariam a trilha novamente? Levariam alguém com vocês? Quem?

19 - Dêem uma nota de 0 a 10 para a trilha da Tubaca. 


\section{APÊNDICE J - Roteiro de questões para a avaliação da atividade de visita à trilha com os participantes.}

1- Como vocês avaliam a visita das crianças a trilha (pontos positivos e negativos)?

2 - Vocês notaram alguma diferença em relação às turmas piloto e as avaliadas?

3 - O que facilitou e/ou dificultou as visitas?

4 - Como vocês avaliam o trabalho dos monitores ambientais? O que ajudou? O que dificultou?

5 - Qual sua opinião sobre as dinâmicas realizadas na trilha?

6 - O que pode ser melhorado? 


\section{APÊNDICE K - Roteiro de questões para a avaliação do processo da pesquisa com os participantes.}

1 - As suas expectativas em relação ao projeto foram atingidas?

2 - Como vocês avaliam a sua participação no processo do trabalho como um todo?

3 - O que dificultou e ou facilitou essa participação?

4 - O trabalho envolveu pessoas com diferentes opiniões? Como foi essa experiência?

5 - O trabalho provocou alguma mudança no pensamento que vocês tinham sobre a realidade do município?

6 - Quais os pontos positivos deste trabalho?

7 - Quais os pontos negativos deste trabalho?

8 - O que pode ser melhorado em futuros trabalhos participativos?

9 - Foram retiradas propostas concretas? Vão ser implementadas? Como está seu andamento?

10 - O trabalho teve algum desdobramento em outros projetos? (de melhora da qualidade ambiental do município? De educação ambiental? Qual?) 
ANEXO A - Carta de autorização do projeto elaborada pela delegada regional de ensino e enviada às escolas da rede estadual

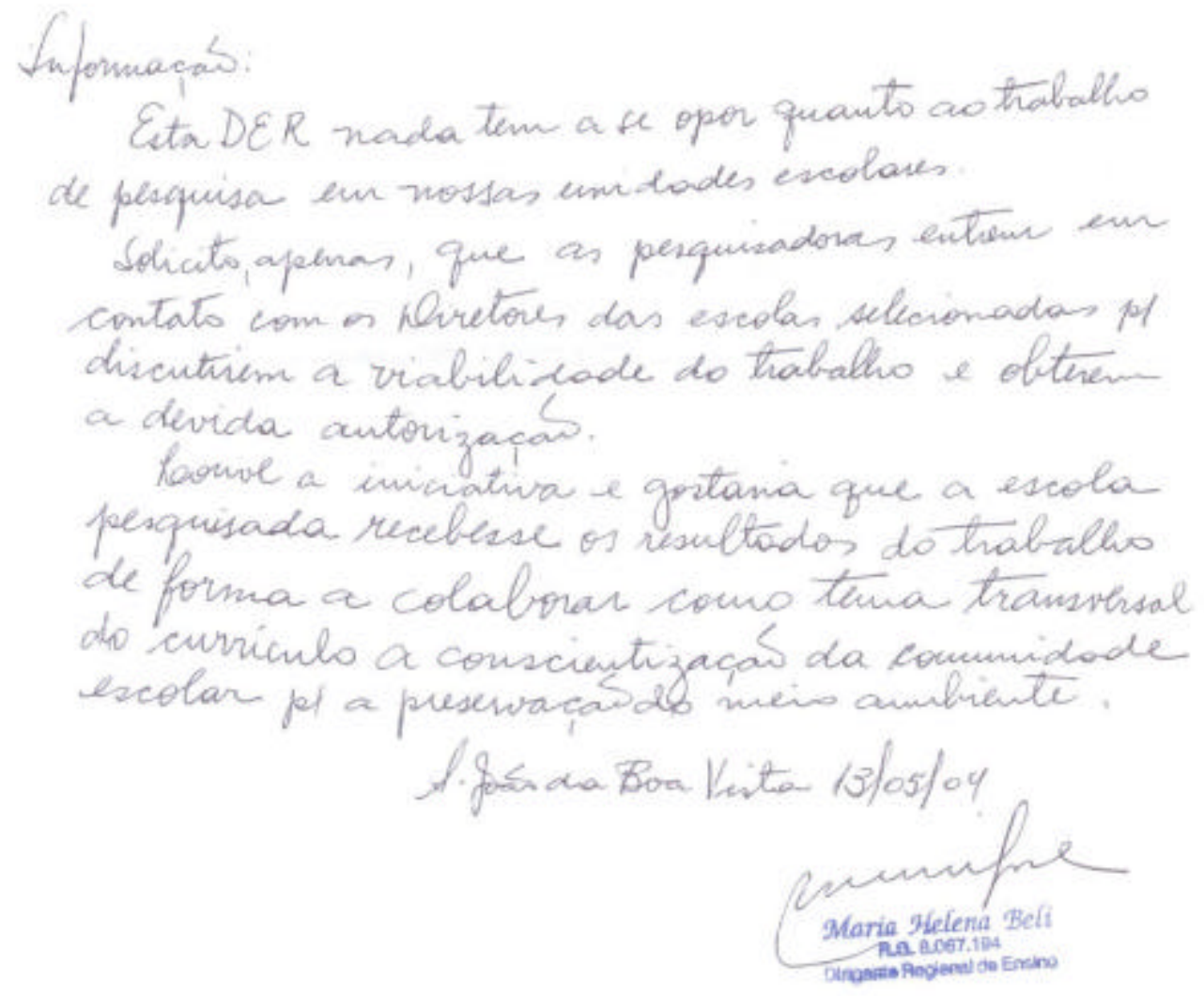


ANEXO B - Reportagens sobre o projeto publicadas em jornais locais.

26 de junho de 2004 - GAZETA DORIO PARDO - A -9

\section{Projeto arrasta-pé vai começar}

Alvaro Ribeiro de Oliveira Netto

A Secretaria de Turismo. com a participaçio das biólogas Maria Alice, Ariane . Graça e Rodrigo Polachini. da Rastro Esporte Aventu$\mathrm{ra}$, dá inicio neste domingo ao projeto arrasta-pé, com c reconhecimento da "trilha dos carrapatos". O percuro será feito a pé a partir do pontilhão no final da alameda dos Ipés, passando pela fazenda Tubaca, loteamento Santa Lourdes até a cachoeira da Santa Helena, a unica localizada cm dominios municipais. A visita técnica, como é chamada esta primeira incursão, tem como proposta o reconhecimento da trilha, seus perigos, suas vantagens e suas belezas para em seguida começar um trabalho junto as escolas e promover passeios que terāo como finalidade principal a conscientização dos estudantes jovens sobre as vantagens da preservação ambiental. As biólogas estẫo trabalhando junto a Secretaria há algum tempo e o primeiro trabalho for na fazenda Santa Teresa. Na terçafeira, dia 29 uma reunião na Câmnra Municipal vai definir o rumo do arrasta-pé.

\section{Está decidido}

A Associação de Rio-pardenses Amigos ARA, confirmou no começo da Semana a participaçẩo na Semana Euclidiana deste ano, homenageando a conferencista Celia Mariana Franchi Fernandes da Silva. As solenidades serão no Buffet Raddi.

Em andamento

Na terca-feira estive com oprofessor Ary Menardi, diretor da Faculdade de Filosofia para expor o plano $\mathrm{cm}$ andamento para se criar meThores condiçōes de funcionamento da Semana Euchdrana. Ary Menardi informou que o proicto pedagógico da faculdade solicitando $\mathrm{cm}$ préstimo junto ao BNDES para a construção do campus csta pronto e que seria enviado a Brasilia até sexta-feira (ontem). A intenção C liberar o predio da antiga FEPASA para atividades culturais, se possivel ampliando o curso de Desenho e Arte da Faculdade. Coloquei-me a disposiçấo da congregaçầo da escola para explicar o plano. acalar sugestĩo ou assimilar novas idéias. A intenção e. melhorar as condiçes culturais de Salo José do Rio Pardo. Esta proposta foi discutida com o prefeito João Santurbano em reuniâo dia 14 com a presença do presidente do Conselho Euclidiano. professor Marcio José Lauria

Cabo Verde volta à SE-04

$O$ instrutor da fanfarra de Cabo Verde (Vaguinho) confirmou no final desta semana a participação das fanfarras de Cabo Verde e Caconde no desfile de abertura da Semana Euclidiana. Como acontece todos os anos o desfile está despertando grande interesse entre escolas c instituição. Nesta semana sera realizada outra reunião para acertar os últimos detalhes. As meninas de Cabo Verde ja estiveram em São Jose do Rio Pardo em anos anteriores e são reconhecidas como uma atraçåo

\section{Turismo}

A proposta de se envolver a Semani Euclidiana com o Tu.

fismo devera tomar impulso este ano com a criaçào de uma Oficina para a formacâo de guias turísticos. As conversaçōes estão no começo mas, no final desta semana, tudo estará resolvido. O publice alvo sera a guarda-mirim. A falta de guias turisticos o um dos maiores problemas da Secretaria A oficina sera ministrada por especialistas na árca.

\section{O julgamento de}

Conselheiro

Um grupo de 15 alunos do Externato Santa Terezinha. de Araraquara virá a São lose do Rio Pardo fazer o julgarnento de Antonio Conselheiro. A sessio será pública e os estudantes (todos do ensino medio) se dividirăo $\mathrm{cm} 4$ advogados, 4 promotores e 7 jurados. Após ataques e defesas, a absolviçẩo ou condenaçâo será decidida por um juiz de direito especialmente convidado para presidir o juri. A sesslo deve durar de uma hora e meia a duas horas e se trata de uma atividade inédita na Scmana euclidiana. $\mathrm{O}$ local do Juri ainda năo foi definido.

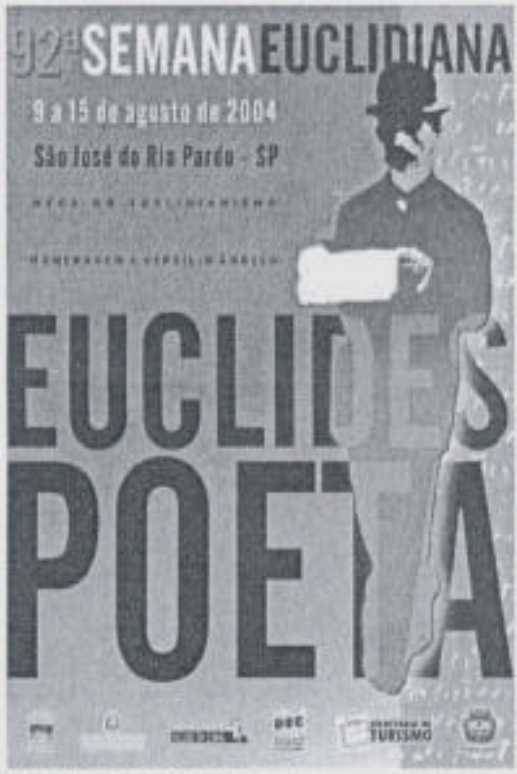

O CARTAZ da SE 2004, desenvolvido pela Divulgue, ilustra o tema central deste ano: Euclides Poeta. A imagem mostra um Euclides de chapéu coco, como um cidadilo comum lendo jornal, em rua da cidade. $A$ foto foi publicada no jornal Dom Casmurro, de 1946. 


\section{Sarau repete sucesso anterior}

\section{Alvaro Ribeiro de} Oliveira Neto

Com a participação de 12 alunos das Escolas Laudelina de Oliveira Pourrat, Joẫo Gabriel Ribeiro e Cándido Rodrigues, o sarau cultural realizado domingo passado foi novamente um sucesso. A diretora do Jos̄o Gibriel Ribeiro, professora Silvia Helena Dalbom Barbosa co professor Benedito Tadeu Euzébio do Cândido, alćm de pais de alunos prestigiaram e aplaudiram o evento A musica ficou por conta do Grupo Sol Laranja, integrado por Nenê Morgante, Euripedes e Tio Dê, que apresentou didaticamente músicas autorais, com temas relacionados a preservaçä́o ambicatal, uso de drogas, entre outros. O texto dos alunos tamberm se referiu quase sempre a questỏes relacionadas à exclusåo e à violência. O sarau cultural que pretendia ser estimulo à leitura e a produçăo de textos tem, agora, novo caráter: o de apoiar estas mesmas iniciativas que, ao que tudo indica, já vem sendo adotada pelas escolas.

O Museu Rio-pardense Arsênio Frigo esta com uma programaçäo cultural bastante interessante para o mês de julho. Todas as segundas-feiras serão realizados enconntros com artistas o teóricos locais que vắo fazer depoimentos sobre suas atividades. No dia 5 (segunda-feira) o Ciclo seráa aberto com Benê Trevisan, que c o coordenador e curador cias palestras; no dia 12, Maria Celina Agliussi, cantora e artesâ, dia 19, Marcelo Rontangnholi, ator de teatro e especialista cm Arte e Cultura Contemporânea e, no encerramento. José Márcio Molfi falará sobre sua experiência no mercado de arte no pais. Ainda no mes de julho, no dia 18 (domingo) haverá o recital como violonista Marcelo Carvalho e para $1^{\circ}$ de agosto (domingo) uma camerata com oito violonistas vai apresentar um repertorio mostrando a evoluçẫo da música erudita. Para a Semana Euclidiana o Museu está preparando uma exposiçấo de maquetes de prédios rio-pardenses obras do acervo. Nosso auditório é pequeno mas tem estado lotado e as atividades têm sido clogiadas.

COMTUR participa do desfile da SE-04

Uma aprescritaçà̃o bastante original no desfile da Semana Euclidiana e o que promete o Conselho Municipal de Turismo COMTUR. As atividades tém apoio dos Departamentos de Fomento ao Turismo (Elisa Mori) e de Infracstrutura (Alfredo) é a proposta e trabalhar a Semanis Euclidiana tambem como produto turistico. Esta deci. são é resultado das oficinas do projeto de Desenvolvimento do Turismo Receptivo PDTR, que tem apoio do SEBRAE

\section{Reservas}

Alguns hotéis de São José do Rio Pardo estão recebendo reservas para a Semana Euclidiana Isto fez com que agilizássemos as reservas dos professores para evitar riscos. Segundo tudo indica, havera ocupaçîo total das vagas
Esportes na SE-04

$\mathrm{Na}$ terça-feira conversei com o Rina (Departamento de Esportes do DEC) e com o Dovil (professor de Kara. tê) sobre o esporte na Semana Euclidiana, A programa̧̧ăo proposta d vasta, inclui praticamente todas as escolas do municipio e envolve aproximadamente 2.000 alunos-atletas. Serão disputados 16 modalidades esportivas com jogos realizados no Ginásio de Esportes, Pista de Atletismo "Palmiro Petroce. Ili" e quadra do Grêmio Nestlé, O Rio Pardo Futebol Clube e a Universidade Santana também participarão das atividades esportivas. O Rina me disse que os Jogos Olimpicos da Semana Euclidiana - J.O.S.E. estão crescendo e que este ano terão caráter regional. E esperada a participaçâo do Rio Pardo com um jogo-demonstração de bascuete e o projeto Shalon (José Ricardo) estará com a canoagem no dia 15 (encerramento da Semana), no $\mathrm{Re}$ canto Euclidiano.

\section{Meio Ambiente}

As biologas Ariane e Graça da Universidade Federal Săo Carlos apresentaram na terça-feira o projeto para a definição de uma trilha que terá como proposta a educação ambiental de estudantes da $6^{2}$ série de todos as escolas. O projeto despertou interesse, A trilha escolhida $e$ a da Fazenda Tubaca e o proprictário (Eduardo Roxo Nobre), presente à reuniāo, concordou e estimulou o projeto. Além dos aspectos educacionais a trilha terá grande interesse turístico 


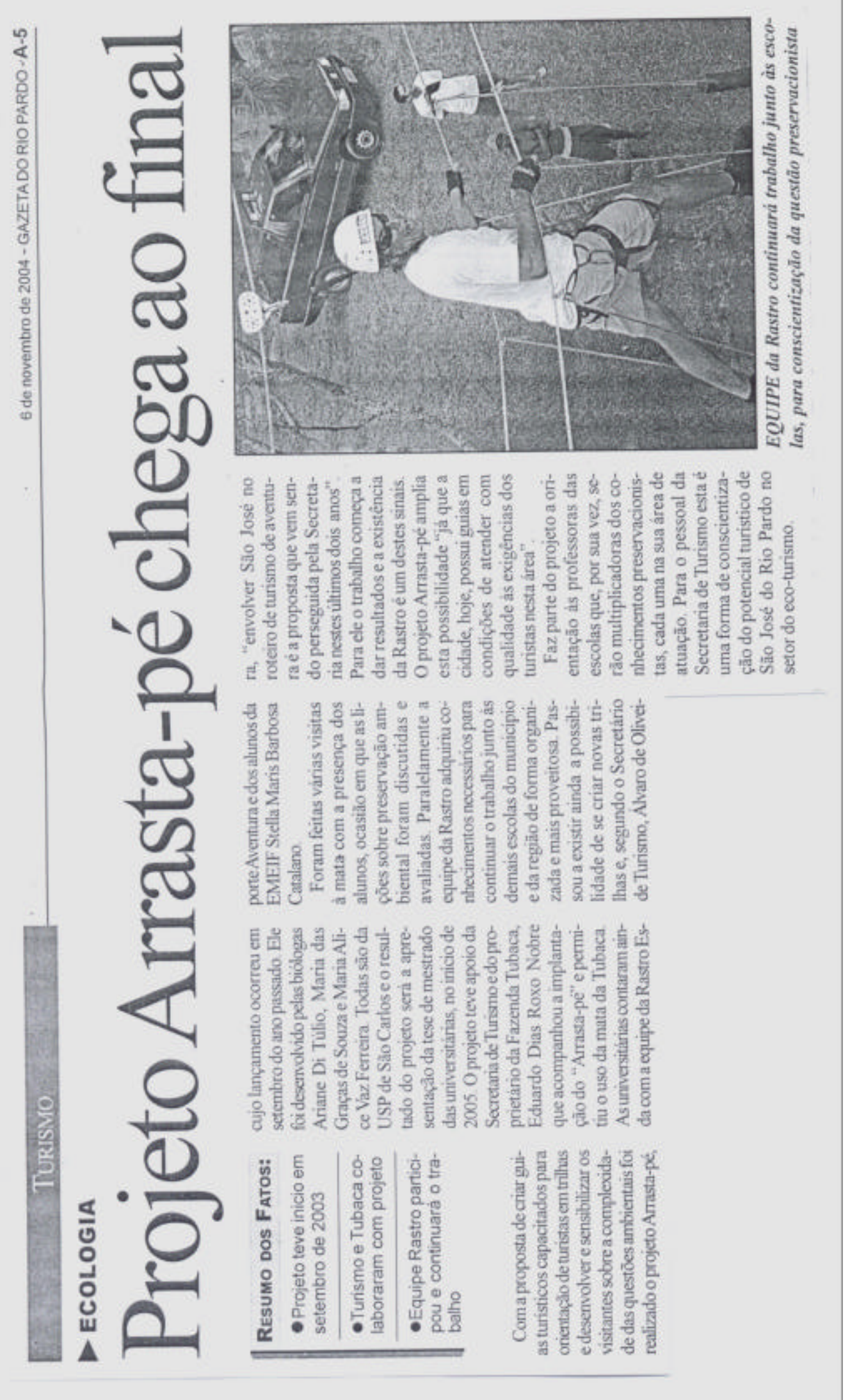




\section{Programa Escola da Família realiza passeio na Mata da Tubaca}

O Programa Escola da Família da E.E. "Profo Jorge Luiz Abichabki" juntamente com a Equipe Rastro Aventura, realizou no último sábado (23) o I Passeio Ecológico na Mata da Tubaca.

Durante o passeio pela trilha dentro da mata, os alunos tiveram aula sobre ecologia ministrado pelo instrutor Rodrigo Polachini, que falou sobre a importância da mata ciliar. O grupo conheceu vários bichos e diversas espécies de árvores. Encerrando o passeio foi realizada uma brincadeira destacando a importância da não poluição dos rios e da não devastação das matas.

Participaram do passeio aproximadamente 50 pessoas, dentre as quais Daniel Ramos Maziero (educador profissional); educadores universitários (Mateus Charles Rodrigues, Priscila Madalena da Silva, Simoni da Silva, Yan Amaral Ohwada, Telma Aparecida da Silva Neves); voluntários (Lígia e Juliana), instrutores da Equipe Rastro (Rodrigo e Alex), alunos e pais.

O Projeto Escola da Família da EE "Prof" Jorge Luiz Abichabki" conta com o patrocínio Auto Mecânica Landinho, Papelaria L\&S e Perillo\&Irmãos. 


\section{ANEXO C - Indicadores de participação \\ (STOREY, 2003)}

\section{Indicadores do nível de participação individual}

\begin{tabular}{|l|l|l|l|l|l|l|}
\hline \multicolumn{1}{|c|}{$\mathrm{N}^{\mathrm{o}}$} & Desinteresse & Atenção & \multirow{2}{*}{ Rejeição } & \multicolumn{3}{|c|}{ Participação } \\
\cline { 5 - 7 } & & & & I & II & III \\
\hline 1 & & & & & & \\
\hline 2 & & & & & & \\
\hline 3 & & & & & & \\
\hline 5 & & & & & & \\
\hline 6 & & & & & & \\
\hline 7 & & & & & & \\
\hline 8 & & & & & & \\
\hline 9 & & & & & & \\
\hline
\end{tabular}

Desinteresse: a pessoa não participa das atividades nem comunica a sua opinião;

Não presta atenção: a pessoa somente conversa com as pessoas ao seu lado;

Rejeição Passiva: a pessoa apresenta negatividade sobre as atividades e o processo em geral;

Participação I: a pessoa participa das atividades;

Participação II: a pessoa faz perguntas sobre as atividades ou sobre os assuntos;

Participação III: a pessoa faz perguntas e coloca suas opiniões sobre as atividades e os assuntos.

\section{Indicadores do grau de interação do grupo}

\begin{tabular}{|l|l|l|l|l|l|l|l|}
\hline \multicolumn{1}{|c|}{$\mathrm{N}^{\mathrm{o}}$} & Solitária & Superior & Grupinho & Rejeição & \multicolumn{3}{|c|}{ Integração } \\
\hline & & & & & I & II & III \\
\hline 1 & & & & & & & \\
\hline 2 & & & & & & & \\
\hline 3 & & & & & & & \\
\hline 4 & & & & & & & \\
\hline 5 & & & & & & & \\
\hline 6 & & & & & & & \\
\hline 7 & & & & & & & \\
\hline 8 & & & & & & & \\
\hline 9 & & & & & & & \\
\hline
\end{tabular}

Solitária: a pessoa não interage com as outras e parece não estar com vontade de participar das atividades;

Superior: a pessoa mostra que é superior às outras do grupo;

Grupinho: pessoas formam um pequeno grupo que exclui outras;

Rejeição Passiva: a pessoa não ajuda as outras;

Integração I: a pessoa possui interesse, mas não se manifesta por timidez ou dificuldade em se expressar;

Integração II: a pessoa interage com a maioria do grupo;

Integração III: a pessoa interage espontaneamente com todos, chegando a ser solidária. 


\section{ANEXO D - Fotos}

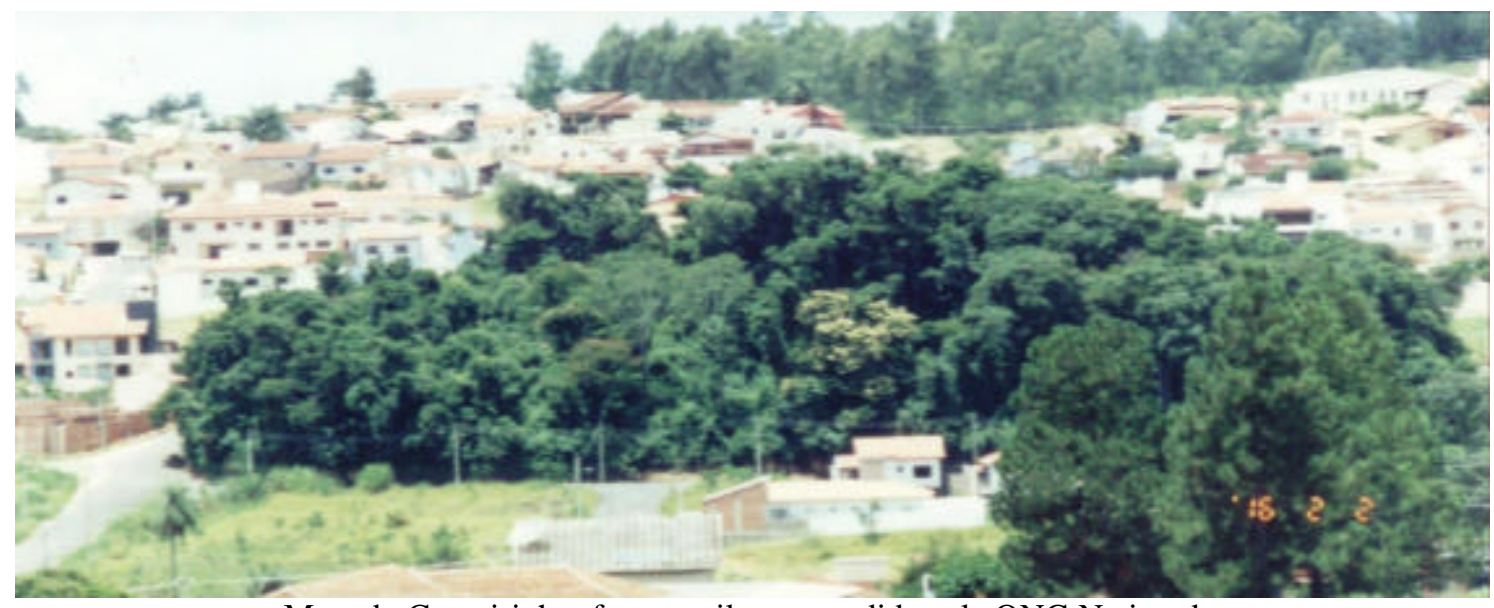

Mata do Carneirinho: foto gentilmente cedida pela ONG Nativerde.

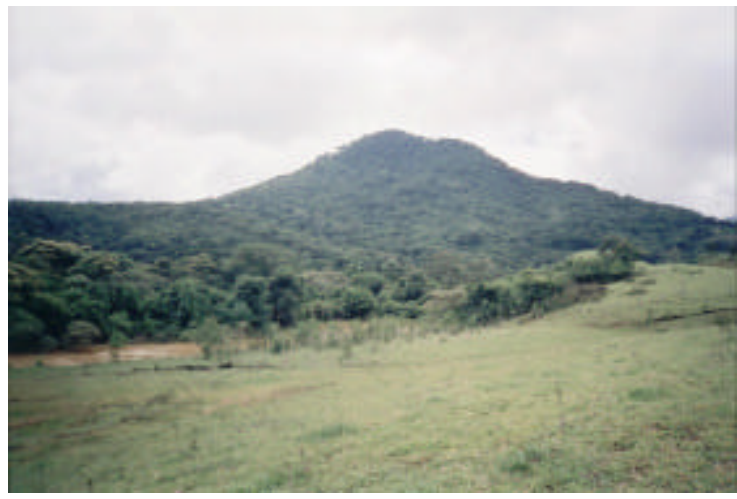

Vista da Fazenda Santa Teresa

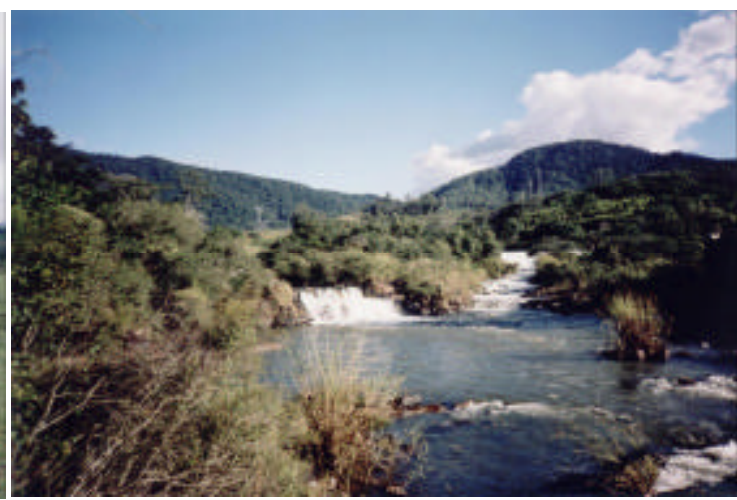

Vista da Fazenda Fortaleza

FIGURA 7 - Locais visitados com a finalidade de implantação da trilha interpretativa. 


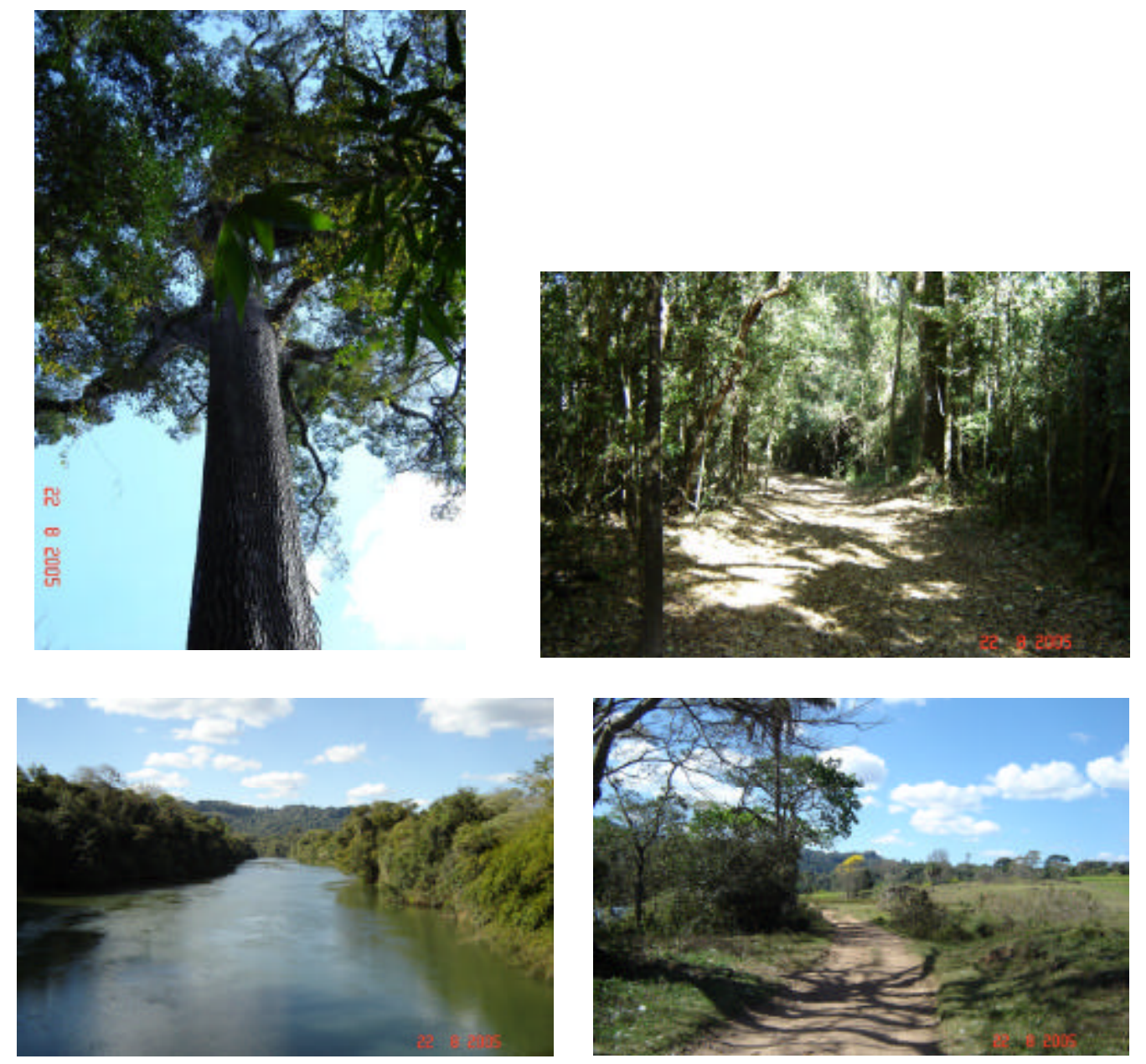

FIGURA 8 - Fazenda Tubaca: local escolhido para a implantação da trilha interpretativa. 


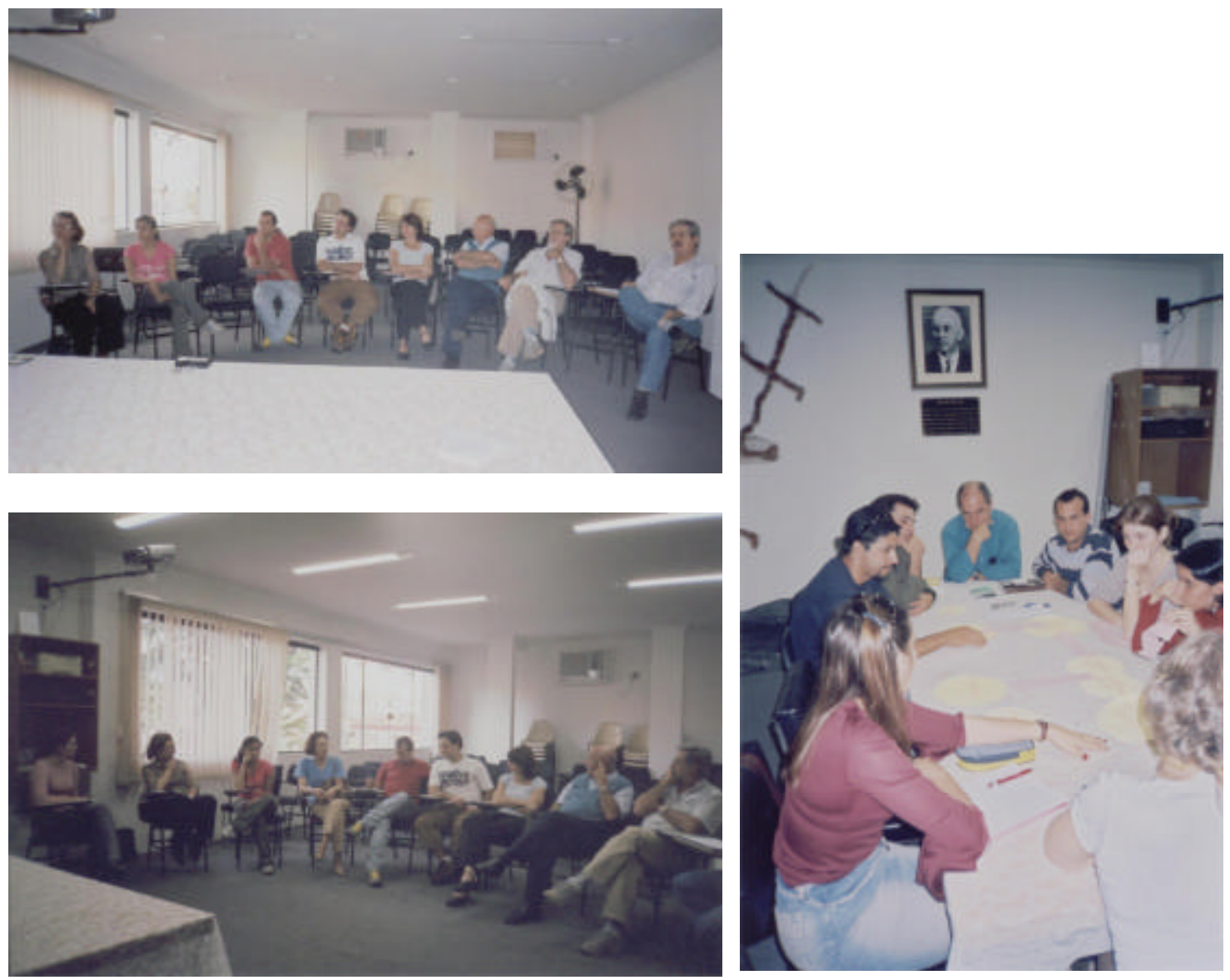

FIGURA 9 - Primeira reunião realizada com os participantes de São José do Rio Pardo.
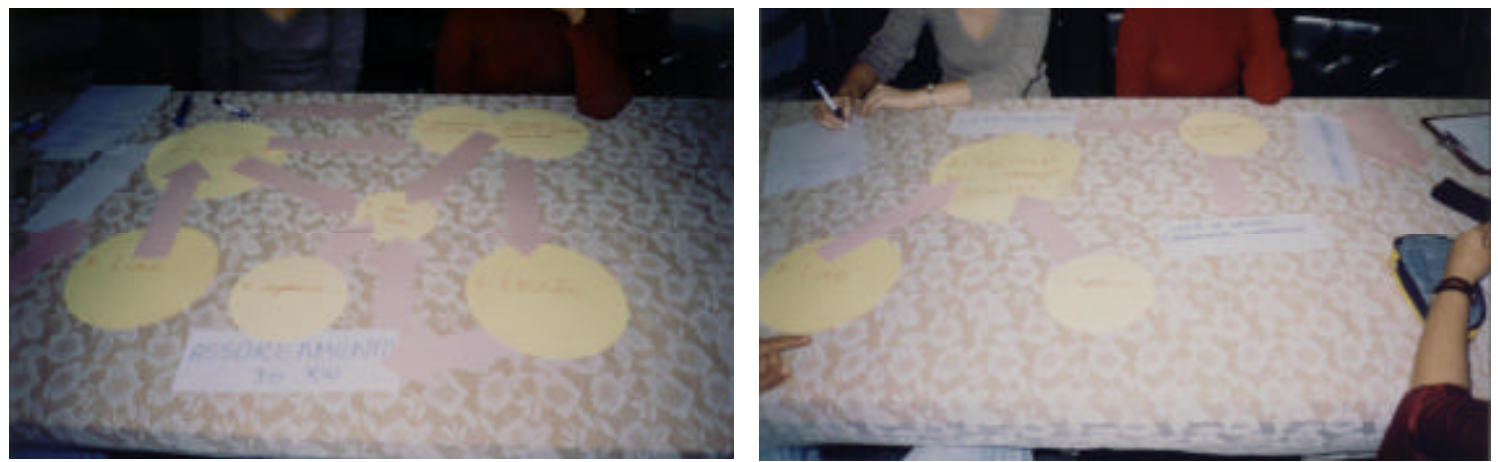

FIGURA 10 - Diagramas construídos pelos participantes referentes aos problemas ambientais locais. 


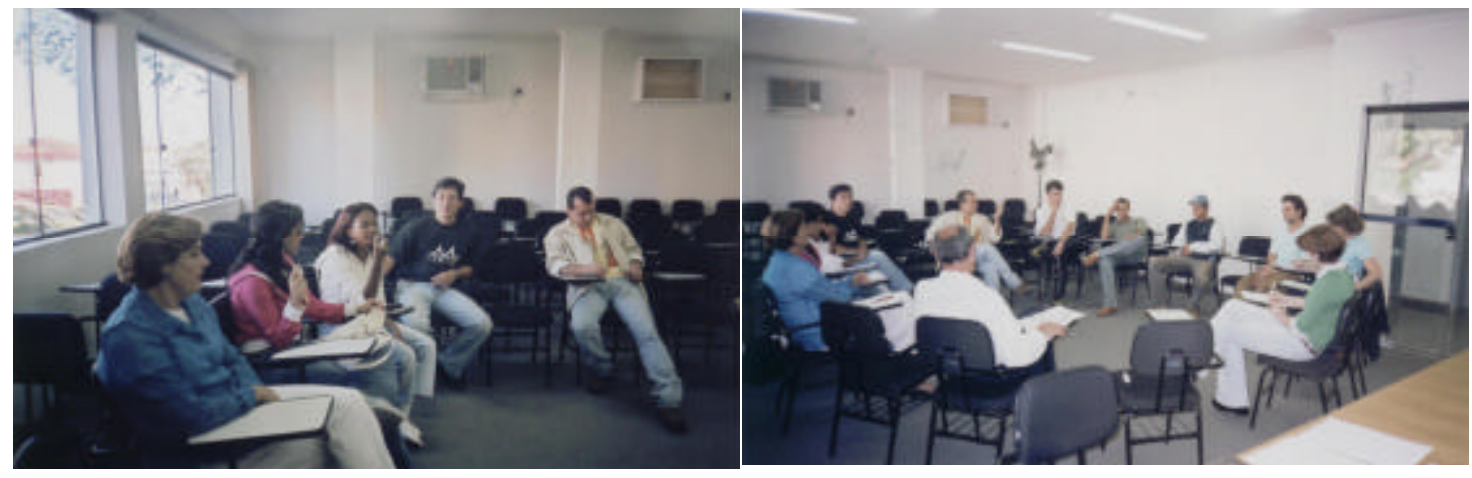

FIGURA 11 - Discussões realizadas durante o curso de formação de monitores ambientais.
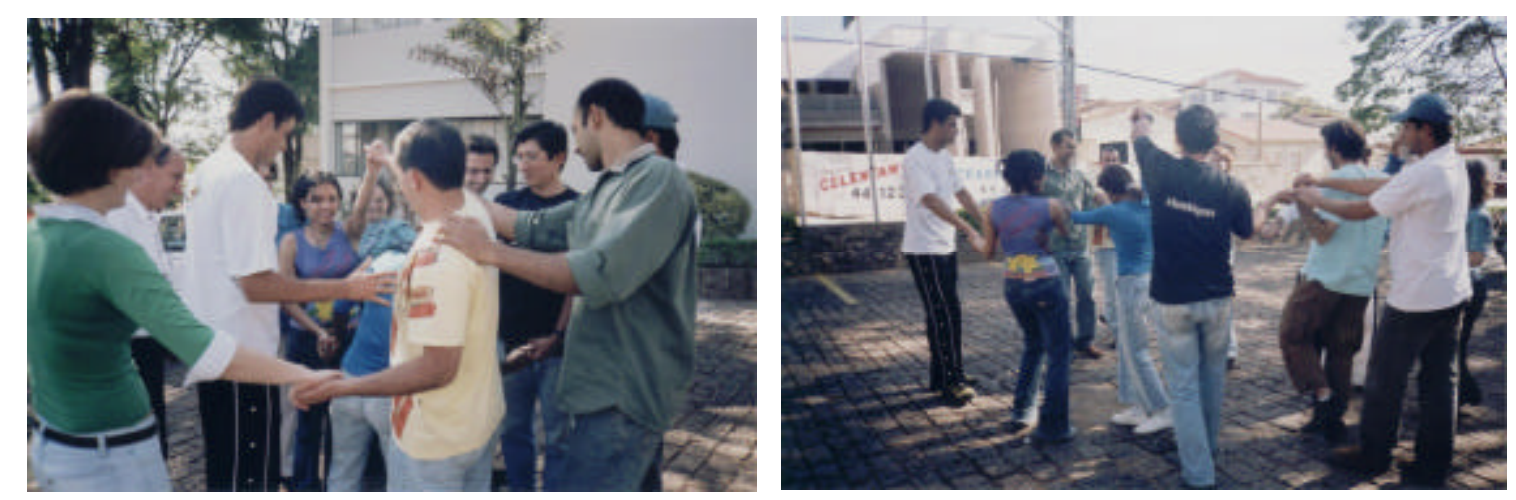

FIGURA 12 - Dinâmicas de grupo realizadas durante o curso de formação de monitores ambientais. 


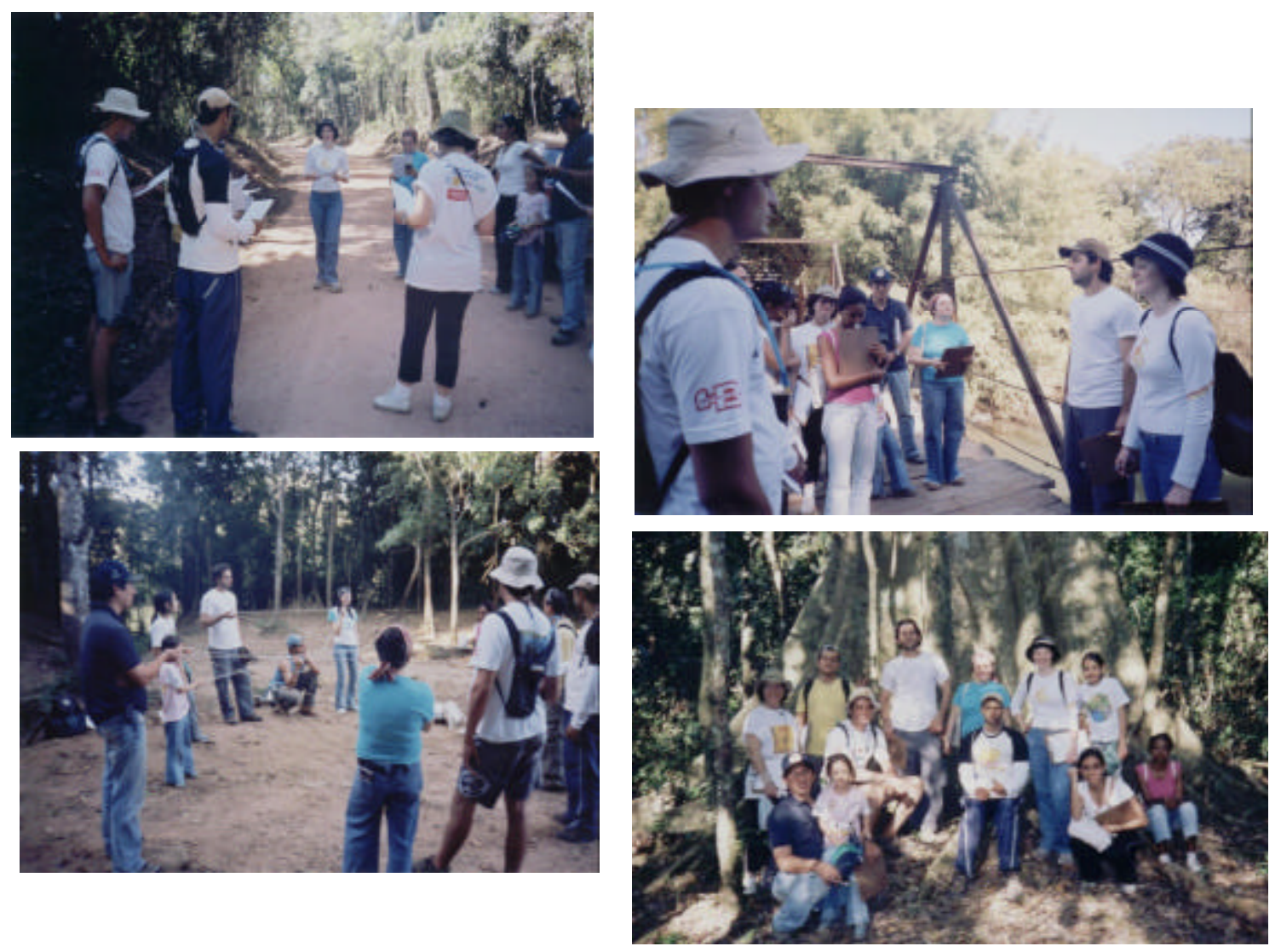

FIGURA 13 - Visita à trilha da Tubaca com os participantes do curso de formação de monitores ambientais. 


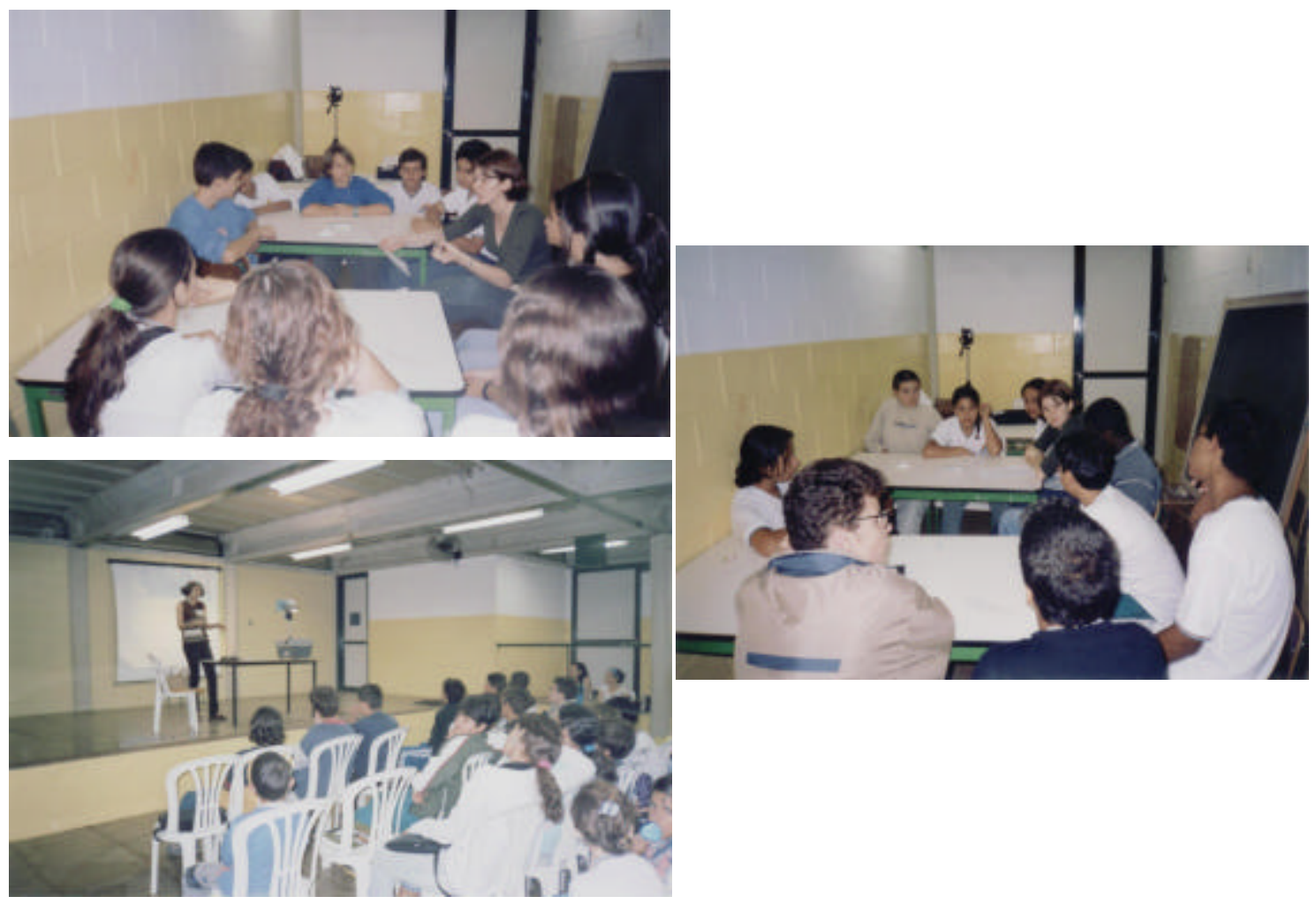

FIGURA 14 - Grupos focais e palestra, realizados com os estudantes de ensino fundamental antes da visita à trilha da Tubaca. 


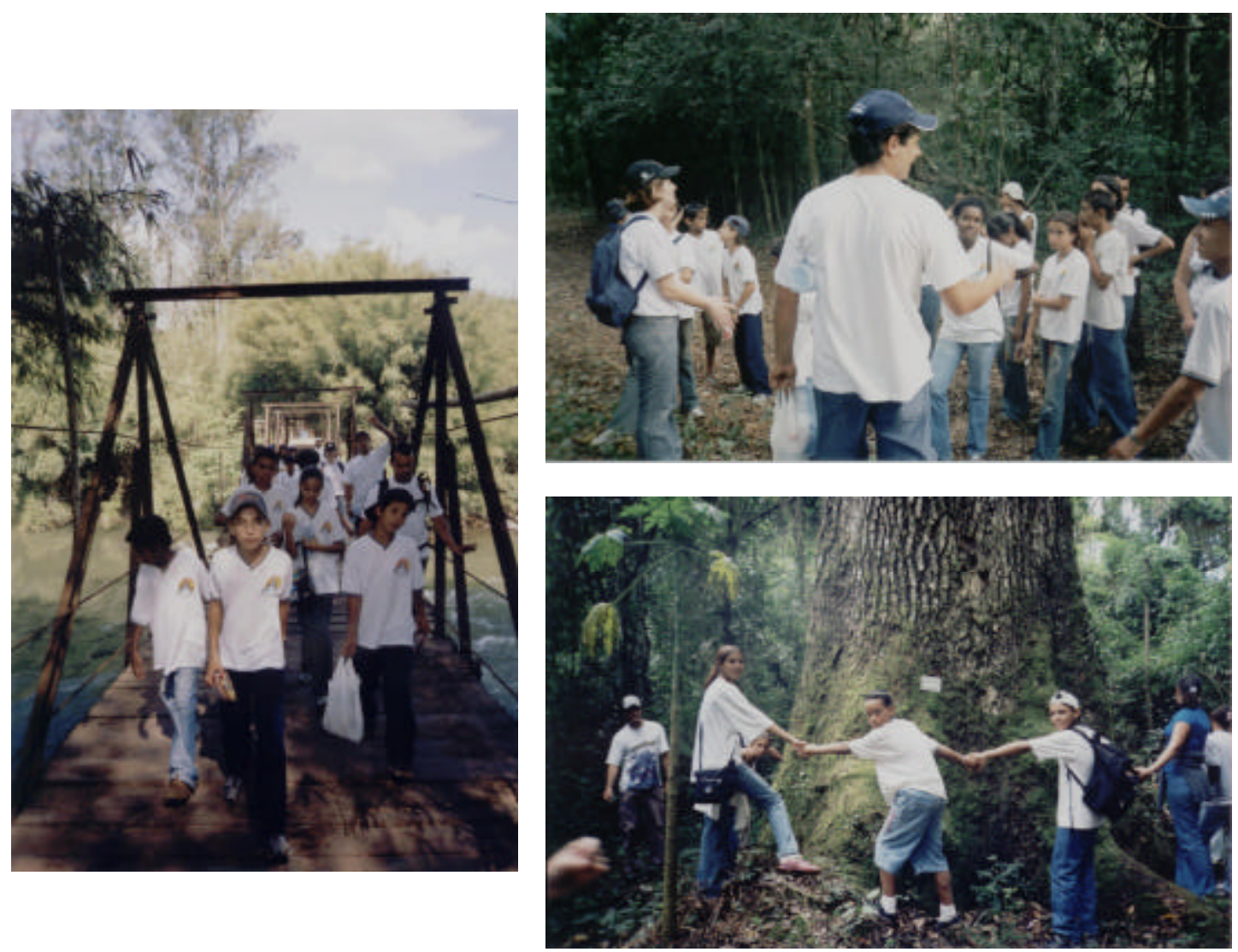

FIGURA 15 - Cenas da visita à trilha da Tubaca pelos estudantes de ensino fundamental. 


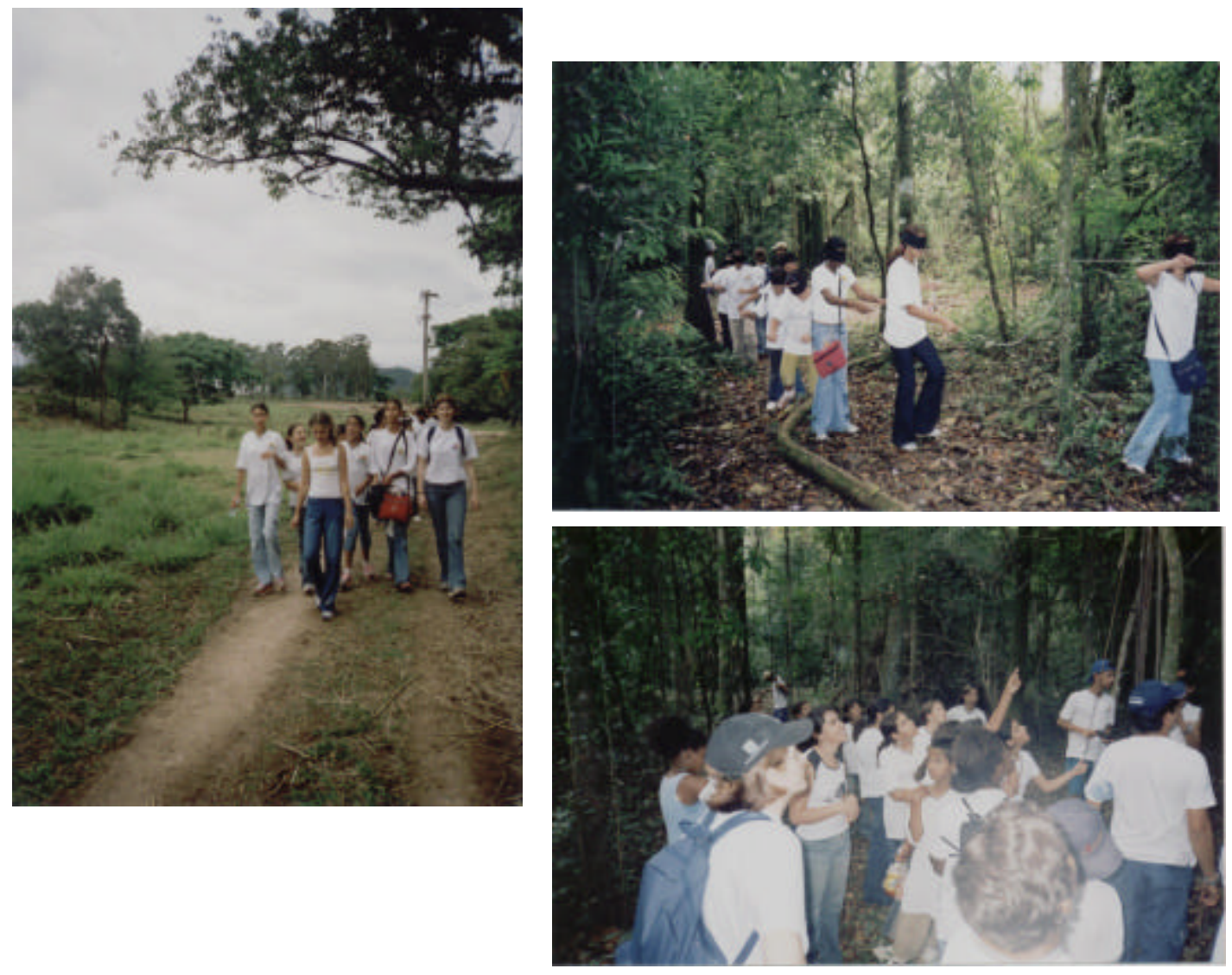

FIGURA 16 - Estudantes de ensino fundamental em visita à trilha da Tubaca. 


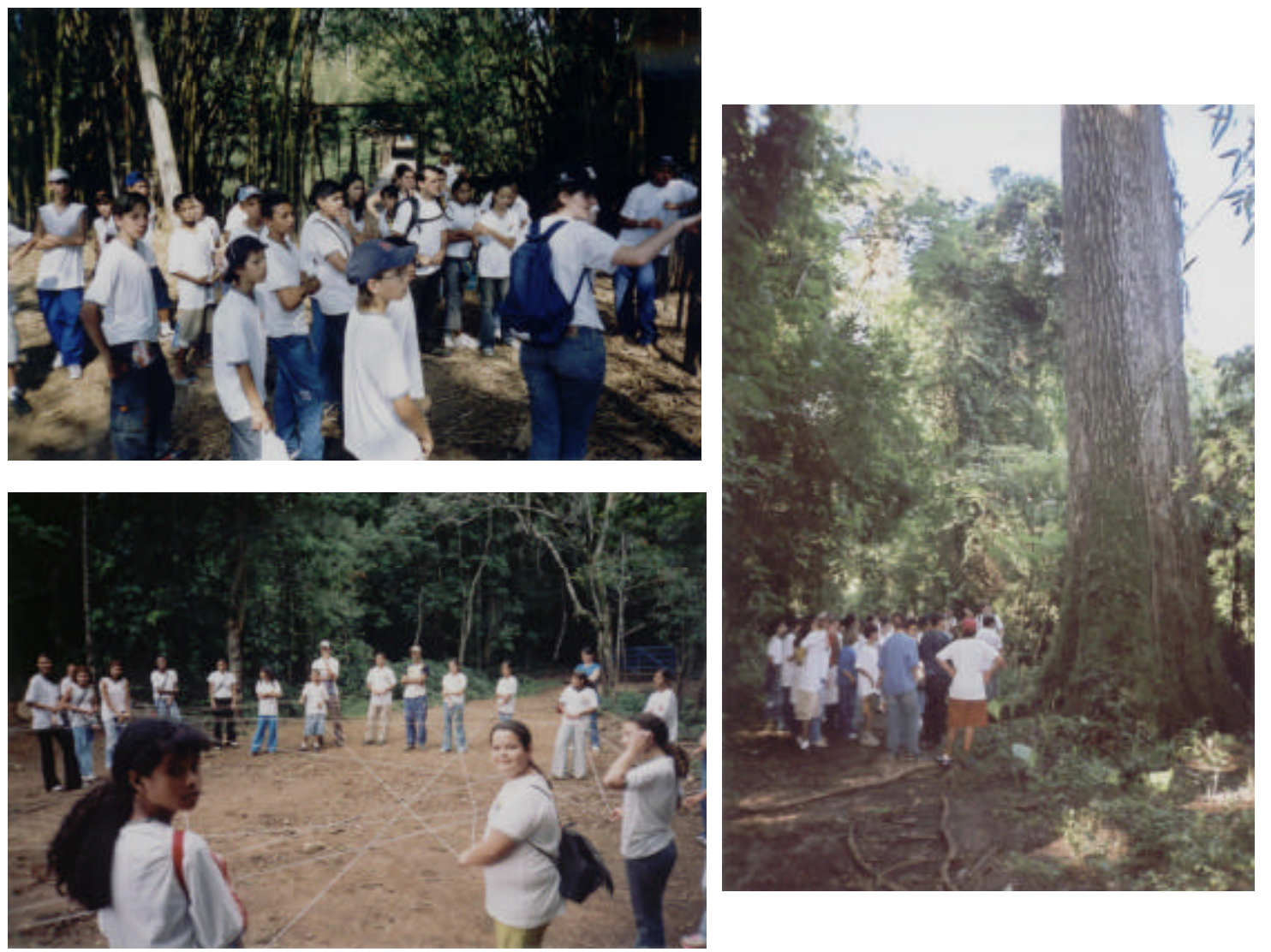

FIGURA 17 - Atividades realizadas durante a visita dos estudantes à trilha da Tubaca. 


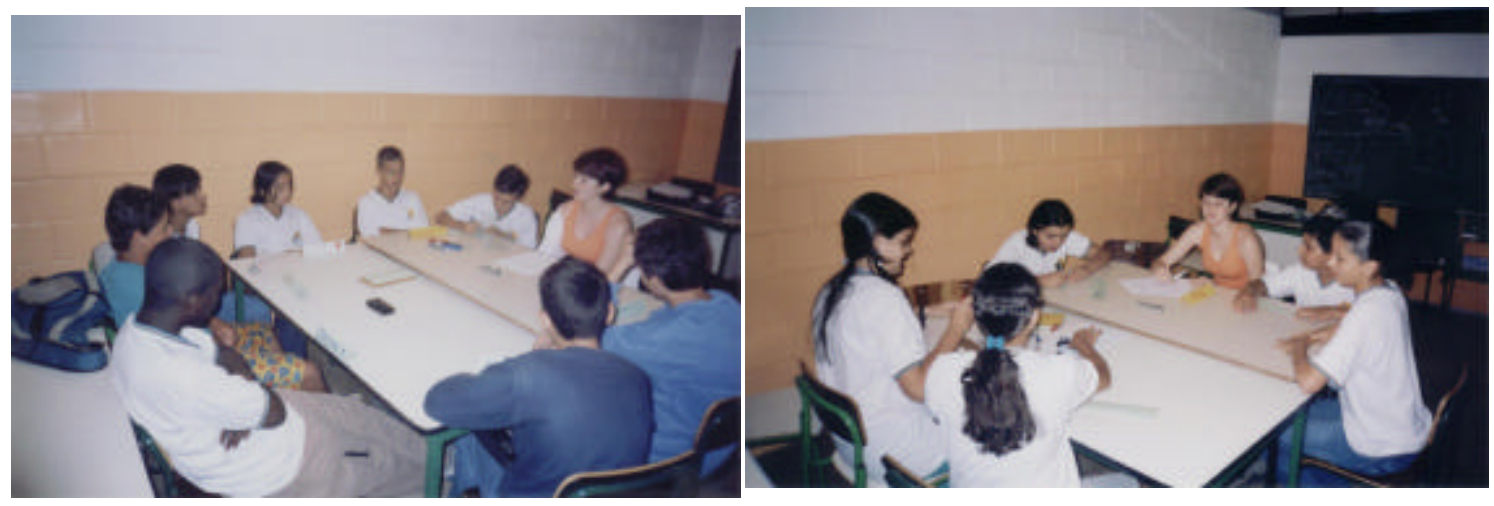

FIGURA 18 - Grupos focais realizados com os estudantes após a visita à trilha da Tubaca.
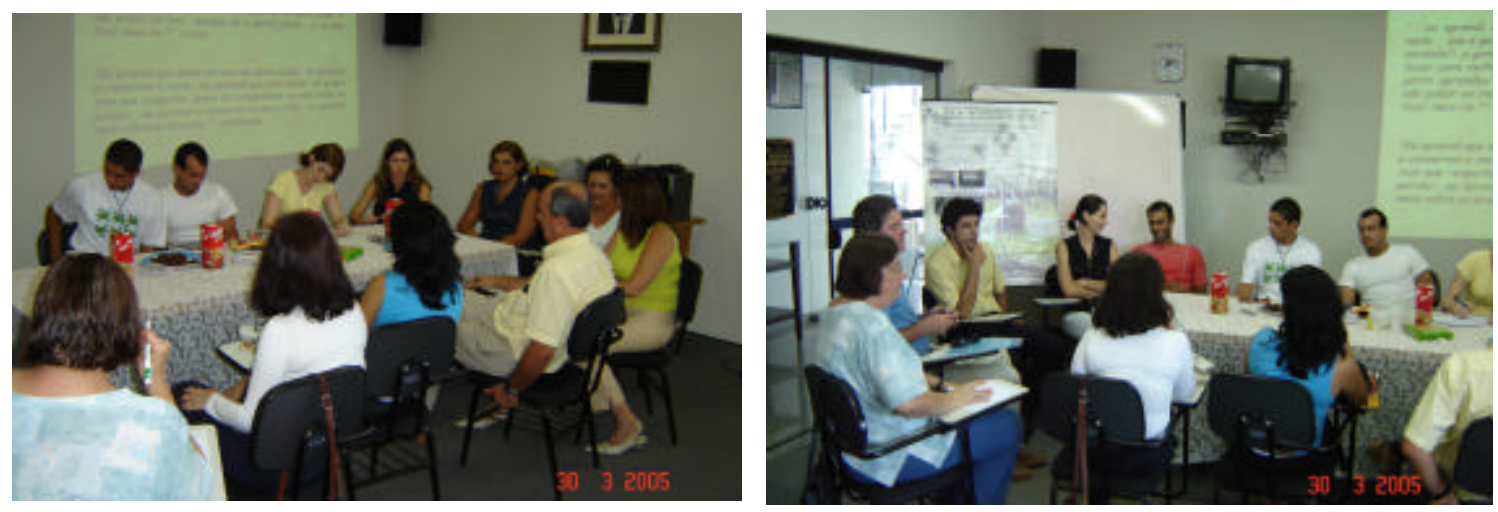

FIGURA 19 - Avaliação da visita à trilha e do processo da pesquisa, conduzida com os participantes. 